UNIVERSIDADE DE SÃO PAULO

HOSPITAL DE REABILITAÇÃO DE ANOMALIAS CRANIOFACIAIS

\title{
SÍNDROMES GENÉTICAS E AMBIENTAIS EM DISTÚRBIOS DA AUDIÇÃO
}

NANCY MIZUE KOKITSU NAKATA

Tese apresentada ao Hospital de Reabilitação de Anomalias Craniofaciais da Universidade de São Paulo, para a obtenção do título de DOUTOR em Ciências da Reabilitação.

Área de concentração: Distúrbios da Comunicação Humana. 


\section{SÍNDROMES GENÉTICAS E AMBIENTAIS EM DISTÚRBIOS DA AUDIÇÃO}

\section{NANCY MIZUE KOKITSU NAKATA}

Orientadora: Profa. Dra. Maria Leine Guion de Almeida

Tese apresentada ao Hospital de Reabilitação de Anomalias Craniofaciais da Universidade de São Paulo, para a obtenção do título de DOUTOR em Ciências da Reabilitação.

Área de concentração: Distúrbios da Comunicação Humana. 


\section{UNIVERSIDADE DE SÃO PAULO \\ HOSPITAL DE REABILITAÇÃO DE ANOMALIAS CRANIOFACIAIS}

Rua Silvio Marchione, 3-20

Caixa Postal: 620

17012-230 - Bauru - SP - Brasil

Telefone: (14) 3235-8000

Profa. Dra. Suely Vilela - Reitora da USP

Prof. Dr. José Alberto de Souza Freitas - Superintendente do HRAC - USP

Autorizo, exclusivamente, para fins acadêmicos e científicos, a reprodução total ou parcial dessa tese.

Nancy Mizue Kokitsu Nakata

Bauru, 11 de agosto de 2006.

\section{Kokitsu-Nakata, Nancy Mizue}

K829s Síndromes genéticas e ambientais em distúrbios da audição. Nancy Mizue kokitsu Nakata. Bauru, 2006.

234p.; il.; $30 \mathrm{~cm}$.

Tese (Doutorado em Ciências da Reabilitação - Área de Concentração: Distúrbios da Comunicação Humana) - HRAC - USP

Orientadora: Profa. Dra. Maria Leine Guion de Almeida

Descritores: 1. Deficiência auditiva 2. Deficiência auditiva sindrômica 3. Múltiplas anomalias 


\section{FOLHA DE APROVAÇÃO}

Tese apresentada e defendida por

\section{NANCY MIZUE KOKITSU NAKATA}

Prof.(a) Dr.(a):

Instituição:

Prof.(a) Dr.(a):

Instituição:

Prof.(a) Dr.(a):

Instituição:

Prof.(a) Dr.(a):

Instituição:

$$
\text { Prof.(a) Dr.(a): }
$$

Instituição:

Profa. Dra. Inge Elly Kiemle Trindade

Presidente da Comissão de Pós-Graduação do HRAC - USP

Data de depósito da tese junto à CPG:

/ 2006 
24 de outubro de 1961

Bauru - SP

$1983-1986$

$1989-1991$

$1991-$

$1997-$

2001

$1998-2000$
Nascimento

Curso de Bacharelado e Licenciatura em

Ciências Biológicas - Universidade

Estadual de Londrina - UEL, Londrina-PR

Bolsista do $\mathrm{CNPq}$, com atuação no

Laboratório de Citogenética do Hospital de

Reabilitação de Anomalias Craniofaciais USP, Bauru-SP

Bióloga do Setor de Genética Clínica do Hospital de Reabilitação de Anomalias Craniofaciais - USP, Bauru-SP

Bióloga responsável pelo Ambulatório de Genética Clínica do Centro de Atendimento aos Distúrbios da Audição, Linguagem e Visão do Hospital de Reabilitação de Anomalias Craniofaciais - USP, Bauru-SP

Professora colaboradora no Curso de Fonoaudiologia da Faculdade de Odontologia de Bauru - FOB - USP

Curso de Pós-Graduação em Ciências, ao nível de Mestrado, pelo Hospital de Reabilitação de Anomalias Craniofaciais Universidade de São Paulo 


\section{DEDICATÓ R I A}

A Deus, nosso criador, pela vida e pela perseverança concedida nos momentos mais difíceis.

Aos meus amados pais, Mitsuo e Néry, exemplo de luta, perseverança, dedicação e amor.

Ao meu querido irmão, Lélio, pelo carinho.

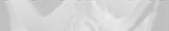

À Natália e Letícia,

filhas minhas... minha vida.

Ao meu grande amor, Milton, por olharmos, juntos, na mesma direção. 


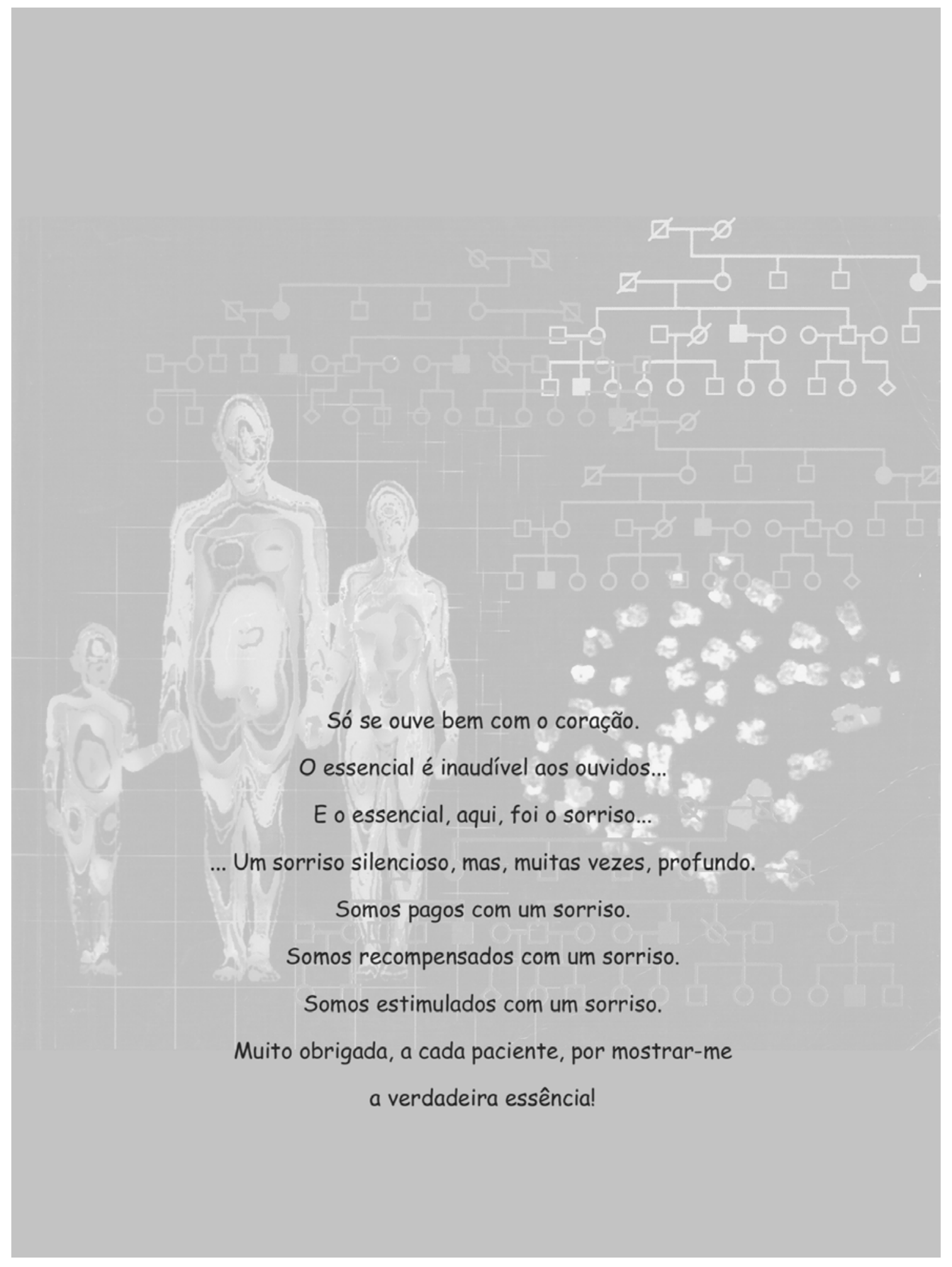




\section{AGRADECIMENTOS}

\section{Crescemos cada vez que alcançamos um objetivo...}

E, o que faz me sentir mais realizada, é saber que não foi uma caminhada solitária, mas sim, uma longa viagem, na qual muitos colaboradores embarcaram durante seu percurso. Valorizo cada um, indistintamente, seja o nosso superintendente, Prof. Dr. José Alberto de Souza Freitas, à mais simples funcionária da limpeza; seja a nossa diretora, Dra. Maria Irene Bachega, aos eficientes circulantes de prontuários;

seja a nossa presidente da Comissão de Pós-Graduação,

Profa. Dra. Inge Elly Kiemle Trindade, aos prestativos secretários da Pós-Graduação; seja a diretora do CEDALVI, Telma Flores Genaro Motti, às atenciosas funcionárias da Central de Agendamento e Arquivo; sejam as fonoaudiólogas do CEDALVI e Centrinho, às simpáticas funcionárias da recepção;

sejam os profissionais do Laboratório de Citogenética, Tânia Yoshico Kamiya e Rubens Matias Rodrigues, aos dedicados jardineiros: sejam as bibliotecárias Ana Ap. Gomes Grigolli e Denise Ap. Giacheti, aos eficientes funcionários da Unidade de Ensino e Pesquisa e Setor de Fotografias ...

Outros colaboradores, talvez por embarcarem logo no início dessa viagem, tiveram uma parcela especial... a minha orientadora

Profa. Dra. Maria Leine Guion de Almeida, que exerceu importante papel nesse trabalho e em minha vida profissional;

o Prof. Dr. Antonio Richieri da Costa, que com suas fundamentais sugestões, sempre foi e será meu mestre:

a Siulan Vendramini Paulovich Pittoli, que com seu carinho e amizade, sempre esteve presente;

a Roseli Maria Zechi Ceide, pela colaboração;

- Dr. Luís Fernando Bérgamo Antunes, pelo auxílio na análise das radiografias; enfim, a todos que, de algum ponto, embarcaram nessa viagem, o meu sincero MUITO OBRIGADA! 


\section{SUMÁRIO}

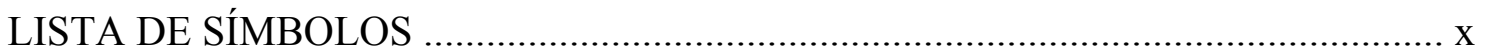

LISTA DE ABREVIATURAS E SIGLAS ….................................................... xi

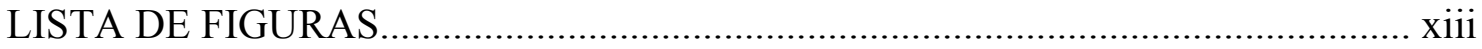

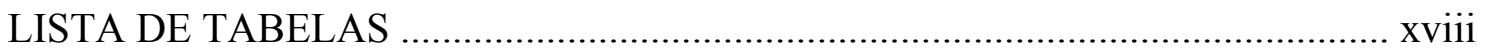

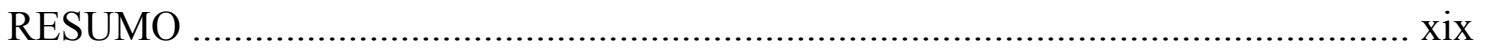

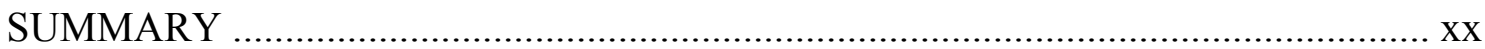

1 INTRODUÇÃO E REVISÃO DE LITERATURA ................................................ 2

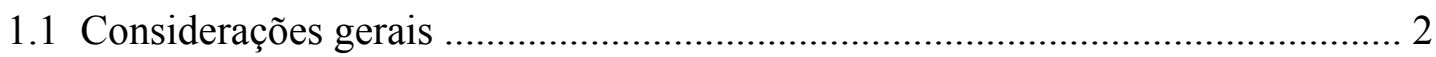

1.2 Deficiência auditiva não sindrômica ............................................................. 3

1.2.1 Classificação da deficiência auditiva ....................................................... 4

1.2.1.1 Quanto ao tipo .......................................................................... 4

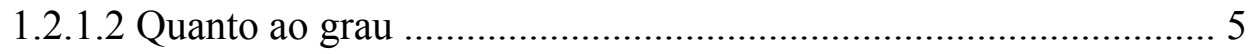

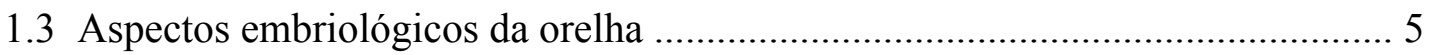

1.4 Deficiência auditiva sindrômica ………….................................................. 8

1.4.1 Aspectos epidemiológicos e etiológicos............................................. 8

1.4.2 Delineamento sindrômico ................................................................12

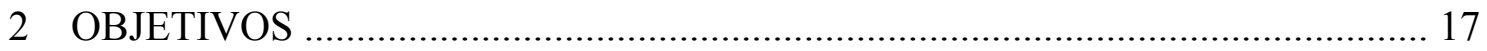

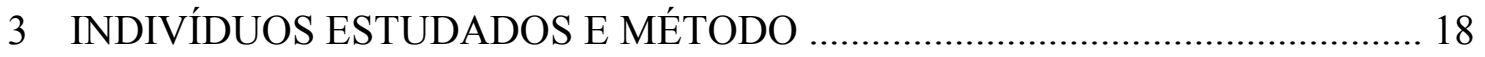

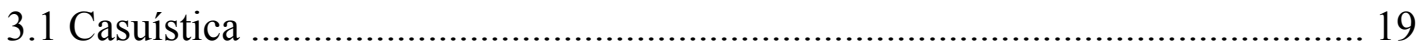

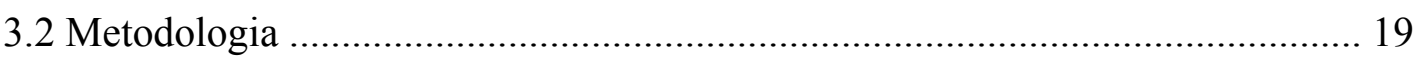

4 RESULTADOS E DISCUSSÃO …................................................................... 23 
4.1 Categoria I: síndromes de etiologia genética ............................................. 30

4.1.1 Síndromes cromossômicas ................................................................ 30

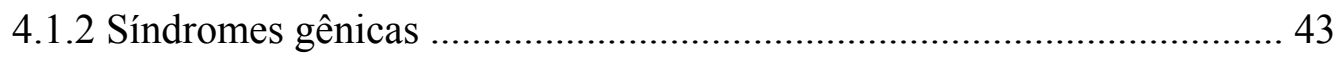

4.1.2.1 Grupo 1: Indivíduos com deficiência auditiva e envolvimento endocrinológico

4.1.2.2 Grupo 2: Indivíduos com deficiência auditiva e envolvimento músculo-esquelético

4.1.2.3 Grupo 3: Indivíduos com deficiência auditiva e envolvimento neurológico

4.1.2.4 Grupo 4: Indivíduos com deficiência auditiva e envolvimento ocular

4.1.2.5 Grupo5: Indivíduos com deficiência auditiva e envolvimento de orelha externa 86

4.1.2.6 Grupo 6: Indivíduos com deficiência auditiva e envolvimento de tegumento

4.1.2.7 Grupo 7: Miscelânea (indivíduos com deficiência auditiva e anomalias diversas)

4.2 Categoria II: síndromes de etiologia ambiental

4.3 Categoria III: síndromes de etiologia gênica e antecedente de fatores ambientais

6 CONCLUSÕES

7 REFERÊNCIAS BIBLIOGRÁFICAS .

8 GLOSSÁRIO

ANEXOS 


\section{LISTA DE SÍMBOLOS}

$\square$ Homem não afetado

Mulher não afetada

- Homem afetado

Mulher afetada

$\square$ Propósito

Propósita

$\diamond$ Sexo desconhecido

$\triangle \varnothing \varnothing$ Indivíduos falecidos

$\square$ Gêmeos monozigóticos

$\square \square$ Gêmeos dizigóticos

$\square \bigcirc$ Casamento consangüíneo 


\section{LISTA DE ABREVIATURAS E SIGLAS}
A - altura
$\mathbf{a}-\operatorname{ano}(\mathrm{s})$

ADNM - atraso no desenvolvimento neuromotor

ADNPM - atraso no desenvolvimento neuropsicomotor

CEDALVI - Centro de Atendimento aos Distúrbios da Audição, Linguagem e Visão

cm - centímetro

d-dia (s)

D - direito (a)

DA - deficiência auditiva

DAC - deficiência auditiva condutiva

DAM - deficiência auditiva mista

DASN - deficiência auditiva sensorioneural

del - deleção

DICE - distância intercantal externa

DICI - distância intercantal interna

$\mathbf{E}$ - esquerdo (a)

EN - estatura ao nascimento

F - feminino

FISH - hibridização in situ com fluorescência

g - grama

G_P_A__ número de gestações, partos e abortos

$\mathbf{h}^{-}$- hetromorfismo

HAD - herança autossômica dominante

HAR - herança autossômica recessiva

HL-X - herança ligada ao cromossomo X

HRAC - Hospital de Reabilitação de Anomalias Craniofaciais

IBGE - Instituto Brasileiro de Geografia e Estatística

IMC - idade materna na concepção

inv - inversão

IPC - idade paterna na concepção 
LDDB - London Dysmorphology Data Base

M - masculino

m - mês/meses

OD - orelha direita

OE - orelha esquerda

OMIM - Online Mendelian Inheritance in Man

OMS - Organização Mundial da Saúde

p - braço curto do cromossomo

$\mathbf{p}$ - percentil

$\mathbf{P}-$ peso

PC - perímetro cefálico

PCR - reação em cadeia da polimerase

PN - peso ao nascimento

POSSUM - Pictures of Standard Syndromes and Undiagnosed Malformations.

Melbourne

$\mathbf{q}$ - braço longo do cromossomo

SIAT - Sistema Nacional de Informações sobre Agentes Teratogênicos

$\mathbf{t}$ - translocação

ter - terminal 


\section{LISTA DE FIGURAS}

Figura 1: Ocorrência de eventos entre a $4^{\mathrm{a}}$ e a $8^{\mathrm{a}}$ semanas do período embrionário ....... 7

Figura 2: Relação das diferentes categorias e grupos com as respectivas síndromes diagnosticadas, o número de orelhas com limiar auditivo rebaixado e o tipo de deficiência auditiva observada ....................................................... 28

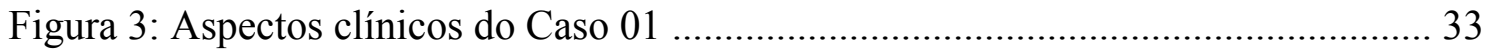

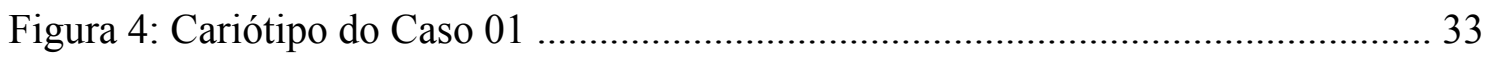

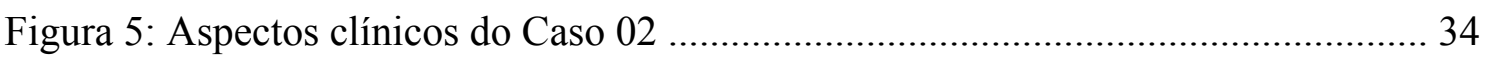

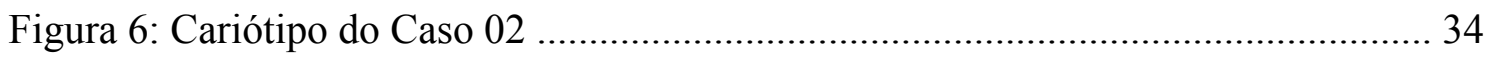

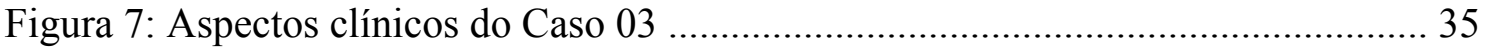

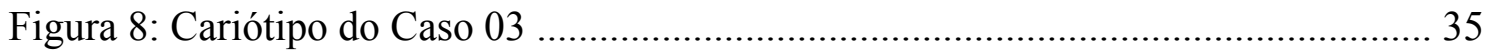

Figura 9: Heredograma da família do Caso 03 ............................................................. 35

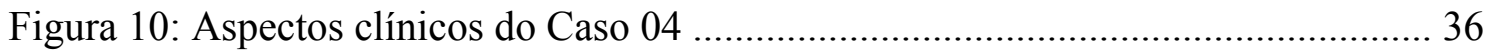

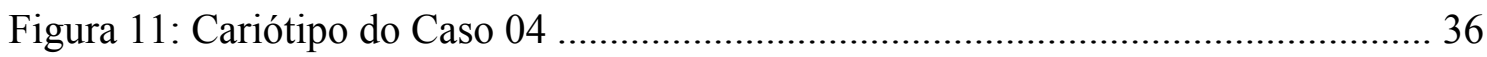

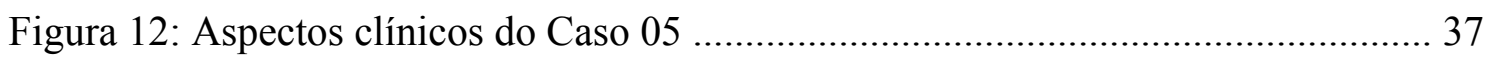

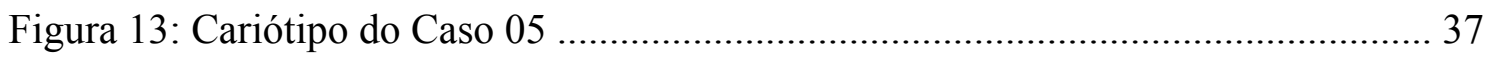

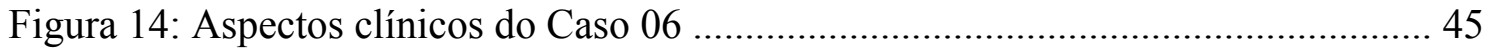

Figura 15: Heredograma da família do Caso 06 .......................................................... 45

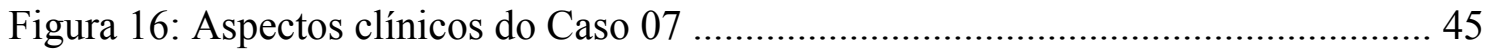

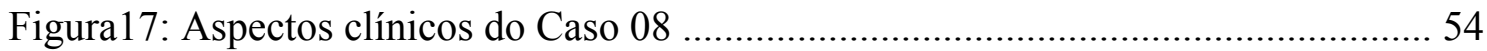

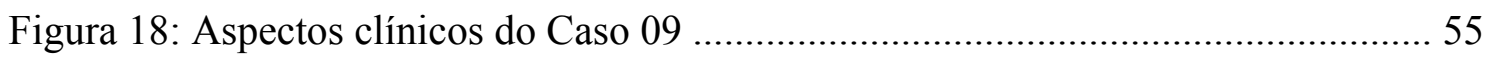

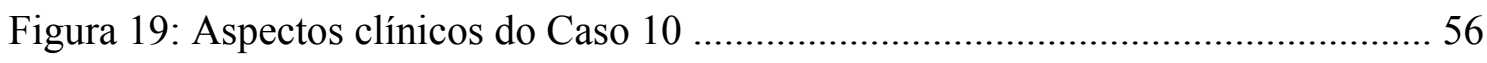

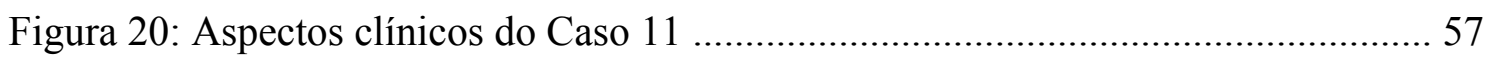

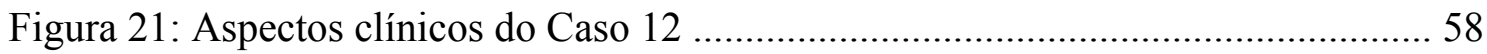

Figura 22: Aspectos clínicos da genitora do Caso 12 …............................................... 58

Figura 23: Heredograma da família do Caso 12 .......................................................... 58

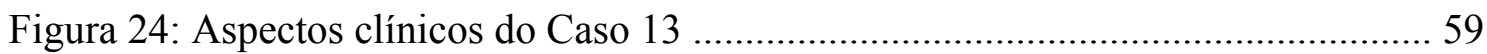

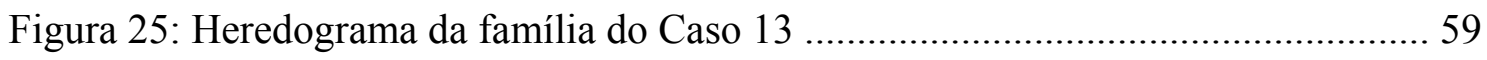

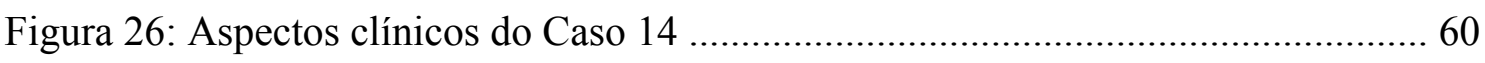

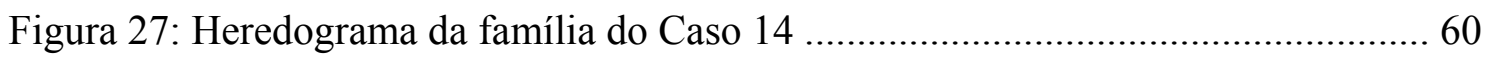

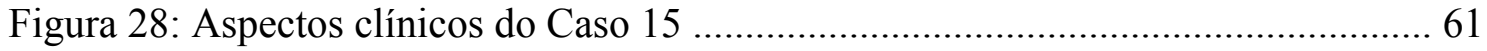


Figura 29: Aspectos clínicos do Caso 16

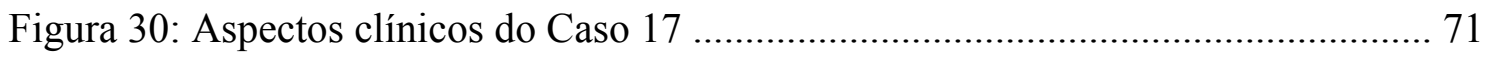

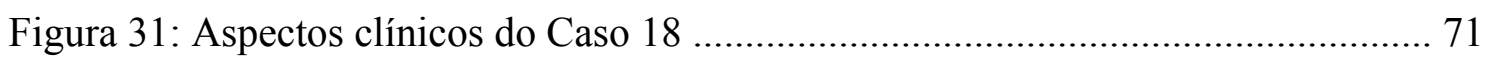

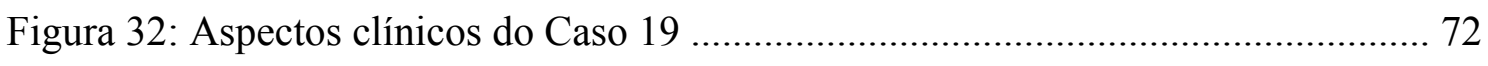

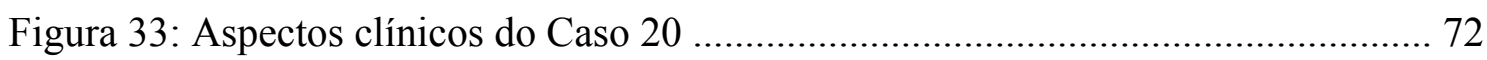

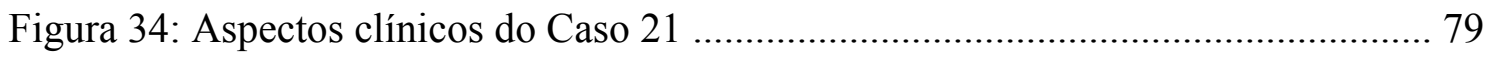

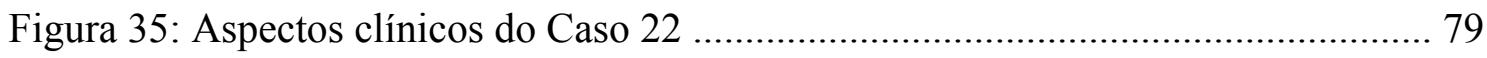

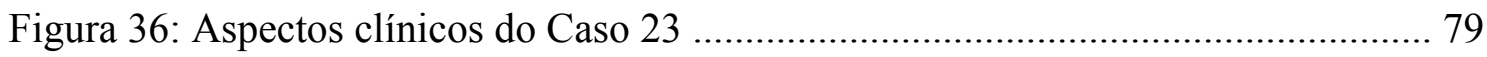

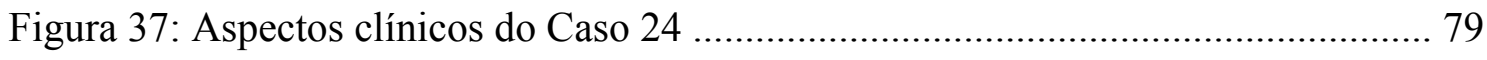

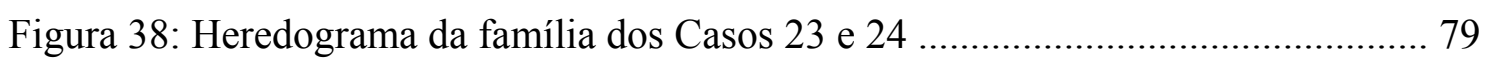

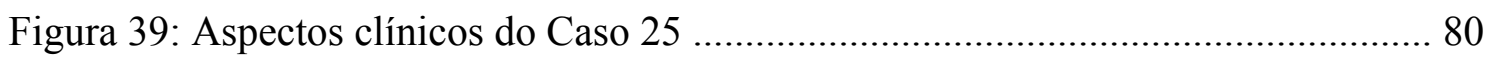

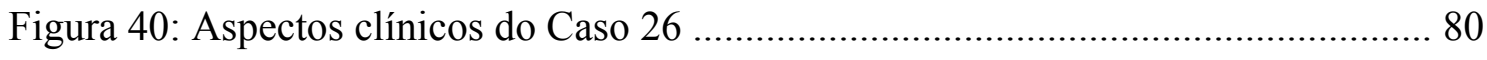

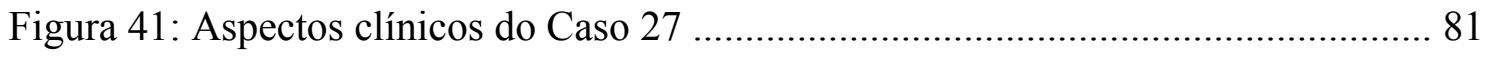

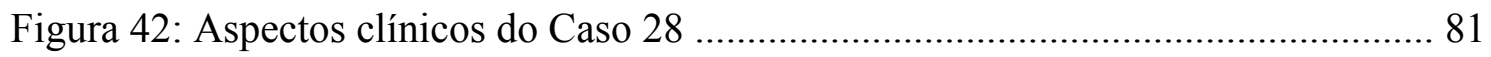

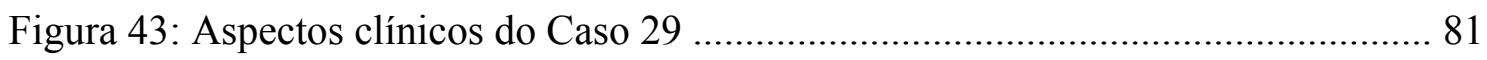

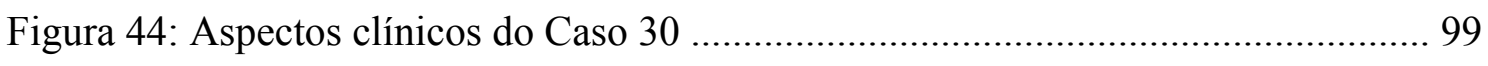

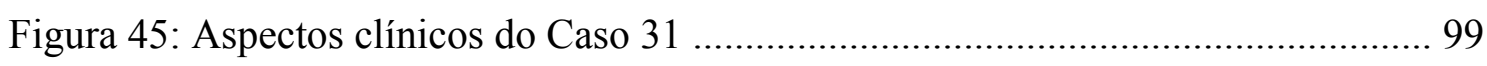

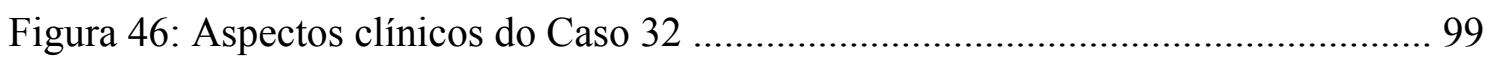

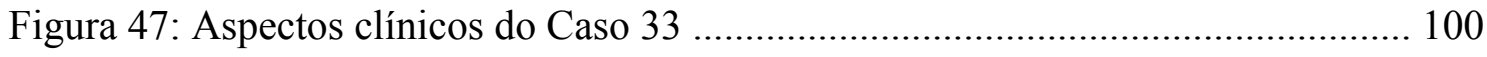

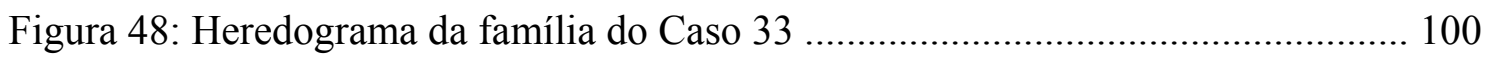

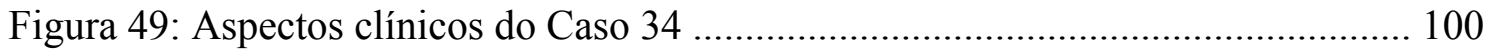

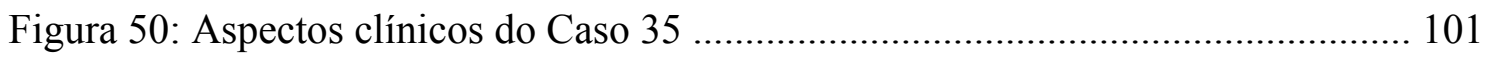

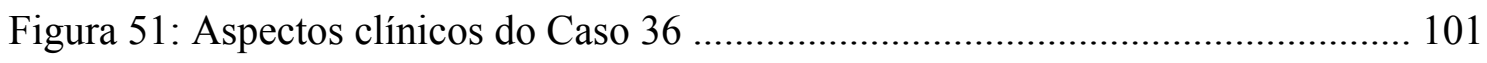

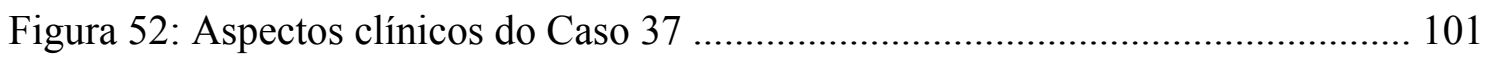

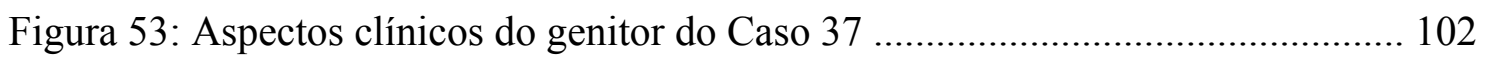

Figura 54: Heredograma da família do Caso 37 ..................................................... 102

Figura 55: Aspectos clínicos e tomográficos do Caso 38 ......................................... 103

Figura 56: Heredograma da família do Caso 38 ..................................................... 103

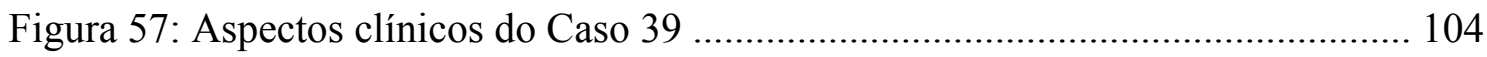

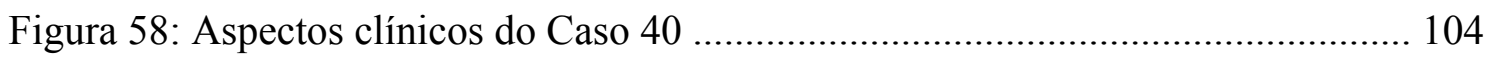

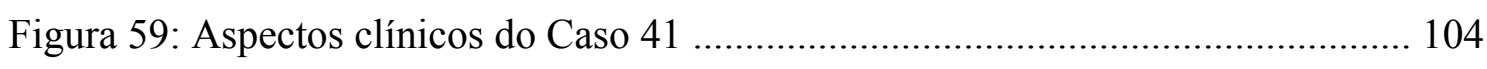

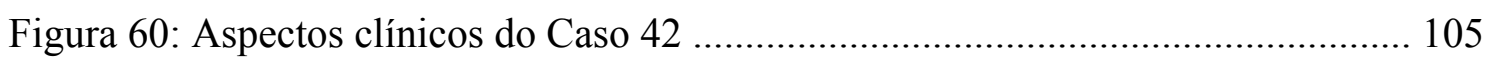

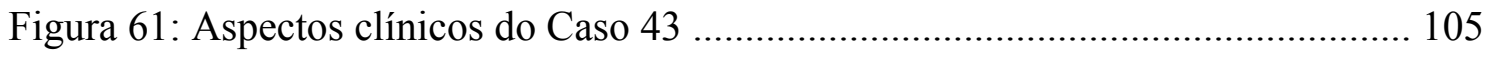




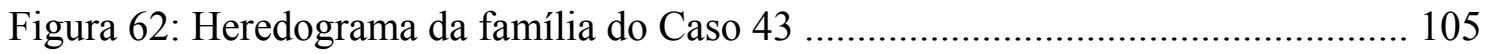

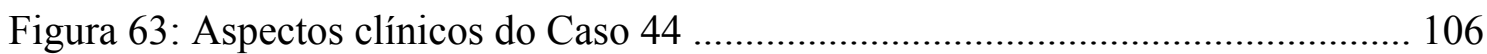

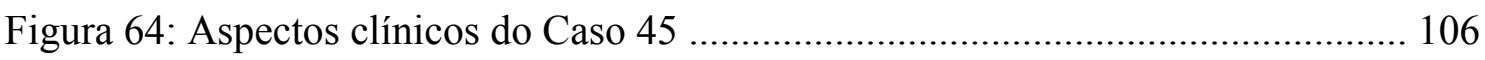

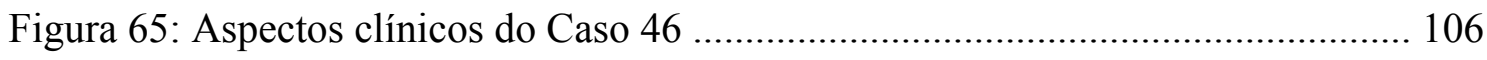

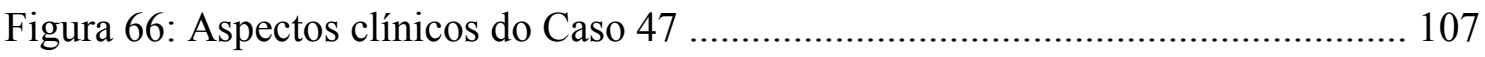

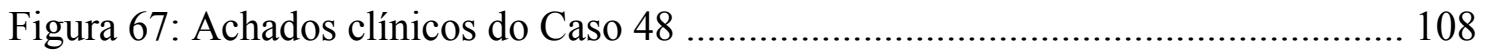

Figura 68: Aspectos clínicos do filho do Caso 48 ..................................................... 108

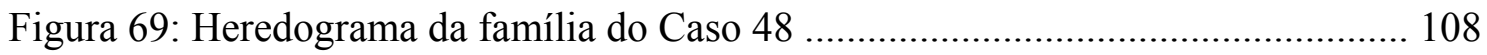

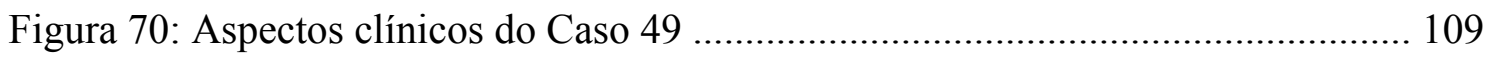

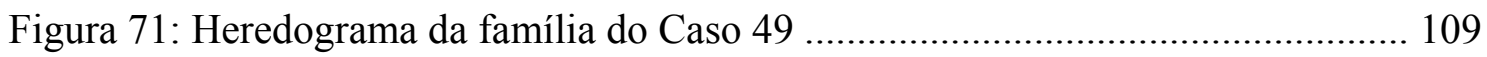

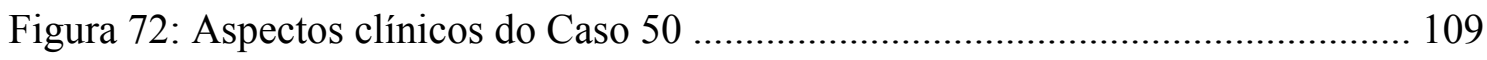

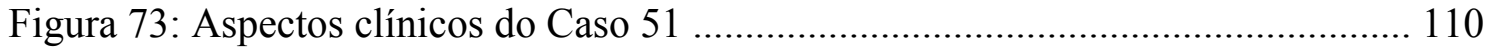

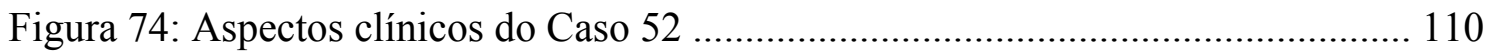

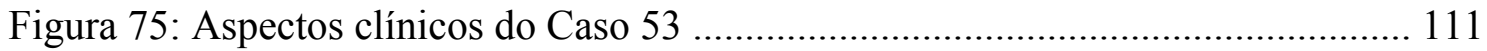

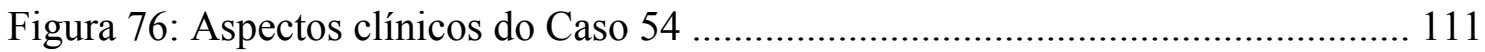

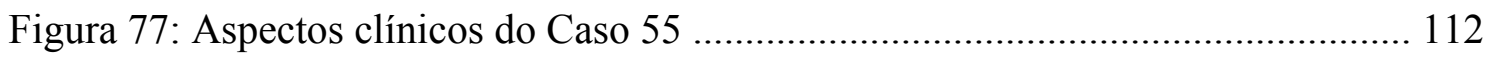

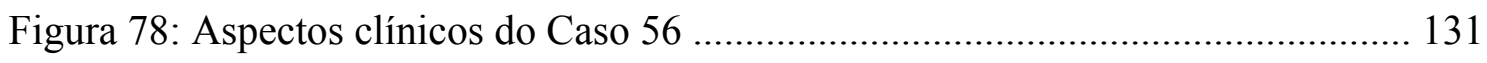

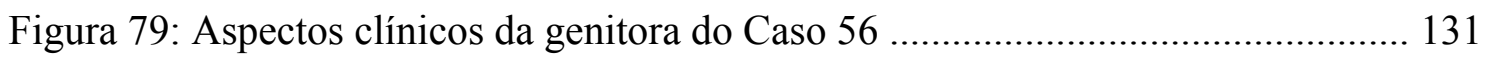

Figura 80: Heredograma da família do Caso 56 ..................................................... 131

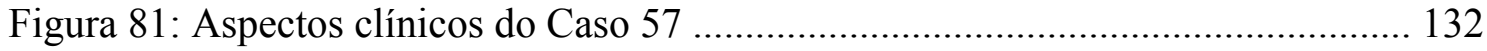

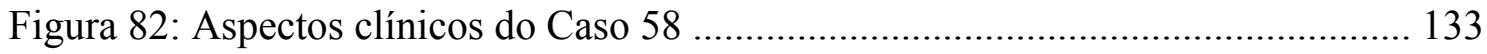

Figura 83: Heredograma da família do Caso 58 ........................................................ 133

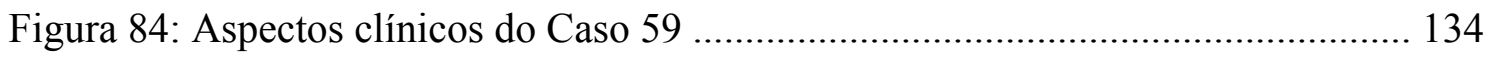

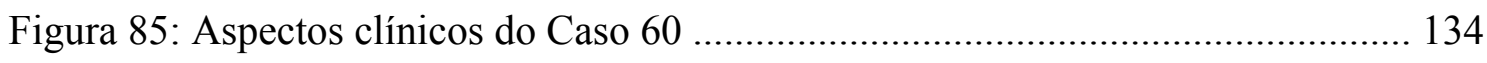

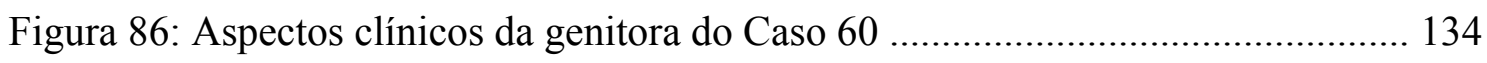

Figura 87: Heredograma da família do Caso 60 ..................................................... 134

Figura 88: Aspectos clínicos do Caso 61 .................................................................... 135

Figura 89: Aspectos clínicos da genitora do Caso 61 .................................................. 135

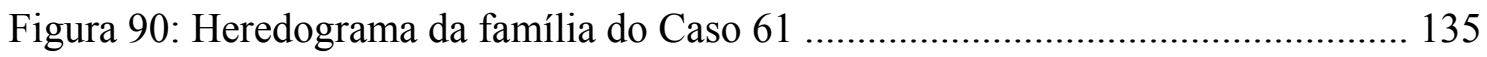

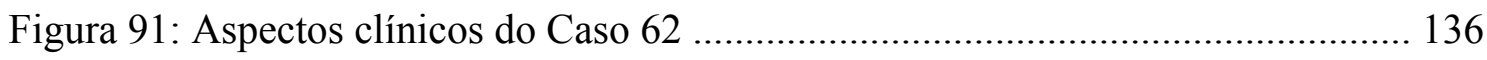

Figura 92: Aspectos clínicos da genitora do Caso 62 .............................................. 136

Figura 93: Heredograma da família do Caso 62 ..................................................... 136

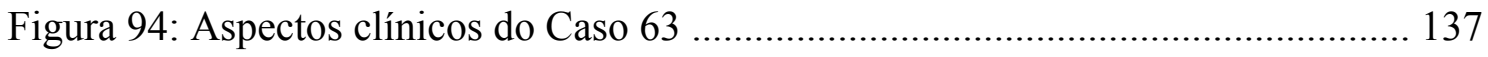




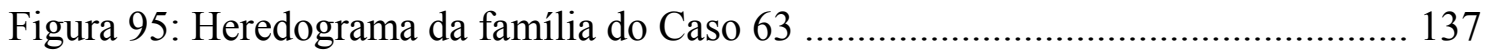

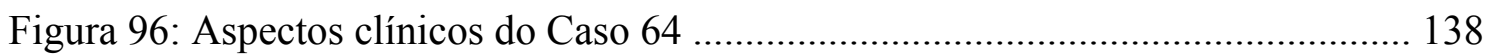

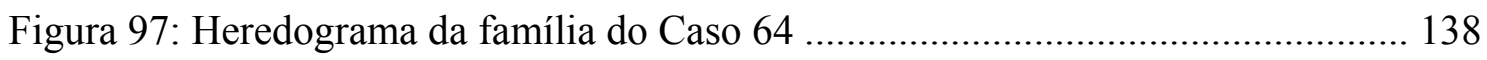

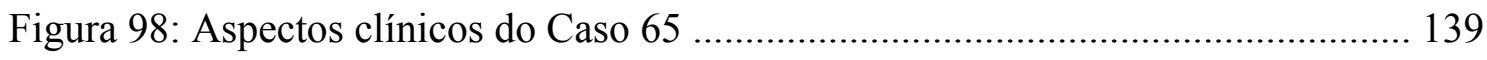

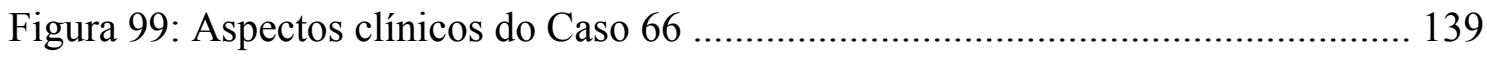

Figura 100: Heredograma da família do Caso 66 ....................................................... 139

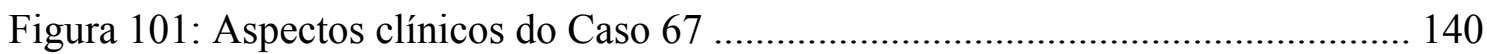

Figura 102: Heredograma da família do Caso 67 ................................................... 140

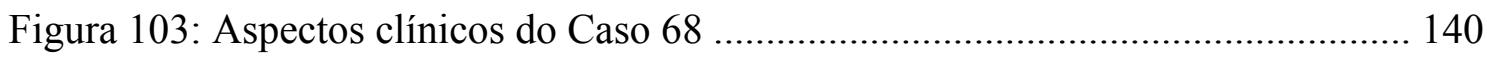

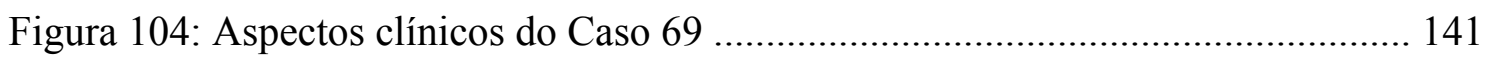

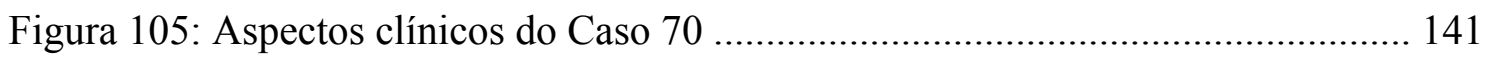

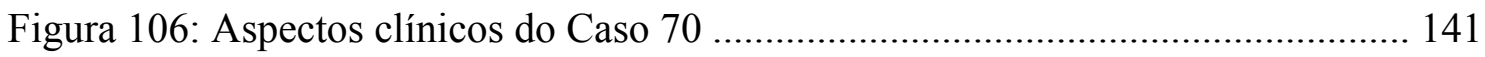

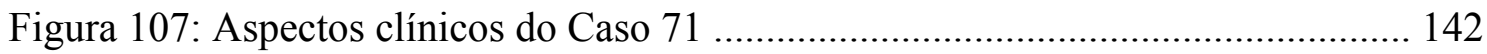

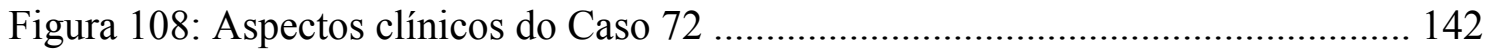

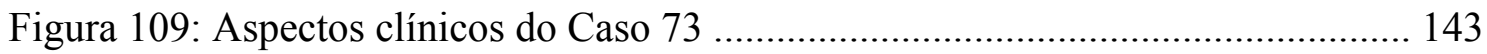

Figura 110: Heredograma da família do Caso 73 ................................................... 143

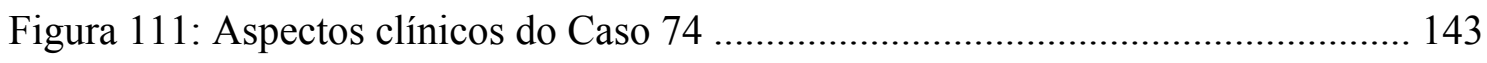

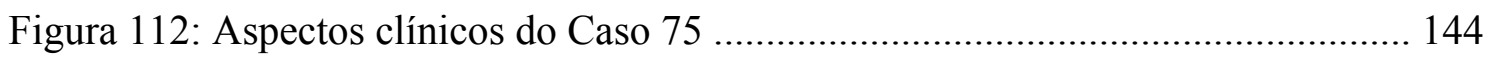

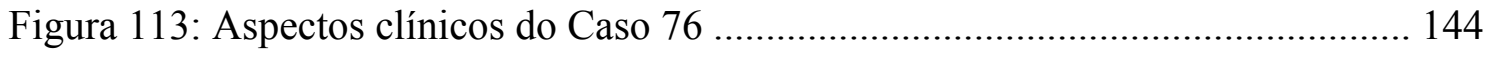

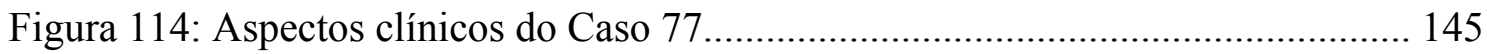

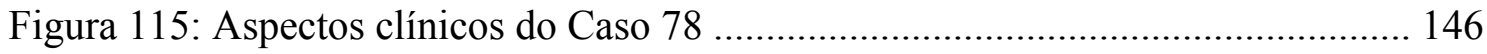

Figura 116: Heredograma da família do Caso 78 ........................................................ 146

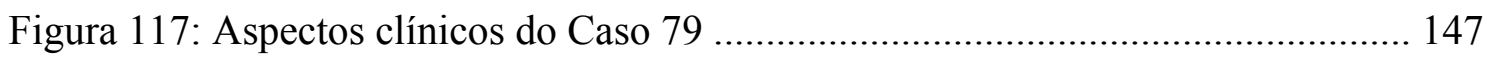

Figura 118: Aspectos clínicos do genitor do Caso 79 ............................................... 147

Figura 119: Aspectos clínicos da irmã do Caso 79 ................................................... 147

Figura 120: Heredograma da família do Caso 79 ................................................... 148

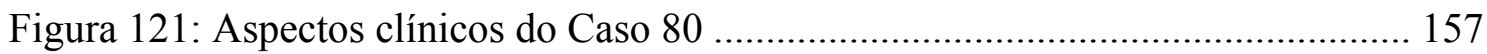

Figura 122: Aspectos clínicos da genitora do Caso 80 ............................................... 157

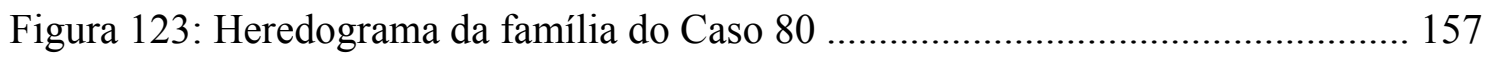

Figura 124: Aspectos clínicos e radiológicos do Caso 81 ......................................... 158

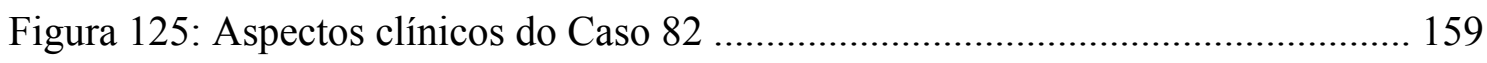

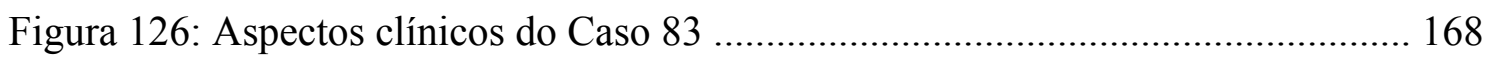

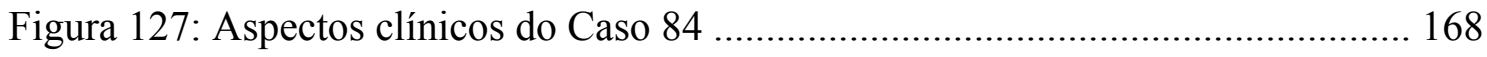




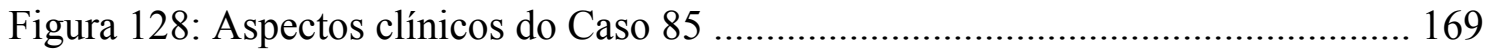

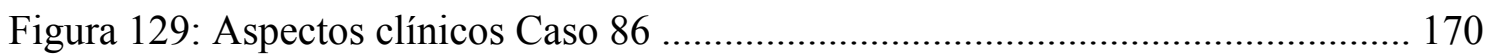

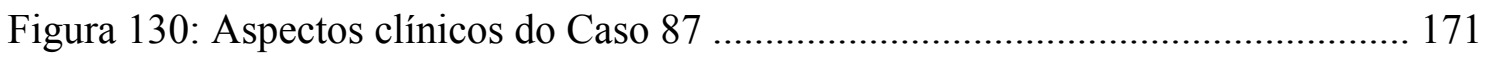

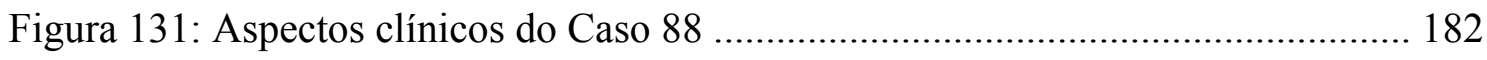

Figura 132: Aspectos clínicos do Caso 89 .............................................................. 182

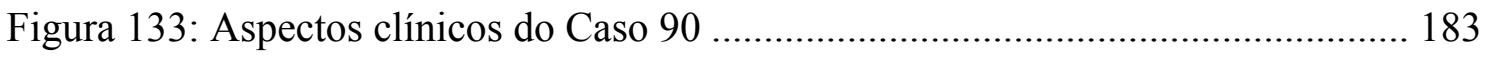

Figura 134: Heredograma da família do Caso 90 ..................................................... 183

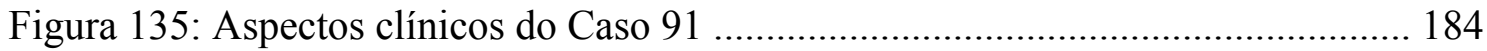

Figura 136: Aspectos clínicos do Caso 92 …............................................................ 185

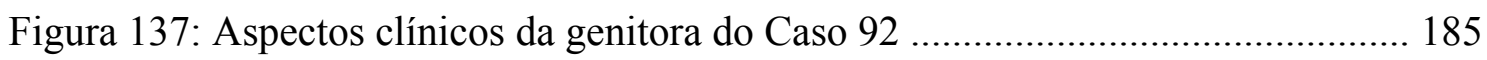

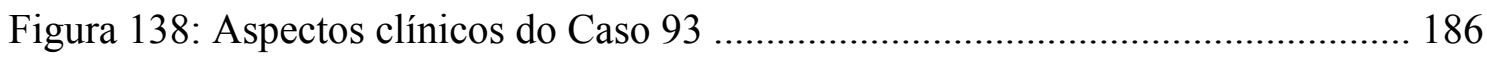




\section{LISTA DE TABELAS}

Tabela 1: Regiões candidatas e/ou genes identificados, responsáveis por diversas síndromes com deficiência auditiva ............................................................ 10

Tabela 2: Comparação geral de malformações, deformações e disrupções .................. 13

Tabela 3: Síndromes gênicas e cromossômicas encontradas na presente casuística ..... 25

Tabela 4: Antecedentes gestacionais relevantes da presente casuística ...................... 26

Tabela 5: Fatores de risco, para deficiência auditiva, observados nos indivíduos da presente casuística

Tabela 6: Dados dos indivíduos com deficiência auditiva e anormalidade

cromossômica 31

Tabela 7: Dados dos indivíduos com deficiência auditiva e envolvimento endocrinológico 44

Tabela 8: Dados dos indivíduos com deficiência auditiva e envolvimento músculo-esquelético

Tabela 9: Dados dos indivíduos com deficiência auditiva e envolvimento neurológico

Tabela 10: Dados dos indivíduos com deficiência auditiva e envolvimento ocular 76

Tabela 11: Dados dos indivíduos com deficiência auditiva e envolvimento de orelha externa

Tabela 12: Dados dos indivíduos com deficiência auditiva e envolvimento de tegumento

Tabela 13: Dados dos indivíduos com deficiência auditiva e anomalias diversas (miscelânea)

Tabela 14: Dados dos indivíduos com síndrome de etiologia ambiental 164

Tabela 15: Dados dos indivíduos com síndrome de etiologia gênica e antecedente de fatores ambientais 


\section{RESUMO}

KOKITSU-NAKATA, NM. Síndromes genéticas e ambientais em distúrbios da audição [tese]. Bauru: Hospital de Reabilitação de Anomalias Craniofaciais, Universidade de São Paulo; 2006.

Objetivos: estabelecer o diagnóstico de uma amostra de indivíduos com deficiência auditiva (DA) e comprometimento de outras estruturas anatômicas e/ou sistemas fisiológicos, cadastrados no CEDALVI/HRAC-USP-Bauru; verificar possíveis fatores etiológicos envolvidos e investigar possível correlação do tipo de DA com as diferentes síndromes encontradas.

Local: Serviço de Genética Clínica do CEDALVI/HRAC-USP, Bauru-SP.

Participantes: 93 indivíduos com DA e comprometimento de outras estruturas anatômicas e/ou sistemas fisiológicos.

Intervenções: Avaliação genética-clínica; estudo citogenético; avaliações radiológica, oftalmológica, otorrinolaringológica, audiológica e outras.

Resultados: Dos 93 indivíduos, 51 eram do sexo masculino e 42, do feminino. Recorrência familial foi observada em 31 casos e, consangüinidade parental em 8 . Na amostra, 25 síndromes gênicas conhecidas, 5 síndromes cromossômicas, 5 quadros de etiologia ambiental e 2 quadros de etiologia heterogênea foram estabelecidos em 87 indivíduos. Em 1 caso, não foi possível definir entre 2 condições gênicas e em 5, não foi possível se chegar a um diagnóstico.

Conclusões: a casuística se compôs de síndromes etiologicamente heterogêneas, com maior freqüência de etiologia genética; o tipo de DA nas síndromes gênicas foi condizente com o quadro diagnosticado; 3 indivíduos apresentaram síndromes ambientais clássicas, com diferentes tipos de DA; 2 indivíduos apresentaram quadro clínico, possivelmente decorrente de efeito teratogênico; implicação direta de fatores de risco para DA, na etiologia dessa, nos indivíduos com síndromes gênicas conhecidas sem DA; 1 caso, possivelmente, representa uma síndrome nova de padrão único, de etiologia desconhecida; o aconselhamento genético está na dependência da fase em que se encontra o processo de delineamento das diferentes condições estabelecidas.

Descritores: Deficiência auditiva, deficiência auditiva sindrômica, múltiplas anomalias 


\section{SUMMARY}

KOKITSU-NAKATA, NM. Genetic and environmental syndromes in hearing loss disturbance [thesis]. Bauru: Hospital of Rehabilitation of Craniofacial Anomalies, University of São Paulo; 2006.

Objectives: The purposes of this study were to establish the diagnostic of the individuals with hearing loss and presenting other additional anatomic structures and/or physiologic systems involvement, recorded in the CEDALVI/HRAC-USP-Bauru; to verify possible etiologic factors involved and to investigate a possible correlation of the hearing loss type with the different diagnosis syndromes.

Setting: Clinical genetic service of the CEDALVI/HRAC-USP, Bauru-SP.

Participants: The sample was comprised of 93 individuals with hearing loss and involvement of other anatomic structures and/or physiologic systems.

Interventions: Clinical genetic evaluation; cytogenetic study; radiological, ophtalmological, othorinolaryngological, audiologycal evaluation, etc.

Results: From the total of the sample, 51 were male and 42 were female. Familial recurrence was observed in 31 cases and parental consanguinity in 8 . In the present sample, 25 known genic syndromes, 5 chromosomal syndromes, 5 environmental conditions, and 2 heterogeneous conditions were established in 87 individuals. The diagnosis was not established in 5 individuals and in 1 case it was not possible to define between 2 genic conditions.

Conclusions: The casuistic was composed of etiologically heterogeneous syndromes with greater frequency of genetic etiology; the type of hearing loss in the genic syndromes was concordant with the diagnosed condition; 3 individuals presented classic environmental syndromes with different types of hearing loss; 2 individuals presented clinical picture, possibly due to teratogenic effect; hearing impairment related to risk factors of the hearing loss in the individuals with known genic syndromes without hearing loss; probable a new unique-pattern syndrome, of unknown etiology in 1 case; the genetic counseling will depend on the step of delineation process of the different diagnosed condition.

Key words: Hearing loss, syndromic hearing loss, multiples anomalies. 


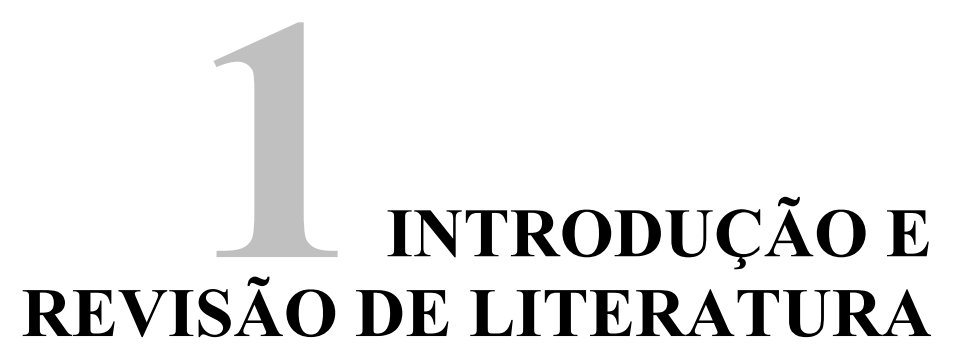




\section{INTRODUÇÃO E REVISÃO DE LITERATURA}

\subsection{Considerações gerais}

As anomalias congênitas são as maiores causas de mortalidade infantil e morbidade na infância, afetando $2 \%-3 \%$ dos bebês. $\mathrm{O}$ nascimento de uma criança com malformações, geralmente, causa um impacto à sociedade e à família. Como tentativa de explicar a causa e o significado de cada anormalidade, as pessoas criam "conceitos próprios”, freqüentemente relacionados a histórias folclóricas do passado, incorporadas aos seus valores culturais (Warkany, 1971). Na Babilônia antiga, o nascimento de um bebê malformado, era interpretado como um "sinal dos deuses", predizendo eventos futuros de grande conseqüência. Código, definindo significado para o bem ou para o mal, de cada uma das muitas anomalias, foi elaborado pelos sacerdotes. A criança, a família ou até mesmo a nação inteira poderia ser afetada dependendo da natureza da anormalidade. Esta idéia persistiu até o tempo da Roma antiga. O Museu Britânico, em Londres, guarda uma série de tábuas, com inscrições que datam de 4.000 anos, as quais contêm a descrição de 65 anomalias com seus respectivos significados (Warkany, 1971). Na Idade Média, o conceito de intervenção divina foi alterado por estudos religiosos, que pregavam o conceito de culpa pessoal. O nascimento de uma criança, com anomalia congênita, era creditado a pecados cometidos pelos pais, geralmente, pela mãe (Aase, 1990). Com a chegada da Idade Moderna, houve a tentativa de se explicar a causa do nascimento de crianças com anormalidades, através de fatos ocorridos durante a gestação. O conceito de agentes externos agindo sobre a formação do feto durante a gestação, denominou-se teratogênese. Muitas dessas convicções foram derrubadas, mas até os dias atuais, pais e familiares relacionam o nascimento de crianças com defeitos congênitos a conceitos do passado.

Dos 2 a 3\% dos recém-nascidos com defeitos congênitos, aproximadamente, $1 \%$ apresenta múltiplas anomalias, podendo, ou não, caracterizar uma síndrome. Dentre essas, muitas apresentam deficiência auditiva, como característica importante do quadro clínico. A função da audição é fundamental, na medida em que fornece informações essenciais para a integração das pessoas no mundo físico e social, possibilitando o "controle" do ambiente. As crianças deficientes 
auditivas apresentam seu desenvolvimento global alterado já que, sem as sensações auditivas, não há interação do indivíduo com o meio. A integridade do sistema auditivo é essencial para a aquisição da fala e, portanto, para o desenvolvimento da linguagem e cognição.

Embora a deficiência auditiva, na maioria dos casos, ocorra de forma isolada, trabalhos de Cohen Jr e Gorlin (1995) mostram que cerca de 30\% dessa população apresenta outras anomalias associadas, constituindo, ou não, síndromes. A alta porcentagem e a heterogeneidade da deficiência auditiva associada a outras anomalias dão uma idéia geral da complexidade do estudo sindromológico destas condições. A identificação precisa de cada síndrome malformativa requer um conhecimento especializado que, em geral, depende de um conjunto de profissionais de uma equipe multidisciplinar.

O Centro de Atendimento aos Distúrbios da Audição, Linguagem e Visão (CEDALVI) - Hospital de Reabilitação de Anomalias Craniofaciais-USP-Bauru (HRAC-USP-Bauru), desenvolvendo seu trabalho desde 1987, conta, atualmente, com mais de 22.000 pacientes cadastrados. Cerca de $85 \%$ desse total apresenta perda auditiva. Desse universo, envolvimento de outras estruturas anatômicas e/ou sistemas fisiológicos, ocorre em cerca de $20 \%$ desses casos.

$\mathrm{O}$ número de pacientes com deficiência auditiva, cadastrados no CEDALVI/HRAC-USP-Bauru, o elevado número de indivíduos com múltiplas anomalias nessa população, a escassez de estudos direcionados aos indivíduos com deficiência auditiva sindrômica e, ainda, a importância diagnóstica no que se refere ao prognóstico, abordagem terapêutica, prevenção e aconselhamento genético, para essa população, mostram a relevância do presente trabalho.

\subsection{Deficiência auditiva não sindrômica}

Entende-se por deficiência auditiva não sindrômica, aquela perda auditiva isolada, ou seja, sem associação a outras anomalias congênitas. A deficiência auditiva isolada, de acordo com a Organização Mundial da Saúde (OMS), afeta cerca de 10\% da população mundial (Bento 1996). Segundo dados do Censo 2000 do Instituto Brasileiro de Geografia e Estatística (IBGE), são 24,5 milhões de brasileiros com algum 
tipo de deficiência auditiva (cerca de $15 \%$ da população). O diagnóstico etiológico nem sempre é fácil de ser estabelecido em função de sua grande heterogeneidade. Assim, são comuns as referências de que cerca de 25 a 50\% das crianças não tenham determinada a etiologia da deficiência auditiva (Dias e Andréa 1990, Van Rijin 1991, Kokitsu-Nakata et al 2004). Causas infecciosas são relativamente freqüentes, principalmente em países em desenvolvimento; porém, a etiologia genética tende a se tornar mais importante na medida em que ocorre melhoria das condições de saúde pública (Lubianca Neto e Pereira 1999). O conhecimento da genética da perda auditiva avançou rapidamente durante a última década do século XX. Vários genes responsáveis pela audição normal foram identificados e numerosos outros foram localizados em regiões cromossômicas específicas (Hone e Smith 2001). De acordo com levantamento realizado na Homepage - van Camp e Smith (July 16, 2006), foram descritos 21 genes responsáveis pela perda auditiva não sindrômica de transmissão autossômica dominante; 23 genes com transmissão autossômica recessiva, 1 gene com transmissão ligada ao cromossomo X e 7 genes com transmissão mitocondrial.

\subsubsection{Classificação da deficiência auditiva}

\subsubsection{Quanto ao tipo}

- Deficiência auditiva condutiva: qualquer interferência na transmissão do som desde o conduto auditivo externo até a orelha interna (cóclea). A grande maioria das deficiências auditivas condutivas pode ser corrigida através de tratamento clínico ou cirúrgico.

- Deficiência auditiva sensorioneural: ocorre quando há uma impossibilidade de recepção do som por lesão das células ciliadas da cóclea ou do nervo auditivo. Esse tipo de deficiência auditiva é irreversível.

- Deficiência auditiva mista: ocorre quando há uma alteração na condução do som até o órgão terminal sensorial associado à lesão do órgão sensorial ou do nervo auditivo.

- Deficiência auditiva central: decorre de alterações nos mecanismos de processamento da informação sonora no tronco cerebral (sistema nervoso central). 


\subsubsection{Quanto ao grau}

Os níveis de limiares utilizados para caracterizar os graus de severidade da deficiência auditiva podem ter algumas variações entre os diferentes autores. Segundo classificação baseada na OMS (2006), considera-se:

- Audição normal: limiares entre 0 a $25 \mathrm{dBNA}$

- Deficiência auditiva leve: limiares entre 26 a 40 dBNA

- Deficiência auditiva moderada: limiares entre 41 a 60 dBNA

- Deficiência auditiva severa: limiares entre 61 a 80 dBNA

- Deficiência auditiva profunda: limiares acima de $81 \mathrm{dBNA}$

\subsection{Aspectos embriológicos da orelha}

A orelha passa por seu processo completo de formação entre a $3^{\mathrm{a}}$ e a $37^{\mathrm{a}}$ semana de gestação, apresentando três origens embriológicas distintas, de acordo com a parte que se considera.

A orelha externa, cuja função é recolher o som, origina-se da parte dorsal do primeiro sulco faríngeo; já a orelha média, que desempenha um papel de condutor das vibrações sonoras, desenvolve-se da primeira bolsa faríngea. A orelha interna, que transforma a energia mecânica das vibrações sonoras em impulsos nervosos, forma-se de uma vesícula resultante da invaginação do ectoderma que recobre o rombencéfalo.

A orelha interna forma-se entre a $3^{\mathrm{a}}$ e a $21^{\mathrm{a}}$ semana embrionária, através de um espessamento do ectoderma que recobre as partes laterais da futura cabeça do embrião, o placódio ótico que, posteriormente, invagina-se no mesênquima subjacente, originando a vesícula ótica. Essa vesícula epitelial sofre uma série de transformações complexas: 1) um componente ventral é diferenciado e, gradualmente, dará origem ao sáculo e ao canal coclear, o qual transformar-se-á na cóclea; 2) a parte dorsal formará os canais semicirculares, utrículo, ducto e saco endolinfático. As estruturas epiteliais acima mencionadas formarão o labirinto membranoso, o qual contêm a endolinfa. $O$ mesênquima que reveste o labirinto membranoso transforma-se, gradualmente, em cartilagem, a qual é substituída por tecido ósseo, formando o labirinto ósseo. Entre esses dois labirintos, permanece um estreito espaço cheio de líquido, a perilinfa. 
A orelha média, a qual se forma entre a $3^{\mathrm{a}}$ e a $37^{\mathrm{a}}$ semana embrionária, origina-se de uma evaginação dorsal da primeira bolsa faríngea (origem endodérmica). Essa evaginação dilata-se na sua parte mais distal, dando origem à cavidade timpânica primitiva. A parte proximal que não se dilata, formará a trompa de Eustáquio ou tuba auditiva. No local onde a trompa desemboca na faringe, desenvolve-se tecido linfóide, formando a tonsila tubária que, quando inflamada, leva muitas vezes a uma oclusão da trompa, com infecção da orelha média (otite média). Os ossículos da orelha formam-se à custa das partes dorsais do primeiro e segundo arcos branquiais. São estruturas cartilaginosas que, posteriormente, ossificam-se. Esses ossículos permanecem imersos, por longo tempo, no mesênquima circundante. Só no último mês da vida fetal, o mesênquima desaparece, ficando os ossículos individualizados. Nessa ocasião, o espaço previamente ocupado pelo mesênquima é invadido pelo epitélio que recobre o divertículo da primeira bolsa faríngea, formando a cavidade timpânica. Essa e os ossículos do ouvido ficam, conseqüentemente, recobertos por epitélio.

A orelha externa se forma entre a $4^{\mathrm{a}}$ e a $30^{\mathrm{a}}$ semana do período embrionário, quando o primeiro sulco faríngeo dá origem, na sua parte dorsal, ao meato auditivo externo. Este se aprofunda, adquire a forma de funil e fica revestido por epitélio de origem ectodérmica; o mesmo epitélio revestirá a superfície externa do tímpano, o qual é revestido, internamente, pelo epitélio da orelha média. Entre esses dois epitélios, persiste uma porção de tecido conjuntivo responsável pela resistência e elasticidade do tímpano. O pavilhão desenvolve-se à custa de proliferações do mesênquima das regiões dorsais do primeiro e segundo arcos branquiais.

Simultaneamente ao desenvolvimento da orelha, diversos outros órgãos estão sendo formados. Os principais eventos que ocorrem entre a $4^{\mathrm{a}}$ e a $8^{\mathrm{a}}$ semanas de gestação estão relacionados na Figura 1. 


\begin{tabular}{|c|c|c|c|c|c|}
\hline \multirow[b]{2}{*}{ SISTEMAS } & \multicolumn{5}{|c|}{ SEMANAS DE GESTAÇÃO } \\
\hline & QUARTA & QUINTA & SEXTA & SÉTIMA & OITAVA \\
\hline Respiratório & $\begin{array}{l}\text { Divertículo } \\
\text { respiratório }\end{array}$ & & $\begin{array}{l}\text { Primórdios do } \\
\text { segmento bronco- } \\
\text { pulmonar }\end{array}$ & & \\
\hline Branquial & $\begin{array}{c}1^{\circ} \text { e } 2^{\circ} \text { arcos } \\
\text { branquiais; } 3^{\circ} \mathrm{e} 4^{\circ} \\
\text { arcos faríngeos }\end{array}$ & & $\begin{array}{l}\text { Saliências } \\
\text { auriculares }\end{array}$ & & $\begin{array}{l}\text { Pavilhão auricular } \\
\text { completo }\end{array}$ \\
\hline Circulatório & $\begin{array}{l}\text { Miocárdio, septum } \\
\text { primum, septo } \\
\text { muscular ventricular }\end{array}$ & $\begin{array}{l}\text { Válvula semi-lunar, } \\
\text { vasos linfáticos e } \\
\text { coronarianos; dutos } \\
\text { endolinfáticos, } \\
\text { válvulas átrio- } \\
\text { ventriculares e } \\
\text { cavidade pericárdica } \\
\text { definitiva }\end{array}$ & $\begin{array}{l}\text { Completa-se o } \\
\text { septum intermedium; } \\
\text { forma-se o sistema } \\
\text { venoso sub-cardinal; } \\
\text { fecha-se o canal } \\
\text { pericárdio peritonial; } \\
\text { fusão do septum } \\
\text { primum e septum } \\
\text { intermedium }\end{array}$ & $\begin{array}{l}\text { Fechamento do canal } \\
\text { pericárdio peritonial; } \\
\text { fusão septum } \\
\text { primum e septum } \\
\text { intermedium }\end{array}$ & $\begin{array}{c}\text { Veia cava superior } \\
\text { definitiva e ramos } \\
\text { maiores do arco } \\
\text { aórtico }\end{array}$ \\
\hline Ocular & $\begin{array}{l}\text { Sulco óptico, } \\
\text { vesícula óptica e } \\
\text { placóide óptico }\end{array}$ & $\begin{array}{l}\text { Invaginação da } \\
\text { vesícula óptica para } \\
\text { o cálice óptico }\end{array}$ & Pigmentos da retina & Início das pálpebras & $\begin{array}{l}\text { Completam-se as } \\
\text { pálpebras }\end{array}$ \\
\hline $\begin{array}{l}\text { Gastro- } \\
\text { intestinal }\end{array}$ & $\begin{array}{c}\text { Placa hepática; } \\
\text { ruptura da } \\
\text { membrana buço- } \\
\text { faríngea; formação } \\
\text { do divertículo } \\
\text { cístico; broto dorsal } \\
\text { pancreático e baço }\end{array}$ & $\begin{array}{l}\text { Pequena e grande } \\
\text { curvatura do } \\
\text { estômago, alça } \\
\text { intestinal primária }\end{array}$ & $\begin{array}{l}\text { Oclusão do lúmen do } \\
\text { tubo gástrico }\end{array}$ & & $\begin{array}{l}\text { Rotação primária da } \\
\text { alça intestinal; } \\
\text { recanalização do } \\
\text { tubo gástrico }\end{array}$ \\
\hline Nervoso & $\begin{array}{l}\text { Fechamento do } \\
\text { neuroporo caudal; } \\
\text { formação dos } \\
\text { núcleos motores dos } \\
\text { nervos cranianos }\end{array}$ & $\begin{array}{l}\text { Nervos espinhais, } \\
\text { vesícula secundária } \\
\text { do cérebro, núcleos } \\
\text { motores da coluna } \\
\text { vertebral, gânglios } \\
\text { sensoriais e } \\
\text { parassimpáticos, } \\
\text { conexão dos } \\
\text { neurônios olfatórios } \\
\text { com o telencéfalo }\end{array}$ & Início do cerebelo & $\begin{array}{l}\text { Expansão do tálamo } \\
\text { e do diencéfalo }\end{array}$ & \\
\hline Apendicular & $\begin{array}{l}\text { Brotos dos membros } \\
\text { superiores e, } \\
\text { posteriormente, dos } \\
\text { inferiores }\end{array}$ & Placa das mãos & $\begin{array}{l}\text { Placa dos pés; raios } \\
\text { dos dedos }\end{array}$ & $\begin{array}{l}\text { Raios de cotovelos e } \\
\text { háluces }\end{array}$ & $\begin{array}{l}\text { Flexão dos ombros, } \\
\text { mãos e pés em } \\
\text { direção à linha } \\
\text { média }\end{array}$ \\
\hline $\begin{array}{l}\text { Gênito- } \\
\text { urinário }\end{array}$ & $\begin{array}{l}\text { Septo uro-retal, } \\
\text { brotos uretéricos }\end{array}$ & $\begin{array}{c}\text { Início do } \\
\text { desenvolvimento dos } \\
\text { metanefros }\end{array}$ & $\begin{array}{l}\text { Início dos cálices } \\
\text { renais maiores, } \\
\text { ascenção renal, } \\
\text { estrias genitais }\end{array}$ & $\begin{array}{l}\text { Cálices renais } \\
\text { menores, ruptura da } \\
\text { membrana } \\
\text { urogenital. }\end{array}$ & $\begin{array}{c}\text { Regressão dos dutos } \\
\text { para-mesonéfricos; } \\
\text { formação dos dutos } \\
\text { deferentes }\end{array}$ \\
\hline Esquelético & $\begin{array}{l}\text { Flexão da parte } \\
\text { cranial do embrião }\end{array}$ & & & $\begin{array}{l}\text { Início da ossificação, } \\
\text { alongamento e } \\
\text { retificação do tronco }\end{array}$ & \\
\hline Tegumentar & & $\begin{array}{l}\text { Melanócitos na } \\
\text { epiderme; formação } \\
\text { da lâmina dentária }\end{array}$ & $\begin{array}{l}\text { Mamilos e folículos } \\
\text { pilosos }\end{array}$ & & $\begin{array}{l}\text { Coroa dos dentes } \\
\text { primitivos }\end{array}$ \\
\hline
\end{tabular}

Larsen (1993), modificado por Lopes (1995)

FIGURA 1: Ocorrência de eventos entre a $4^{\mathrm{a}} \mathrm{e}$ a $8^{\mathrm{a}}$ semanas do período embrionário 


\subsection{Deficiência auditiva sindrômica}

De acordo com Gorlin (1995), os primeiros relatos de deficiência auditiva em quadros sindrômicos foram:

- disostose mandibulofacial (Thomson, 1846-1847)

- retinite pigmentosa e perda auditiva (síndrome de Usher) (Von Graefe, 1858)

- $\quad$ síndrome de Waardenburg (Rizzoli, 1877 e Urbantschitsch, 1910)

- bócio e perda auditiva congênita (Pendred, 1896)

- osteogênese imperfeita e perda auditiva condutiva (Dent, 1900)

A abordagem sistemática para síndromes com perda auditiva foi primeiramente realizada por Hammerschlag nos anos de 1903 a 1905, citado por Gorlin (1995, pág. 3), seguido, posteriormente, por extensos estudos de Fraser e Konigsmark e Gorlin, ambos publicados em 1976. Konigsmark e Gorlin (1976) descreveram mais de 140 síndromes com deficiência auditiva. Levantamento em banco de dados específícos tem mostrado número crescente desses quadros (LDDB, POSSUM). Último levantamento realizado mostrou 680 síndromes associadas à deficiência auditiva, com variadas freqüências, tipos e graus (OMIM - julho 2006).

\subsubsection{Aspectos epidemiológicos e etiológicos}

No tocante à deficiência auditiva sindrômica, a incidência varia de acordo com cada síndrome em questão e o diagnóstico etiológico torna-se difícil de ser estabelecido, em função de sua grande heterogeneidade. Dados de literatura mostram que cerca de 80 diferentes síndromes, que cursam com deficiência auditiva, são decorrentes de alterações cromossômicas e que, cerca de 650 são síndromes gênicas (Gorlin 1995, LDDB 1996, POSSUM 1998, OMIM 2005). Nesse universo incluem-se síndromes em diferentes fases de delineamento e, portanto, o espectro fenotípico, a história natural e o padrão de herança, nem sempre estão bem estabelecidos. A maioria dessas síndromes é decorrente da ação de um único gene e o avanço da biologia molecular tem contribuído no esclarecimento da etiologia e na identificação dos genes responsáveis pelo fenótipo dos diferentes quadros. De acordo com Cryns e van Camp (2004), alguns dos genes identificados que ocasionam as formas sindrômicas de 
deficiência auditiva, são também responsáveis por formas isoladas de deficiência auditiva. Análise de fenótipos, juntamente com a detecção de mutações em algumas famílias afetadas pelas síndromes de Pendred e Usher, mostraram que o gene mutado nessas síndromes pode, também, ocasionar deficiência auditiva não-sindrômica. Levantamento mostra regiões candidatas e/ou genes identificados para diversas síndromes com deficiência auditiva, como o exposto na Tabela 1. 
TABELA 1: Regiões candidatas e/ou genes identificados, responsáveis por diversas síndromes com deficiência auditiva

\begin{tabular}{|c|c|c|}
\hline SÍNDROMES & CROMOSSOMO E REGIÃO & $\begin{array}{c}\text { GENE } \\
(\text { LOCUS) }\end{array}$ \\
\hline Aarskiog-Scott & Xp11.21 & (FGD1) \\
\hline Branquio-oto-renal & $8 \mathrm{q} 13.3$ & EYA1 \\
\hline CHARGE & $8 \mathrm{q} 12.1 ; 7 \mathrm{q} 21.1$ & (CHD7) \\
\hline Coffin-Lowry & $\mathrm{Xp22.2-p22.1}$ & (CLS) \\
\hline Velocardiofacial & $22 \mathrm{q} 11.21-\mathrm{q} 11.23$ & (VCF) \\
\hline EEC tipo I & $7 \mathrm{q} 11.2-\mathrm{q} 21.3$ & (EEC1) \\
\hline EEC tipo II & 19p13.1-q13.1 & (EEC2) \\
\hline EEC tipo III & $3 q 27$ & (EEC3) \\
\hline Espectro oculoauriculovertebral & $14 \mathrm{q} 32$ & - \\
\hline Gernet & $3 q 28-q 29$ & OPA1 \\
\hline Marshall & $1 \mathrm{p} 21$ & COL11A1 \\
\hline Nager & $9 \mathrm{q} 32$ & - \\
\hline Piebaldismo & $4 q 11-q 12 ; 8 q 11$ & KIT / SNAI2 \\
\hline Saethre-Chotzen & $7 \mathrm{p} 21 / 10 \mathrm{q} 26$ & TWIST / FGFR2 \\
\hline Silver-Russell & $11 \mathrm{p} 15.5 / 7 \mathrm{p} 11.2$ & (H19 / IGF2) \\
\hline Stickler tipo I & $12 \mathrm{q} 13.11-\mathrm{q} 13.2$ & COL2A1 \\
\hline Stickler tipo II & $1 \mathrm{p} 21$ & COL11A1 \\
\hline Stickler tipo III & $6 \mathrm{p} 21.3$ & COL11A2 \\
\hline Treacher-Collins & $5 \mathrm{q} 31.3-\mathrm{q} 33.1$ & TCOF1 \\
\hline Usher tipo Ia & $14 q 32$ & (USH1A) \\
\hline Usher tipo $\mathrm{Ib}$ & $11 \mathrm{q} 13.5$ & MYO7A \\
\hline Usher tipo Ic & $11 \mathrm{p} 15.2-\mathrm{p} 14$ & USH1C \\
\hline Usher tipo Id & $10 q 21-q 22$ & $\mathrm{CDH} 23$ \\
\hline Usher tipo Ie & $21 \mathrm{q} 21$ & (USH1E) \\
\hline Usher tipo If & $10 q 21-q 22$ & PCDH15 \\
\hline Usher tipo Ig & $17 \mathrm{q} 24-\mathrm{q} 25$ & USH1G \\
\hline Usher tipo IIa & $1 \mathrm{q} 41$ & USH2A \\
\hline Usher tipo IIb & $3 \mathrm{p} 24.2-\mathrm{p} 23$ & (USH2B) \\
\hline Usher tipo IIc & $5 q 14-q 21$ & (USH2C) \\
\hline Usher tipo III & $3 q 21-q 25$ & USH3A \\
\hline Velocardiofacial & $22 \mathrm{q} 11.2$ & (VCFS) \\
\hline Waardenburg tipo I & $2 q 35-q 37$ & PAX3 \\
\hline Waardenburg tipo IIa & $3 \mathrm{p} 14.1-\mathrm{p} 12.3$ & MITF \\
\hline Waardenburg tipo IIb & $8 \mathrm{q} 11$ & SNAI2 \\
\hline Waardenburg tipo III & $2 q 35-q 37$ & PAX3 \\
\hline Waardenburg tipo IV & $20 \mathrm{q} 13.2-\mathrm{q} 13.3$ & EDN3 \\
\hline
\end{tabular}

Fonte: Friedman et al 2003, OMIM 2006 
Fatores ambientais tais como infecções intrauterinas, agentes químicos e medicamentos, radiação e doenças metabólicas maternas podem agir adversamente no crescimento e desenvolvimento do embrião. A susceptibilidade aos agentes teratógenos depende do genótipo do concepto e, alguns indivíduos respondem mais a certos agentes ambientais do que outros (Cohen Jr 1997). A ação do teratógeno está diretamente relacionada ao período gestacional, sendo especialmente danosa à exposição do embrião entre a segunda e a oitava semanas de gestação. Exceção se faz ao álcool, cujo efeito deletério ocorre durante todo o período gestacional (Gorlin et al 2001). A maioria dos teratógenos leva a um padrão de anomalias que são clinicamente reconhecidas e, dentro desse universo, síndromes que cursam com deficiência auditiva.

Os transtornos congênitos da audição podem ser de origem pré-natal, e uma importante causa são as infecções fetais. Assim como ocorre nas formas de deficiência auditiva não sindrômica, causas infecciosas são, ainda, bastante comuns em países em desenvolvimento. A mais conhecida infecção fetal causadora de deficiência auditiva é a rubéola que, com a introdução dos programas de vacinação, sofreu significativa redução nas duas últimas décadas (Parving 1993). A rubéola congênita pode acometer vários órgãos da criança e a gravidade está relacionada com a época da infecção materna. Quanto mais precoce, maior número de órgãos serão comprometidos, levando a danos graves (deficiência auditiva, anomalias cardíacas, alterações neurológicas e oculares) (Elango 1993). Outra infecção fetal, como a doença de inclusão citomegálica, deve ser investigada como possível etiologia da deficiência auditiva congênita. Alterações como microcefalia, hidrocefalia, calcificações intracranianas, atrofia óptica, distúrbios de linguagem e atraso mental podem estar presentes. Além dessas, existem outras infecções fetais, como toxoplasmose e lues, que podem tanto levar a uma perda auditiva isolada, como resultar em um quadro com múltiplas anomalias. O problema auditivo, nos afetados com a forma congênita da lues, pode não estar presente ao nascimento, instalando-se, geralmente, no início da infầncia, causando dano que varia do grau severo ao profundo (Northern e Downs 1989).

Souza (1995), baseado nos critérios do "Joint Committee on Infant Hearing" (1994), descreveu os fatores de risco que poderiam influenciar na etiologia da deficiência auditiva sindrômica e não sindrômica:

01. história familial de deficiência auditiva infantil;

02. infecções congênitas (rubéola, sífilis, toxoplasmose, citomegalovírus e herpes); 
03. anomalias craniofaciais;

04. peso de nascimento menor do que $1.500 \mathrm{~g}$;

05. hiperbilirrubinemia maior do que $20 \mathrm{mg} / 100 \mathrm{ml}$ de soro;

06. medicação ototóxica por mais de 5 dias (aminoglicosídeos, diuréticos);

07. meningite bacteriana / encefalite viral;

08. sofrimento neonatal (apgar aos 5 minutos de 0 a 3, ausência de respiração espontânea em 10 minutos e hipotonia persistente por 2 horas);

09. ventilação mecânica por mais de 10 dias;

10. septicemia neonatal grave.

Segundo Kountakis et al (2002), o décimo primeiro fator de risco associado à perda auditiva é diabetes materno.

Um dos maiores desafios está nos 20\%-40\% dos casos de deficiência auditiva na infância com etiologia desconhecida. É imprescindível uma minuciosa anamnese da criança, onde os pais forneçam elementos importantes para $o$ esclarecimento de sua etiologia. Esta informação, associada ao exame audiológico pode estabelecer um diagnóstico da deficiência auditiva na criança. A inclusão de procedimentos não-audiológicos, tais como testes sorológicos, raios-X, exames oftalmológicos, avaliação genética, ou seja, uma ampla atuação interdisciplinar é de significativa importância para o diagnóstico etiológico da perda auditiva em uma criança (Parving 1984); pois, pode-se estar frente a um quadro clínico compondo síndromes genéticas específicas e não frente a um caso de deficiência auditiva isolada. Do ponto de vista epidemiológico, para se obter relevantes informações dos fatores que causam a perda de audição, exames sistemáticos devem ser aplicados a um número representativo de crianças portadoras de deficiência auditiva, conseguindo-se, desta forma, dados precisos, não só sobre a prevalência e características dos transtornos da audição, mas também sobre a etiologia dessa deficiência, a qual pode estar associada a um número de variadas síndromes genéticas.

\subsubsection{Delineamento sindrômico}

Muitas anomalias observadas, ao nascimento, podem ser classificadas dentro de uma das três categorias básicas: malformações, deformações e disrupções. 
Existem razões práticas para distingui-las, uma vez que as implicações clínicas são diferentes em cada uma destas categorias (Cohen Jr 1997), como mostra a Tabela 2.

TABELA 2: Comparação geral de malformações, deformações e disrupções

\begin{tabular}{lccc}
\hline \multicolumn{1}{c}{ Características } & Malformações & Deformações & Disrupções \\
\hline Tempo de ocorrência & Embrionária & Fetal & Embrionária / Fetal \\
Nível do distúrbio & Órgão & Região & Área \\
Mortalidade perinatal & + & - & + \\
Variabilidade clínica de uma dada anomalia & Moderado & Leve & Extremo \\
Múltiplas causas de uma dada anomalia & Muito freqüente & Menos comum & Menos comum \\
Correção espontânea & - & + & - \\
Correção postural & - & + & - \\
Correção cirúrgica & + & $-/+$ & + \\
Taxa relativa de recorrência & Mais alta & Mais baixa & Extremamente baixa \\
Freqüência aproximada em recém-nascidos & $2 \%-3 \%$ & $1 \%-2 \%$ & $1 \%-2 \%$ \\
\hline
\end{tabular}

Fonte: Cohen, 1997

Múltiplas anomalias presentes em um único indivíduo podem estar relacionadas etiológica e patogeneticamente, representando uma síndrome, que pode ser conhecida ou não. De acordo com Cohen Jr (1997), se uma síndrome de gênese desconhecida é delineada, seu espectro fenotípico, sua história natural e seu padrão de herança ou risco de recorrência tornam-se conhecidos, permitindo melhores cuidados ao paciente e aconselhamento genético para a família. Se o espectro fenotípico, de determinada condição, é conhecido, anomalias que podem não ser aparentes, porém pertencem ao quadro, devem ser investigadas. Por outro lado, conhecendo-se a história natural de uma doença, propedêutica adequada pode ser estabelecida e, ainda, se o risco de recorrência é conhecido, os pais podem ser adequadamente orientados sobre fututras gestações. Isto é particularmente importante se o risco for alto e se a doença for grave. Esses dados mostram a importância do processo de delineamento sindrômico, que pode ser assim esquematizado (Cohen Jr 1997):

1. Síndromes de etiologia desconhecida

a) Síndromes de padrão único (provisório)

b) Síndromes de padrão de recorrência

2. Síndromes de etiologia conhecida

a) Síndromes de genealogia 
b) Síndromes cromossômicas

c) Síndromes de defeitos bioquímicos

d) Síndromes de causa ambiental determinada

Como síndromes de etiologia desconhecida, entendem-se todas aquelas em que simplesmente não se conhece a causa. Por síndromes de padrão único (provisório), entendem-se aqueles casos tipicamente sindrômicos, nos quais o clínico, após esgotar todos os meios possíveis de diagnóstico, não reconhece uma síndrome clássica. Por síndromes de padrão de recorrência entendem-se aqueles em que dois ou mais indivíduos, não aparentados, apresentam o mesmo conjunto de anomalias, sugerindo (mas não provando) que a patogênese é a mesma, embora neste momento do delineamento, a etiologia ainda seja desconhecida. Síndromes de etiologia conhecida podem ser definidas como aquelas onde ocorrem diversas anomalias etiologicamente relacionadas e baseadas em:

a) ocorrência (ou recorrência) na mesma família, ou o mesmo modelo de herança em diferentes famílias (síndromes de genealogia);

b) presença de uma anomalia cromossômica (síndromes cromossômicas);

c) um defeito específico em uma enzima ou proteína estrutural (síndrome de defeito bioquímico);

d) um fator ambiental reconhecido (síndromes de causa ambiental).

As Síndromes de Genealogia se referem ao conhecimento da causa com base nos dados da genealogia, permanecendo desconhecido o defeito básico, embora sabidamente trate-se de uma síndrome monogênica. Grande parte das síndromes conhecidas pertence a esta categoria. As síndromes cromossômicas são aquelas citogeneticamente bem definidas e compreendem um universo especial dentro da sindromologia. As síndromes de defeitos bioquímicos representam a maioria dos erros inatos do metabolismo, onde defeitos enzimáticos específicos ou de proteínas estruturais são conhecidos. As síndromes de causa ambiental determinada são definidas em termos da ação de um fator ambiental ou teratogênico, atuando sobre o feto e resultando num padrão de anomalias definidas.

O processo de delineamento sindrômico aplica-se igualmente para as síndromes que cursam com deficiência auditiva. Em síndromes, as anomalias não são específicas. Podem ocorrer como defeito isolado ou como componente de várias síndromes. Isto se aplica à deficiência auditiva. Perda auditiva condutiva, sensorioneural 
ou mista podem ocorrer isoladamente ou associadas a outras anomalias, compondo um grande número de diferentes síndromes (Cohen Jr 1991). 


\section{OBJETIVOS}




\section{OBJETIVOS}

Considerando a importância diagnóstica dos quadros com deficiência auditiva associada a múltiplas anomalias, no que se refere ao prognóstico, abordagem terapêutica, prevenção e aconselhamento genético, o presente trabalho teve como objetivos, os seguintes tópicos:

- estabelecer o diagnóstico de uma amostra de indivíduos com deficiência auditiva associada a outras anomalias, cadastrados no CEDALVI/HRAC-USP-Bauru;

- verificar possíveis fatores etiológicos envolvidos;

- investigar possível correlação do tipo de deficiência auditiva com as diferentes síndromes encontradas na amostra;

- estudar e delinear as prováveis síndromes novas que fizerem parte da presente casuística;

- fornecer meios para a realização do aconselhamento genético, através do estabelecimento dos padrões de herança genética, quando possível. 


\section{INDIVÍDUOS ESTUDADOS}




\section{INDIVÍDUOS ESTUDADOS E MÉTODO}

\subsection{Casuística}

O presente trabalho foi realizado de acordo com as normas estabelecidas pelo Comitê de Ética em Pesquisa do Hospital de Reabilitação de Anomalias Craniofaciais-Universidade de São Paulo-Bauru (HRAC-USP-Bauru). Assim, todos os indivíduos examinados participaram, voluntariamente, da pesquisa após esclarecimento a respeito do Termo de Consentimento Livre e Esclarecido (Carta de Informação e assinatura do Termo de Concordância - Anexo 1) (Ofício no 157/2003-UEP-CEP Anexo 2).

A casuística do presente trabalho foi composta por 93 indivíduos, de ambos os sexos, regularmente cadastrados no Centro de Atendimento aos Distúrbios da Audição, Linguagem e Visão (CEDALVI) e no HRAC-USP-Bauru.

Os critérios de inclusão dos indivíduos foram: presença de deficiência auditiva, devidamente documentada por profissionais da área de Fonoaudiologia e Otorrinolaringologia da citada Instituição, e envolvimento de outras estruturas anatômicas e/ou sistemas fisiológicos.

O trabalho teve início no segundo semestre de 2002 e, em um período aproximado de 24 meses, foram avaliados 720 indivíduos com deficiência auditiva, associada, ou não, a outras anomalias. Desses 720 indivíduos, 564 apresentaram deficiência auditiva isolada ou, então, outras anomalias sem a presença de deficiência auditiva. Do restante, 156 indivíduos preencheram os critérios estabelecidos para inclusão na amostra, sendo que 63 foram excluídos por falta aos retornos ambulatoriais e/ou por não apresentarem avaliação de especialidades e/ou de exames subsidiários necessários para auxílio diagnóstico.

\subsection{Metodologia}

Todos os indivíduos foram avaliados, pessoalmente, pelo pesquisador. A metodologia utilizada foi o da aplicação da anamnese genética-clínica e realização de 
exame físico (sob supervisão médica), com a descrição pormenorizada do fenótipo morfológico. Mediante entrevista com os pais ou responsáveis, foram obtidas informações sobre sexo, idade dos pais na época da concepção, tempo gestacional, intercorrências gestacionais (sangramento, uso de substâncias químicas, exposição à radiação, traumas físicos e psíquicos, doenças crônicas e infecciosas), condições perinatais (nascimento, medidas antropométricas, tempo de internação, uso de medicamentos) e levantamento do histórico familial (consangüinidade, recorrência e presença de outras anomalias) de, pelo menos, três gerações. Dados clínicos e de anamnese foram devidamente registrados em protocolo específico (Anexo 3). Documentação fotográfica foi realizada em todos os indivíduos da casuística. Exames subsidiários, tais como, tomografia computadorizada de crânio, tomografia computadorizada de osso temporal, ecografia renal, avaliação oftalmológica, estudo citogenético, entre outros, quando necessários e de possível realização (nesta Instituição ou na cidade de origem do indivíduo), foram solicitados, atendendo à rotina de atendimento de cada paciente. Dados referentes à deficiência auditiva, quanto ao tipo e grau (classificação baseada nos critérios da OMS), foram obtidos através de análise do protocolo das avaliações audiológicas (audiometria tonal, audiometria com reforço visual e audiometria condicionada), constantes no prontuário do paciente. Os casos clínicos, incluindo dados de anamense e resultados de exames subsidiários, foram descritos em forma de tabela.

Para análise dos dados antropométricos, considerou-se a tabela de Tanner e Whitehouse (1976) para peso, comprimento e altura; a tabela de Nellhaus (1976) para perímetro cefálico e a tabela de Feingold e Bossert (1976) para distância intercantal interna e externa. Para a descrição dos tipos de malformações auriculares, utilizou-se a classificação de Meurman (1957):

- microtia tipo I: consiste de uma orelha pequena que mantém a maior parte da estrutura de uma aurícula normal. Na forma mais leve, o canal auditivo externo é, geralmente, evidente e defeitos de cadeia ossicular não são freqüentes;

- microtia tipo II: anomalia, moderadamente severa, que consiste de uma massa longitudinal de cartilagem que se assemelha a uma orelha. A aurícula rudimentar pode ter forma de gancho, de "S" ou de um aparente "question mark";

- microtia tipo III: consiste de uma orelha, geralmente, rudimentar, de tecido mole, sem semelhança com uma orelha normal. 
Para o estabelecimento de etiologia ambiental, de determinado quadro, considerou-se antecedentes gestacionais (uso de substâncias químicas, exposição à teratógenos, doenças crônicas ou infecciosas) e presença de fatores de risco para deficiência auditiva, segundo Souza (1995).

Os critérios utilizados para classificação de prováveis síndromes, associações e seqüências seguiram os estabelecidos pelo Grupo de Trabalho Internacional (GTI) (Spranger et al 1982). Para o estabelecimento diagnóstico dos diferentes quadros utilizou-se, além de literatura pertinente, busca em programas específicos de dismorfologia e sindromologia (LDDB-London Dysmorphology Data Base, POSSUM-Pictures of Standard Syndromes and Undiagnosed Malformations, OMIM-Online Mendelian Inheritance in Man).

Os heredogramas da presente casuística foram elaborados segundo as normas do American Journal of Medical Genetics (2000).

Para análise e discussão, os indivíduos foram, inicialmente, divididos em categorias, segundo a etiologia do quadro. Os indivíduos com síndromes gênicas, pertencentes à categoria I, foram subdivididos em grupos, de acordo com os sistemas envolvidos (Hone e Smith 2001). O acometimento de maior gravidade, de um determinado sistema, foi o critério utilizado nas situações em que o quadro clínico do indivíduo se enquadraria em diferentes grupos. Segue abaixo as diferentes categorias e grupos estabelecidos:

1. Categoria I: síndromes de etiologia genética

- Síndromes cromossômicas

- Síndromes gênicas

- Grupo 1: indivíduos com deficiência auditiva e envolvimento endocrinológico

- Grupo 2: indivíduos com deficiência auditiva e envolvimento músculoesquelético

- Grupo 3: indivíduos com deficiência auditiva e envolvimento neurológico

- Grupo 4: indivíduos com deficiência auditiva e envolvimento ocular

- Grupo 5: indivíduos com deficiência auditiva e envolvimento de orelha externa

- Grupo 6: indivíduos com deficiência auditiva e envolvimento de tegumento 
- Grupo 7: indivíduos com deficiência auditiva e anomalias diversas (miscelânea)

2. Categoria II: síndromes de etiologia ambiental

3. Categoria III: síndromes de etiologia gênica e antecedente de fatores ambientais 
RESULTADOS E DISCUSSÃO 


\section{RESULTADOS E DISCUSSÃO}

Fizeram parte desse estudo, 93 indivíduos com deficiência auditiva e outras estruturas anatômicas e/ou sistemas fisiológicos envolvidos. A razão sexual foi de 51 indivíduos do sexo masculino para 42 do sexo feminino. Nesse universo de pacientes, recorrência familial foi observada em 31 casos e consangüinidade parental em 8. Na amostra, 25 síndromes gênicas conhecidas; 5 síndromes cromossômicas; 5 quadros de etiologia ambiental (3 síndromes conhecidas e 2 quadros não conhecidos) e 2 quadros de etiologia heterogênea, foram estabelecidos em 87 indivíduos. Em 1 caso, não foi possível definir entre 2 condições gênicas e em 5 , não foi possível se chegar a um diagnóstico (Tabela 3). 
TABELA 3: Síndromes gênicas e cromossômicas encontradas na presente casuística

\begin{tabular}{|c|c|c|c|}
\hline \multirow{2}{*}{ SÍNDROMES DIAGNOSTICADAS } & \multicolumn{2}{|c|}{ No DE INDIVÍDUOS } & \multirow{2}{*}{ MODELO DE HERANÇA } \\
\hline & M & $\mathrm{F}$ & \\
\hline \multicolumn{4}{|l|}{ Monogênica } \\
\hline Aarskog-Scott & 01 & - & HL-X recessiva \\
\hline Atresia aural, microtia e perda auditiva condutiva & 05 & - & $\mathrm{HAD} / \mathrm{HAR}$ \\
\hline Branquio-oto-renal & 02 & - & HAD \\
\hline CHARGE & 01 & - & Etiologia heterogênea \\
\hline Coffin-Lowry & 01 & - & HL-X dominante \\
\hline Deleção 22q11.2 & 01 & - & HAD \\
\hline EEC & - & 01 & HAD \\
\hline Espectro oculoauriculovertebral & 10 & 03 & Etiologia heterogênea \\
\hline Espectro oculoauriculovertebral com anomalia radial & 03 & 01 & HAD \\
\hline Filippi & 01 & - & HAR \\
\hline Fine-Lubinsky & - & 02 & Desconhecido \\
\hline Gernet & 01 & 02 & HAD \\
\hline Heimler & 01 & - & HAR \\
\hline Lujan-Fryns & - & 01 & HAD \\
\hline Marshall & - & 01 & HAD \\
\hline Nager & - & 02 & $\mathrm{HAD} / \mathrm{HAR}$ \\
\hline Perrault & - & 02 & HAR \\
\hline Piebaldismo & - & 02 & HAD \\
\hline Pitt-Rogers-Danks & & 01 & HAR \\
\hline Saethre-Chotzen & 01 & - & HAD \\
\hline Silver-Russel & 01 & - & HAD \\
\hline Stickler & 01 & 01 & HAD \\
\hline Treacher-Collins & 01 & 02 & $\mathrm{HAD} / \mathrm{HAR}$ \\
\hline Usher & 01 & 03 & HAR \\
\hline Waardenburg tipo I & 02 & 04 & HAD \\
\hline Waardenburg tipo II & 07 & 08 & HAD \\
\hline Waardenburg tipo III & 01 & - & HAD \\
\hline \multicolumn{4}{|l|}{ Cromossômica } \\
\hline Deleção do cromossomo 8 & - & 01 & - \\
\hline Deleção do cromossomo 18 & 01 & - & - \\
\hline Inversão do cromossomo 6 & 01 & - & - \\
\hline Translocação entre cromossomos 15 e 16 & 01 & - & - \\
\hline Turner & - & 01 & - \\
\hline \multicolumn{4}{|l|}{ Ambiental } \\
\hline Embriopatia diabética & 01 & - & - \\
\hline Fetal alcoólica & 01 & - & - \\
\hline Rubéola congênita & - & 01 & - \\
\hline
\end{tabular}


As Tabelas 4 e 5 mostram, respectivamente, os antecedentes gestacionais ocorridos e os antecedentes relacionados aos fatores de risco para deficiência auditiva (Souza 1995), nos indivíduos da presente casuística.

TABELA 4: Antecedentes gestacionais relevantes da presente casuística

\begin{tabular}{|c|c|c|c|}
\hline ANTECEDENTES GESTACIONAIS & \multicolumn{2}{|r|}{ CASO No } & TOTAL DE INDIVÍDUOS \\
\hline Descolamento de placenta & 02 & $1736 \quad 91$ & 04 \\
\hline Envelhecimento precoce da placenta & & 53 & 01 \\
\hline Oligoidrâmnio & & 31 & 01 \\
\hline Perda líquido amniótico & & 88 & 01 \\
\hline Hipotensão arterial & & 26 & 01 \\
\hline Hipertensão arterial & & $14 \quad 49$ & 02 \\
\hline Pré-eclâmpsia & & 1436 & 02 \\
\hline Infecção do trato urinário/trato respiratório & $18 \quad 30$ & $\begin{array}{llll}42 & 44 & 58 & 82\end{array}$ & 06 \\
\hline Doença exantemática não especificada & & 6189 & 02 \\
\hline Rubéola & & 8390 & 02 \\
\hline Diabetes & & 85 & 01 \\
\hline Intoxicação por agrotóxicos & & 86 & 01 \\
\hline Uso de álcool & & 84 & 01 \\
\hline Uso de antihipertensivos & & 87 & 01 \\
\hline Uso de medicamentos abortivos & & 07 & 01 \\
\hline
\end{tabular}

TABELA 5: Fatores de risco, para deficiência auditiva, observados nos indivíduos da presente casuística

\section{CASO No}

TOTAL DE INDIVÍDUOS

\section{FATORES DE RISCO}

História familial de deficiência auditiva infantil
Anomalias craniofaciais
Infecções congênitas
Peso baixo de nascimento
Ototóxicos
Sofrimento neonatal
Diabetes materno

$02 \quad 01$

$\begin{array}{lllll}61 & 83 & 89 & 90 & 04\end{array}$

$9192 \quad 02$

$\begin{array}{llllll}01 & 87 & 88 & 92 & 93 & 04\end{array}$

Diabetes materno

$\begin{array}{ll}9293 & 02\end{array}$

A Figura 2 mostra o agrupamento dos indivíduos, da presente casuística, conforme o quadro clínico, relacionando as síndromes diagnosticadas, o número de orelhas com limiar auditivo rebaixado, bem como o tipo de deficiência auditiva 
observada. Das 186 orelhas, 171 tiveram limiar auditivo rebaixado. Desse número, deficiência auditiva do tipo condutivo foi observado em $27.48 \%$, do tipo sensorioneural em $66.67 \%$ e do tipo misto, em 5.85\%. Síndromes que cursam com envolvimento de orelha externa e com envolvimento de tegumento foram as mais freqüentes. 


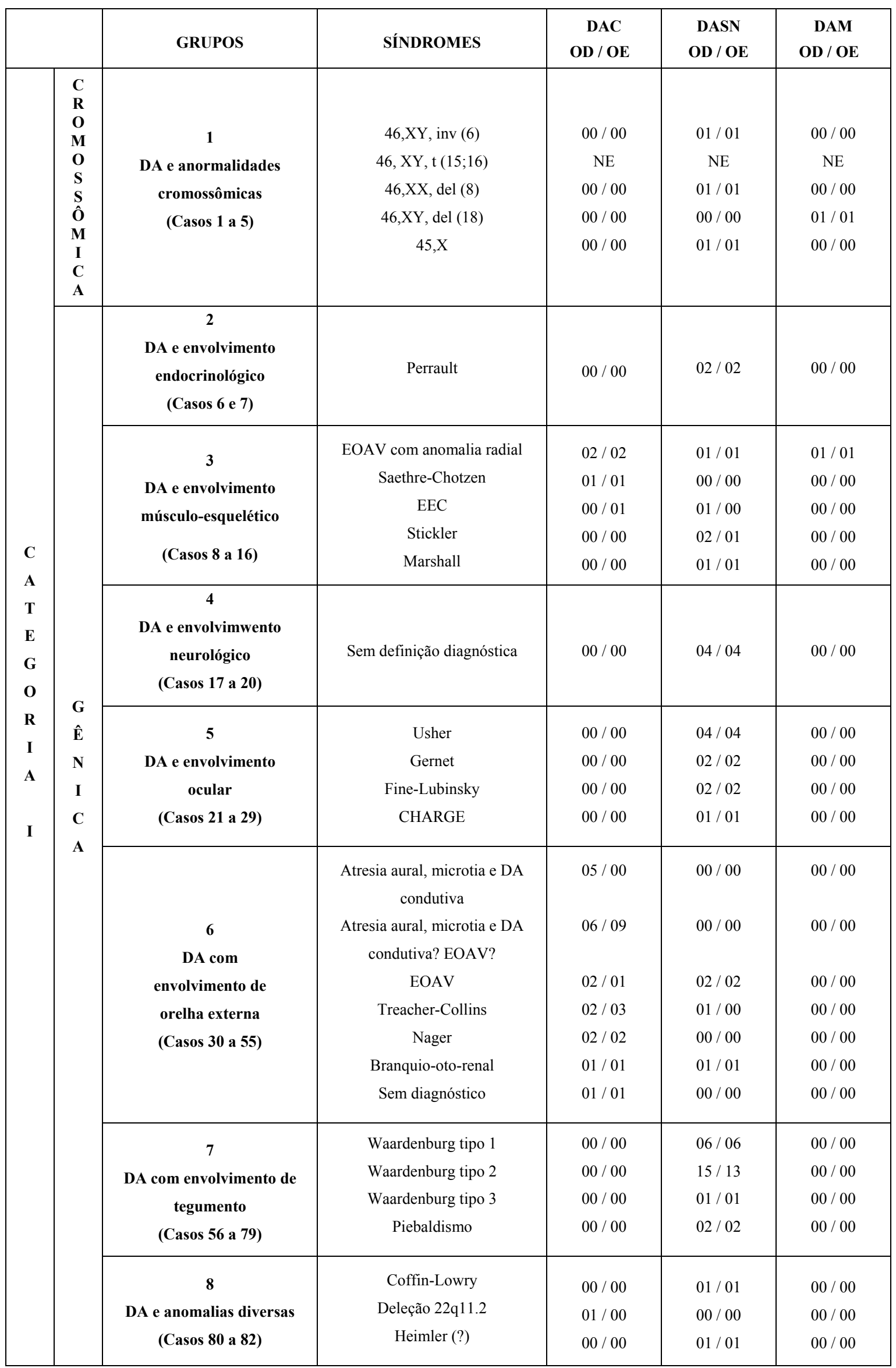


Continuação FIGURA 2

\begin{tabular}{|c|c|c|c|c|c|c|}
\hline & & GRUPOS & SÍNDROMES & $\begin{array}{c}\text { DAC } \\
\text { OD / OE }\end{array}$ & $\begin{array}{r}\text { DASN } \\
\text { OD / OE }\end{array}$ & $\begin{array}{c}\text { DAM } \\
\text { OD / OE }\end{array}$ \\
\hline $\begin{array}{c}\text { C } \\
\mathbf{A} \\
\mathbf{T} \\
\mathbf{E} \\
\mathbf{G} \\
\mathbf{O} \\
\mathbf{R} \\
\mathbf{I} \\
\mathbf{A} \\
\mathrm{II}\end{array}$ & $\begin{array}{l}\mathbf{A} \\
\mathbf{M} \\
\mathbf{B} \\
\mathbf{I} \\
\mathbf{E} \\
\mathbf{N} \\
\mathbf{T} \\
\mathbf{A} \\
\mathbf{L}\end{array}$ & $\begin{array}{l}\text { Síndromes de etiologia } \\
\text { ambiental } \\
\text { (Casos 83 a 87) }\end{array}$ & $\begin{array}{l}\text { Rubéola congênita } \\
\text { Alcoólica fetal } \\
\text { Embriopatia diabética } \\
\text { Múltiplas malformações de } \\
\text { etiologia ambiental }\end{array}$ & $\begin{array}{l}00 / 00 \\
01 / 01 \\
01 / 00 \\
00 / 00\end{array}$ & $\begin{array}{l}01 / 01 \\
00 / 00 \\
00 / 01 \\
01 / 01\end{array}$ & $\begin{array}{l}00 / 00 \\
00 / 00 \\
00 / 00 \\
01 / 01\end{array}$ \\
\hline $\begin{array}{l} \\
\\
\text { C } \\
\text { A } \\
\text { T } \\
\text { E } \\
\text { G } \\
\text { O } \\
\text { R } \\
\text { I } \\
\text { A } \\
\text { III }\end{array}$ & $\begin{array}{l}\mathbf{G} \\
\hat{\mathbf{E}} \\
\mathbf{N} \\
\mathbf{I} \\
\mathbf{C} \\
\mathbf{A} \\
\mathbf{E} \\
\mathbf{F} \\
\mathbf{A} \\
\mathbf{T} \\
\mathbf{O} \\
\mathbf{R} \\
\mathbf{E} \\
\mathbf{S}\end{array}$ & $\begin{array}{c}\text { Síndromes de etiologia } \\
\text { gênica e antecedente de } \\
\text { fatores ambientais } \\
\text { (Casos } 88 \text { a 93) }\end{array}$ & $\begin{array}{c}\text { Pitt-Rogers-Danks } \\
\text { Aarskog-Scott } \\
\text { Filippi } \\
\text { Silver-Russell } \\
\text { Lujan-Fryns } \\
\text { da-Silva? ou } \\
\text { Chudley-McCullough? }\end{array}$ & $\begin{array}{l}00 / 00 \\
00 / 00 \\
00 / 00 \\
00 / 00 \\
00 / 00 \\
00 / 00\end{array}$ & $\begin{array}{l}00 / 00 \\
01 / 01 \\
01 / 01 \\
00 / 00 \\
01 / 01 \\
01 / 01\end{array}$ & $\begin{array}{l}01 / 01 \\
00 / 00 \\
00 / 00 \\
01 / 01 \\
00 / 00 \\
00 / 00\end{array}$ \\
\hline
\end{tabular}

$\mathrm{DAC}=$ deficiência auditiva condutiva; $\mathrm{DASN}=$ deficiência auditiva sensorioneural; $\mathrm{DAM}=$ deficiência auditiva mista; $\mathrm{OD}=\mathrm{orelha}$ direita; $\mathrm{OE}=$ orelha esquerda; $\mathrm{DA}=$ deficiência auditiva; $\mathrm{NE}=$ =não especificado; $\mathrm{EOAV}=$ espectro oculoauriculovertebral

FIGURA 2: Relação das diferentes categorias e grupos com as respectivas síndromes diagnosticadas, o número de orelhas com limiar auditivo rebaixado e o tipo de deficiência auditiva observada 


\subsection{Categoria I: síndromes de etiologia genética}

\subsubsection{Síndromes cromossômicas (Casos 1 a 5)}

$\mathrm{Na}$ Tabela 6 encontram-se dados referentes aos 5 indivíduos com deficiência auditiva e anormalidade cromossômica. As seguintes alterações cromossômicas foram observadas nesse grupo: inversão do cromossomo 6 no Caso 1; translocação entre os cromossomos 15 e 16 no Caso 2; deleção do braço longo do cromossomo 8 no Caso 3; deleção do braço longo do cromossomo 18 (síndrome da deleção $18 \mathrm{q}$ - síndrome de Grouchy) no Caso 4 e, monossomia do cromossomo X (síndrome de Turner) no Caso 5. Perda auditiva sensorioneural foi observada em 3 dos 5 indivíduos desse grupo; perda auditiva mista em 1 e, tipo não especificado em outro. 
TABELA 6: Dados dos indivíduos com deficiência auditiva e anormalidade cromossômica

\begin{tabular}{|c|c|c|c|c|c|c|}
\hline Indivíduo & Sexo & Idade & Sinais clínicos & $\begin{array}{l}\text { Dados gestacionais e perinatais/ } \\
\text { antecedentes pessoais e familiais }\end{array}$ & $\begin{array}{l}\text { Exames complementares e } \\
\text { caracterização da DA }\end{array}$ & Hipótese diagnóstica \\
\hline 01 & M & $4 a 6 m$ & $\begin{array}{l}\text { Baixa estatura; micro-braquicefalia; } \\
\text { hipoplasia malar; sobrancelhas ralas; fendas } \\
\text { palpebrais oblíquas para baixo; glaucoma } \\
\text { congênito bilateral; dentes cônicos; incisivo } \\
\text { central único; orelhas discretamente } \\
\text { posteriorizadas com baixa implantação; } \\
\text { deficiência auditiva; fístula branquial à E; } \\
\text { refluxo gastroesofágico; mamilo extra- } \\
\text { numerário à D; unhas displáscas mãos e pés; } \\
\text { clinodactilia } 5^{\circ} \text { artelho bilateral; } \\
\text { braquidactilia } 2^{\circ} \text { artelho bilateral; pele seca; } \\
\text { prega palmar anômala bilateral; ADNPM } \\
\text { moderado }\end{array}$ & $\begin{array}{l}\text { IMC: } 24 \mathrm{a} / \text { IPC: } 34 \mathrm{a} \quad \mathrm{G} 3 \mathrm{P} 2 \mathrm{~A} 1 \\
\text { Sem intercorrências gestacionais. } \\
\text { Parto cesáreo; gestação a termo. } \\
\mathrm{PN}=2.750 \mathrm{~g}(5<\mathrm{p}<10) \\
\mathrm{EN}=49 \mathrm{~cm}(10<\mathrm{p}<25) \\
\text { Choro demorado. Aos } 12 \text { dias de vida, } \\
\text { apresentou desnutrição } 1^{\circ} \text { grau. Vários } \\
\text { episódios de pneumonia. Provável uso de } \\
\text { ototóxicos. } \\
\text { Aos } 12 \mathrm{a} 2 \mathrm{~m}: \mathrm{A}=120 \mathrm{~cm}(\mathrm{p}<3) \\
\qquad \mathrm{PC}=49.5 \mathrm{~cm}(\mathrm{p}<2) ; \text { corrigido } \\
\text { pela altura: } \mathrm{p}=2\end{array}$ & $\begin{array}{l}\text { Cariótipo: 46,XY, } \\
\text { inv(6)(p22 23q12 13) / aparente } \\
\text { aumento no braço curto do } \\
\text { cromossomo Y } \\
\text { Cariótipo (mãe): } 46, X X \\
\text { Cariótipo (pai): não realizado } \\
\text { Avaliação audiológica:DA } \\
\text { sensorioneural profunda à D e } \\
\text { moderada à } E\end{array}$ & Cromossomopatia \\
\hline 02 & M & $5 \mathrm{a} 10 \mathrm{~m}$ & $\begin{array}{l}\text { Déficit pôndero-estatural; microcefalia; } \\
\text { fronte alta e proeminente; estreitamento } \\
\text { bitemporal; assimetria facial; maloclusão } \\
\text { dentária; micrognatia; orelha D com baixa } \\
\text { implantação e hélix dobrado; atresia CAE à } \\
\text { D; apêndice pré-auricular à D; microtia tipo } \\
\text { III à E com agenesia CAE; deficiência } \\
\text { auditiva; pescoço curto; refluxo } \\
\text { gastroesofágico; disfagia; polegares } \\
\text { palmados; hérnia inguinal bilateral; háluces } \\
\text { sobrepostos; luxação congênita de quadril; } \\
\text { hipotonia generalizada; ADNPM }\end{array}$ & $\begin{array}{l}\text { IMC: } 25 \mathrm{a} / \text { IPC: } 27 \mathrm{a} \quad \text { G1P1A0 } \\
\text { Descolamento de placenta no final da } \\
\text { gestação. } \\
\text { Parto cesáreo; gestação a termo. } \\
\text { PN=2.800g ( } \mathrm{p}=10) \quad \mathrm{EN}=46 \mathrm{~cm}(\mathrm{p}<3) \\
\text { Cianose ao nascimento. Internado } 3 \text { dias. } \\
\text { Aos } 5 \mathrm{a} 10 \mathrm{~m}: \mathrm{P}=12.000 \mathrm{~g}(\mathrm{p}<3) \\
\qquad \begin{array}{l}\mathrm{A}= \\
\mathrm{PC}=47 \mathrm{~cm}(\mathrm{p}<3) \\
\text { pela altura: } \mathrm{p}=2\end{array}\end{array}$ & 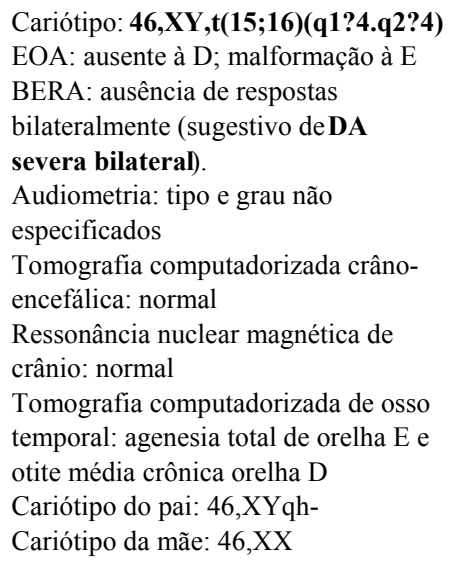 & Cromossomopatia \\
\hline
\end{tabular}


Continuação TABELA 6: Dados dos indivíduos com deficiência auditiva e anormalidade cromossômica

\begin{tabular}{|c|c|c|c|c|c|c|}
\hline Indivíduo & Sexo & Idade & Sinais clínicos & $\begin{array}{l}\text { Dados gestacionais e perinatais/ } \\
\text { antecedentes pessoais e familiais }\end{array}$ & $\begin{array}{l}\text { Exames complementares e } \\
\text { caracterização da DA }\end{array}$ & Hipótese diagnóstica \\
\hline 03 & $\mathrm{~F}$ & $24 \mathrm{a}$ & $\begin{array}{l}\text { Fendas palpebrais oblíquas para cima; filtro } \\
\text { longo; orelhas discretamente rebaixadas; } \\
\text { deficiência auditiva; ADNPM leve }\end{array}$ & $\begin{array}{l}\text { IMC: ? / IPC: ? G3P3A0 } \\
\text { Sem informações gestacionais e perinatais. } \\
\mathrm{PN}=\text { ? EN=? } \\
\text { Mãe e } 1 \text { irmã com atraso mental; } 1 \text { irmã } \\
\text { com DA sensorioneural profunda bilateral. }\end{array}$ & $\begin{array}{l}\text { Cariótipo: } 46, \mathrm{XX}, \text { del(8)(pter- } \\
\text { »q13::q22-»qter) } \\
\text { Avaliação audiológica: DA } \\
\text { neurossensorial profunda bilateral }\end{array}$ & Cromossomopatia \\
\hline 04 & M & 6a $10 \mathrm{~m}$ & $\begin{array}{l}\text { Hipoplasia do arco zigomático; pontes supra- } \\
\text { orbitárias proeminentes; fendas palpebrais } \\
\text { pequenas e oblíquas para cima; nariz } \\
\text { pequeno; filtro curto; lábio superior fino; } \\
\text { lábio inferior evertido; prognatismo; } \\
\text { estenose CAE bilateral; deficiência } \\
\text { auditiva; pescoço curto; clinodactilia } 5^{\circ} \\
\text { dígito bilateral; pé torto congênito bilateral; } \\
\text { hiperextensibilidade articular; ADNPM } \\
\text { moderado }\end{array}$ & $\begin{array}{l}\text { IMC: } 18 \mathrm{a} / \text { IPC: } 18 \mathrm{a} \quad \mathrm{G} 2 \mathrm{P} 2 \mathrm{~A} 0 \\
\text { Sem intercorrências gestacionais. } \\
\text { Parto cesáreo; gestação de } 8 \text { meses. } \\
\mathrm{PN}=2.450 \mathrm{~g}(3<\mathrm{p}<10) \\
\mathrm{EN}=45 \mathrm{~cm}(\mathrm{p}<3) \\
\text { Choro demorado. Nasceu cianótico e com } \\
\text { icterícia. Fototerapia durante } 6 \text { dias. }\end{array}$ & $\begin{array}{l}\text { Cariótipo: 46,XY, del(18)(q21) } \\
\text { Avaliação audiológica: DA mista } \\
\text { severa bilateral }\end{array}$ & $\begin{array}{l}\text { Síndrome da deleção 18q } \\
\text { (Síndrome de Grouchy) }\end{array}$ \\
\hline 05 & $\mathrm{~F}$ & $22 \mathrm{a}$ & $\begin{array}{l}\text { Baixa estatura; obesidade; epicanto bilateral; } \\
\text { orelhas grandes; anti-tragus proeminentes; } \\
\text { lóbulos grandes; deficiência auditiva; } \\
\text { pescoço curto; edema mãos e pés; } \\
\text { braquidactilia } 4^{\circ} \text { artelho bilateral; } \\
\text { hipodesenvolvimento dos caracteres sexuais } \\
\text { secundários; hipotireoidismo; ADNPM } \\
\text { moderado }\end{array}$ & $\begin{array}{l}\text { IMC: } 20 \mathrm{a} / \text { IPC: } 18 \mathrm{a} \quad \text { G3P3A0 } \\
\text { Sem intercorrências gestacionais. } \\
\text { Parto normal; gestção a termo. } \\
\mathrm{PN}=2.700 \mathrm{~g}(3<\mathrm{p}<10) \\
\text { EN }=\text { ? } \\
\text { Cianose ao nascimento, necessitando de } \\
\text { O2 por algumas horas. } \\
\text { Aos 22a idade: } \mathrm{A}=147 \mathrm{~cm}(\mathrm{p}<3)\end{array}$ & $\begin{array}{l}\text { Cariótipo: } \mathbf{4 5 , X} \\
\text { Eletroencefalograma: foco em T6 } \\
\text { Avaliação audiológica: DA } \\
\text { neurossensoral moderada bilateral }\end{array}$ & $\begin{array}{l}\text { Monossomia do X } \\
\text { (Síndrome de Turner) }\end{array}$ \\
\hline
\end{tabular}



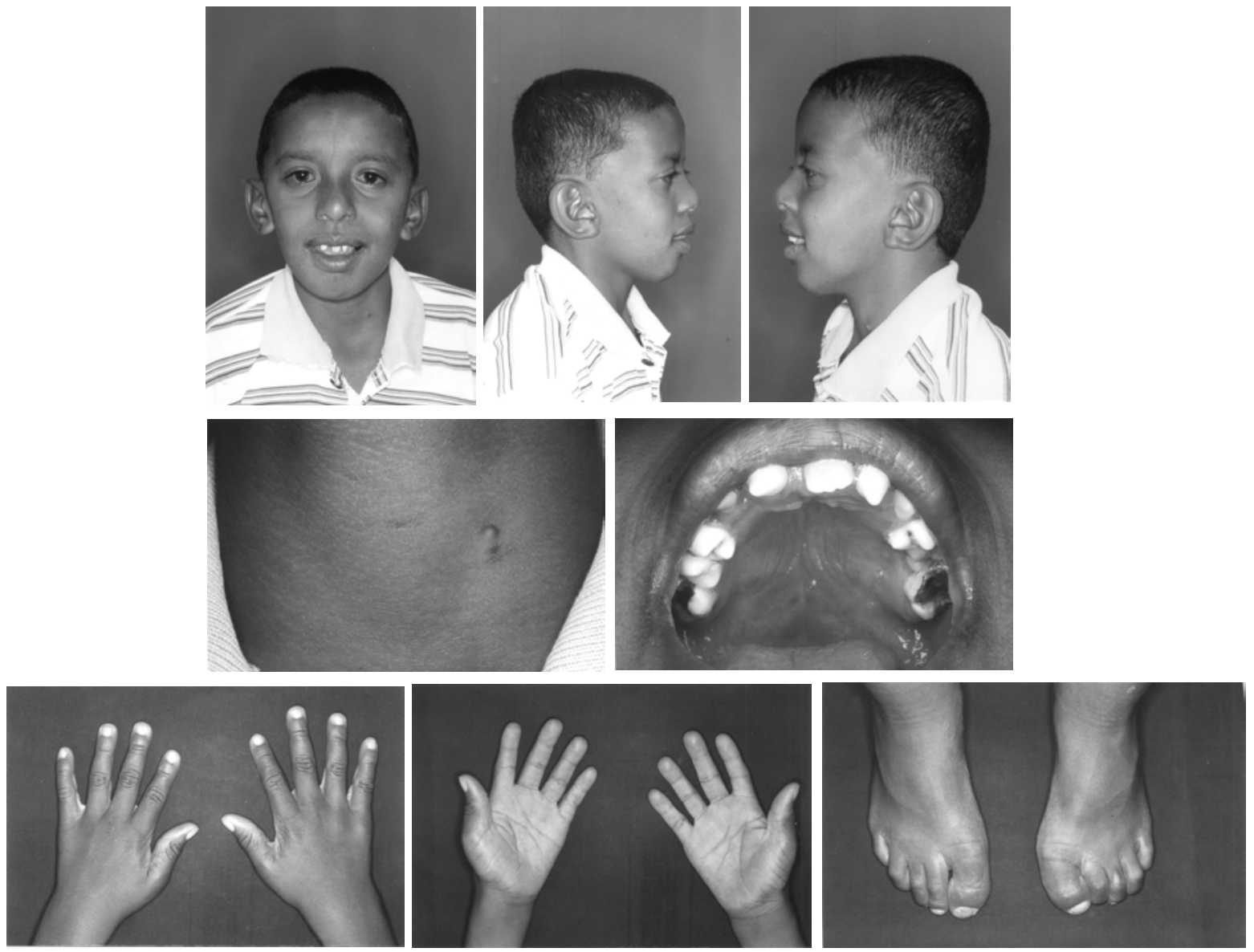

FIGURA 3: Aspectos clínicos do Caso 01

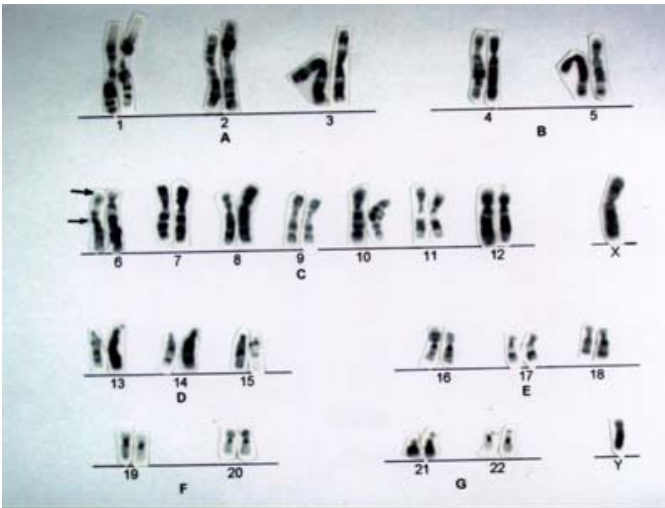

FIGURA 4: Caso 01 - Cariótipo 46,XY,inv(6)(p22 23q12 13) 

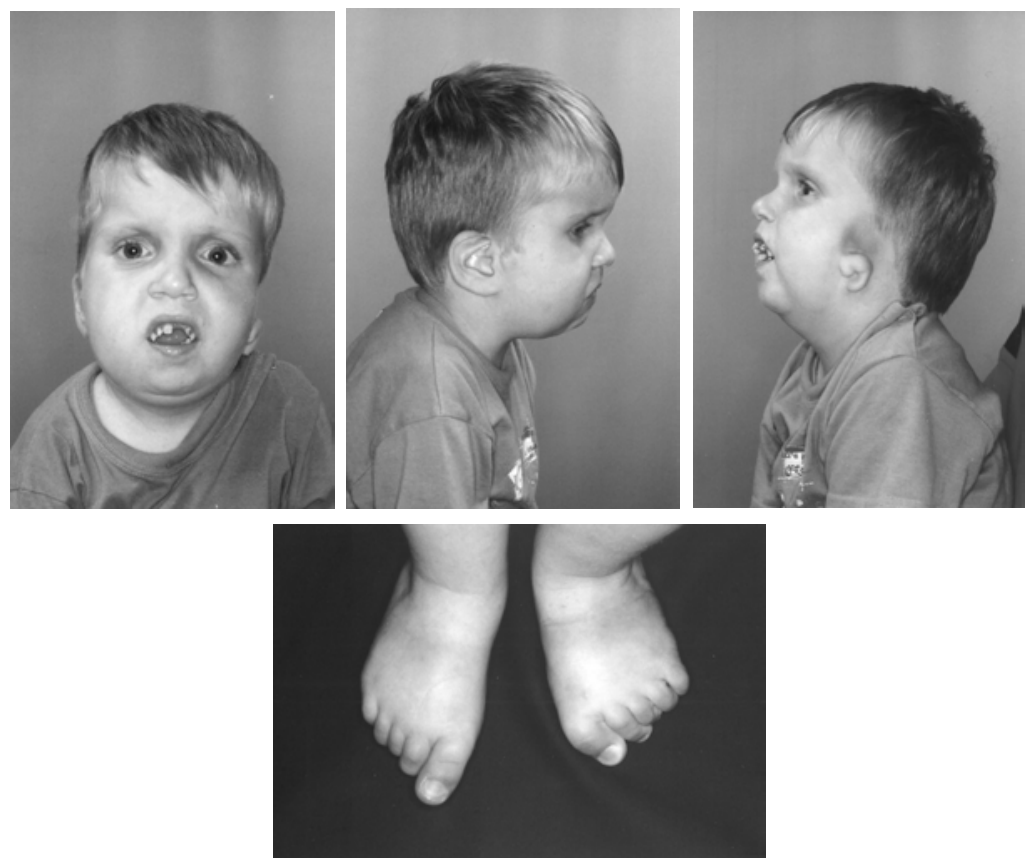

FIGURA 5: Aspectos clínicos do Caso 02
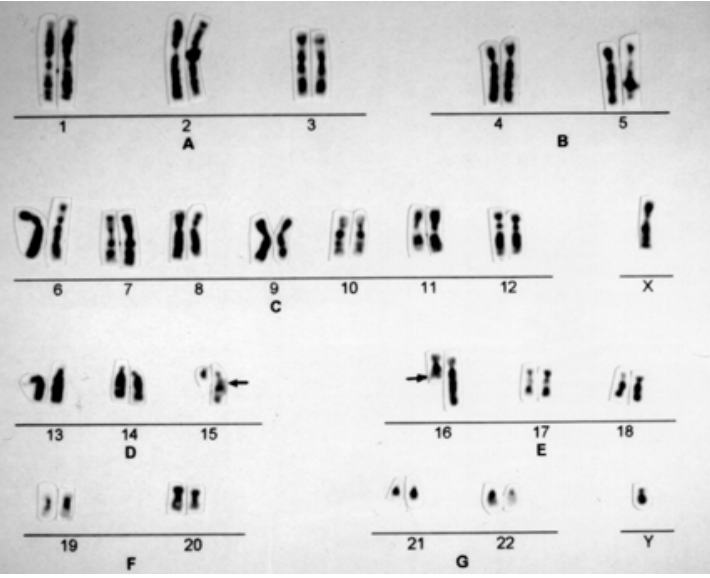

FIGURA 6: Caso 02 - Cariótipo 46,XY,t(15;16)(q1?4.q2?4) 

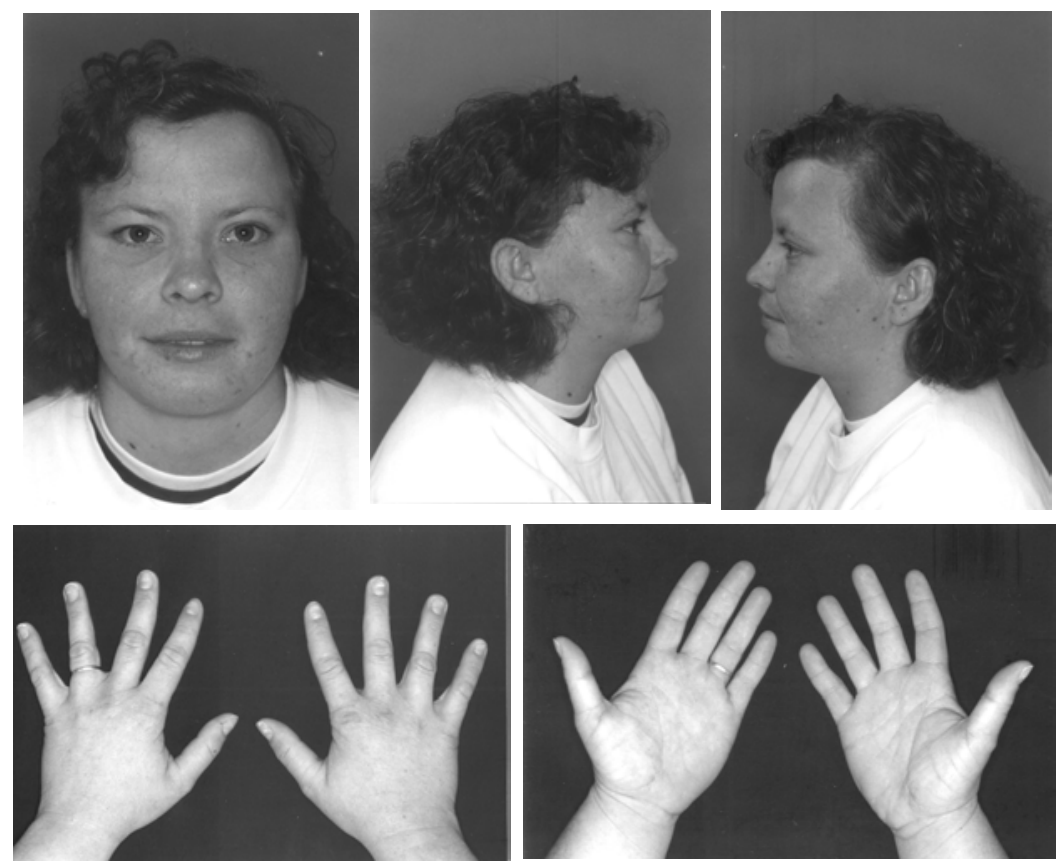

FIGURA 7: Aspectos clínicos do Caso 03

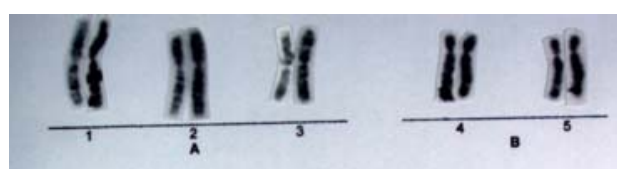

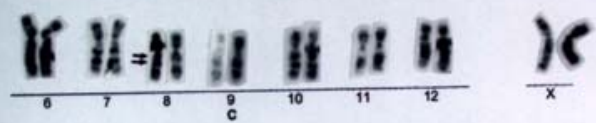

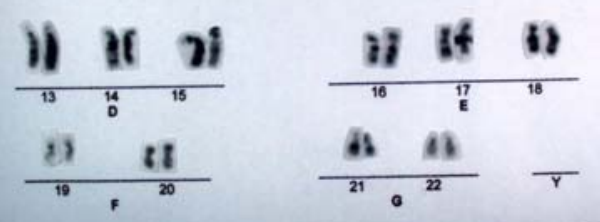

FIGURA 8: Caso 03 - Cariótipo 46,XX, del(8)(pter $\rightarrow$ q13::q22 $\rightarrow$ qter)

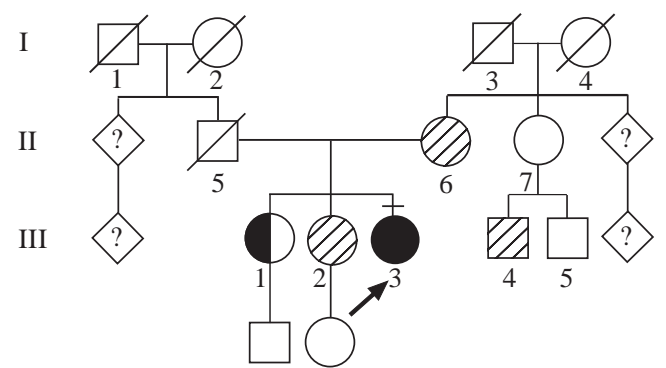

- Propósita

D DA sensorioneural profunda Atraso mental

FIGURA 9: Heredograma da família do Caso 03 

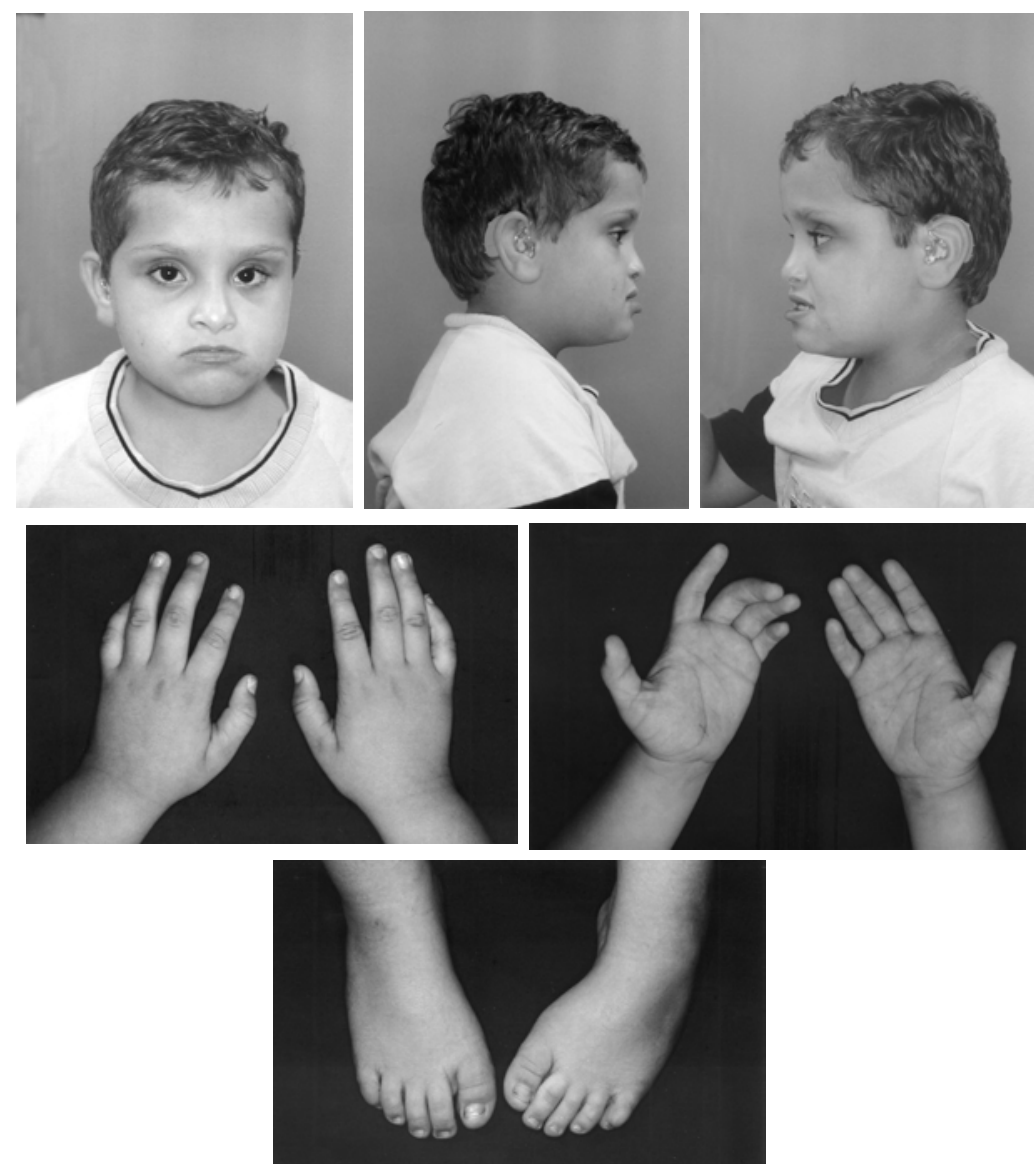

FIGURA 10: A: Aspectos clínicos do Caso 04

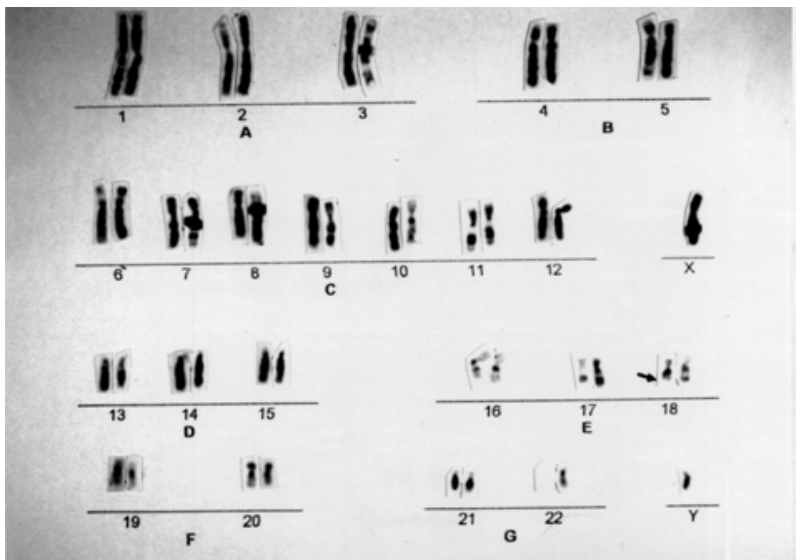

FIGURA 11: Caso 04 - Cariótipo 46,XY,del(18)(q21) 

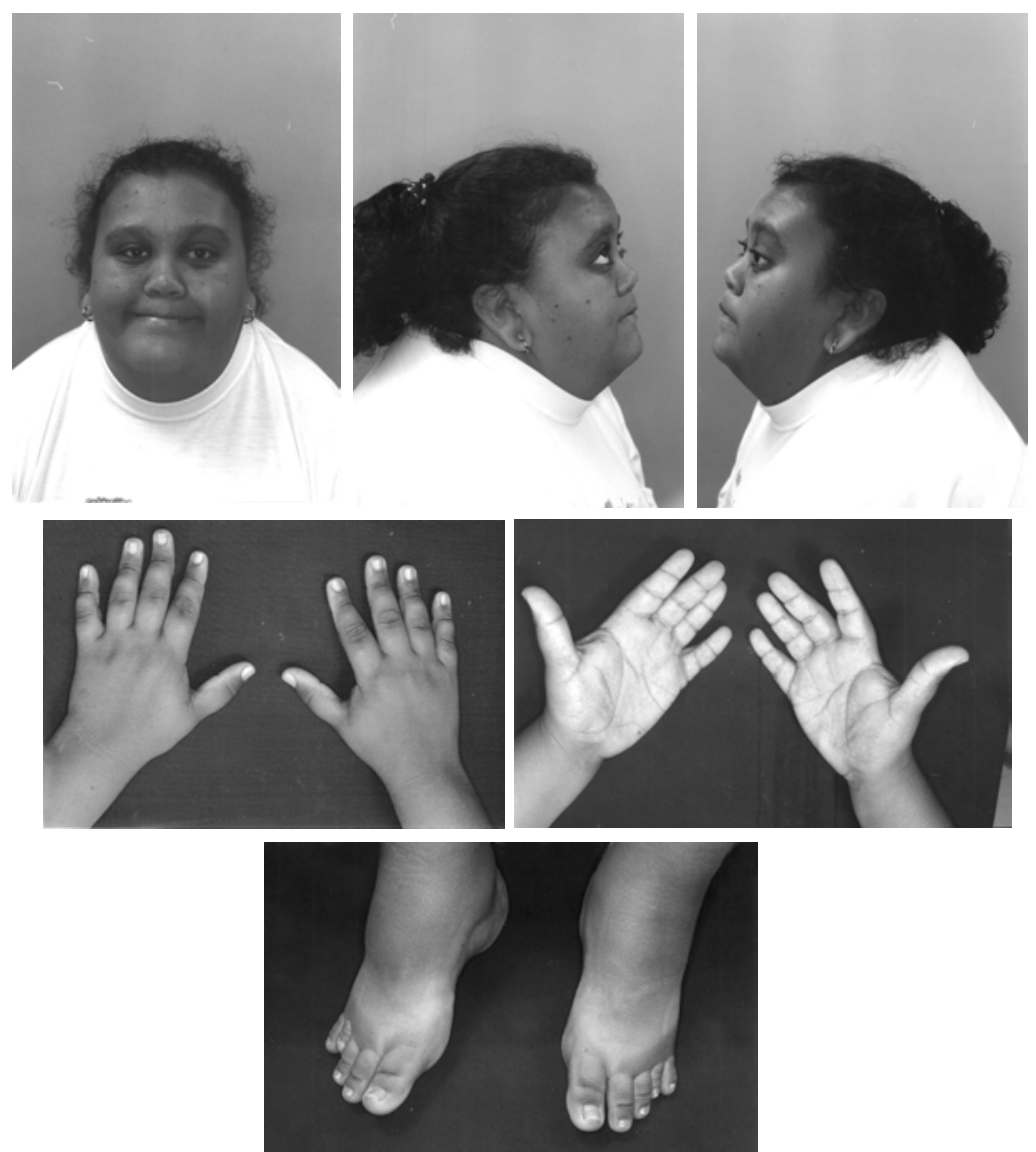

FIGURA 12: Aspectos clínicos do Caso 05

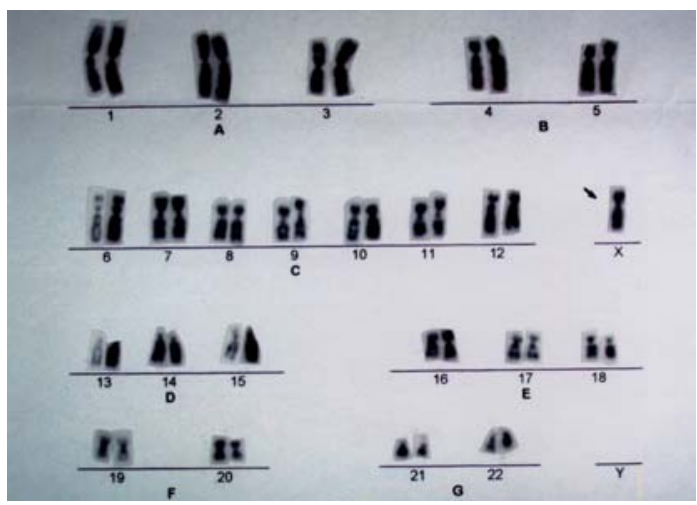

FIGURA 13: Caso 05 - Cariótipo 45,X 
Os distúrbios cromossômicos formam uma importante categoria de doenças genéticas. Nesses, o defeito não se deve a um único erro no código genético, mas a um excesso ou a uma deficiência dos genes contidos em cromossomo inteiro ou segmentos cromossômicos. Os distúrbios cromossômicos são bem comuns, afetando cerca de 7 em cada 1.000 nativivos, e contribuem para uma grande proporção de todas as perdas reprodutivas, malformações e atraso mental. Os distúrbios citogenéticos estão presentes em quase $1 \%$ dos nativivos, em cerca de $2 \%$ das gestações de mulheres com mais de 35 anos que fizeram diagnóstico pré-natal e, em 50\% dos abortos espontâneos de primeiro trimestre (Nussbaum et al 2002). Estas alterações podem ser numéricas ou estruturais e podem envolver um ou mais autossomos, cromossomos sexuais ou ambos, simultaneamente. As anomalias cromossômicas específicas são responsáveis por mais de 100 síndromes identificáveis e, em muitas delas a associação com deficiência auditiva é bem documentada. Na presente casuística, quatro indivíduos (Casos 1, 2, 3 e 4 - Tabela 6) apresentaram alterações cromossômicas autossômicas estruturais (inversão pericêntrica do 6; translocação 15/16; deleção intersticial do 8q e deleção do 18q) e um indivíduo (Caso 5 - Tabela 6) apresentou alteração numérica do cromossomo X (monossomia do X). De acordo com Nussbaum et al (2002), rearranjos estruturais estão presentes em cerca de 1 em 375 neonatos. Essa troca cromossômica ocorre espontaneamente em uma freqüência baixa ou pode ser induzida por agentes clastogênicos, tais como radiação ionizante, algumas infecções virais e muitas substâncias químicas. Nos rearranjos não-balanceados (deleções, duplicações, cromossomos marcadores e em anel, isocromossomos, cromossomos dicêntricos) o fenótipo do indivíduo é anormal. Já nos balanceados (inversões, translocações), em geral, não há efeito fenotípico. Em algumas situações, embora os rearranjos estejam, aparentemente, balanceados citogeneticamente, pode ocorrer desbalanceamento ao nível molecular com conseqüente implicação fenotípica. Alterações fenotípicas ou atraso mental, têm sido, embora raramente, relatados em indivíduos com rearranjos balanceados (Wenstrom et al 1991, Pettenati et al 1995, Nussbaum et al 2002).

O Caso 1 (Tabela 6; Figura 3), da presente casuística, apresentou alteração fenotípica e, ao exame citogenético, através de bandeamento $\mathrm{G}$, foi detectado inversão no cromossomo número 6, com pontos de quebra entre as bandas p22 e p23 e as bandas q12 e q13 [46,XY,inv(6)(p22 23q12 13)] (Figura 4). Inversões pericêntricas do cromossomo 6, em indivíduos fenotipicamente anormais, têm sido descritas (Duckett 
e Roberts 1980, Kaiser 1984, Wenstrom et al 1991, Markie et al 1996, Anton et al 2002, Sood et al 2004, Kerketta et al 2005). Achados como: alterações oculares, deficiência auditiva, anomalia dentária e atraso mental, observados no Caso 1, foram descritos em três irmãos, entre cinco afetados (três gerações) de uma família relatada por Wenstrom et al (1991). Todos os afetados apresentaram inversão no cromossomo 6 [46,XX ou XY,inv(6)(p23q23.1)]. Tanto o Caso 1, quanto os descritos por Wenstrom et al (1991), ampliam o conhecimento das anormalidades fenotípicas relacionadas a alterações do cromossomo 6. Microcefalia, incisivo central único e fístula branquial, presentes no Caso 1, embora relacionados a vários outros quadros, podem pertencer ao quadro em questão. Cabe salientar, ainda, que intercorrências neonatais (desnutrição, pneumonias de repetição) relacionadas ao uso de medicamentos, podem ter tido influência na etiologia e/ou gravidade da perda auditiva do caso em questão. Em relação à alteração cromossômica estrutural do Caso 1, algumas considerações foram feitas: que tenha ocorrido de novo e, que tenha, ou não, relação com o fenótipo; que tenha sido herdada e que o fenótipo não teria relação com o achado citogenético. Embora fenotipicamente normais, somente a genitora foi avaliada citogeneticamente (cariótipo normal), o que impossibilita uma conclusão.

O Caso 2 (Tabela 6; Figura 5), da presente casuística, apresentou múltiplas anomalias e, ao exame citogenético (bandeamento G), detectou-se translocação recíproca entre os cromossomos 15 e 16 [(46,XY,t(15;16)(q1?4.q2?4)] (Figura 6). As translocações recíprocas são relativamente comuns e são encontradas em cerca de 1 em 600 neonatos. Tais translocações, em geral, não são prejudiciais, embora sejam mais comuns em indivíduos com atraso mental, do que na população em geral (Nussbaum et al 2002). Embora literatura pertinente seja escassa, Bahuau et al (2000) descreveram uma família apresentando neurofibromatose e translocação recíproca entre os cromossomos 15 e 16 e concluíram que não havia relação patogenética entre o quadro clínico e o rearranjo estrutural. As alterações craniofaciais, presentes no Caso 2, sobrepõem-se àquelas observadas nos indivíduos com microssomia hemifacial (OMIM 164210). Apesar de relatos de indivíduos com microssomia hemifacial e alterações cromossômicas, translocação recíproca não está associada ao complexo fenotípico da microssomia hemifacial (Hathout et al 1998, de Ravel et al 2001, Dabir e Morrison 2006). Além do fenótipo facial sobreposto ao quadro de microssomia hemifacial, o Caso 2 apresentou atraso mental, achado incomum nessa condição. É possível que, o 
caso em questão, apresente microssomia hemifacial e que, a presença da translocação tenha agravado o quadro, visto que esse tipo de rearranjo cromossômico foi observado, com maior freqüência, em indivíduos com atraso mental. Considerando a possibilidade de tratar-se de microssomia hemifacial, a deficiência auditiva estaria compatível com esse quadro. Finalmente, nesse caso a translocação ocorreu de novo, uma vez que os genitores eram citogeneticamente normais.

Deleções autossômicas, citogeneticamente visíveis, têm uma incidência de 1 em 7.000 nativivos (Nussbaum et al 2002). Segundo esses mesmos autores, várias deleções foram identificadas em indivíduos dismórficos, porém, o conhecimento relacionado aos genes funcionais nos segmentos deletados e, sua relação com as conseqüências fenotípicas, ainda é limitada. O Caso 3 (Tabela 6; Figuras 7 e 9; III-3) apresentou sinais faciais menores (fendas palpebrais oblíquas para cima, filtro longo, discreto rebaixamento das orelhas) associados à deficiência auditiva sensorioneural grave e leve atraso mental. Deleção intersticial no braço longo do cromossomo 8 [46,XX, del(8)(pter $\rightarrow$ q13::q22 $\rightarrow$ qter)] (Figura 8) foi detectado nesse caso. Essa mesma deleção foi, previamente, observada em uma menina com fissura labiopalatina e múltiplas anomalias menores (Orye e Craen 1983). Os autores comentaram que a propósita não apresentava achados ósseos da síndrome de Langer-Giedion (OMIM 150230). Esse quadro está associado com deleção do braço longo do cromossomo 8 (8q24.11-q24.13) e, clinicamente, é caracterizado por aparência facial peculiar, deficiência auditiva, múltiplas exostoses e atraso mental. $\mathrm{O}$ achado citogenético do Caso 3 e, ainda, o fenótipo leve, sem comprometimento ósseo, estão mais relacionados ao caso descrito por Orye e Craen (1983) do que aos indivíduos com a síndrome LangerGiedion. Deficiência auditiva sensorioneural, presente no caso em questão, não foi observado por Orye e Craen (1983). Este achado, também presente em uma irmã (Figura 9; III-1) do Caso 3, pode não estar relacionado ao quadro, ou então, representar uma expansão fenotípica do mesmo. É possível, ainda, que a genitora (Figura 9; II-6) e outra irmã (Figura 9, III-2), ambas com atraso mental, sejam afetadas. A impossibilidade de avaliar a família citogeneticamente, não permite conclusões.

O Caso 4 (Tabela 6; Figura 10), da presente casuística, apresentou múltiplas anomalias e, ao exame citogenético, detectou-se deleção no braço longo do cromossomo 18 [46,XY,del(18)(q21)] (Figura 11) compatível com síndrome da deleção do cromossomo 18q (síndrome de Grouchy - OMIM 601808). Essa é uma das 
síndromes de deleção mais freqüentes e, ocorre em, aproximadamente, 1 em cada 40.000 nativivos (Chen et al 2003). O fenótipo é altamente variável, mas caracteriza-se, principalmente, por baixa estatura, dismorfismo facial, deficiência auditiva, deformidade dos pés, hipotonia e atraso mental. Outras manifestações observadas foram: fissura labiopalatina; atresia do canal auditivo externo e alterações oftalmológicas, vertebrais, cardíacas, geniturinárias, endocrinológicas e neurológicas (Chen et al 2003, Versacci et al 2005, Schaub et al 2005). A gravidade fenotípica está correlacionada, não somente com o tamanho da deleção, mas também com a localização da deleção no cromossomo (Schaub et al 2005). O Caso 4, da presente casuística, apresentou fenótipo facial e manifestações clínicas similares àquelas descritas nos indivíduos com síndrome da deleção do 18q. Perda auditiva mista bilateral foi observada no caso em questão. Atresia do canal auditivo externo, presente neste caso, é responsável pelo componente condutivo da perda auditiva. Trabalhos têm mostrado que deficiência auditiva, sensorioneural ou condutiva, está presente em $50 \%$ a $80 \%$ dos indivíduos com a síndrome da deleção do 18q (Jayarajan et al 2000). Atresia aural foi observada em $61 \%$ dos indivíduos, com essa síndrome, avaliados por Nuijten et al (2003). A deleção do cromossomo 18q está associada a fenótipo alterado e, embora os genitores não apresentem avaliação citogenética, são fenotipicamente normais. Esse fato pressupõe que a alteração citogenética ocorreu de novo no indivíduo em questão.

As anomalias dos cromossomos sexuais, como as anomalias dos autossomos, podem ser numéricas ou estruturais. A aneuploidia dos cromossomos $\mathrm{X}$ e Y são relativamente comuns e, as anomalias dos cromossomos sexuais estão entre as mais comuns de todos os distúrbios genéticos humanos, com uma incidência geral de cerca de 1 em 400 a 500 nascimentos. Os fenótipos associados a estas alterações cromossômicas, em geral, são menos graves do que aqueles associados aos distúrbios autossômicos comparáveis, devido à inativação do X. As alterações numéricas mais comuns de cromossomo sexual em nativivos e em fetos são as trissomias (XXY, XXX, XYY), mas todos os três são raros em abortos espontâneos. Em contraste, a monossomia do $\mathrm{X}$ é menos freqüente em nativivos, mas é a anomalia cromossômica mais comum relatada em abortos espontâneos (Nussbaum et al 2002). O Caso 5 (Tabela 6; Figura 12), da presente casuística, apresentou manifestações clínicas compatíveis com a monossomia do X (síndrome de Turner) (Figura 13). Citogeneticamente, a síndrome de Turner é caracterizada pela ausência, completa ou parcial, de um 
cromossomo X. Essa anomalia está presente em 1\% a 2\% de todos os conceptos e, mais de $99 \%$ desses fetos são abortados espontaneamente. A clássica monossomia 45,X é a mais comum (cerca de 50\% dos casos), porém, anormalidades estruturais do cromossomo $\mathrm{X}$ ou formas de mosaicismo, podem ocorrer (Beckman et al 2004). O espectro clínico da síndrome de Turner é amplo, com fenótipo que varia de leve (baixa estatura ou amenorréia secundária) a grave (baixa estatura, disgenesia gonadal, linfedema e típica aparência dismórfica), implicando, por vezes, em diagnóstico tardio (Elsheikh et al 2002, Ostberg e Conway 2003). Audiologicamente, existe uma forte relação da síndrome de Turner com patologia recorrente de orelha média na infância, bem como deficiência auditiva sensorioneural progressiva com variáveis idades de início (Beckman et al 2004). O Caso 5, da presente casuística, apresentou baixa estatura, pescoço curto, edema de mãos e pés e hipodesenvolvimento dos caracteres sexuais secundários, sinais estes cardinais da síndrome de Turner. Citogeneticamente foi detectado monossomia clássica do X $(45, \mathrm{X})$. Antecedente de hipotireoidismo e de atraso no desenvolvimento neuromotor foi referido no presente caso. Embora atraso mental seja observado nas mulheres portadoras de mosaico 45,X/46,X,r(X), não é usual naquelas com monossomia do X (Kubota et al 2002). É possível que, para o presente caso, o comprometimento no desenvolvimento global tenha relação com o hipotireoidismo não tratado precocemente. Deficiência auditiva sensorioneural bilateral, observado no Caso 5, é comum nas mulheres com síndrome de Turner, particularmente naquelas com cariótipo 45,X e 45,X/46,X,i(Xq). Embora a etiologia da perda auditiva condutiva esteja bem estabelecida na síndrome de Turner e, relacionada à alta prevalência de otite média nesta população, o mesmo não ocorre com a perda auditiva sensorioneural (Roush et al 2000). 


\subsubsection{Síndromes gênicas (Casos 6 a 83)}

\subsubsection{Grupo 1: Indivíduos com deficiência auditiva e envolvimento endocrinológico (Casos 6 e 7)}

Os dados referentes aos 2 indivíduos (Casos 6 e 7) pertencentes a esse grupo, encontram-se na Tabela 7. A possibilidade diagnóstica considerada para ambos, foi síndrome de Perrault. Deficiência auditiva sensorioneural foi observada nos 2 casos. 
TABELA 7: Dados dos indivíduos com deficiência auditiva e envolvimento endocrinológico

\begin{tabular}{|c|c|c|c|c|c|c|}
\hline Indivíduo & Sexo & Idade & Sinais clínicos & $\begin{array}{l}\text { Dados gestacionais e perinatais/ } \\
\text { antecedentes pessoais e familiais }\end{array}$ & $\begin{array}{l}\text { Exames complementares e } \\
\text { caracterização da DA }\end{array}$ & $\begin{array}{l}\text { Hipótese diagnóstica } \\
\text { (modelo de herança) }\end{array}$ \\
\hline 06 & $\mathrm{~F}$ & $25 \mathrm{a} 1 \mathrm{~m}$ & $\begin{array}{l}\text { Orelhas proeminentes; deficiência auditiva; } \\
\text { hipodesenvolvimento dos caracteres } \\
\text { sexuais secundários; amenorréia primária }\end{array}$ & $\begin{array}{l}\text { IMC: } 23 \mathrm{a} / \mathrm{IPC}: 31 \mathrm{a} \quad \mathrm{G} 2 \mathrm{P} 2 \mathrm{~A} 0 \\
\text { Sem intercorrências gestacionais e } \\
\text { perinatais. } \\
\text { Parto normal; gestação a termo. } \\
\mathrm{PN}=3.000 \mathrm{~g}(\mathrm{P}=25) \\
\mathrm{EN}=48 \mathrm{~cm}(10<\mathrm{p}<25) \\
1 \text { irmão com } \mathrm{DA} \text { sensorioneural profunda } \\
\text { bilateral. }\end{array}$ & $\begin{array}{l}\text { Cariótipo: 46,XX } \\
\text { Ultrassonografia pélvica: hipoplasia de } \\
\text { útero; ovário E hipoplásico e D não } \\
\text { visualizado } \\
\text { Avaliação endocrinológica: } \\
\text { hipogonadismo hipergonadotrófico } \\
\text { Avaliação audiológica: DA } \\
\text { sensorioneural severa bilateral }\end{array}$ & $\begin{array}{c}\text { Síndrome de Perrault } \\
\text { (HAR) }\end{array}$ \\
\hline 07 & $\mathrm{~F}$ & $14 \mathrm{a} 10 \mathrm{~m}$ & 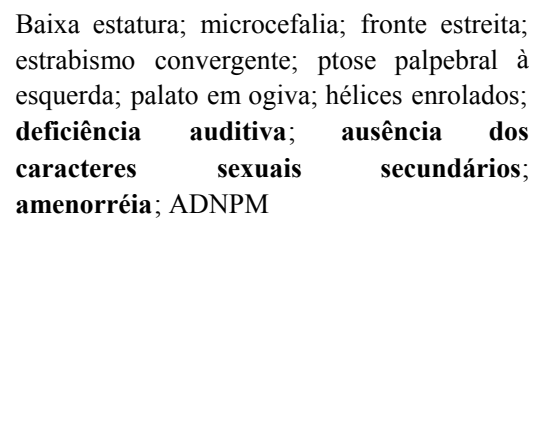 & $\begin{array}{l}\text { IMC: 21a / IPC: ? G4P4A0 } \\
\text { Uso de medicamentos abortivos no } 10 . \\
\text { mês gestacional (não soube referir nome). } \\
\text { Parto normal; gestação a termo. } \\
\mathrm{PN}=3.140 \mathrm{~g}(\mathrm{P}=50) \\
\mathrm{EN}=49 \mathrm{~cm}(\mathrm{P}=25) \\
\text { Meia-irmã com displasia } \\
\text { craniofrontonasal. } \\
\text { Aos } 17 \mathrm{a} 4 \mathrm{~m}: \mathrm{P}=40.000 \mathrm{~g}(\mathrm{p}<3) \\
\qquad \mathrm{A}=147.5 \mathrm{~cm}(\mathrm{p}<3) \\
\mathrm{PC}=52 \mathrm{~cm}(\mathrm{p}=2) ; \text { corrigido } \\
\quad \text { pela altura: } 2<\mathrm{p}<50\end{array}$ & $\begin{array}{l}\text { Cariótipo: } 46, \mathrm{XX} \\
\text { Ultrassonografia pélvica: útero com } \\
\text { constituição normal; ovários não } \\
\text { visualizados } \\
\text { Avaliação audiológica: DA } \\
\text { sensorioneural profunda bilateral }\end{array}$ & $\begin{array}{c}\text { Síndrome de Perrault } \\
\text { (HAR) }\end{array}$ \\
\hline
\end{tabular}




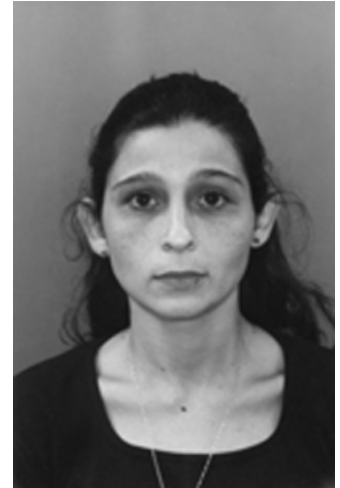

FIGURA 14: Aspectos clínicos do Caso 06

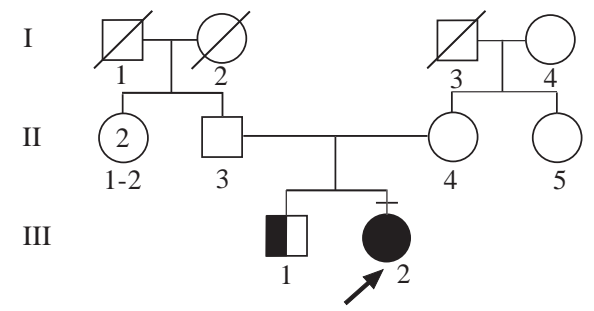

- Propósita

DA sensorioneural profunda

FIGURA 15: Heredograma da família do Caso 06

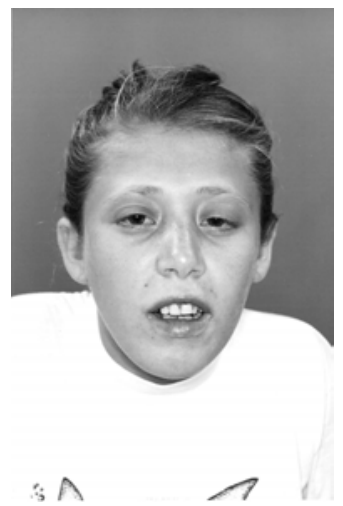

FIGURA 16: Aspectos clínicos do Caso 07 
Várias condições genéticas, envolvendo alteração endocrinológica e deficiência auditiva, são conhecidas, sendo a síndrome de Perrault (OMIM 233400), a mais freqüentemente observada. Trata-se de uma condição determinada por gene autossômico recessivo, que cursa com disgenesia ovariana e deficiência auditiva sensorioneural. Pallister e Opitz (1979) mencionam que mulheres homozigotas, com esta condição, apresentam disgenesia ovariana obrigatória e deficiência auditiva facultativa. A perda auditiva pode ser a única manifestação em homens afetados. Deficiência auditiva do tipo sensorioneural tem-se mostrado como característica marcante neste quadro, com graus que variam de leve ao severo e, alguns casos, com relato de perda auditiva progressiva (Pallister e Opitz 1979, Amor et al 2001, Fiumara et al 2004). Achados neurológicos têm sido observados em alguns indivíduos com síndrome de Perrault e os autores têm questionado se representam, ou não, achados fortuitos (Linssen et al 1994, Gottschalk et 1996, Amor et al 2001). Os Casos 6 e 7 (ambos do sexo feminino) (Tabela 7; Figuras 14 e 16, respectivamente), da presente amostra, apresentaram disgenesia ovariana e deficiência auditiva sensorioneural, características estas, condizentes com a síndrome de Perrault. O Caso 7, além da disgenesia ovariana e deficiência auditiva sensorioneural, apresentou baixa estatura, microcefalia, estrabismo convergente, ptose palpebral à esquerda e atraso no desenvolvimento neuropsicomotor. Baixa estatura e atraso mental já foram observados em indivíduos com a síndrome de Perrault (Nishi et al 1998). Embora achados neurológicos, nesta síndrome, sejam questionados, por alguns autores, como possivelmente ocasionais (Fiumara et al 2004), outros sugerem que esse comprometimento não deve representar uma simples coincidência, mas sim, manifestações pleiotrópicas do gene da síndrome de Perrault (Gottschalk et al 1996). Um irmão (Figura 15; III-1) do Caso 6 (Figura 15; III-2) com deficiência auditiva sensorioneural, considerado igualmente afetado, evidencia modelo de herança autossômico recessivo para o caso em questão. Quadro de displasia craniofrontonasal (condição ligada ao $\mathrm{X}$ dominante), presente na meia-irmã do Caso 7 , não está relacionado à síndrome de Perrault. Pela presença da disgenesia ovariana, essa síndrome deve ser diferenciada de outras que cursam com este manifestação clínica, principalmente a síndrome de Turner. Para os Casos 6 e 7, a exclusão dessa síndrome se fez pela normalidade citogenética e, ainda, pela ausência de achados típicos dessa condição, como linfedema congênito de mãos e pés, pescoço curto e alado. 


\subsubsection{Grupo 2: Indivíduos com deficiência auditiva e envolvimento músculo-esquelético (Casos 8 a 16)}

Foram incluídos, nesse grupo, indivíduos com deficiência auditiva e anomalias músculo-esqueléticas. Espectro oculoauriculovertebral com anomalia radial foi considerado como hipótese diagnóstica para os Casos 8, 9, 10 e 11; síndrome Saethre-Chotzen para o Caso 12; síndrome EEC para o Caso 13; síndrome de Stickler para os Casos 14 e 15 e, síndrome de Marshall, para o Caso 16. Deficiência auditiva condutiva foi observada em 3 casos, sensorioneural em 4, mista em 1 caso e, mista e condutiva em um outro. Os dados referentes a esse grupo encontram-se na Tabela 8. 
TABELA 8: Dados dos indivíduos com deficiência auditiva e envolvimento músculo-esquelético

\begin{tabular}{|c|c|c|c|c|c|c|}
\hline Indivíduo & Sexo & Idade & Sinais clínicos & $\begin{array}{l}\text { Dados gestacionais e perinatais/ } \\
\text { antecedentes pessoais e familiais }\end{array}$ & $\begin{array}{l}\text { Exames complementares e } \\
\text { caracterização da DA }\end{array}$ & $\begin{array}{l}\text { Hipótese diagnóstica } \\
\text { (modelo de herança) }\end{array}$ \\
\hline 08 & M & $36 \mathrm{a} 8 \mathrm{~m}$ & $\begin{array}{l}\text { Coloboma de íris à } \mathrm{D} \text {; hipoplasia da asa nasal } \\
\text { à } \mathrm{E} \text {; orelha } \mathrm{D} \text { pequena, posteriorizada } \mathrm{e} \\
\text { rebaixada com atresia do canal auditivo } \\
\text { externo; agenesia de pavilhão auricular } \mathrm{E} \\
\text { com apêndice cutâneo e canal auditivo } \\
\text { externo normal; deficiência auditiva; } \\
\text { agenesia do 1o raio à } \mathrm{D} \text {; agenesia de } 2 \\
\text { dígitos à E; hipotrofia do membro inferior } \\
\text { E }\end{array}$ & $\begin{array}{l}\text { IMC: 32a / IPC: } 37 \text { a G5P5A0 } \\
\text { Sem intercorrências gestacionais. } \\
\text { Parto normal; gestação a termo. } \\
\text { PN=? EN=? } \\
\text { Pai com DA (adquirida?) a partir dos } 23 \\
\text { anos de idade. } \\
\text { Caso isolado. }\end{array}$ & $\begin{array}{l}\text { Cariótipo: } 46, X Y \\
\text { Avaliação radiológica: à E: hipoplasia } \\
\text { do úmero; ulna curva; fusão de todos } \\
\text { os ossos do carpo; presença de } 3 \\
\text { metacarpos complementados com } 3 \\
\text { segmentos falângicos completos, } \\
\text { sendo que existe um complemento } \\
\text { falângico hipoplásico na porção } \\
\text { medial do 3o dígito. À D: articulação } \\
\text { ulna-umeral lateralmente deslocada; } \\
\text { sinostose rádio-ulnar proximal; } \\
\text { hipoplasia discreta no segmento médio- } \\
\text { distal do rádio e ulna; agenesia de } \\
\text { escafóide; agenesia do lo raio; } \\
\text { clinodactilia do 2o raio. } \\
\text { Avaliação oftalmológica: coloboma de } \\
\text { íris à D } \\
\text { Avaliação audiológica:DA condutiva } \\
\text { moderada bilateral }\end{array}$ & $\begin{array}{l}\text { Espectro oculoauriculovertebral } \\
\text { com anomalia radial } \\
\qquad \text { (HAD) }\end{array}$ \\
\hline
\end{tabular}


Continuação TABELA 8: Dados dos indivíduos com deficiência auditiva e envolvimento músculo-esquelético

\begin{tabular}{|c|c|c|c|c|c|c|}
\hline Indivíduo & Sexo & Idade & Sinais clínicos & $\begin{array}{l}\text { Dados gestacionais e perinatais/ } \\
\text { antecedentes pessoais e familiais }\end{array}$ & $\begin{array}{l}\text { Exames complementares e } \\
\text { caracterização da DA }\end{array}$ & $\begin{array}{l}\text { Hipótese diagnóstica } \\
\text { (modelo de herança) }\end{array}$ \\
\hline 09 & $\mathrm{~F}$ & $12 \mathrm{a} 9 \mathrm{~m}$ & $\begin{array}{l}\text { Falha óssea na regiao posterior do crânio; } \\
\text { assimetria de face; sinofre; estrabismo } \\
\text { divergente; orelhas discretamente } \\
\text { posteriorizadas; deficiência auditiva; } \\
\text { limitação de movimento do pescoço; } \\
\text { implantação baixa de cabelos na região do } \\
\text { pescoço; ombro estreito; anomalia radial } \\
\text { com agenesia do } 2^{\circ} \text { dígito à D e } \mathbf{1}^{\circ} \text { e } \mathbf{2}^{\mathbf{o}} \text { à E; } \\
\text { sindactilia do } 3^{\circ} \text { e } \mathbf{4}^{\circ} \text { dígitos à } \mathbf{E} \text {; hipotonia } \\
\text { generalizada quando bebế; ADNPM }\end{array}$ & $\begin{array}{l}\text { IMC: } 33 \mathrm{a} / \text { IPC: } 41 \mathrm{a} \quad \text { G2P2A0 } \\
\text { Gripe forte no início da gestação. Uso de } \\
\text { analgésicos. } \\
\text { Parto cesáreo; gestação de } 8 \text { meses e } 23 \\
\text { dias. } \\
\mathrm{PN}=2.020 \mathrm{~g}(\mathrm{P}<3) \quad \mathrm{EN}=\text { ? } \\
\text { Nasceu com icterícia. Internada } 1 \text { semana. } \\
\text { Aos } 9 \text { meses de idade, realizou a } 1^{\mathrm{a}} \\
\text { cirurgia de membros superiores. } \\
\text { Aos } 16 \text { a de idade, } \mathrm{A}=146 \mathrm{~cm}(\mathrm{p}<3) \\
\text { Caso isolado. }\end{array}$ & $\begin{array}{l}\text { Cariótipo: 46,XX } \\
\text { Tomografia computadorizada de ossos } \\
\text { temporais: hipogenesia bilateral do } \\
\text { ouvido interno (aplasia de Michel?) } \\
\text { Ecodoppler cardiograma: normal } \\
\text { Avaliação radiológica: coluna cervical - } \\
\text { fusão de vértebras posterior (Klippel- } \\
\text { Feil), escoliose tóraco-lombar de } \\
\text { padrão descompensado (escoliose } \\
\text { idiopática); membro superior D: } \\
\text { agenesia radial, hipoplasia do 2o. } \\
\text { metacarpo, coalisão carpal completa, } \\
\text { arqueamento da ulna para o lado } \\
\text { radial; membro superior E: agenesia } \\
\text { radial, subluxação rádio-carpo, } \\
\text { coalisão ossos do carpo, ausência do } \\
\text { 1o. e 2o. raios com fusão do 4o. e 5o. } \\
\text { metacarpianos e fusão do 3a. e 4a. } \\
\text { falanges proximais } \\
\text { Avaliação audiológica:DA } \\
\text { sensorioneural profunda bilateral }\end{array}$ & $\begin{array}{l}\text { Espectro oculoauriculovertebral } \\
\text { com anomalia radial } \\
\text { (HAD) }\end{array}$ \\
\hline
\end{tabular}


Continuação TABELA 8: Dados dos indivíduos com deficiência auditiva e envolvimento músculo-esquelético

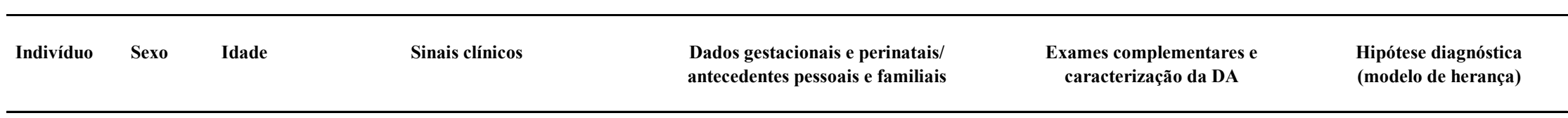

$10 \quad \mathrm{M}$

4a $8 \mathrm{~m}$ Baixa estatura; discreta assimetria de face; IMC: 29a / IPC: 29a

Endas palpebrais oblíquas para baixo; ćlíios Sem intercorrências gestacionais e

longos; estrabismo convergente; nistagmo perinatais.

horizontal; coreoretinite atrófica à $\mathrm{D}$ e Parto cesáreo; gestação a termo.

coloboma do nervo óptico à E; microftalmia $\quad \mathrm{PN}=3.350 \mathrm{~g}(25<\mathrm{p}<50)$

E; base nasal alta; hipoplasia alar; fissura $\mathrm{EN}=49 \mathrm{~cm}(10<\mathrm{p}<25)$

labiopalatina unilateral $\mathrm{D} ; \quad$ orelhas Uma internação, aos 2a de idade, devido

posteriorizadas com baixa implantação; pneumonia.

hélices simplificados; deficiência auditiva; Caso isolado.

anomalia radial à $D$; hipoplasia do $2^{\circ}$

dígito à $\mathrm{D}$; hipoplasia do $1^{\circ}$ raio à $\mathrm{F}$

criptorquidia; ADNPM

facial; hipoplasia malar à $\mathrm{D}$ e do ramo perinatais.

mandibular D; microtia tipo I à E e tipo II à Parto normal; gestação a termo.

$\mathrm{D}$; agenesia do conduto auditivo externo $\mathrm{PN}=3.600 \mathrm{~g}(50<\mathrm{p}<75)$

bilateral; deficiência auditiva; pescoço $\mathrm{EN}=48 \mathrm{~cm}(3<\mathrm{p}<10)$

curto; ombros estreitos; agenesia do $1^{\circ}$ raio Caso isolado.

$\mathrm{D}$; broto digital $\left(1^{\circ}\right.$ raio $)$ à $\mathrm{E}$; háluces

alargados; clinodactilia do $2^{\circ}$ artelho à $E$

hiperextensibilidade atticular; criptorquidia

bilateral
Cariótipo: 46,XY

Tomografia computadorizada crânio-

encefálica: normal

Espectro oculoauriculovertebra com anomalia radial

(HAD)

Tomografia computadorizada de

mastóide: malformação de Mondini

Avaliação oftalmológica: nistagmo

horizontal; coreoretinite atrófica à D e

coloboma do nervo óptico à E;

microftalmia à $\mathrm{E}$

Avaliação radiológica: coluna sem

lteração; hipoplasia acentuda rádio-

alteração, hipoplasia acontuada rádin

ulnar; hipoplasia de metacarpos e

alanges 3-5; agenesia do metacarpo 2

e esboço de falanges do dígito 2; dígito

1 trifalângico

Avaliação audiológica: DA mista

bilateral

Cariótipo: 46,XY

Tomografia computadorizada de

crânio: normal

Avaliação radiológica: retificação da

lordose cervical; hipoplasia/agenesi

corpo vertebral C6; encurtamento

radial bilateral; agenesia 1o. raio

bilateral e clinodactilia 5o. dígito à $\mathrm{E}$

Avaliação audiológica: DA condutiva

moderada bilateral
Espectro oculoauriculovertebral com anomalia radial

$$
\text { (HAD) }
$$


Continuação TABELA 8: Dados dos indivíduos com deficiência auditiva e envolvimento músculo-esquelético

\begin{tabular}{|c|c|c|c|c|c|c|}
\hline Indivíduo & Sexo & Idade & Sinais clínicos & $\begin{array}{l}\text { Dados gestacionais e perinatais/ } \\
\text { antecedentes pessoais e familiais }\end{array}$ & $\begin{array}{l}\text { Exames complementares e } \\
\text { caracterização da DA }\end{array}$ & $\begin{array}{l}\text { Hipótese diagnóstica } \\
\text { (modelo de herança) }\end{array}$ \\
\hline 12 & M & $5 \mathrm{a}$ & $\begin{array}{l}\text { Plagiocefalia; fendas palpebrais oblíquas para } \\
\text { baixo; ptose palpebral à E; orelha D } \\
\text { posteriorizada e com baixa implantação; } \\
\text { microtia à E com agenesia CAE; deficiência } \\
\text { auditiva; torcicolo congênito; hérnia } \\
\text { umbilical; hipoplasia do polegar E; } \\
\text { braquidactilia } 5^{\circ} \text { dígitos; pés planos e } \\
\text { discretamente tortos; háluces alargados; } \\
\text { clinodactilia } 2^{\circ} \text { artelhos ADNM leve }\end{array}$ & $\begin{array}{l}\mathrm{IMC}=29 \mathrm{a} / \mathrm{IPC}=29 \mathrm{a} \quad \mathrm{G} 3 \mathrm{P} 3 \mathrm{~A} 0 \\
\text { Durante toda a gestação, apresentou } \\
\text { desmaios, tontura e cefaléia. } \\
\text { Parto cesáreo; gestação de } 36 \text { semanas. } \\
\mathrm{PN}=3.050 \mathrm{~g}(25<\mathrm{p}<50) \quad \mathrm{EN}=\text { ? } \\
\text { Permaneceu } 4 \text { dias na incubadora. } \\
\text { Vários episódios de otites e amigdalites. } \\
\text { Bisavô materno, avó materna, mãe, } 1 \text { tio } \\
\text { materno, em } 2^{\circ} \text { grau, } 4 \text { tios maternos, } 2 \\
\text { primas maternas e } 1 \text { irmã igualmente } \\
\text { afetados. }\end{array}$ & $\begin{array}{l}\text { Cariótipo: } 46, X Y \\
\text { Avaliação ortopédica: torcicolo } \\
\text { congênito } \\
\text { Avaliação audiológica:DA condutiva } \\
\text { moderada à D e severa à E }\end{array}$ & $\begin{array}{c}\text { Síndrome de Sathre-Chotzen } \\
\text { (HAD) }\end{array}$ \\
\hline 13 & $\mathrm{~F}$ & $31 \mathrm{a}$ & $\begin{array}{l}\text { Deficiência visual à } D \text {; obstrução do canal } \\
\text { lacrimal bilateralmente; fissura labiopalatina } \\
\text { bilateral; deficiência auditiva; ectrodactilia } \\
\text { de mãos e pés; pele e cabelos secos; unhas } \\
\text { displásicas }\end{array}$ & $\begin{array}{l}\mathrm{IMC}=25 \mathrm{a} / \mathrm{IPC}=? \\
\text { Estresse emocional. } \\
\text { Parto normal; gestação a termo. } \\
\mathrm{PN}=\text { ? EN=? } \\
\text { Otites de repetição. } \\
\text { Aos 3a de idade, realizou cirurgia canal } \\
\text { lacrimal. } \\
\text { Pai e } 1 \text { filho igualmente afetados. }\end{array}$ & $\begin{array}{l}\text { Cariótipo: } 46, X X \\
\text { Avaliação oftalmológica: deficiência } \\
\text { visual à D, em decorrência de } \\
\text { infecções oculares (úlcera de córnea) } \\
\text { Avaliação audiológica:DA mista } \\
\text { severa à D e DA condutiva } \\
\text { moderada à } \mathbf{E}\end{array}$ & $\begin{array}{l}\text { Síndrome EEC } \\
\text { (HAD) }\end{array}$ \\
\hline
\end{tabular}


Continuação TABELA 8: Dados dos indivíduos com deficiência auditiva e envolvimento músculo-esquelético

\begin{tabular}{|c|c|c|c|c|c|c|}
\hline Indivíduo & Sexo & Idade & Sinais clínicos & $\begin{array}{l}\text { Dados gestacionais e perinatais/ } \\
\text { antecedentes pessoais e familiais }\end{array}$ & $\begin{array}{l}\text { Exames complementares e } \\
\text { caracterização da DA }\end{array}$ & $\begin{array}{l}\text { Hipótese diagnóstica } \\
\text { (modelo de herança) }\end{array}$ \\
\hline 14 & $\mathrm{~F}$ & $4 \mathrm{a} 1 \mathrm{~m}$ & $\begin{array}{l}\text { Fácies arredondado; hipoplasia de face } \\
\text { média; olhos grandes e proeminentes; pontes } \\
\text { supra-orbitárias rasas; epicanto bilateral; } \\
\text { miopia; catarataà D; nariz pequeno com base } \\
\text { nasal achatada; hipoplasia asa nasal; } \\
\text { deficiência auditiva; hiperelasticidade } \\
\text { articular, leve ADNM }\end{array}$ & $\begin{array}{l}\text { IMC: } 23 \mathrm{a} \text { / IPC: } 28 \mathrm{a} \quad \text { G2P2A0 } \\
\text { Hipertensão arterial durante período } \\
\text { gestacional. Não soube referir sobre } \\
\text { medicamento. } \\
\text { Parto cesáreo; gestação a termo. Teve } \\
\text { eclâmpsia. } \\
\mathrm{PN}=3.050 \mathrm{~g}(\mathrm{p}=25) \\
\mathrm{EN}=52 \mathrm{~cm} \text { ( }=75) \\
\text { Dificuldade respiratória ao nascimento. } \\
\text { Permaneceu na incubadora por } 7 \text { dias. } \\
\text { Avô paterno e vários tios paternos, em } 2^{\circ} \\
\text { grau, com miopia alta; } 3 \text { primos paternos, } \\
\text { em } 2^{\circ} \text { grau, com cegueira (descolamento } \\
\text { de retina); } 1 \text { prima paterna, em } 2^{\circ} \text { grau, } \\
\text { com miopia alta e pai com olhos grandes, } \\
\text { base nasal baixa, discreta hipoplasia de } \\
\text { face média e miopia baixa. }\end{array}$ & $\begin{array}{l}\text { Cariótipo: } 46, \mathrm{XX} \\
\text { Avaliação oftalmológica: catarate à D; } \\
\text { miopia de } 17 \mathrm{di} \text { à E. } \\
\text { Reavaliação oftalmológica, aos 7a 6m: } \\
\text { perda visual à D e miopia de } 17 \mathrm{di} \text { à E. } \\
\text { Prótese ocular à D em setembro/2002. } \\
\text { Estudo molecular da família: presença } \\
\text { de mutação c.556G>T; p.Gli86X em } \\
20 \text { indivíduos afetados } \\
\text { Avaliação audiológica:DA } \\
\text { sensorioneural leve à D }\end{array}$ & $\begin{array}{l}\text { Síndrome de Stickler } \\
\text { (HAD) }\end{array}$ \\
\hline 15 & M & 3a $11 \mathrm{~m}$ & $\begin{array}{l}\text { Hipoplasia malar; base nasal baixa; nariz } \\
\text { pequeno e dorso-fletido; narinas } \\
\text { antevertidas; epicanto bilateral; miopia alta; } \\
\text { filtro longo; deficiência auditiva; } \\
\text { hiperextensibilidade articular. }\end{array}$ & $\begin{array}{l}\text { IMC: } 21 \mathrm{a} / \text { IPC: } 25 \mathrm{a} \quad \text { G1P1A0 } \\
\text { Sem intercorrências gestacionais e } \\
\text { perinatais. } \\
\text { Parto cesáreo; gestação a termo. } \\
\mathrm{PN}=3.300 \mathrm{~g}(25<\mathrm{P}<50) \\
\mathrm{EN}=48 \mathrm{~cm}(3<\mathrm{P}<10) \\
\text { Miopia diagnosticada aos } 2 \text { anos de idade. } \\
\text { Uso de óculos. } \\
\text { Caso isolado. }\end{array}$ & $\begin{array}{l}\text { Avaliação oftalmológica: miopia (8di à } \\
\text { D e 10di à esquerda) } \\
\text { Avaliação audiológica:DA } \\
\text { sensorioneural severa bilteral }\end{array}$ & $\begin{array}{c}\text { Síndrome de Stickler } \\
\text { (HAD) }\end{array}$ \\
\hline
\end{tabular}


Continuação TABELA 8: Dados dos indivíduos com deficiência auditiva e envolvimento músculo-esquelético

\begin{tabular}{|c|c|c|c|c|c|c|}
\hline Indivíduo & Sexo & Idade & Sinais clínicos & $\begin{array}{l}\text { Dados gestacionais e perinatais/ } \\
\text { antecedentes pessoais e familiais }\end{array}$ & $\begin{array}{l}\text { Exames complementares e } \\
\text { caracterização da DA }\end{array}$ & $\begin{array}{l}\text { Hipótese diagnóstica } \\
\text { (modelo de herança) }\end{array}$ \\
\hline 16 & $\mathrm{~F}$ & 22a $11 \mathrm{~m}$ & $\begin{array}{l}\text { Baixa estatura; fronte estreita; retração e } \\
\text { hipoplasia da face média; olhos grandes; } \\
\text { nistagmo horizontal; miopia alta; perda } \\
\text { visual à D; nariz pequeno, dorso-fletido e } \\
\text { com base baixa; narinas antevertidas; filtro } \\
\text { longo e hipoplásico; palato alto e estreito; } \\
\text { queixo pequeno; implantação baixa de } \\
\text { orelhas; deficiência auditiva; dígitos } \\
\text { longos; falanges distais alargadas; } \\
\text { limitação na flexão de dígitos; ADNPM } \\
\text { leve }\end{array}$ & $\begin{array}{l}\text { IMC: } 21 \mathrm{a} / \mathrm{IPC}: 23 \mathrm{a} \quad \mathrm{G} 2 \mathrm{P} 2 \mathrm{~A} 0 \\
\text { Sem intercorrências gestacionais e } \\
\text { perinatais. } \\
\text { Parto normal; gestação a termo. } \\
\mathrm{PN}=3.370 \mathrm{~g}(\mathrm{P}=50) \quad \mathrm{EN}=\text { ? } \\
\text { Perda visual à } \mathrm{D} \text { (descolamento de retina), } \\
\text { aos 4a de idade. } \\
\text { Aos 22a } 11 \mathrm{~m}: \mathrm{A}=150 \mathrm{~cm}(\mathrm{p}<3) \\
\text { Caso isolado. }\end{array}$ & $\begin{array}{l}\text { Cariótipo: 46,XX } \\
\text { Avaliação oftalmológica: miopia de } 26 \\
\text { di à E } \\
\text { Avaliação audiológica: DA } \\
\text { sensorioneural profunda bilateral }\end{array}$ & $\begin{array}{c}\text { Síndrome de Marshall } \\
\text { (HAD) }\end{array}$ \\
\hline
\end{tabular}

M=masculino; F=feminino; a/m=idade em ano(s) e mês(es) na primeira avaliação; IMC=idade materna na concepção; I PC=idade paterna na concepcão; $\quad \mathrm{G}_{-} \mathrm{P} \_\mathrm{A}=\mathrm{n}^{\circ}$ de gestações, partos e abortos; PN=peso ao nascimento; EN=estatura ao nascimento; P=peso; $\mathrm{A}=$ =altura; p=percentil; $\mathrm{DA}=$ =deficiência auditiva; $\mathrm{D}=$ =direita; $\mathrm{E}=$ =esquerda; $\mathrm{ADNM}=$ atraso no desenvolvimento neuromotor; $\mathrm{ADNPM}=$ atraso no desenvolvimento neuropsicomotor; $\mathrm{HAD}=$ herança autossômica dominante 

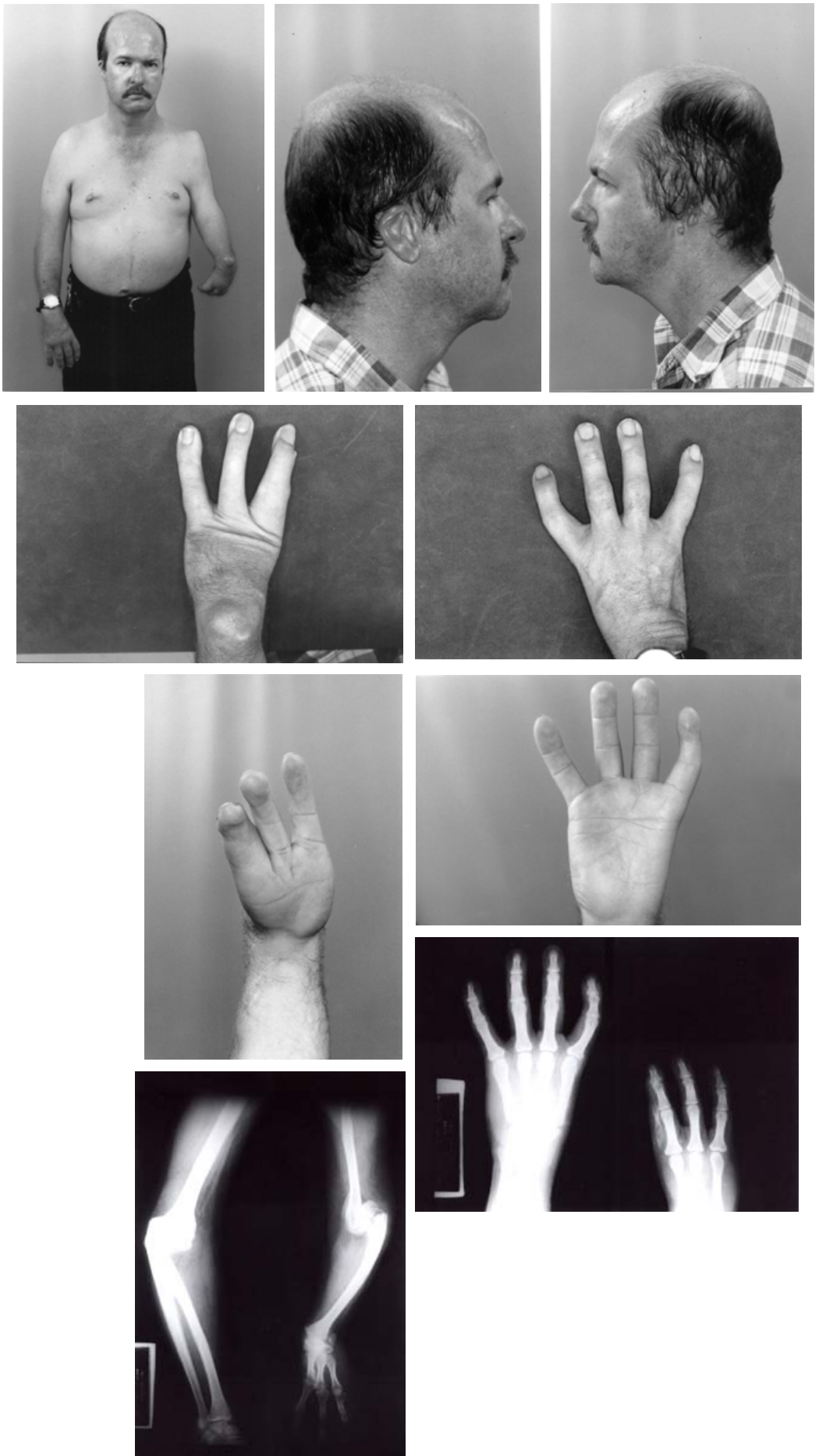

FIGURA 17: Aspectos clínicos e radiológicos do Caso 08 

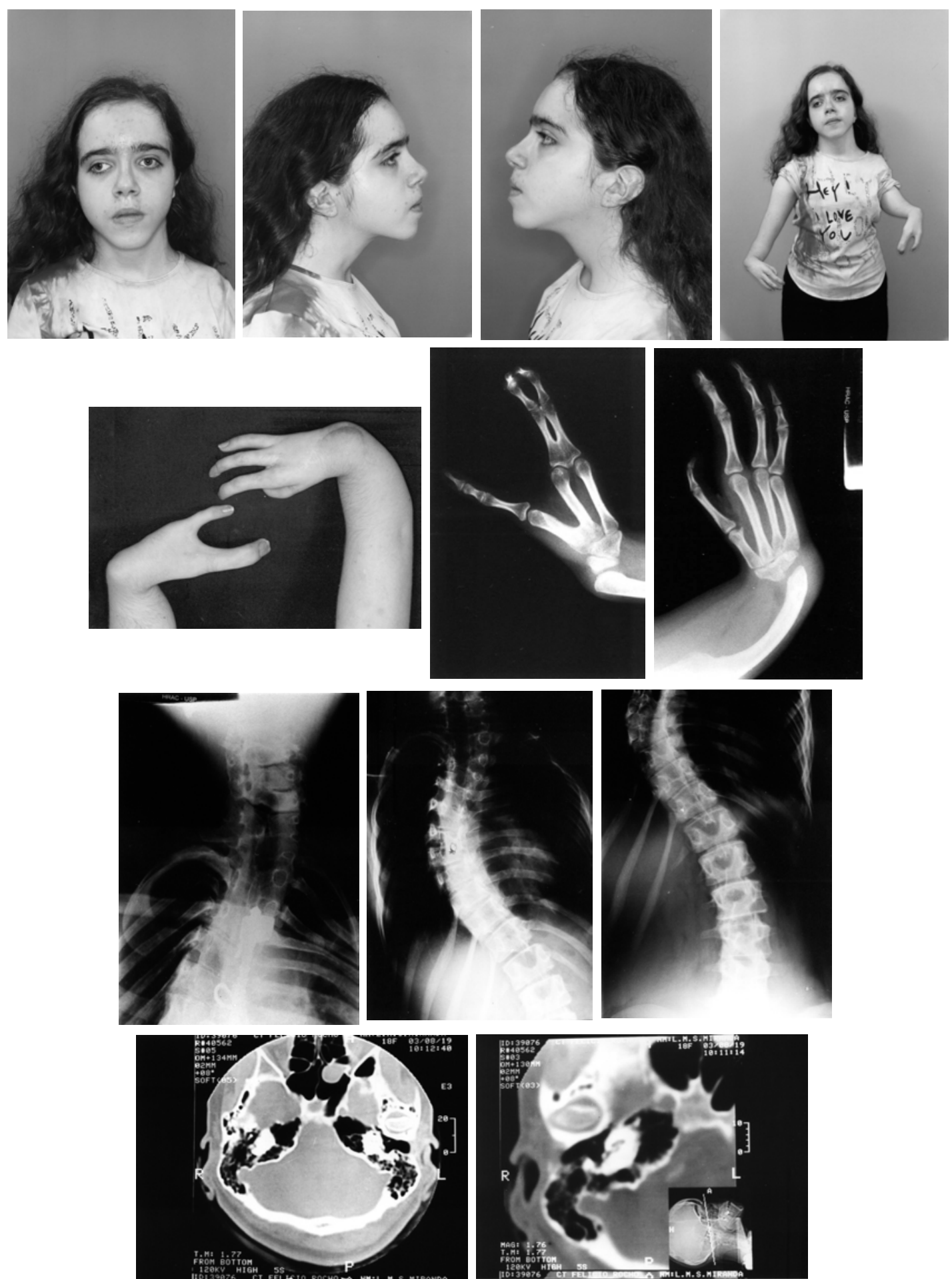

FIGURA 18: Aspectos clínicos, radiológicos e tomográficos do Caso 09 

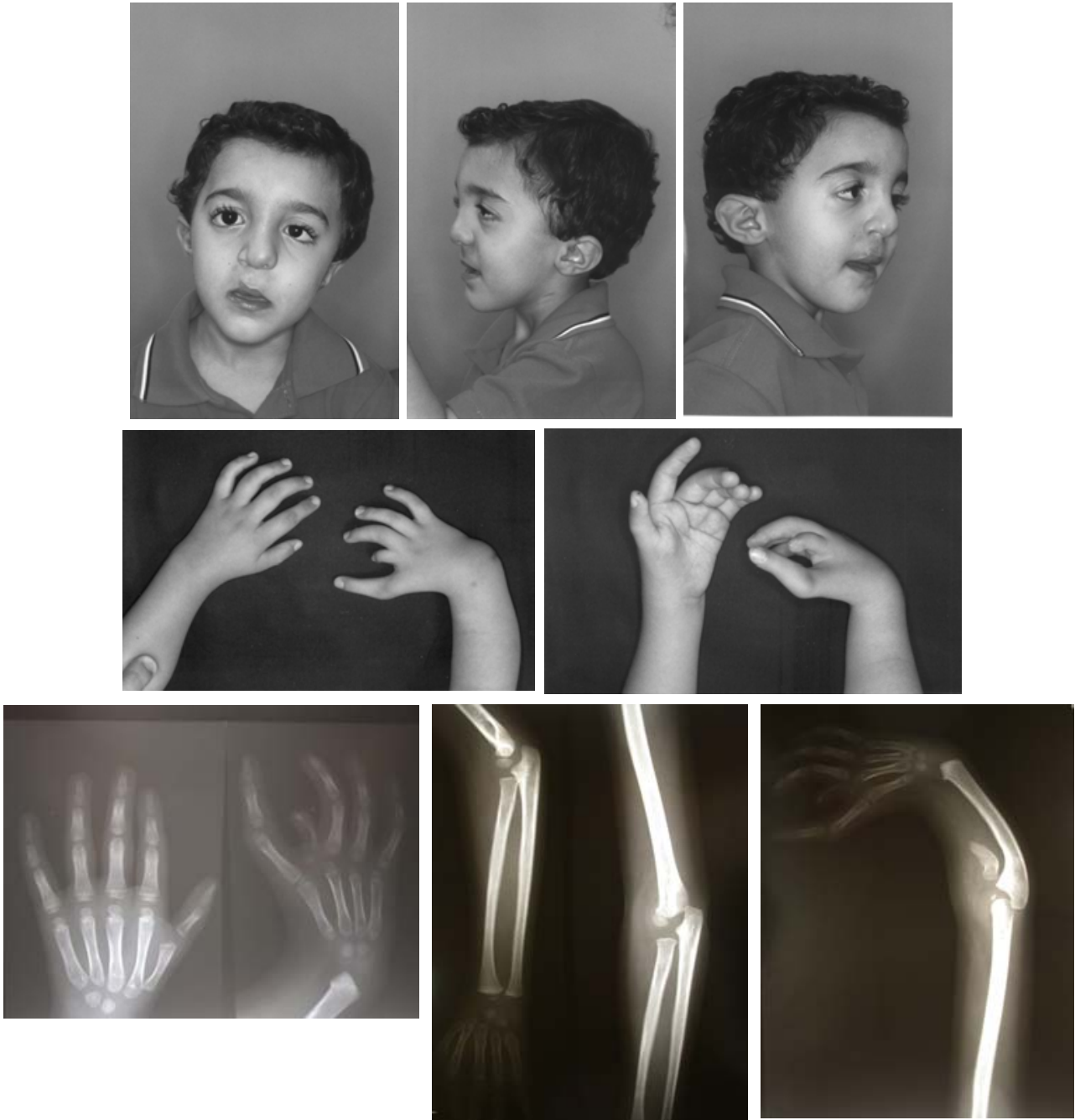

FIGURA 19: Aspectos clínicos e radiológicos do Caso 10 

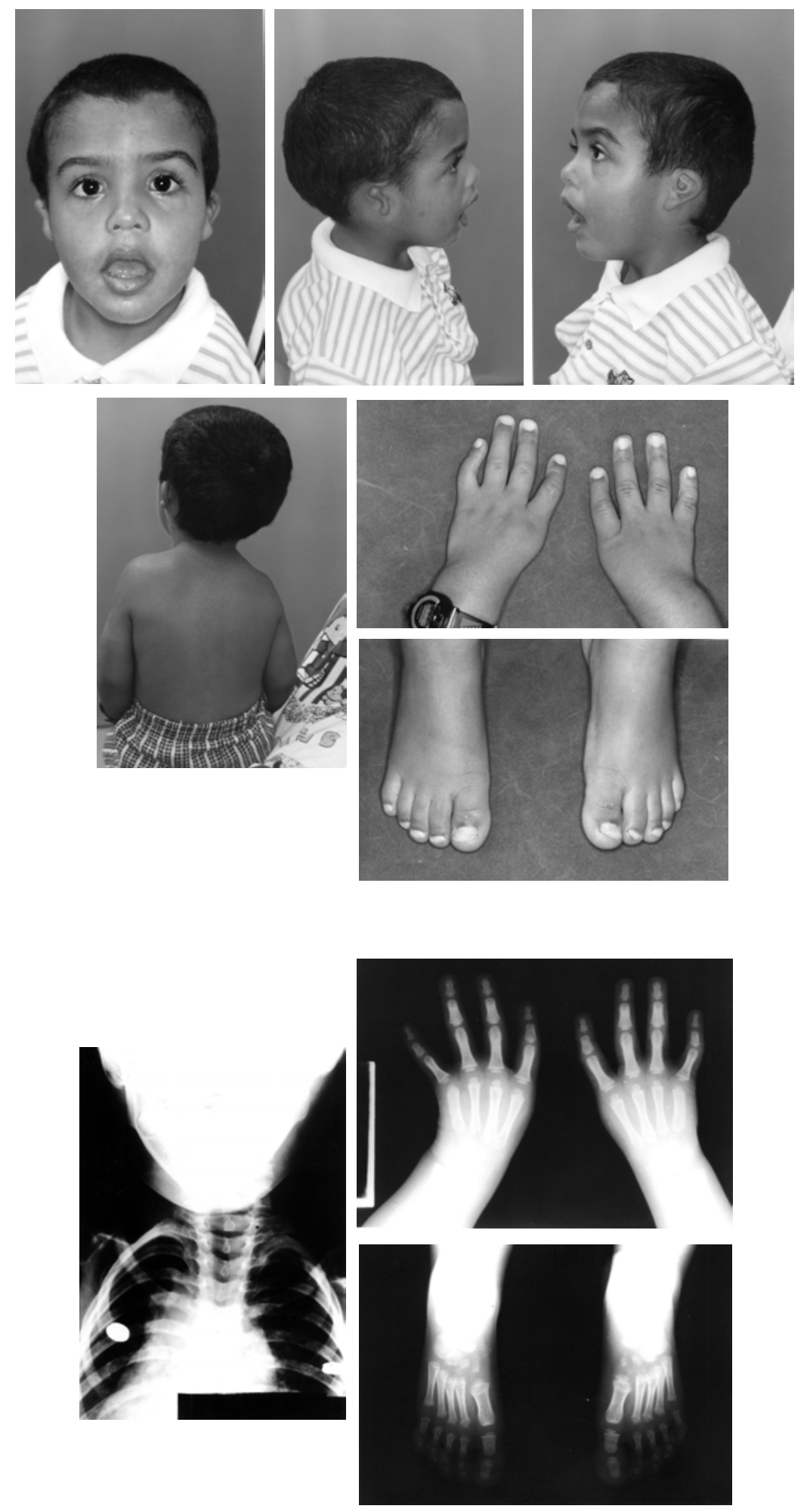

FIGURA 20: Aspectos clínicos e radiológicos do Caso 11 

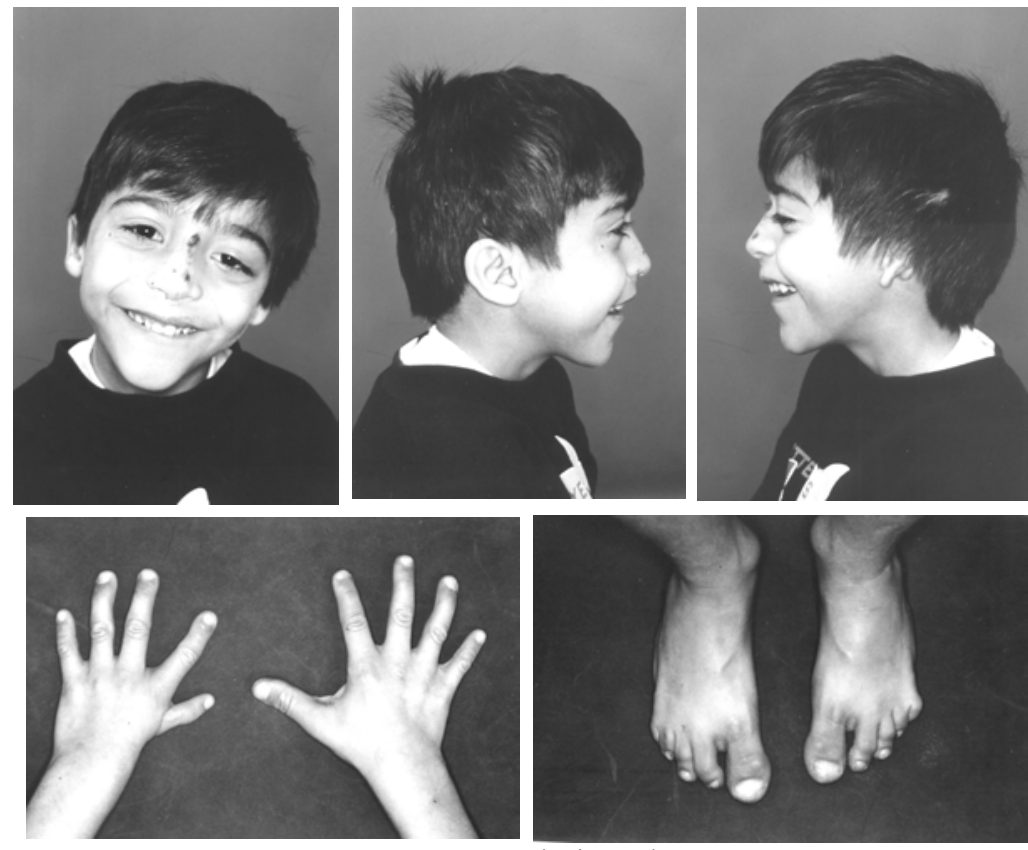

FIGURA 21: Aspectos clínicos do Caso 12

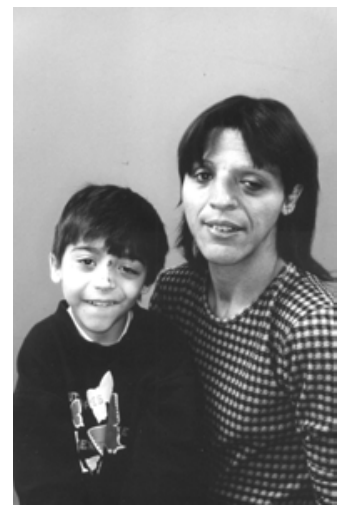

FIGURA 22: Aspectos clínicos da genitora do Caso 12

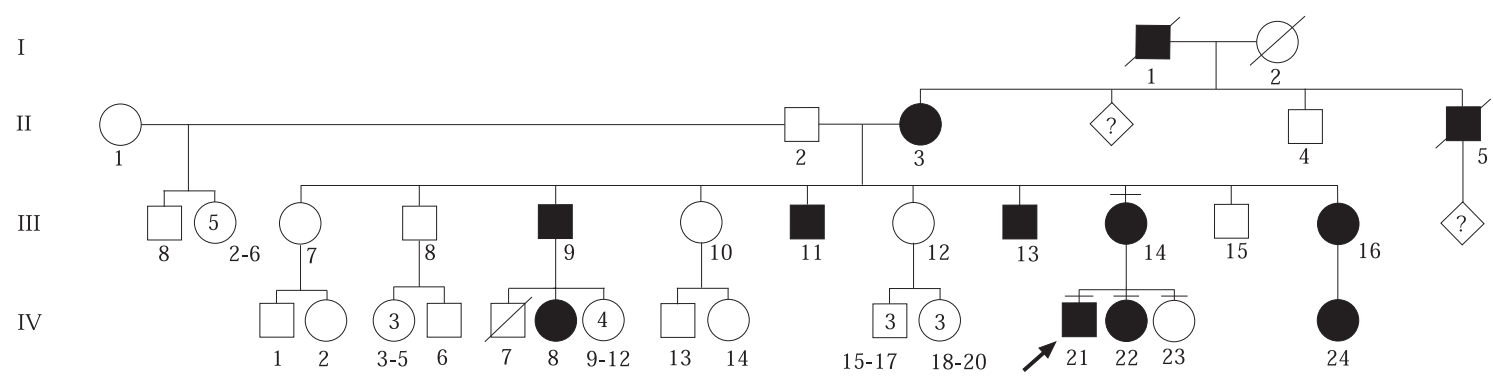

FIGURA 23: Heredograma da família do Caso 12 

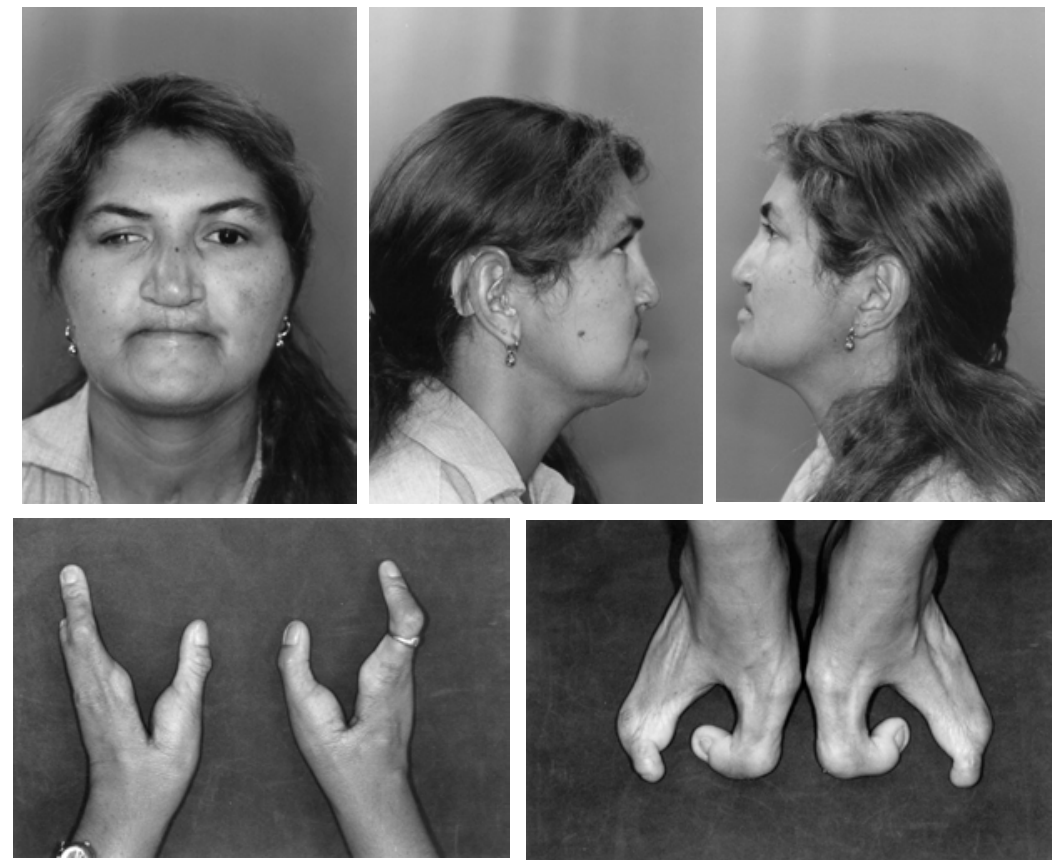

FIGURA 24: Aspectos clínicos do Caso 13

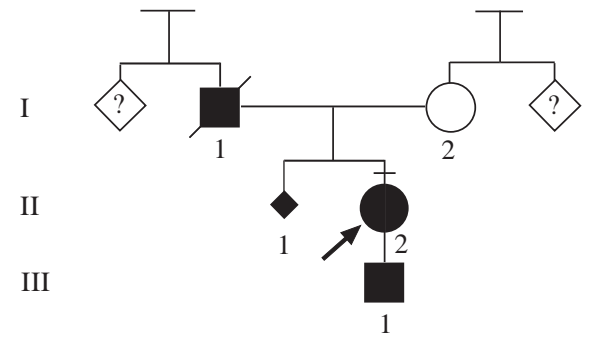

FIGURA 25: Heredograma da família do Caso 13 

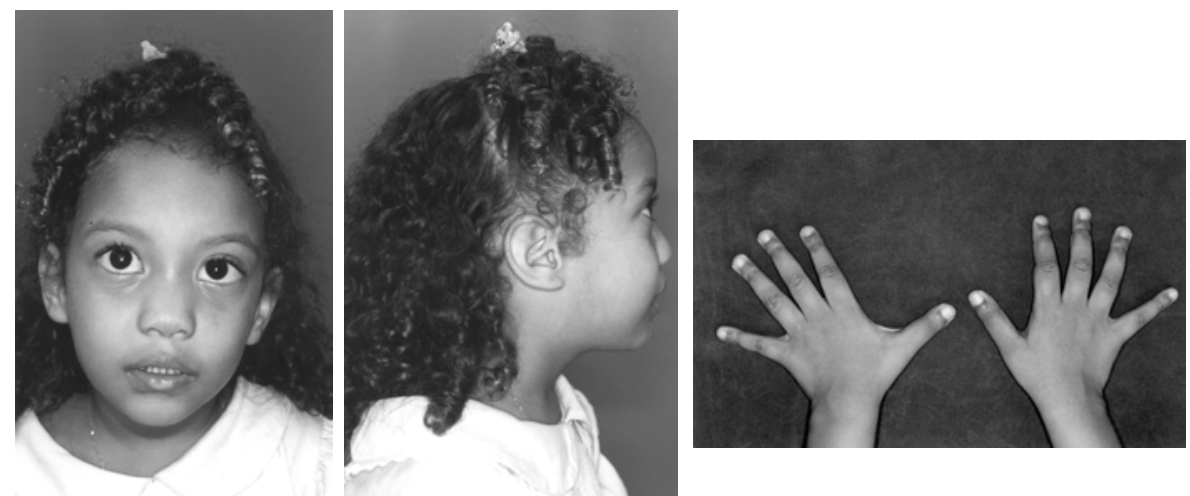

FIGURA 26: Aspectos clínicos do Caso 14

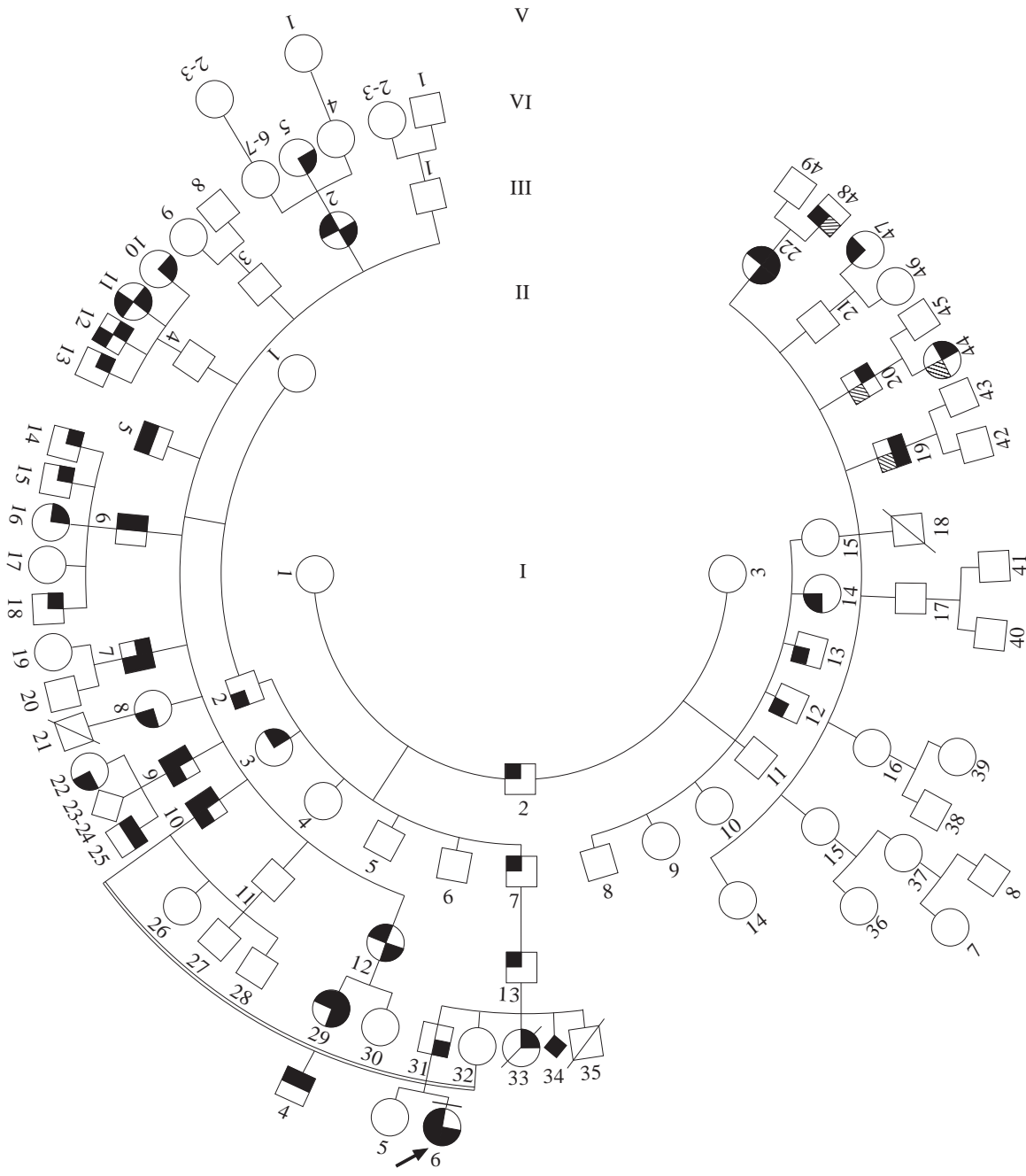

Miopia

$\square$ Descolamento de retina - Fissura de palato

○. Anomalia esquelética (2)

FIGURA 27: Heredograma da família do Caso 14 

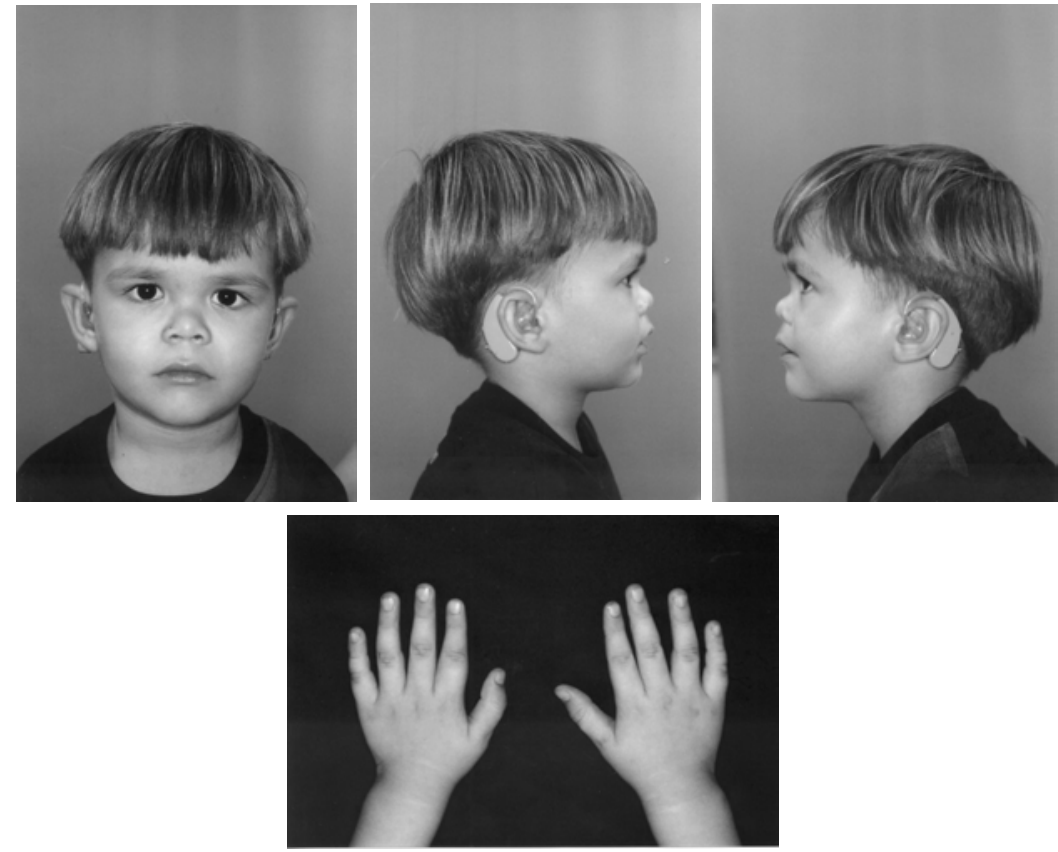

FIGURA 28: Aspectos clínicos do Caso 15
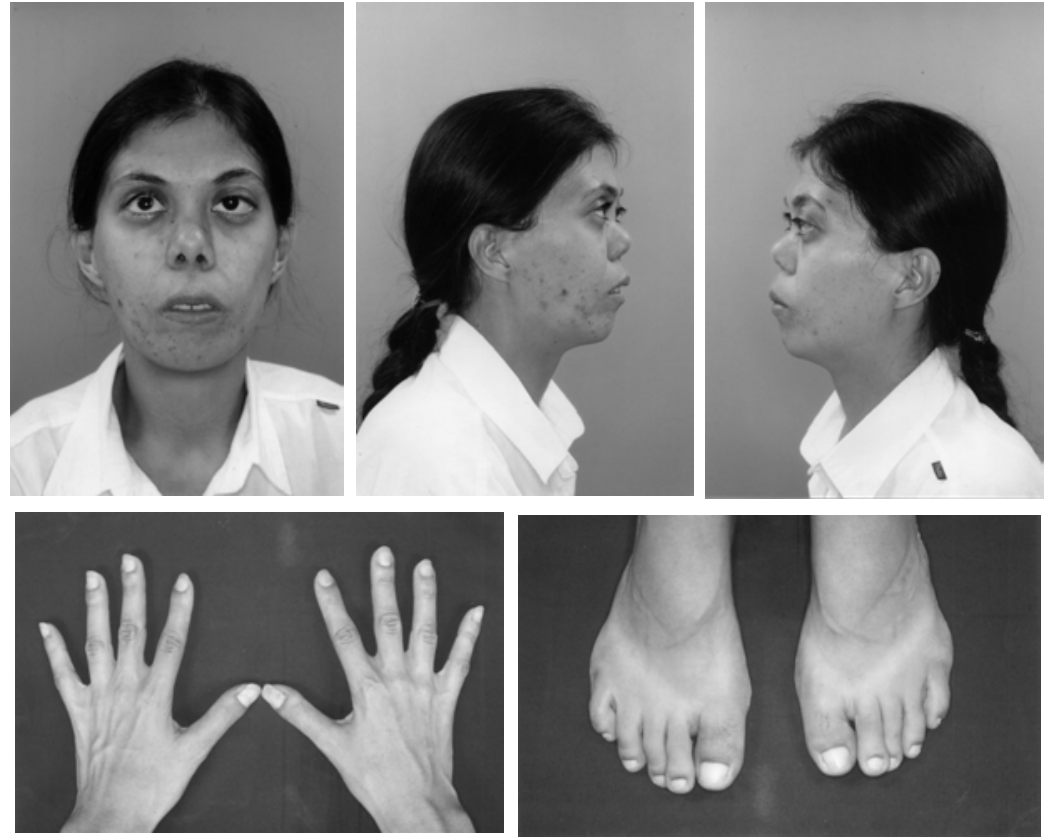

FIGURA 29: Aspectos clínicos do Caso 16 
O sistema músculo-esquelético é formado pelo esqueleto, pelos músculos, tendões, ligamentos e outros componentes das articulações. O esqueleto provê força, estabilidade e uma base de sustentação para que os músculos trabalhem e produzam o movimento; os ossos também servem de escudos para proteger os delicados órgãos internos e, este sistema, como um todo, é responsável pela postura e pelos movimentos. Dezenas são as síndromes envolvendo deficiência auditiva e anomalias músculo-esqueléticas. Gorlin et al (1995) citam 87 síndromes pertinentes.

No presente grupo, 9 indivíduos apresentaram deficiência auditiva com envolvimento músculo-esquelético (Tabela 8), compreendendo diferentes níveis de acometimento. Espectro oculoauriculovertebral com anomalia radial, síndrome de Saethre-Chotzen, síndrome EEC, síndrome de Stickler e síndrome de Marshall foram os diagnósticos estabelecidos neste grupo.

Os Casos 8, 9, 10 e 11 (Tabela 8; Figuras 17, 18, 19 e 20, respectivamente), da presente amostra, apresentaram anomalias faciais decorrentes do envolvimento de primeiro e segundo arcos branquiais, compatíveis com o espectro oculoauriculovertebral (EOAV). Em associação, estes indivíduos apresentaram defeitos radiais variáveis. Assim como nos indivíduos descritos na literatura, a extrema variabilidade clínica foi característica nos indivíduos com o EOAV associado à anomalia radial, da presente casuística, tanto no comprometimento facial quanto radial. Perda auditiva condutiva e sensorioneural, observada nos 4 indivíduos em questão, têm sido descritas na literatura. Revisão recente sobre EOAV e anomalia radial mostrou que perda auditiva, embora nem sempre especificado o tipo, estava presente em $86 \%$ dos indivíduos com este quadro (Vendramini, 2006). Este mesmo autor, avaliando, ainda, do ponto de vista clínico e audiológico, 14 indivíduos com essa mesma condição, encontrou deficiência auditiva sensorioneural em 46.4\% dos casos e condutiva, em 28.6\%. Embora na literatura não haja consenso quanto a este quadro representar, ou não, uma condição distinta, o autor concluiu que o EOAV associado à anomalia radial é uma síndrome distinta e que deficiência auditiva, do tipo sensorioneural, faz parte desse espectro. Relato de mãe e filha afetadas sugere a hipótese de modelo de herança autossômica dominante (Moeschler e Clarren 1982). Os Casos 8 a 11 são isolados e, possivelmente, decorrentes de mutação nova. A variabilidade clínica do EOAV acarreta dificuldade diagnóstica, principalmente nos casos com envolvimento radial e, por esta razão, síndromes que cursam com defeito radial e deficiência auditiva, tais como: 
síndrome Townes-Brocks (OMIM 107480); síndrome de Nager (OMIM-154400); síndrome radial renal (OMIM 179280); síndrome Okihiro (OMIM 607323); displasia facioauriculoradial (OMIM 171480) e anemia de Fanconi (OMIM 227650) foram consideradas no diagnóstico diferencial dos indivíduos 8, 9, 10 e 11 da presente casuística e, excluídas pelo padrão de comprometimento craniofacial. Cabe ressaltar que o Caso 11 apresenta alterações de raio 1 similar às encontradas nos indivíduos com síndrome de Nager; porém, a ausência de disostose mandibulofacial, o diferencia desta. Estudos referentes à investigação molecular têm identificado mutações no gene SALL1 em indivíduos com a síndrome de Townes-Brocks (Kohlhase et al 1998) e mutação no gene SALL4, em indivíduos com a síndrome de Okihiro (Kohlhase et al 2002, Terhal et al 2006). Considerando a sobreposição clínica dessas síndromes com o EOAV associado à anomalia radial, investigação dessas mutações deve ser incentivada nos indivíduos com esta condição.

Síndrome de Saethre-Chotzen (OMIM 101400) foi o diagnóstico estabelecido para o Caso 12 (Tabela 8; Figura 21) da presente amostra. Esse quadro apresenta modelo de herança autossômica dominante, com penetrância completa e expressividade variável (Niemann-Seyde et al 1991, Gorlin et al 1995) e, é caracterizado por amplo e variável padrão de malformações, incluindo craniosinostose, fronte estreita, assimetria facial, ptose palpebral, desvio do septo nasal, braquidactilia, sindactilia cutânea parcial, clinodactilia de $5^{\circ}$ dígito e hálux valgo e alargado. Variabilidade fenotípica, intra e interfamilial são observadas nesta síndrome (Chung et al 2002, Kress et al 2006). O Caso 12 apresenta comprometimento facial leve, porém característico da síndrome de Saethre-Chotzen. O padrão de alteração de extremidade (hipoplasia do raio 1), embora atípico, foi observado em vários afetados de uma família, com esta condição, descrita por Friedman et al (1977). Microtia, sinal observado no Caso 12, não é citado nesta síndrome, podendo representar um achado não relacionado. A história familial do Caso 12 (Figura 23; IV-21) mostrou, ainda, outros 11 indivíduos afetados, em 4 gerações, caracterizando modelo de herança autossômica dominante (Figura 23). Anomalias craniofaciais e de extremidades, típicas da síndrome em questão, foram observadas na genitora (Figura 23; III-14) e em uma irmã (Figura 23; IV-22). Perda auditiva condutiva foi constatada na genitora e, atraso mental grave foi referido em um dos tios (Figura 23; III-13). Os demais indivíduos não foram avaliados. Segundo Gorlin et al (1995), 55\% dos indivíduos com síndrome de Saethre-Chotzen 
apresentam graus variados de deficiência auditiva condutiva. Já, perda auditiva mista e sensorioneural têm sido raramente observadas (Ensink et al 1996, Lee et al 2002). Heterogeneidade genética tem sido observada na síndrome de Saethre-Chotzen pela identificação de diferentes mutações no gene TWIST $(7 \mathrm{p} 21)$ e, ainda, mais recentemente, por mutações intragênicas nos genes FGFR2 (10q26) e FGFR3 (4p16) em indivíduos com esta condição (Paznekas et al 1998, Passos-Bueno et al 1999, Rice et al 2000, El Ghouzzi et al 2001, Chun et al 2002). Estas mutações intragênicas têm, ainda, sido relacionadas com outras condições que cursam com craniosinostoses (Reardon et al 1997, Paznekas et al 1998, Passos-Bueno et al 1999, Rice et al 2000, El Ghouzzi et al 2001, Chun et al 2002, Kress et al, 2006). Envolvimento de membros é achado comum na maioria dessas síndromes e, a sobreposição de sinais clínicos entre essas condições e a presença de mutações nos genes TWIST, FGFR2 e FGFR3 sugerem que um caminho molecular comum esteja envolvido na modulação do desenvolvimento craniofacial e de membros em humanos (Reardon et al 1997, Paznekas et al 1998, Passos-Bueno et al 1999, Rice et al 2000, El Ghouzzi et al 2001, Chun et al 2002). Considerando o acima exposto, síndromes que cursam com craniosinostose, tais como síndrome de Crouzon (OMIM 123500), síndrome de Jackson-Weiss (OMIM 123150), síndrome de Pfeiffer (OMIM 101600), síndrome de Apert (OMIM 101200) e síndrome de Muenke (OMIM 602849) devem ser consideradas no diagnóstico diferencial para o Caso 12. Estudo molecular, nessa família, é de extrema relevância.

Síndrome EEC (E=ectrodactyly; E=ectodermal dysplasia; C=clefting OMIM-129900), foi o diagnóstico estabelecido para o Caso 13 (Tabela 8; Figura 24). Essa síndrome é caracterizada por displasia ectodérmica, envolvendo pele, cabelos, unhas e dentes; obstrução do ducto naso-lacrimal; fissura labiopalatina; ectrodactilia de mãos e pés e anomalias urogenitais. Perda auditiva condutiva tem sido observada em cerca de 15\% dos indivíduos com EEC (Rodini e Richieri-Costa 1990, Roelfsema e Cobben 1996). Penetrância reduzida e alta variabilidade clínica inter e intrafamilial foram sugeridas por Mckusick (1992) e Barrow et al (2002). Casos esporádicos, transmissão pai-filho e, menos freqüentemente, irmãos afetados, com pais aparentemente normais, sugerem heterogeneidade genética para essa a síndrome EEC (Gorlin et al, 1995). Três loci têm sido responsabilizado pelo fenótipo da síndrome EEC: 7q11.2-q21.3, D19S894 e D19S416 (cromossomo 19) e 3q27. Estudos moleculares têm mostrado que a maioria dos casos é secundária às mutações no gene 
p63 (TP63). O Caso 13, da presente casuística, apresentou fenótipo facial e esquelético típico da síndrome EEC. Deficiência auditiva mista à direita e condutiva à esquerda estava presente neste indivíduo. Embora a maioria dos casos com síndrome EEC, relatados em literatura, apresente deficiência auditiva condutiva, o tipo sensorioneural foi referido por Wildervanck (1963), ao descrever dois irmãos afetados. História familial do Caso 13 mostrou afetados em 3 gerações (Figura 25; I-1, II-2 e III-1), sugerindo padrão de herança autossômica dominante, porém, estes indivíduos não foram clínica e audiologicamente avaliados. Em relação ao diagnóstico diferencial, quadros envolvendo alterações esqueléticas e displasia ectodérmica, tais como síndrome Rapp-Hodgkin (OMIM 129400), síndrome Hay-Wells ou síndrome AEC (OMIM 106260), síndrome Rosselli-Gulienetti (OMIM 225000) foram considerados e excluídos pelas diferenças no padrão de envolvimento de extremidades.

Os Casos 14, 15 e 16 (Tabela 8; Figuras 26, 28 e 29, respectivamente) apresentaram anomalias orofaciais e oculares similares e compatíveis com a síndrome de Stickler (OMIM 108300). Esta condição é caracterizada, clinicamente, pela combinação de anomalias orofaciais (hipoplasia malar, base nasal larga, fissura de palato e micrognatia), anomalias oculares (catarata, miopia, degeneração do vítreo e descolamento de retina) e anomalias esqueléticas (displasia epifisária e degeneração prematura das articulações). Importante enfatizar que as anomalias oculares, neste quadro, são graves e de caráter progressivo, podendo levar à perda visual ainda na infância. Herança autossômica dominante e alta variabilidade clínica, tanto intra quanto interfamilial, é característica desta síndrome (Stickler et al 1965, 2001; Liberfarb et al 2003). Heterogeneidade genética tem sido observada nesta condição. Cerca de $75 \%$ dos indivíduos com síndrome de Stickler apresentam mutações no gene COL2A1 (12q13), que codifica o colágeno tipo II (Ahmad et al 1991, Nishimura et al 2005); 20\% são causados por mutações nos genes COL11A1 (1p21) e COL11A2 (6p21), os quais codificam o colágeno tipo XI (Vikkula et al 1995, Poulson et al 2004) e os 5\% restantes, têm causa desconhecida (Martin et al 1999). Baseando-se nos estudos moleculares e no fenótipo ocular, a síndrome de Stickler é classificada em três tipos: tipo I (OMIM 108300) que se caracteriza pela presença de vítreo membranoso e é causada por mutações no COL2A1; tipo II (síndrome de Stickler ocular - OMIM 604841), caracterizada pela presença de vítreo em forma de contas e causada por mutações no 
COL11A1 e, tipo III (síndrome de Stickler não ocular - OMIM 184840), que se caracteriza por normalidade ocular e é causada por mutação no gene COL11A2. Trabalhos mais recentes, sobre a síndrome de Stickler, têm enfatizado a perda auditiva, principalmente a do tipo sensorioneural, como achado importante do quadro fenotípico (Admiraal et al 2002). Esses autores comentaram que perda auditiva sensorioneural ocorre em 50 a $60 \%$ dos indivíduos com o tipo I; em 80 a 100\% dos indivíduos com o tipo II (mais grave e progressiva) e que, no tipo III é uma característica típica e com $100 \%$ de penetrância. Já, a perda auditiva condutiva tem sido mencionada como característica secundária à fissura de palato (Snead e Yates 1999, Admiraal et al 2000). Os Casos 14 e 15, da presente amostra, apresentaram sinais orofaciais e oculares (Tabela 8) característicos da síndrome de Stickler. As anomalias oculares mais graves foram observadas no Caso 14 (Figura 26), com conseqüente perda visual precoce. Perda auditiva sensorioneural assimétrica e de diferentes graus foi constatada nos dois casos. História familial do Caso 14 (Figura 27; V-6) mostrou-se positiva para sinais orofaciais e oculares em 46 indivíduos distribuídos em cinco gerações (Figura 27). Variabilidade fenotípica intrafamilial foi observada. Trabalho recente de Zechi-Ceide (2006) mostrou que 20 dos 46 indivíduos, desta família, apresentavam mutação no COL2A1 (c.556G>T; p.Gli86X), compatível com diagnóstico de síndrome de Stickler tipo I. O Caso16 (Figura 29) apresentou padrão facial com acentuada hipoplasia e retração de face média e significativa depressão da ponte nasal, que lembra os indivíduos relatados com síndrome de Marshall (OMIM 154780). Baixa estatura, observada neste caso, também é achado citado na síndrome de Marshall e não observado na síndrome de Stickler. Deficiência auditiva sensorioneural profunda bilateral estava presente nesse indivíduo. Apesar da referência de fenótipo mais grave em indivíduos com a síndrome de Marshall, na realidade existe acentuada sobreposição clínica entre essa e a síndrome de Stickler. A literatura é, ainda, controversa em relação a essas síndromes representarem condições distintas ou manifestações de uma única síndrome (Griffith et al 1998, Poulson et al 2004). Análise molecular tem mostrado tanto mutações no gene COL11A1 quanto no gene COL2A1 em indivíduos com achados clínicos das síndromes de Stickler e de Marshall (Annunen et al 1999). Indivíduos com mutação no COL11A1 apresentavam deficiência auditiva grave e raramente descolamento de retina ou degeneração do vítreo. Esses foram classificados como síndrome de Marshall ou como uma sobreposição das síndromes Marshall-Stickler. Os indivíduos que apresentavam 
mutações no COL2A1 foram considerados como tendo síndrome de Stickler. Caracterização molecular de famílias adicionais com sobreposição desses achados clínicos é necessária para esclarecer a relação genética existente entre essas síndromes. 


\subsubsection{Grupo 3: Indivíduos com deficiência auditiva e envolvimento neurológico (Casos 17 a 20)}

Nesse grupo foram incluídos 4 indivíduos com deficiência auditiva sensorioneural e comprometimento neurológico. Diagnóstico não foi conclusivo em nenhum dos casos. A Tabela 9 mostra os dados referentes a esse grupo. 
TABELA 9: Dados dos indivíduos com deficiência auditiva e envolvimento neurológico

\begin{tabular}{|c|c|c|c|c|c|c|}
\hline Indivíduo & Sexo & Idade & Sinais clínicos & $\begin{array}{l}\text { Dados gestacionais e perinatais/ } \\
\text { antecedentes pessoais e familiais }\end{array}$ & $\begin{array}{l}\text { Exames complementares e } \\
\text { caracterização da DA }\end{array}$ & $\begin{array}{l}\text { Hipótese diagnóstica } \\
\text { (modelo de herança) }\end{array}$ \\
\hline 17 & $\mathrm{~F}$ & $11 \mathrm{a} 9 \mathrm{~m}$ & $\begin{array}{l}\text { Fendas palpebrais estreitas; deficiência } \\
\text { auditiva; hérnia inguinal à } \mathrm{D} \text {; dígitos longos; } \\
\text { hiperelasticidade articular; clinodactilia ulnar } \\
\text { do } 3^{\circ} \text { dígito à E; dificuldades de } \\
\text { aprendizagem apatia; ADNPM }\end{array}$ & $\begin{array}{l}\text { IMC: } 29 \mathrm{a} / \mathrm{IPC}: 28 \mathrm{a} \quad \mathrm{G} 3 \mathrm{P} 2 \mathrm{~A} 1 \\
\text { Sangramento intenso no } 8^{\circ} \text { mês gestacional } \\
\text { (placenta prévia). } \\
\text { Parto cesáreo; gestação de } 8 \text { meses. } \\
\mathrm{PN}=2.130 \mathrm{~g}(\mathrm{p}<3) \quad \mathrm{EN}=48 \mathrm{~cm}(\mathrm{p}=25) \\
\text { Até os } 5 \text { anos de idade, teve amigdalites de } \\
\text { repetição e problemas de adenóide. } \\
\text { Caso isolado. }\end{array}$ & $\begin{array}{l}\text { Cariótipo: } 46, \mathrm{XX} \\
\text { Tomografia computadorizada de } \\
\text { crânio: normal } \\
\text { Tomografia de mastóide: normal } \\
\text { Eletroencefalograma: atividade } \\
\text { irritativa } \\
\text { Ressonância magnética de crânio: } \\
\text { normal } \\
\text { Avaliação audiológica: DA } \\
\text { sensorioneural profunda bilateral }\end{array}$ & Sem definição diagnóstica \\
\hline 18 & $\mathrm{~F}$ & $3 \mathrm{a} 8 \mathrm{~m}$ & $\begin{array}{l}\text { Microcefalia; discreta assimetria de face; } \\
\text { epicanto bilateral; hipotonia bucal; orelhas } \\
\text { proeminentes; deficiência auditiva; hélices } \\
\text { simplificados; clinodactilia do } 5^{\circ} \text { dígito } \\
\text { bilateralmente; hiperatividade, convulsões; } \\
\text { ADNPM }\end{array}$ & $\begin{array}{l}\text { IMC: } 21 \mathrm{a} / \mathrm{IPC}: 23 \mathrm{a} \quad \mathrm{G} 4 \mathrm{P} 3 \mathrm{~A} 1 \\
\text { No } 6^{\circ} \text { mês, teve pielonefrite. Internada } 1 \\
\text { dia. } \\
\text { Parto normal; gestação a termo. } \\
\mathrm{PN}=2.800 \mathrm{~g}(\mathrm{p}=10) \\
\mathrm{EN}=47 \mathrm{~cm}(3<\mathrm{p}<10) \\
\text { Convulsão febril aos } 2 \text { anos de idade. Teve } \\
\text { outros episódios convulsivos. } \\
\text { Aos } 7 \mathrm{a} 7 \mathrm{~m}: \mathrm{PC}=47 \mathrm{~cm}(\mathrm{p}<2) \\
\text { Caso isolado. }\end{array}$ & $\begin{array}{l}\text { Cariótipo: } 46, X X \\
\text { Tomografia computadorizada crânio- } \\
\text { encefálica: normal } \\
\text { Eletroencefalograma: disritmia } \\
\text { cerebral } \\
\text { Avaliação audiológica:DA } \\
\text { sensorioneural profunda bilateral }\end{array}$ & Sem definição diagnóstica \\
\hline
\end{tabular}


Continuação TABELA 9: Dados dos indivíduos com deficiência auditiva e envolvimento neurológico

\begin{tabular}{|c|c|c|c|c|c|c|}
\hline Indivíduo & Sexo & Idade & Sinais clínicos & $\begin{array}{l}\text { Dados gestacionais e perinatais/ } \\
\text { antecedentes pessoais e familiais }\end{array}$ & $\begin{array}{l}\text { Exames complementares e } \\
\text { caracterização da DA }\end{array}$ & $\begin{array}{l}\text { Hipótese diagnóstica } \\
\text { (modelo de herança) }\end{array}$ \\
\hline 19 & M & $2 \mathrm{a} 5 \mathrm{~m}$ & $\begin{array}{l}\text { Microcefalia; crânio assimétrico; nariz } \\
\text { pequeno; hipoplasia alar; micrognatia; } \\
\text { orelhas proeminentes; deficiência auditiva; } \\
\text { hipotonia; ADNPM }\end{array}$ & $\begin{array}{l}\text { IMC: } 21 \mathrm{a} / \text { IPC: } 31 \mathrm{a} \quad \text { G1P1A0 } \\
\text { Anemia no } 5^{\circ} \text { mês gestacional. } \\
\text { Parto cesáreo; gestação a termo. } \\
\text { PN= } 2.750 \mathrm{~g}(3<\mathrm{p}<10) \\
\mathrm{EN}=47 \mathrm{~cm}(\mathrm{p}=3) \\
\text { Sem intercorrências perinatais. } \\
\text { Aos 7a } 11 \mathrm{~m}: \mathrm{PC}=48 \mathrm{~cm}(\mathrm{p}<2) \\
\text { Caso isolado. }\end{array}$ & $\begin{array}{l}\text { Cariótipo: } 46, X Y \\
\text { Tomografia computadorizada crânio- } \\
\text { encefálica: normal } \\
\text { Avaliação audiológica: DA } \\
\text { sensorioneural profunda bilateral }\end{array}$ & Sem definição diagnóstica \\
\hline $20^{*}$ & M & $4 \mathrm{a} 2 \mathrm{~m}$ & $\begin{array}{l}\text { Microcefalia; epicanto bilateral; retrognatia; } \\
\text { orelhas proeminentes; deficiência auditiva; } \\
\text { hiperatividade; convulsões; ADNPM }\end{array}$ & $\begin{array}{l}\text { IMC: } 24 \mathrm{a} / \mathrm{IPC}: 35 \mathrm{a} \quad \mathrm{G} 4 \mathrm{P} 2 \mathrm{~A} 2 \\
\text { Sem intercorrências gestacionais. } \\
\mathrm{PN}=3.200 \mathrm{~g}(\mathrm{p}=25) \\
\mathrm{EN}=51 \mathrm{~cm}(\mathrm{p}=50) \\
\text { Aos } 7 \text { meses de idade, teve pneumonia. } \\
\text { Internado } 7 \text { dias. Teve crise convulsiva } \\
\text { durante internação. Não houve mudança } \\
\text { no comportamento após internação. } \\
\text { Aos 4a } 7 \mathrm{~m}: \mathrm{PC}=45.5 \mathrm{~cm}(\mathrm{p}<2) \\
\text { Caso isolado }\end{array}$ & $\begin{array}{l}\text { Cariótipo: } 46, \mathrm{XY} \\
\text { Eletroencefalograma: normal } \\
\text { Tomografia computadorizada crânio- } \\
\text { encefálica: normal } \\
\text { Avaliação audiológica: DA } \\
\text { sensorioneural severa bilateral }\end{array}$ & Sem definição diagnóstica \\
\hline
\end{tabular}



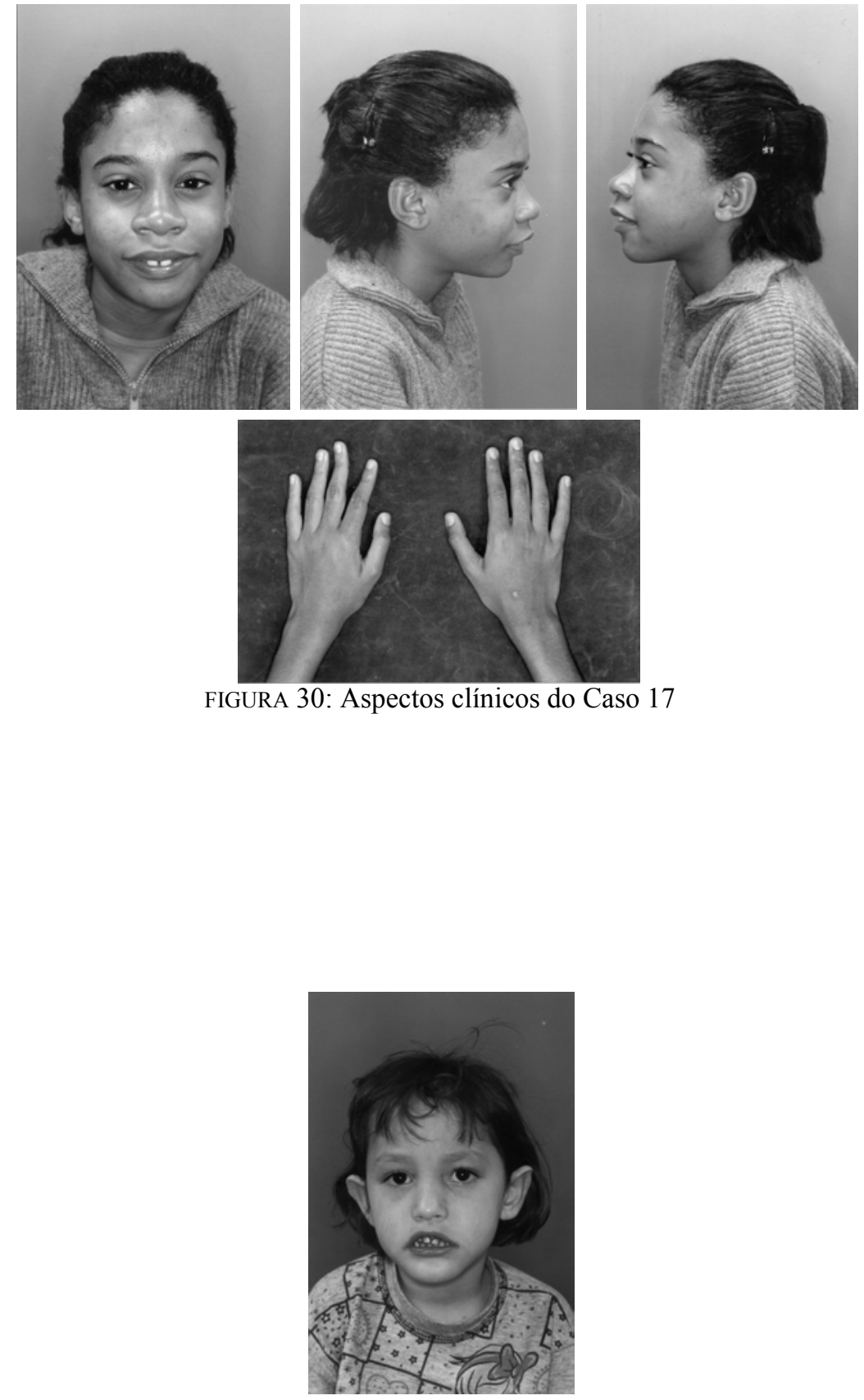

FIGURA 31: Aspectos clínicos do Caso 18 


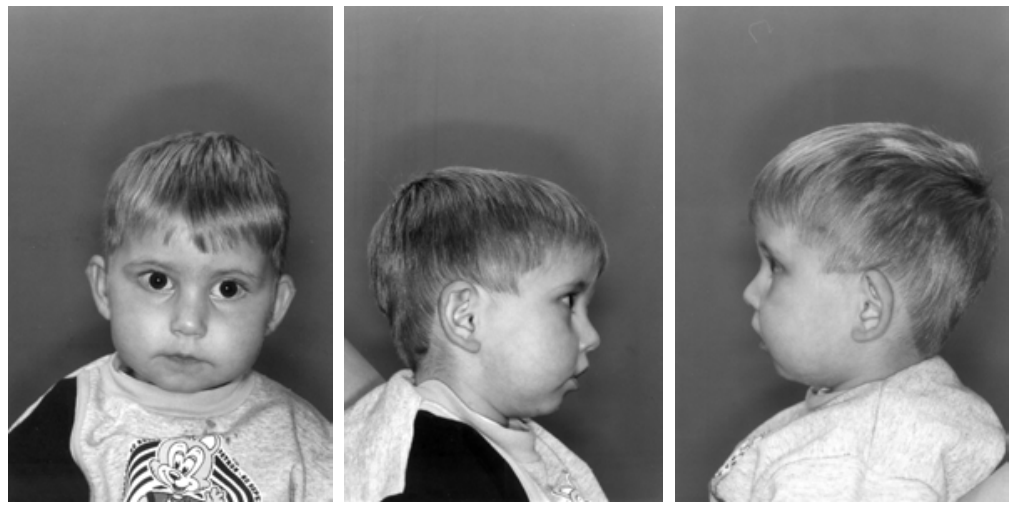

FIGURA 32: Aspectos clínicos do Caso 19

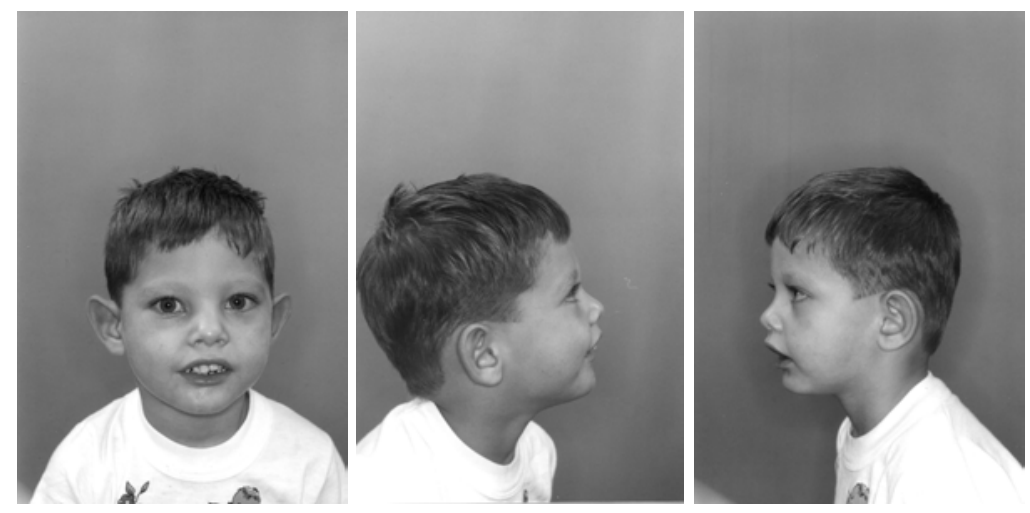

FIGURA 33: Aspectos clínicos do Caso 20 
Os indivíduos desse grupo apresentaram um conjunto de sinais clínicos que não permitiu uma definição diagnóstica (Tabela 9). Em todos os casos não há consangüinidade parental, antecedentes familiais ou ambientais que possam sugerir qualquer fator causal. Em relação ao Caso 17 (Figura 30), achados clínicos, como dificuldades de aprendizagem e distúrbio de comportamento, levaram a considerar a possibilidade de tratar-se da síndrome velocardiofacial (OMIM 192430), determinada por microdeleção na região 22 q11; porém, seu padrão facial não é característico desse quadro. Cardiopatia congênita, achado comum desta síndrome, estava ausente no Caso 17. Deficiência auditiva sensorioneural, embora menos freqüentemente, têm sido citada em indivíduos com a síndrome velocardiofacial. Embora a maioria dos casos seja esporádica, é estimado que, pelo menos $8 \%$ das deleções são herdadas de pais portadores. Microdeleções no cromossomo 22 q11.2 são detectadas em cerca de $75 \%$ dos casos pela técnica de FISH e, em 98\% dos indivíduos afetados, através da técnica da PCR. Investigação dessa natureza poderia auxiliar no esclarecimento diagnóstico do Caso 17.

Os Casos 18, 19 e 20 (Tabela 9; Figuras 31, 32 e 33, respectivamente) apresentaram sinais clínicos similares entre si, incluindo microcefalia, orelhas proeminentes, deficiência auditiva sensorioneural e atraso no desenvolvimento neuropsicomotor, além de hiperatividade, convulsões e outros sinais menores. Aparência facial similar foi observada nos indivíduos 18 e 20 . Microcefalia e deficiência auditiva sensorioneural foram sinais mandatórios na tentativa de se estabelecer um diagnóstico para estes casos e, o quadro genético que mostrou maior concordância entre os achados clínicos foi o da síndrome de Kawashima-Tsuji (síndrome da microcefalia-surdez - OMIM 156620). Esses autores, em 1987, descreveram mãe e filho com padrão característico de orelha, microcefalia, atraso mental e deficiência auditiva sensorioneural. Comparação clínica entre esses indivíduos com os Casos 18, 19 e 20 mostrou que a diferença reside no padrão de anomalias de orelhas. Enquanto esses apresentam apenas orelhas proeminentes, aqueles apresentam orelhas “em concha”. É possível que a condição descrita por Kawashima e Tsuji (1987) seja a mesma referida por Toriello et al (1985), ao relatarem uma família onde dois irmãos e um primo apresentavam o mesmo padrão de anomalias. $\mathrm{O}$ comprometimento auricular era mais leve nos afetados dessa família do que na descrita por Kawashima e Tsuji (1987) e, a deficiência auditiva era do tipo misto. Herança ligada ao $\mathrm{X}$ foi 
considerada por Toriello et al (1985). Para os Casos 18, 19 e 20, herança ligada ao X é descartada pela presença de um indivíduo do sexo feminino. O relato de novos casos similares é de extrema relevância para documentar, adequadamente, o espectro fenotípico dessa síndrome, assim como para auxílio de uma definição em relação ao diagnóstico, aos aspectos etiopatogênicos e conseqüente aconselhamento genético. 


\subsubsection{Grupo 4: Indivíduos com deficiência auditiva e envolvimento ocular (Casos 21 a 29)}

Incluiu-se, nesse grupo, 9 indivíduos com deficiência auditiva e anomalias oculares. Síndrome de Usher foi considerada como diagnóstico de 4 indivíduos (Casos 21 a 24); síndrome de Gernet em 2 (Casos 25 e 26) e síndrome FineLubinsky em outros 2 (Casos 27 e 28). Em apenas 1 indivíduo (Caso 29), não foi possível se estabelecer um diagnóstico. Deficiência auditiva sensorioneural foi observada na totalidade dos casos. Os dados referentes a esse grupo encontram-se na Tabela 10. 
TABELA 10: Dados dos indivíduos com deficiência auditiva e envolvimento ocular

\begin{tabular}{|c|c|c|c|c|c|c|}
\hline Indivíduo & Sexo & Idade & Sinais clínicos & $\begin{array}{l}\text { Dados gestacionais e perinatais/ } \\
\text { antecedentes pessoais e familiais }\end{array}$ & $\begin{array}{l}\text { Exames complementares e } \\
\text { caracterização da DA }\end{array}$ & $\begin{array}{l}\text { Hipótese diagnóstica } \\
\text { (modelo de herança) }\end{array}$ \\
\hline 21 & $\mathrm{~F}$ & $4 \mathrm{a} 2 \mathrm{~m}$ & $\begin{array}{l}\text { Retinose pigmentar, fusão do incisivo } \\
\text { inferior lateral D; deficiência auditiva; } \\
\text { hiperatividade }\end{array}$ & $\begin{array}{l}\text { IMC: } 20 \mathrm{a} \quad \text { IPC: } 23 \mathrm{a} \quad \text { G2P2A0 } \\
\text { Ameaço de aborto no } 3^{\circ} \text { mês gestacional. } \\
\text { Ameaço de parto prematuro no } 7^{\circ} \text { mês. } \\
\text { Parto cesáreo; gestação a termo. } \\
\mathrm{PN}=2.100 \mathrm{~g}(\mathrm{p}<3) \\
\mathrm{EN}=47 \mathrm{~cm}(3<\mathrm{p}<10) \\
\text { Caso isolado. }\end{array}$ & $\begin{array}{l}\text { Cariótipo: } 46, \mathrm{XX} \\
\text { Avaliação oftalmológica: retina } \\
\text { pigmentar em início em ambos os } \\
\text { olhos } \\
\text { Avaliação audiológica:DA } \\
\text { sensorioneural profunda bilateral }\end{array}$ & $\begin{array}{l}\text { Síndrome de Usher } \\
\text { tipo I } \\
\text { (HAR) }\end{array}$ \\
\hline $22 *$ & $\mathrm{~F}$ & $46 a$ & $\begin{array}{l}\text { Hipermetropia retinose pigmentar, } \\
\text { deficiência auditiva }\end{array}$ & $\begin{array}{l}\text { IMC: ? / IPC: ? G7P7A0 } \\
\text { Sem intercorrências gestacionais. } \\
\text { Parto normal; gestação a termo. } \\
\mathrm{PN}=\text { ? EN=? } \\
\text { Sem intercorrências neonatais. } \\
\text { Caso isolado. }\end{array}$ & $\begin{array}{l}\text { Cariótipo: } 46, \mathrm{XX} \\
\text { Avaliação oftalmológica: alta } \\
\text { hipermetropia e retinose pigmentar } \\
\text { Avaliação audiológica:DA } \\
\text { sensorioneural profunda bilateral }\end{array}$ & $\begin{array}{l}\text { Síndrome de Usher } \\
\text { tipo I } \\
\text { (HAR) }\end{array}$ \\
\hline $23^{*}$ & F & $13 \mathrm{a} 8 \mathrm{~m}$ & $\begin{array}{l}\text { Retinose pigmentar, deficiência auditiva; } \\
\text { ADNM }\end{array}$ & $\begin{array}{l}\text { IMC: } 28 \mathrm{a} \quad \text { IPC: } 29 \mathrm{a} \quad \mathrm{G} 2 \mathrm{P} 2 \mathrm{~A} 0 \\
\text { Sem intercorrências gestacionais. } \\
\text { Parto cesáreo; gestação a termo. } \\
\mathrm{PN}=4.060 \mathrm{~g}(90<\mathrm{p}<97) \quad \mathrm{EN}=\text { ? } \\
\text { Choro imediato. Apresentou icterícia. Fez } \\
\text { fototerapia. } \\
\text { Irmão igualmente afetado (caso } 24) \text {. }\end{array}$ & $\begin{array}{l}\text { Cariótipo: } 46, \mathrm{XX} \\
\text { Eletrorretinografia: retinose pigmentar } \\
\text { em ambos os olhos } \\
\text { Avaliação audiológica:DA } \\
\text { sensorioneural profunda bilateral }\end{array}$ & $\begin{array}{l}\text { Síndrome de Usher } \\
\text { tipo I } \\
\text { (HAR) }\end{array}$ \\
\hline $24^{*}$ & M & $17 \mathrm{a}$ & $\begin{array}{l}\text { Retinose pigmentar; deficiência auditiva; } \\
\text { leve ADNM }\end{array}$ & $\begin{array}{l}\text { IMC: } 31 \mathrm{a} \text { IPC: } 32 \mathrm{a} \quad \mathrm{G} 2 \mathrm{P} 2 \mathrm{~A} 0 \\
\text { Sem intercorrências gestacionais. } \\
\text { Parto cesáreo; gestação a termo. } \\
\mathrm{PN}=4.050 \mathrm{~g}(75<\mathrm{p}<90) \quad \mathrm{EN}=? \\
\text { Sem intercorrências neonatais. } \\
\text { Irmã igualmente afetada (caso } 23) \text {. }\end{array}$ & $\begin{array}{l}\text { Cariótipo: } 46, \mathrm{XY} \\
\text { Eletrorretinografia: retinose pigmentar } \\
\text { em ambos os olhos } \\
\text { Avaliação audiológica: DA } \\
\text { sensorioneural profunda bilateral }\end{array}$ & $\begin{array}{l}\text { Síndrome de Usher } \\
\text { tipo I } \\
\text { (HAR) }\end{array}$ \\
\hline
\end{tabular}


Continuação TABELA 10: Dados dos indivíduos com deficiência auditiva e envolvimento ocular

\begin{tabular}{|c|c|c|c|c|c|c|}
\hline Indivíduo & Sexo & Idade & Sinais clínicos & $\begin{array}{l}\text { Dados gestacionais e perinatais/ } \\
\text { antecedentes pessoais e familiais }\end{array}$ & $\begin{array}{l}\text { Exames complementares e } \\
\text { caracterização da DA }\end{array}$ & $\begin{array}{l}\text { Hipótese diagnóstica } \\
\text { (modelo de herança) }\end{array}$ \\
\hline 25 & M & $38 \mathrm{a}$ & $\begin{array}{l}\text { Baixa estatura; atrofia do nervo óptico } \\
\text { bilateral deficiência auditiva }\end{array}$ & 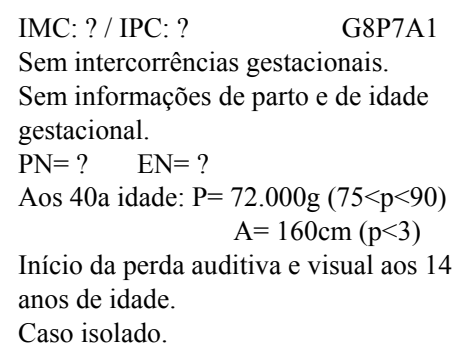 & $\begin{array}{l}\text { Cariótipo: } 46, \mathrm{XY} \\
\text { Avaliação oftalmológica: atrofia do } \\
\text { nervo óptico bilateral } \\
\text { Avaliação audiológica:DA } \\
\text { sensorioneural moderada } \\
\text { progressiva bilateral }\end{array}$ & $\begin{array}{l}\text { Sínd.rome de Gernet } \\
\text { (HAD) }\end{array}$ \\
\hline 26 & $\mathrm{~F}$ & $10 \mathrm{a} 3 \mathrm{~m}$ & $\begin{array}{l}\text { Estrabismo; atrofia do nervo óptico } \\
\text { unilateral E; orelhas proeminentes; } \\
\text { deficiência auditiva }\end{array}$ & $\begin{array}{l}\text { IMC: } 38 \mathrm{a} \quad \text { IPC: } 34 \mathrm{a} \quad \text { G3P2A1 } \\
\text { Hipotensão arterial durante a gestação. } \\
\text { Parto cesáreo; gestação a termo. } \\
\mathrm{PN}=3.800 \mathrm{~g}(75<\mathrm{p}<90) \\
\mathrm{EN}=\text { ? } \\
\text { Sem intercorrências perinatais. } \\
\text { Caso isolado. }\end{array}$ & $\begin{array}{l}\text { Cariótipo: } 46, \mathrm{XX} \\
\text { Avaliação oftalmológica: atrofia do } \\
\text { nervo óptico e corectopia unilateral E } \\
\text { Avaliação audiológica:DA } \\
\text { sensorioneural profunda bilateral }\end{array}$ & $\begin{array}{l}\text { Síndrome de Gernet } \\
\text { (HAD) }\end{array}$ \\
\hline
\end{tabular}


Continuação TABELA 10: Dados dos indivíduos com deficiência auditiva e envolvimento ocular

\begin{tabular}{|c|c|c|c|c|c|c|}
\hline Indivíduo & Sexo & Idade & Sinais clínicos & $\begin{array}{l}\text { Dados gestacionais e perinatais/ } \\
\text { antecedentes pessoais e familiais }\end{array}$ & $\begin{array}{l}\text { Exames complementares e } \\
\text { caracterização da DA }\end{array}$ & $\begin{array}{l}\text { Hipótese diagnóstica } \\
\text { (modelo de herança) }\end{array}$ \\
\hline 27 & $\mathrm{~F}$ & $12 \mathrm{a} 6 \mathrm{~m}$ & $\begin{array}{l}\text { Fendas palpebrais oblíquas para baixo; ponte } \\
\text { nasal alta; nistagmo; catarata congênita à } \\
\text { D; astigmatismo e miopia à E; discreta } \\
\text { micrognatia; orelhas com baixa implantação; } \\
\text { hélices dobrados; deficiência auditiva; } \\
\text { convulsões; hiperatividade; ADNPM }\end{array}$ & $\begin{array}{l}\mathrm{IMC}=22 \mathrm{a} / \mathrm{IPC}=23 \mathrm{a} \quad \mathrm{G} 2 \mathrm{P} 2 \mathrm{~A} 0 \\
\text { Contato com pessoa com rubéola no } 5^{\circ} \\
\text { mês gestacional. Sem conseqüências. } \\
\text { Parto normal; gestação de } 7 \text { meses. } \\
\mathrm{PN}=2.400 \mathrm{~g}(\mathrm{p}=25) \\
\mathrm{EN}=43 \mathrm{~cm}(\mathrm{p}=3) \\
\text { Sem intercorrências perinatais. } \\
\text { Caso isolado. }\end{array}$ & $\begin{array}{l}\text { Cariótipo: } 46, X X \\
\text { Avaliação oftalmológica: catarata } \\
\text { congênita à D; miopia à E (12 di) } \\
\text { Avaliação audiológica: DA } \\
\text { sensorioneural profunda bilateral }\end{array}$ & $\begin{array}{l}\text { Síndrome Fine-Lubinsky } \\
\text { (desconhecido) }\end{array}$ \\
\hline 28 & $\mathrm{~F}$ & $4 \mathrm{a} 7 \mathrm{~m}$ & $\begin{array}{l}\begin{array}{l}\text { Déficit pôndero-estatural; fronte ampla; } \\
\text { estrabismo }\end{array} \text { convergente; catarata } \\
\begin{array}{l}\text { congênita à } \\
\text { deficiência }\end{array} \text { auditiva; hicrocórnea à E; } \\
\text { ADNPM }\end{array}$ & $\begin{array}{l}\text { IMC: 16a / IPC: } 22 \mathrm{a} \quad \mathrm{G} 2 \mathrm{P} 2 \mathrm{~A} 0 \\
\text { Vários ameaços de aborto, com } \\
\text { internações. Uso de antiabortivos. Anemia } \\
\text { no } 4^{\circ} \text { mês gestacional. } \\
\text { Parto normal; gestação a termo. } \\
\mathrm{PN}=2.260 \mathrm{~g}(\mathrm{p}<3) \\
\mathrm{EN}=\text { ? } \\
\text { Sem intercorrências perinatais. } \\
\text { Caso isolado. }\end{array}$ & $\begin{array}{l}\text { Cariótipo: } 46, \mathrm{XX} \\
\text { Tomografia computadorizada crânio- } \\
\text { encefálica: normal } \\
\text { Eletroencefalograma: foco em P4-T6 } \\
\text { Avaliação oftalmológica: catarata } \\
\text { congênita à D; microcórnea à E } \\
\text { Avaliação audiológica: DA } \\
\text { sensorioneural profunda bilateral }\end{array}$ & $\begin{array}{l}\text { Síndrome Fine-Lubinsky } \\
\text { (desconhecido) }\end{array}$ \\
\hline 29 & $\mathrm{~F}$ & 2a $10 \mathrm{~m}$ & $\begin{array}{l}\text { Sutura metópica proeminente; coloboma de } \\
\text { íris bilateral; base nasal alta; hipoplasia asa } \\
\text { nasal; fissura de palato; orelhas } \\
\text { simplificadas, posteriorizadas e com baixa } \\
\text { implantação; deficiência auditiva; distúrbio } \\
\text { de comportamento; hiperatividade; ADNPM }\end{array}$ & $\begin{array}{l}\text { IMC: } 25 \mathrm{a} \quad \text { IPC: } 27 \mathrm{a} \quad \text { G2P2A0 } \\
\text { Sem intercorrências gestacionais e } \\
\text { perinatais. } \\
\text { Parto cesáreo; gestação a termo. } \\
\mathrm{PN}=3.300 \mathrm{~g}(\mathrm{p}=50) \\
\mathrm{EN}=48 \mathrm{~cm}(10<\mathrm{p}<25) \\
\text { Caso isolado. }\end{array}$ & $\begin{array}{l}\text { Cariótipo: } 46, \mathrm{XX} \\
\text { Avaliação oftalmológica: coloboma de } \\
\text { íris, retina e nervo óptico } \\
\text { bilateralmente } \\
\text { Avaliação audiológica: DA } \\
\text { sensorioneural profunda bilateral }\end{array}$ & $\begin{array}{l}\text { Síndrome de CHARGE } \\
\text { (etiologia heterogênea) }\end{array}$ \\
\hline
\end{tabular}




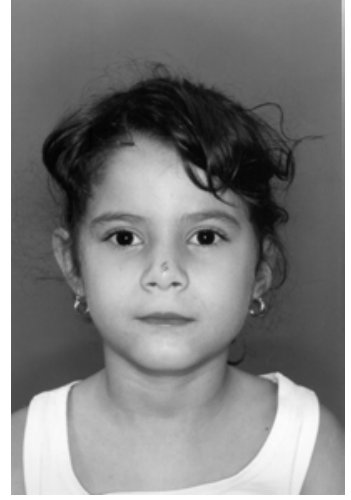

FIGURA 34: Aspectos clínicos do Caso 21

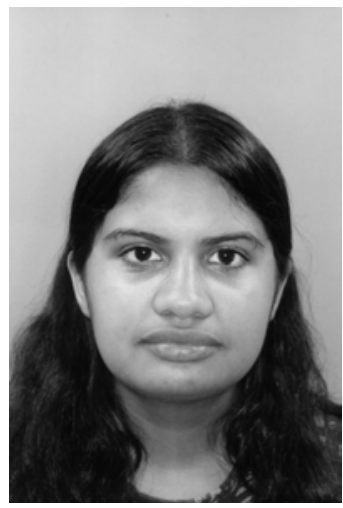

FIGURA 36: Aspectos clínicos do Caso 23

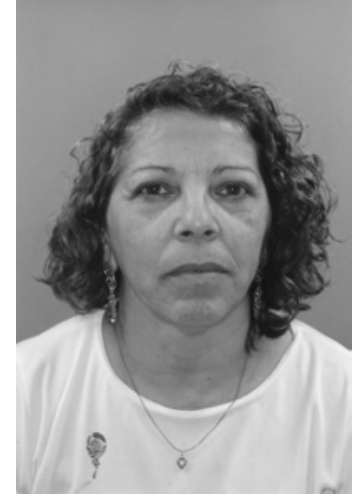

FIGURA 35: Aspectos clínicos do Caso 22

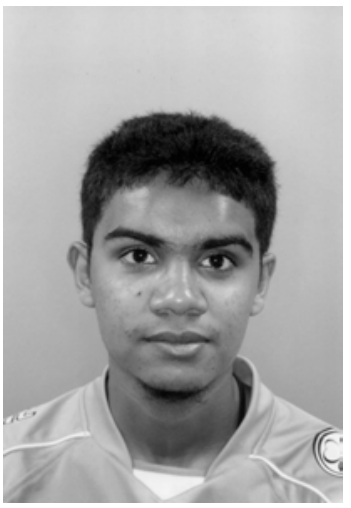

FIGURA 37: Aspectos clínicos do Caso 24

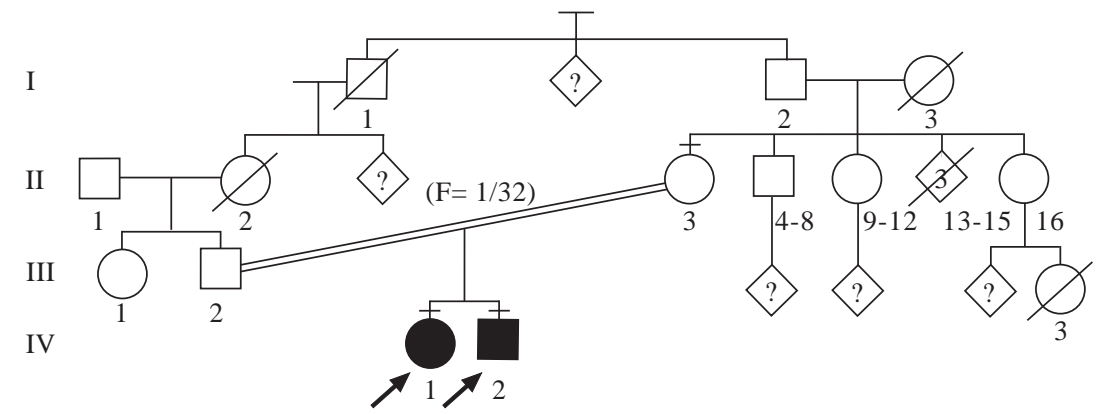

FIGURA 38: Heredograma da família dos Casos 23 e 24 


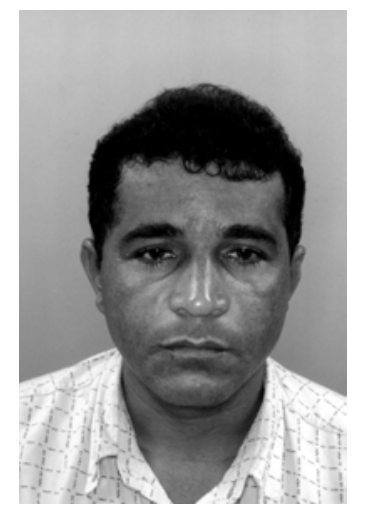

FIGURA 39: Aspectos clínicos do Caso 25
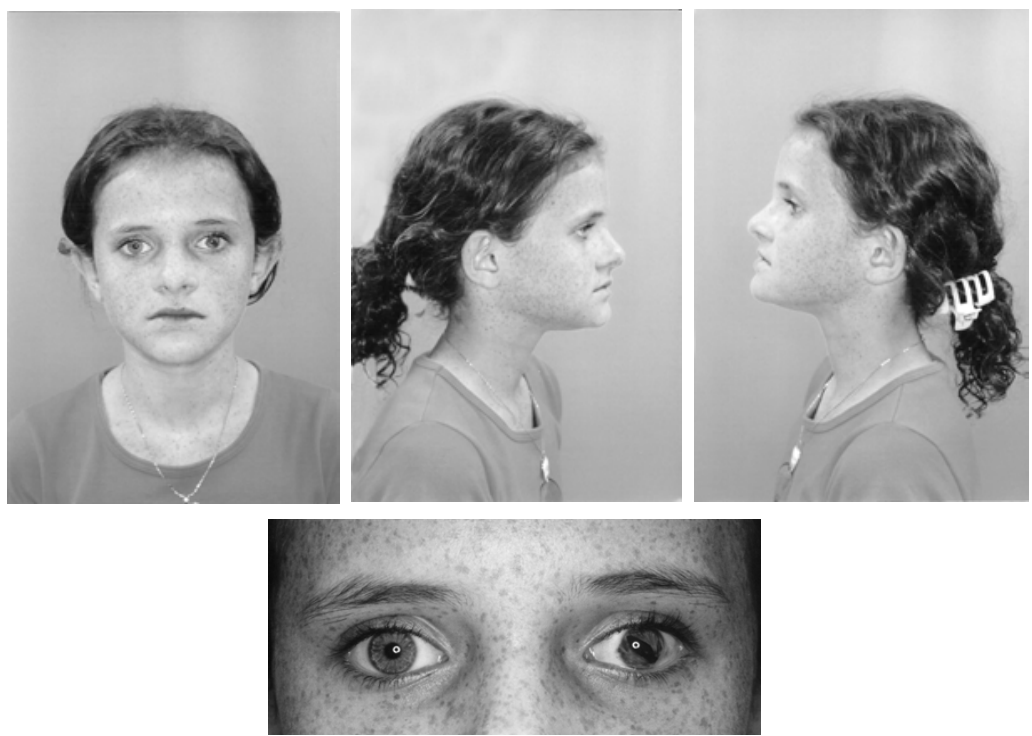

FIGURA 40: Aspectos clínicos do Caso 26 

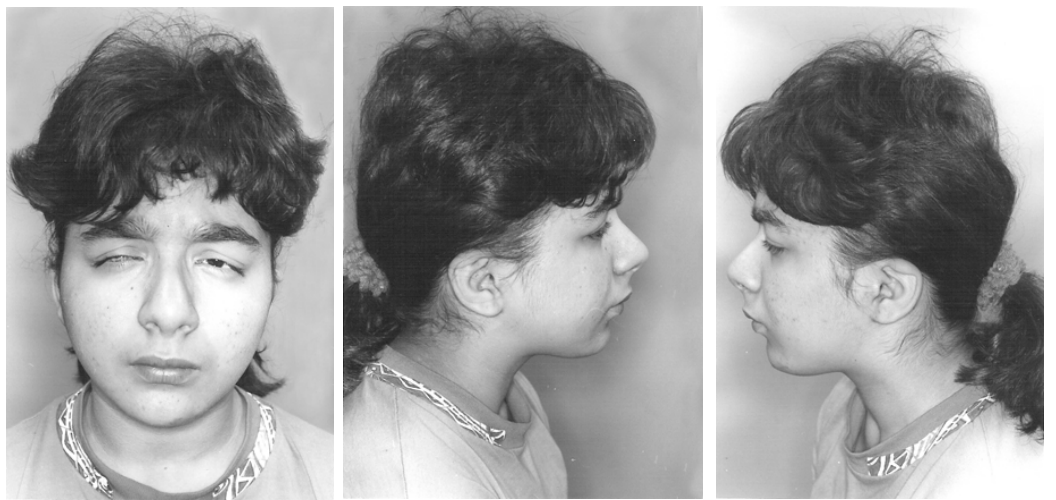

FIGURA 41: Aspectos clínicos do Caso 27
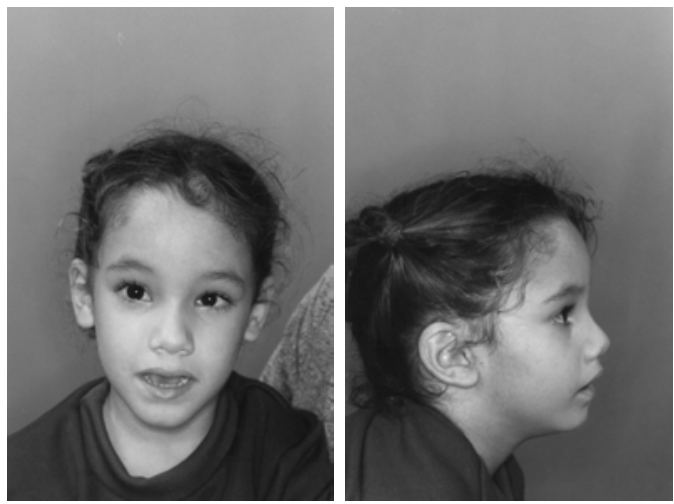

FIGURA 42: Aspectos clínicos do Caso 28
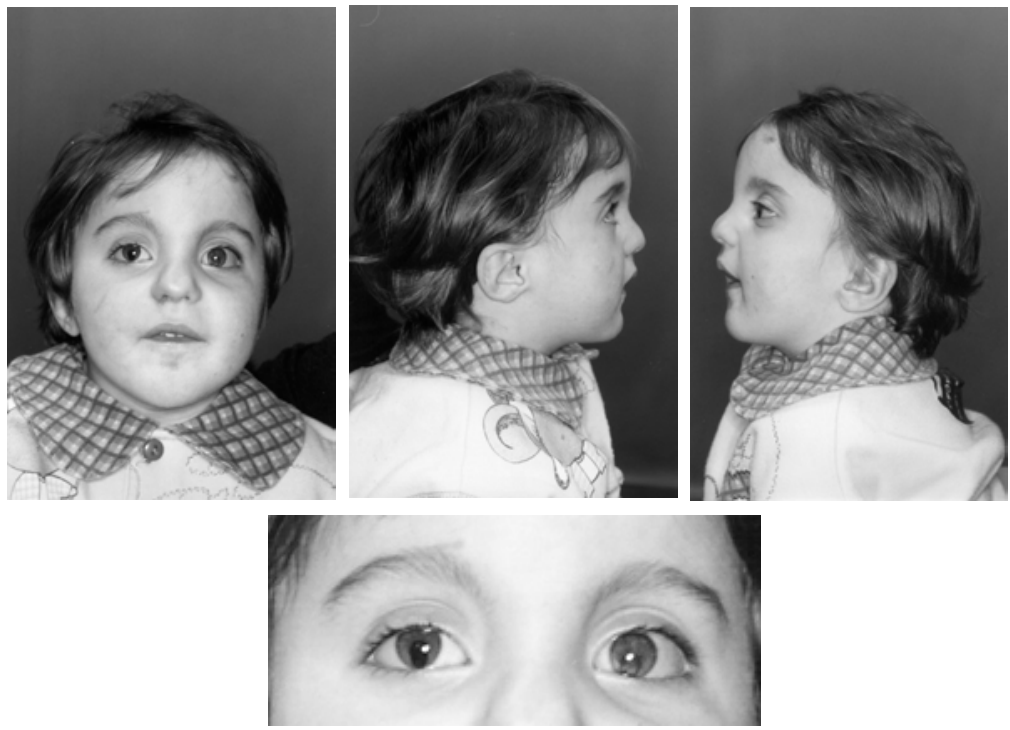

FIGURA 43: Aspectos clínicos do Caso 29 
A freqüência de anormalidades oculares encontradas entre indivíduos com deficiência auditiva é mais alta do que nos indivíduos com audição normal (Regenbogen e Godel 1985, Elango et al 1994). As malformações oculares podem ocorrer isoladas ou acompanhar outras anormalidades sistêmicas no contexto de dezenas de síndromes malformativas (LDDB, 1996; POSSUM, 1998; OMIM Junho de 2006).

O diagnóstico estabelecido para os Casos 21, 22, 23 e 24 (Tabela 10; Figuras 34, 35, 36 e 37, respectivamente), da presente casuística, foi síndrome de Usher. Essa síndrome, além de ser causa freqüente de deficiência auditiva associada à cegueira, em adultos, é, ainda, o diagnóstico estabelecido em cerca de 3 a $6 \%$ das crianças nascidas com perda auditiva. A síndrome de Usher é determinada por gene autossômico recessivo e caracterizada pela combinação de retinose pigmentar e perda auditiva sensorioneural. É clinicamente heterogênea e, segundo Davenport e Omenn (1977), considerando as características da deficiência auditiva e o início da manifestação da retinose pigmentar, quatro tipos são reconhecidos: tipo I (OMIM 276900) caracterizado por deficiência auditiva congênita profunda e retinose pigmentar precoce (geralmente evidente na primeira década de vida); tipo II (OMIM 276901) caracterizado por perda auditiva congênita estável, de moderada a severa, e retinose pigmentar com início na adolescência; tipo III (OMIM 276902) caracterizado por perda auditiva progressiva e retinose pigmentar com início na segunda década de vida; tipo IV, forma possivelmente ligada ao X. Trabalho de revisão de Ahmed et al (2003), mostrou que, pelo menos, cinco genes (USH1B, USH1C, USH1D, USH1F e USH1G), na região 14q32, estão relacionados à síndrome de Usher tipo I; que mutações identificadas na região 1q41 estão relacionadas ao tipo II e, ainda que mutações na região 3q21-q25 estão relacionadas ao tipo III. No presente estudo, os Casos 21, 22, 23 e 24 apresentaram perda auditiva sensorioneural congênita profunda e retinose pigmentar com início na primeira década de vida, achados compatíveis com o tipo I da síndrome de Usher. Fusão de incisivo lateral inferior, achado clínico do Caso 21, não está relacionado à síndrome. Consangüinidade parental e recorrência familial foram observadas nos Casos 22, 23 e 24 (Figura 38; IV-1 e IV-2), evidenciando modelo de herança autossômica recessiva. Em relação ao diagnóstico diferencial, as principais síndromes a serem consideradas são: a de Leber (OMIM 204000), que apresenta atraso de crescimento e mental e, a de retinose pigmentar inversa com surdez (OMIM 268010), que apresenta hipogenitalismo. É, ainda, citada na literatura, a síndrome de retinose pigmentar-surdez (OMIM 500004), 
decorrente de mutação no gene MTTS2 do DNA mitocondrial, que é de difícil diferenciação clínica com a síndrome de Usher.

Ainda concernente aos quadros associados às anomalias oculares, síndrome de Gernet ou síndrome da atrofia óptica 1 e surdez (OMIM 125250) foi o diagnóstico considerado para os Casos 25 e 26 (Tabela 10; Figuras 39 e 40, respectivamente). A síndrome de Gernet é uma condição autossômica dominante, com variabilidade intrafamilial e clinicamente caracterizada pela associação de deficiência auditiva sensorioneural e atrofia óptica. Deficiência auditiva congênita e, ainda, de manifestação na primeira ou segunda década de vida, tem sido observada nos indivíduos com esse quadro (Gorlin et al 1995). A atrofia óptica é progressiva e acarreta perda visual entre a primeira e a terceira décadas de vida (Gernet, 1964; Gorlin et al 1995). Mutação no gene OPAl $(R 445 H)$ tem sido relacionada a este quadro (Shimizu et al, 2003; Payne et al, 2004; Li et al, 2005). Perda visual e deficiência auditiva sensorioneural leve a severa, no Caso 25, manifestaram-se aos 14 anos de idade. Já, no Caso 26, a perda auditiva sensorioneural foi congênita e profunda e, até a última avaliação, aos 12 anos de idade, não havia sido mencionada queixa quanto à acuidade visual. Baixa estatura, observada no Caso 25 e corectopia unilateral, no Caso 26, sinais não descritos na síndrome de Gernet, podem, ou não, representar achados adicionais. Em relação ao diagnóstico diferencial, cerca de dezessete síndromes, que cursam com deficiência auditiva e atrofia óptica, são conhecidas; porém, na sua grande maioria, neuropatia é característica marcante (Gorlin et al 1995). A ausência desse achado, nos casos em questão, permite a exclusão desses quadros. Sendo a síndrome de Gernet autossômica dominante e, considerando ainda, que os Casos 25 e 26 são isolados, é possível que esses sejam decorrentes de mutação nova.

Os Casos 27 e 28 (Tabela 10; Figuras 41 e 42, respectivamente), da presente casuística, apresentaram, em comum, deficiência auditiva sensorioneural, catarata e atraso mental. Várias síndromes malformativas e metabólicas apresentam estes sinais clínicos como parte do quadro (Guala et al 1992; Gorlin et al 1995). Dentre elas, a que mostrou maior concordância com os achados clínicos dos Casos 27 e 28 foi a síndrome Fine-Lubinsky (OMIM 601353), caracterizada por braquicefalia, surdez, catarata, microstomia e atraso mental. Até o momento, apenas 5 casos, todos isolados e sem consangüinidade parental, foram descritos na literatura (Fine e Lubinsky 1983, Preus et al 1984, Suthers et al 1993, Aymé e Philip 1996, Nakane et al 2002). 
Braquicefalia é achado comum nesses indivíduos e, evidência radiológica de sinostose coronal só foi evidente em um dos quatro indivíduos submetidos a esta avaliação. A deficiência auditiva, em todos os indivíduos, era do tipo sensorioneural. Catarata não foi observada no caso relatado por Preus et al (1984) e, anomalias oculares, como megalocórnea e glaucoma, estavam presentes no indivíduo relatado por Fine e Lubinsky (1983). Embora a aparência facial dos Casos 27 e 28, da presente casuística, não seja similar a dos indivíduos descritos com a síndrome de Fine-Lubinsky, a concordância de sinais clínicos não permite a exclusão deste quadro. Dos sinais cardinais, não se observou braquicefalia no Caso 28 e microstomia, nos Casos 27 e 28 . Este último sinal clínico também não foi observado no indivíduo relatado por Nakane et al (2002). Em relação às anomalias oculares, catarata foi detectada nos Casos 27 e 28 e, ainda, miopia alta e microcórnea, manifestações clínicas não relatadas previamente, estavam presentes. Ambos os casos tiveram perda auditiva sensorioneural profunda. Considerando que a síndrome de Fine-Lubinsky é rara e que está em fase inicial de delineamento, outros achados clínicos como assimetria facial (Aymé e Philip 1996, Fine e Lubinsky 1983), assimetria corporal, atraso de crescimento e fissura de palato submucosa (Fine e Lubinsky 1983), podem, ou não, fazer parte do espectro fenotípico. Até o momento a etiologia da síndrome Fine-Lubinsky permanece desconhecida. Os Casos 27 e 28, assim como os descritos em literatura, são isolados e sem consangüinidade parental. Isso sugere ou uma mutação nova, ou herança autossômica recessiva ou microdeleção. Novos relatos da síndrome de Fine-Lubinsky poderão auxiliar no delineamento dessa condição, bem como, no esclarecimento da etiologia envolvida.

As manifestações clínicas observadas no Caso 29 (Tabela 10; Figura 43) incluem coloboma de íris, fissura de palato, anomalias menores de orelha, deficiência auditiva sensorioneural e atraso de crescimento e desenvolvimento. Embora estes achados façam parte do fenótipo de vários quadros (síndrome de CHARGE - OMIM 214800; síndrome Abruzzo-Erickson - OMIM 302905; síndrome Baraitser-Winter OMIM 243310; síndrome do coloboma-microftalmia, tipo Kingston - OMIM 120433; síndrome do olho do gato - OMIM 115470) a condição que apresenta maior concordância de achados clínicos é a síndrome de CHARGE. As letras do acrônimo CHARGE indicam as seis anomalias cardinais dessa condição (Coloboma - coloboma, Heart - defeito cardíaco, Atresia choanae - atresia de coanas, Retarded growth - atraso 
de crescimento e desenvolvimento e/ou anomalias do sistema nervoso central, Genital hypoplasia - hipoplasia genital e Ear anomalies - anomalias de orelha e/ou deficiência auditiva). Recorrência familial; gêmeos monozigóticos fenotipicamente concordantes para o quadro; gêmeos dizigóticos discordantes para o quadro; anormalidades cromossômicas variáveis; microdeleção na região 22q11.2; mutações nos genes PAX2 e CHD7 evidenciam base genética para esta condição (Emanuel et al 1992, North et al 1995, Tellier et al 1998, Lalani et al 2006, Aramaki et al 2006), inicialmente considerada como uma associação. Trabalhos de revisão mostram que, embora, os achados craniofaciais na síndrome de CHARGE sejam peculiares, altamente característicos e cruciais para o diagnóstico dessa condição, a aparência facial é variável. Manifestações como deficiência auditiva, dificuldades alimentares graves e prognóstico ruim têm se mostrado importante (Tellier et al 1998, Gorlin et al 2001). Embora o Caso 29 apresente sobreposição clínica acentuada com a síndrome de CHARGE, sua aparência facial e sua evolução não são características freqüentemente observadas nos indivíduos com esse quadro. Isso, porém, não exclui essa possibilidade diagnóstica, principalmente ao se considerar que o critério mínimo estabelecido é a presença de, pelo menos, três anomalias cardinais. Cabe comentar que existe um quadro sobreposto à síndrome de CHARGE, denominado síndrome Charge-like ou síndrome Abruzzo-Erickson (OMIM 302905), possivelmente ligado ao cromossomo X e que, por não apresentar comprometimento mental, foi excluído como diagnóstico para o Caso 29. Aparência facial típica (hipertelorismo ocular e ptose palpebral) presente na síndrome de Baraitser-Winter (OMIM 243310) e, microftalmia na síndrome do coloboma-microftalmia, tipo Kingston (OMIM 120433), diferenciam essas condições daquela referente ao Caso 29. Estudo citogenético, nesse indivíduo, descartou, ainda, a síndrome do olho do gato (OMIM 115470), decorrente de tetrassomia parcial do cromossomo 22 [inv $\operatorname{dup}(22)(\mathrm{q} 11)]$. 


\subsubsection{Grupo 5: Indivíduos com deficiência auditiva e envolvimento de orelha externa (Casos 30 a 55)}

$\mathrm{Na}$ Tabela 11, encontram-se os dados referentes aos 26 indivíduos com deficiência auditiva e anomalias de orelha externa. Síndrome da atresia aural, microtia e perda auditiva condutiva foi observada em 5 indivíduos (Casos 30 a 34); síndrome da atresia aural, microtia e perda auditiva condutiva ou espectro oculoauriculovertebral em 9 (Casos 35 a 43); espectro oculoauriculovertebral em 4 (Casos 44 a 47); síndrome de Treacher-Collins em 3 (Casos 48 a 50); síndrome de Nager em 2 (Casos 51 e 52) e síndrome branquio-oto-renal em 2 (Casos 53 e 54). No Caso 55, não foi possível se definir um diagnóstico. Nesse grupo, observou-se 21 indivíduos com deficiência auditiva condutiva, 3 com sensorioneural e 2 com perda auditiva condutiva e sensorioneural. 
TABELA 11: Dados dos indivíduos com deficiência auditiva e envolvimento de orelha externa

\begin{tabular}{|c|c|c|c|c|c|c|}
\hline Indivíduo & Sexo & Idade & Sinais clínicos & $\begin{array}{l}\text { Dados gestacionais e perinatais/ } \\
\text { antecedentes pessoais e familiais }\end{array}$ & $\begin{array}{l}\text { Exames complementares e } \\
\text { caracterização da DA }\end{array}$ & $\begin{array}{l}\text { Hipótese diagnóstica } \\
\text { (modelo de herança) }\end{array}$ \\
\hline 30 & $\mathrm{M}$ & $8 \mathrm{a} 11 \mathrm{~m}$ & $\begin{array}{l}\text { Retrognatia; microtia tipo II à } \mathrm{D} \text {; atresia } \\
\text { MAE à D; deficiência auditiva }\end{array}$ & $\begin{array}{l}\text { IMC: } 24 \mathrm{a} / \text { IPC: } 29 \mathrm{a} \quad \text { G2P2A0 } \\
\text { Pneumonia no } 4^{\circ} \text { mês gestacional. } \\
\text { Internada } 6 \text { dias. } \\
\text { Parto cesáreo; gestação a termo. } \\
\mathrm{PN}=2.950 \mathrm{~g}(10<\mathrm{p}<25) \\
\mathrm{EN}=49 \mathrm{~cm}(10<\mathrm{p}<25) \\
\text { Icterícia leve. } \\
\text { Caso isolado. }\end{array}$ & $\begin{array}{l}\text { Cariótipo: } 46, X Y \\
\text { Ultrassom renal: normal } \\
\text { Tomografia computadorizada de osso } \\
\text { temporal: normal } \\
\text { Avaliação audiológica:DA condutiva } \\
\text { moderada à D }\end{array}$ & $\begin{array}{c}\text { Síndrome da atresia aural, } \\
\text { microtia e deficiência auditiva } \\
\text { condutiva } \\
\text { (HAD/HAR) }\end{array}$ \\
\hline 31 & M & $5 \mathrm{~m}$ & $\begin{array}{l}\text { Fronte ampla; epicanto bilateral; } \\
\text { microtia tipo II à D com agenesia } \\
\text { MAE; deficiência auditiva }\end{array}$ & $\begin{array}{l}\text { IMC: } 30 \mathrm{a} / \text { IPC: } 32 \mathrm{a} \quad \text { G4P3A1 } \\
\text { Sangramento no } 1^{\circ} \text { e } 2^{\circ} \text { meses; } \\
\text { oligoidrâmnio no final. } \\
\text { Parto cesáreo; gestação de } 8 \mathrm{~m} \text {. } \\
\mathrm{PN}=2.750 \mathrm{~g}(10<\mathrm{p}<25) \\
\mathrm{EN}=47.5 \mathrm{~cm}(10<\mathrm{p}<25) \\
\text { Caso isolado. }\end{array}$ & $\begin{array}{l}\text { Cariótipo: } 46, X Y \\
\text { Avaliação audiológica: DA condutiva } \\
\text { moderada à D }\end{array}$ & $\begin{array}{c}\text { Síndrome da atresia aural, } \\
\text { microtia e deficiência auditiva } \\
\text { condutiva } \\
\text { (HAD/HAR) }\end{array}$ \\
\hline 32 & M & $3 \mathrm{a} 7 \mathrm{~m}$ & $\begin{array}{l}\text { Epicanto bilateral; discreta retrognatia; } \\
\text { microtia tipo II à D com agenesia } \\
\text { MAE; deficiência auditiva }\end{array}$ & $\begin{array}{l}\text { IMC: } 30 \mathrm{a} / \mathrm{IPC}: 35 \mathrm{a} \quad \mathrm{G} 2 \mathrm{P} 2 \mathrm{~A} 0 \\
\text { Sem intercorrências gestacionais } \\
\text { relevantes. } \\
\text { Parto cesáreo; gestação a termo. } \\
\mathrm{PN}=3.450 \mathrm{~g}(\mathrm{p}=50) \\
\mathrm{EN}=52 \mathrm{~cm}(50<\mathrm{p}<75) \\
\text { Sem intercorrências perinatais. } \\
\text { Caso isolado. }\end{array}$ & $\begin{array}{l}\text { Cariótipo: } 46, X Y \\
\text { Tomografia computadorizada osso } \\
\text { temporal: agenesia CAE e atresia da caixa } \\
\text { timpânica e cadeia ossicular à D } \\
\text { Avaliação audiológica:DA condutiva } \\
\text { moderada à D }\end{array}$ & $\begin{array}{l}\text { Síndrome da atresia aural, } \\
\text { microtia e deficiência auditiva } \\
\text { condutiva } \\
\text { (HAD/HAR) }\end{array}$ \\
\hline
\end{tabular}


Continuação TABELA 11: Dados dos indivíduos com deficiência auditiva e envolvimento de orelha externa

\begin{tabular}{|c|c|c|c|c|c|c|}
\hline Indivíduo & Sexo & Idade & Sinais clínicos & $\begin{array}{l}\text { Dados gestacionais e perinatais/ } \\
\text { antecedentes pessoais e familiais }\end{array}$ & $\begin{array}{l}\text { Exames complementares e } \\
\text { caracterização da DA }\end{array}$ & $\begin{array}{l}\text { Hipótese diagnóstica } \\
\text { (modelo de herança) }\end{array}$ \\
\hline 33 & M & $5 \mathrm{a} 11 \mathrm{~m}$ & $\begin{array}{l}\text { Microtia tipo II à D com agenesia } \\
\text { MAE; deficiência auditiva }\end{array}$ & $\begin{array}{l}\text { IMC: } 26 \mathrm{a} / \mathrm{IPC}: 32 \mathrm{a} \quad \mathrm{G} 3 \mathrm{P} 3 \mathrm{~A} 0 \\
\text { Sem intercorrências gestacionais. } \\
\text { Parto cesáreo; gestação a termo. } \\
\mathrm{PN}=3.640 \mathrm{~g}(50<\mathrm{p}<75) \\
\mathrm{EN}=50 \mathrm{~cm}(\mathrm{p}=25 \mathrm{~cm}) \\
\text { Sem intercorrências perinatais. } \\
\text { Pai com agenesia CAE à D e DA } \\
\text { condutiva. }\end{array}$ & $\begin{array}{l}\text { Cariótipo: } 46, X Y \\
\text { Tomografia computadorizada osso } \\
\text { temporal: ausência de CAE e cadeia } \\
\text { ossicular à D } \\
\text { Avaliação audiológica:DA condutiva } \\
\text { moderada à D }\end{array}$ & $\begin{array}{c}\text { Síndrome da atresia aural, } \\
\text { microtia e deficiência auditiva } \\
\text { condutiva } \\
\text { (HAD/HAR) }\end{array}$ \\
\hline 34 & M & 9a 9m & $\begin{array}{l}\text { Microtia tipo I à D com atresia MAE; } \\
\text { deficiência auditiva leve ADNM }\end{array}$ & $\begin{array}{l}\text { IMC: } 19 \mathrm{a} / \mathrm{IPC}: 21 \mathrm{a} \quad \mathrm{G} 1 \mathrm{P} 1 \mathrm{~A} 0 \\
\text { Sem intercorrências gestacionais } \\
\text { relevantes. } \\
\text { Parto cesáreo; gestação a termo. } \\
\mathrm{PN}=2.600 \mathrm{~g}(\mathrm{p}=3) \\
\mathrm{EN}=46 \mathrm{~cm}(\mathrm{p}<3) \\
\text { Sem intercorrências perinatais. } \\
\text { Caso isolado. }\end{array}$ & $\begin{array}{l}\text { Cariótipo: } 46, X Y \\
\text { Avaliação audiológica:DA condutiva } \\
\text { moderada à D }\end{array}$ & $\begin{array}{c}\text { Síndrome da atresia aural, } \\
\text { microtia e deficiência auditiva } \\
\text { condutiva } \\
\text { (HAD/HAR) }\end{array}$ \\
\hline
\end{tabular}


Continuação TABELA 11: Dados dos indivíduos com deficiência auditiva e envolvimento de orelha externa

\begin{tabular}{|c|c|c|c|c|c|}
\hline Indivíduo & Sexo & Idade & Sinais clínicos & $\begin{array}{l}\text { Dados gestacionais e perinatais/ } \\
\text { antecedentes pessoais e familiais }\end{array}$ & $\begin{array}{l}\text { Exames complementares e } \\
\text { caracterização da DA }\end{array}$ \\
\hline 35 & $\mathrm{~F}$ & $2 \mathrm{~m}$ & $\begin{array}{l}\text { Fronte ampla; discreta assimetria facial; } \\
\text { nariz pequeno; narinas antevertidas; filtro } \\
\text { longo e hipoplásico; micrognatia; } \\
\text { microtia tipo II bilateral com agenesia } \\
\text { MAE; apêndice pré-auricular à E; } \\
\text { deficiência auditiva hérnia umbilical }\end{array}$ & $\begin{array}{l}\text { IMC: } 26 \mathrm{a} / \mathrm{IPC}: 27 \mathrm{a} \quad \mathrm{G} 3 \mathrm{P} 3 \mathrm{~A} 0 \\
\text { Ameaços de aborto no } 1^{\circ} \text { e } 4^{\circ} \text { meses } \\
\text { gestacionais e ameaço de parto prematuro } \\
\text { no } 7^{\circ} \text { mês. } \\
\text { Parto cesáreo; gestação de } 8 \text { meses. } \\
\mathrm{PN}=2.400 \mathrm{~g}(3<\mathrm{p}<10) \\
\mathrm{EN}=44 \mathrm{~cm}(\mathrm{p}<3) \\
\text { Permaneceu em incubadora por } 5 \text { dias. } \\
\text { Caso isolado. }\end{array}$ & $\begin{array}{l}\text { Cariótipo: } 46, \mathrm{XX}, 9 \mathrm{ph}+ \\
\text { Tomografia computadorizada osso } \\
\text { temporal: interpretar } \\
\text { Avaliação audiológica:DA condutiva } \\
\text { moderada bilateral }\end{array}$ \\
\hline 36 & M & $4 \mathrm{a} 9 \mathrm{~m}$ & $\begin{array}{l}\text { Assimetria facial; fronte proeminente; } \\
\text { sinofre; lacrimejamento à } \mathrm{E} \text { durante o ato } \\
\text { de alimentar-se; base nasal alta; filtro } \\
\text { hipoplásico; micrognatia; agenesia } \\
\text { incisivos laterais superiores; microtia } \\
\text { tipo III à E; agenesia MAE à E; } \\
\text { deficiência auditiva }\end{array}$ & $\begin{array}{l}\text { IMC: } 29 \mathrm{a} / \text { IPC: } 28 \mathrm{a} \quad \text { G3P1A2 } \\
\text { Descolamento da placenta aos } 3 \text { meses de } \\
\text { gestação. } \\
\text { Parto cesáreo (pré-eclâmpsia); gestação a } \\
\text { termo. } \\
\mathrm{PN}=3.850 \mathrm{~g}(\mathrm{p}=75) \\
\mathrm{EN}=52 \mathrm{~cm}(50<\mathrm{p}<75) \\
\text { Sem intercorrências perinatais. } \\
\text { Caso isolado. }\end{array}$ & $\begin{array}{l}\text { Cariótipo: } 46, X Y \\
\text { Avaliação audiológica:DA condutiva } \\
\text { moderada à E }\end{array}$ \\
\hline 37 & M & 4a $1 \mathrm{~m}$ & $\begin{array}{l}\text { Assimetria facial; paralisia hemifacial } \mathrm{D} \text {; } \\
\text { obstrução do canal lacrimal à } \mathrm{D} \text {; discreta } \\
\text { micrognatia; microtia tipo III à D e tipo } \\
\text { II à } \mathbf{E} \text { com agenesia MAE; deficiência } \\
\text { auditiva; braqui-clinodactilia do } 5^{\circ} \text { dígito } \\
\text { bilateral }\end{array}$ & $\begin{array}{l}\text { IMC: } 25 \mathrm{a} / \text { IPC: } 28 \mathrm{a} \quad \text { G3P2A1 } \\
\text { Sem intercorrências gestacionais. } \\
\text { Parto normal; gestação a termo. } \\
\mathrm{PN}=3.620 \mathrm{~g}(50<\mathrm{p}<75) \\
\mathrm{EN}=49 \mathrm{~cm}(10<\mathrm{p}<25) \\
\text { Sem intercorrências perinatais. } \\
\text { Pai com microtia tipo II à E com agenesia } \\
\text { do MAE (correção cirúrgica). }\end{array}$ & $\begin{array}{l}\text { Cariótipo: } 46, \mathrm{XY} \\
\text { Tomografia computadorizada } \\
\text { osso temporal: } \\
\text { Avaliação audiológica:DA condutiva } \\
\text { moderada bilateral }\end{array}$ \\
\hline
\end{tabular}

Hipótese diagnóstica (modelo de herança)

Síndrome da atresia aural, microtia e deficiência auditiva condutiva? (HAD/HAR)

Espectro oculoauriculovertebral

(etiologia heterogênea)

Síndrome da atresia aural, microtia e deficiência auditiva condutiva?

(HAD/HAR)

Espectro oculoauriculovertebral ?

(etiologia heterogênea)

Síndrome da atresia aural, microtia e deficiência auditiva

$$
\text { condutiva? }
$$

$$
\text { (HAD/HAR) }
$$

Espectro oculoauriculovertebral ?

(etiologia heterogênea) 
Continuação TABELA 11: Dados dos indivíduos com deficiência auditiva e envolvimento de orelha externa

\begin{tabular}{|c|c|c|c|c|c|c|}
\hline Indivíduo & Sexo & Idade & Sinais clínicos & $\begin{array}{l}\text { Dados gestacionais e perinatais/ } \\
\text { antecedentes pessoais e familiais }\end{array}$ & $\begin{array}{l}\text { Exames complementares e } \\
\text { caracterização da DA }\end{array}$ & $\begin{array}{l}\text { Hipótese diagnóstica } \\
\text { (modelo de herança) }\end{array}$ \\
\hline 38 & M & $11 \mathrm{~m}$ & $\begin{array}{l}\text { Assimetria facial; hipoplasia do ramo } \\
\text { mandibularà E; desvio da rima bucal para } \\
\text { a E; microtia tipo III à E; agenesia } \\
\text { MAE à E; deficiência auditiva }\end{array}$ & $\begin{array}{l}\text { IMC: } 33 \mathrm{a} / \text { IPC: } 32 \mathrm{a} \quad \text { G2P1A1 } \\
\text { Sem intercorrências gestacionais. } \\
\text { Parto cesáreo; gestação a termo. } \\
\mathrm{PN}=3.240 \mathrm{~g}(25<\mathrm{p}<50) \\
\mathrm{EN}=49.5 \mathrm{~cm}(10<\mathrm{p}<25) \\
\text { Sem intercorrências perinatais. } \\
\text { Pai e avô paterno com apêndices pré- } \\
\text { auriculares; pai com mecha branca de } \\
\text { cabelos na região frontal. }\end{array}$ & $\begin{array}{l}\text { Cariótipo: } 46, X Y \\
\text { Tomografia computadorizada de osso } \\
\text { temporal: malformação de orelha externa } \\
\text { (agenesia CAE) e orelha média } \\
\text { associados à E } \\
\text { Avaliação audiológica:DA condutiva à } \\
\text { E }\end{array}$ & $\begin{array}{c}\text { Síndrome da atresia aural, } \\
\text { microtia e deficiência auditiva } \\
\text { condutiva? } \\
\text { (HAD/HAR) } \\
\text { Espectro } \\
\text { oculoauriculovertebral ? } \\
\text { (etiologia heterogênea) }\end{array}$ \\
\hline 39 & M & 1a $9 \mathrm{~m}$ & $\begin{array}{l}\text { Assimetria facial; hipoplasia malar; fissura } \\
\text { de palato; glossoptose; micrognatia; } \\
\text { microtia tipo III bilateral agenesia do } \\
\text { MAE bilateral deficiência auditiva }\end{array}$ & $\begin{array}{l}\text { IMC: } 26 \mathrm{a} / \text { IPC: } 53 \mathrm{a} \\
\text { Ameaço de aborto no } 3^{\circ} \text { mês gestacional. } \\
\text { Uso de antiabortivos. } \\
\text { Parto cesáreo; gestação a termo. } \\
\text { PN= } 2.875 \mathrm{~g}(\mathrm{p}=10) \\
\text { EN }=51 \mathrm{~cm}(\mathrm{p}=50) \\
\text { Permaneceu } 10 \text { dias na UTI. } \\
\text { Caso isolado. }\end{array}$ & $\begin{array}{l}\text { Cariótipo: } 46, \mathrm{XY} \\
\text { RX coluna cervical: normal } \\
\text { Tomografia computadorizada osso } \\
\text { temporal: microtia associada a um mal } \\
\text { desenvolvimento das mastóides, com } \\
\text { agenesia do CAE à D e atresia à E; } \\
\text { displasia do côndilo mandibular D } \\
\text { Avaliação audiológica:DA condutiva } \\
\text { moderada bilateral }\end{array}$ & $\begin{array}{c}\text { Síndrome da atresia aural, } \\
\text { microtia e deficiência auditiva } \\
\text { condutiva? } \\
\text { (HAD/HAR) } \\
\text { Espectro } \\
\text { oculoauriculovertebral? } \\
\text { (etiologia heterogênea) }\end{array}$ \\
\hline 40 & M & 1a $10 \mathrm{~m}$ & $\begin{array}{l}\text { Assimetria facial; hipoplasia do ramo } \\
\text { mandibular unilateral E; hipertelorismo } \\
\text { ocular; epicanto bilateral; micrognatia; } \\
\text { microtia tipo III à E; agenesia do MAE } \\
\text { à E; deficiência auditiva }\end{array}$ & $\begin{array}{l}\text { IMC: } 28 \mathrm{a} / \mathrm{IPC}: 29 \mathrm{a} \quad \text { G2P2A0 } \\
\text { Sem intercorrências gestacionais. } \\
\text { Parto normal; gestação a termo. } \\
\mathrm{PN}=3.200 \mathrm{~g}(\mathrm{p}=25) \\
\mathrm{EN}=50 \mathrm{~cm}(25<\mathrm{p}<50) \\
\text { Sem intercorrências perinatais. } \\
\text { Caso isolado. }\end{array}$ & $\begin{array}{l}\text { Cariótipo: } 46, \mathrm{XY} \\
\text { Avaliação audiológica:DA condutiva } \\
\text { moderada à } \mathbf{E}\end{array}$ & $\begin{array}{c}\text { Síndrome da atresia aural, } \\
\text { microtia e deficiência auditiva } \\
\text { condutiva? } \\
\text { (HAD/HAR) } \\
\text { Espectro } \\
\text { oculoauriculovertebral? } \\
\text { (etiologia heterogênea) }\end{array}$ \\
\hline
\end{tabular}


Continuação TABELA 11: Dados dos indivíduos com deficiência auditiva e envolvimento de orelha externa

\begin{tabular}{|c|c|c|c|c|c|c|}
\hline Indivíduo & Sexo & Idade & Sinais clínicos & $\begin{array}{l}\text { Dados gestacionais e perinatais/ } \\
\text { antecedentes pessoais e familiais }\end{array}$ & $\begin{array}{l}\text { Exames complementares e } \\
\text { caracterização da DA }\end{array}$ & $\begin{array}{l}\text { Hipótese diagnóstica } \\
\text { (modelo de herança) }\end{array}$ \\
\hline 41 & M & 4a $5 \mathrm{~m}$ & $\begin{array}{l}\text { Discreta assimetria facial; epicanto } \\
\text { bilateral; microtia tipo II bilateral com } \\
\text { agenesia MAE; apêndice pré-auricular } \\
\text { bilateral; deficiência auditiva }\end{array}$ & $\begin{array}{l}\text { IMC: } 17 \mathrm{a} / \text { IPC: } 21 \mathrm{a} \quad \text { G5P5A0 } \\
\text { Mãe tabagista }(20 \text { cigarros/dia). } \\
\text { Parto normal; gestação a termo. } \\
\mathrm{PN}=3.000 \mathrm{~g}(10<\mathrm{p}<25) \\
\mathrm{EN}=\text { ? } \\
\text { Sem intercorrências perinatais. } \\
\text { Caso isolado. }\end{array}$ & $\begin{array}{l}\text { Cariótipo: } 46, \mathrm{XY}, 16 \mathrm{qh}+ \\
\text { Avaliação audiológica:DA condutiva } \\
\text { moderada bilateral }\end{array}$ & $\begin{array}{c}\text { Síndrome da atresia aural, } \\
\text { microtia e deficiência auditiva } \\
\text { condutiva? } \\
\text { (HAD/HAR) } \\
\text { Espectro } \\
\text { oculoauriculovertebral? } \\
\text { (etiologia heterogênea) }\end{array}$ \\
\hline 42 & M & 1a $8 \mathrm{~m}$ & $\begin{array}{l}\text { Discreta assimetria facial; epicanto } \\
\text { bilateral; micrognatia; microtia tipo II } \\
\text { bilateral com agenesia MAE; apêndice } \\
\text { pré-auricular à } D \text { deficiência auditiva }\end{array}$ & $\begin{array}{l}\text { IMC: } 37 \mathrm{a} / \text { IPC: } 38 \mathrm{a} \quad \text { G4P3A1 } \\
\text { No } 1^{\circ} \text { mês gestacional foi diagnosticado } \\
\text { glomérulo nefrite auto-imune (biópsia } \\
\text { renal com anestesia local). Uso de Renitec } \\
\text { por } 4 \text { dias. } \\
\text { Parto cesáreo; gestação a termo. } \\
\mathrm{PN}=3.200 \mathrm{~g}(\mathrm{p}=25) \\
\mathrm{EN}=50 \mathrm{~cm}(25<\mathrm{p}<50) \\
\text { Sem intercorrências perinatais. } \\
1 \text { prima paterna, em } 2^{\circ} \text { grau, com } \\
\text { anomalia de orelha (não especificada). }\end{array}$ & $\begin{array}{l}\text { Cariótipo: } 46, \mathrm{XY} \\
\text { Avaliação audiológica:DA } \\
\text { condutiva moderada bilateral }\end{array}$ & $\begin{array}{c}\text { Síndrome da atresia aural, } \\
\text { microtia e deficiência auditiva } \\
\text { condutiva? } \\
\text { (HAD/HAR) } \\
\text { Espectro } \\
\text { oculoauriculovertebral? } \\
\text { (etiologia heterogênea) }\end{array}$ \\
\hline 43 & $\mathrm{~F}$ & $8 \mathrm{a} 10 \mathrm{~m}$ & $\begin{array}{l}\text { Assimetriafacial; paralisia hemifacialà } \mathrm{D} \text {; } \\
\text { macrostomia; microtia tipo I à E; } \\
\text { microtia tipo II à D; agenesia MAE } \\
\text { bilateral; apêndice pré-auricular à } D \text {; } \\
\text { deficiência auditiva; pé torto congênito } \\
\text { bilateral }\end{array}$ & $\begin{array}{l}\text { IMC: } 22 \mathrm{a} / \mathrm{IPC}: 24 \mathrm{a} \quad \text { G3P3A0 } \\
\text { Ameaço de aborto no } 3^{\circ} \text { mês gestacional. } \\
\text { Parto cesáreo; gestação a termo. } \\
\mathrm{PN}=2.700 \mathrm{~g}(3<\mathrm{p}<10) \\
\mathrm{EN}=46 \mathrm{~cm}(\mathrm{p}=3) \\
\mathrm{Sem} \text { intercorrências perinatais. } \\
1 \text { tio e } 1 \text { tia materna com malformação } \\
\text { auricular unilateral; } 1 \text { primo e } 2 \text { primas } \\
\text { maternas com apêndices pré-auriculares }\end{array}$ & $\begin{array}{l}\text { Cariótipo: } 46, \mathrm{XX} \\
\text { Tomografia computadorizada de osso } \\
\text { temporal: ausência de cadeia ossicular } \\
\text { e } \\
\text { de CAE à D; ausência de CAE à E } \\
\text { Avaliação audiológica:DA } \\
\text { condutiva moderada bilateral }\end{array}$ & $\begin{array}{c}\text { Síndrome da atresia aural, } \\
\text { microtia e deficiência auditiva } \\
\text { condutiva? } \\
\text { (HAD/HAR) } \\
\text { Espectro } \\
\text { oculoauriculovertebral? } \\
\text { (etiologia heterogênea) }\end{array}$ \\
\hline
\end{tabular}


Continuação TABELA 11: Dados dos indivíduos com deficiência auditiva e envolvimento de orelha externa

\begin{tabular}{|c|c|c|c|c|c|c|}
\hline Indivíduo & Sexo & Idade & Sinais clínicos & $\begin{array}{l}\text { Dados gestacionais e perinatais/ } \\
\text { antecedentes pessoais e familiais }\end{array}$ & $\begin{array}{l}\text { Exames complementares e } \\
\text { caracterização da DA }\end{array}$ & $\begin{array}{l}\text { Hipótese diagnóstica } \\
\text { (modelo de herança) }\end{array}$ \\
\hline 44 & M & $5 \mathrm{a} 5 \mathrm{~m}$ & $\begin{array}{l}\text { Discreta assimetria facial; paralisia } \\
\text { hemifacial D; hipoplasia malar; } \\
\text { hipermetropia bilateralmicrotia tipo II à } \\
\text { D; deficiência auditiva; cardiopatia } \\
\text { congênita; ADNM }\end{array}$ & $\begin{array}{l}\text { IMC: } 24 \mathrm{a} / \text { IPC: } 24 \mathrm{a} \\
\text { Ameaço de aborto no } 2^{\circ} \text { mês gestacional. } \\
\text { No } 7^{\circ} \text { e } 8^{\circ} \text { mês, teve ameaço de parto } \\
\text { prematuro. } \\
\text { Parto normal; gestação a termo. } \\
\mathrm{PN}=2.630 \mathrm{~g}(3<\mathrm{p}<10) \\
\mathrm{EN}=44 \mathrm{~cm}(\mathrm{p}<3) \\
\text { Choro demorado. Permaneceu } 12 \text { horas } \\
\text { na incubadora. } \\
\text { Aos } 7 \text { meses e } 21 \text { dias, realizou cirurgia } \\
\text { cardíaca. } \\
\text { Caso isolado. }\end{array}$ & $\begin{array}{l}\text { Cariótipo: 46,XY } \\
\text { Ressonância magnética de crânio: normal } \\
\text { Ecocardiograma: CIA } \\
\text { Ecografia renal: normal } \\
\text { Avaliação oftalmológica: hipermetropia } \\
\text { (3.5di à D e 1.0di à E) } \\
\text { Tomografia computadorizada de osso } \\
\text { temporal: microtia à D; sinais de } \\
\text { otomastoidite crônica possivelmente } \\
\text { reagudizada à D } \\
\text { Otoscopia: estenose CAE bilateral } \\
\text { Avaliação audiológicaDA } \\
\text { sensorioneural profunda à D e } \\
\text { moderada à E }\end{array}$ & $\begin{array}{l}\text { Espectro oculoauriculovertebral } \\
\text { (etiologia heterogênea) }\end{array}$ \\
\hline
\end{tabular}


Continuação TABELA 11: Dados dos indivíduos com deficiência auditiva e envolvimento de orelha externa

\begin{tabular}{|c|c|c|c|c|c|c|}
\hline Indivíduo & Sexo & Idade & Sinais clínicos & $\begin{array}{l}\text { Dados gestacionais e perinatais/ } \\
\text { antecedentes pessoais e familiais }\end{array}$ & $\begin{array}{l}\text { Exames complementares e } \\
\text { caracterização da DA }\end{array}$ & $\begin{array}{l}\text { Hipótese diagnóstica } \\
\text { (modelo de herança) }\end{array}$ \\
\hline 45 & M & $2 \mathrm{a} 8 \mathrm{~m}$ & $\begin{array}{l}\text { Assimetria facial; sinofre; epicanto } \\
\text { bilateral; microftalmiaà D; hipoplasia da } \\
\text { asa nasal D; desvio da rima bucal para a } \\
\text { D; micrognatia; microtia tipo III à D; } \\
\text { apêndices pré-auricularares à D } \\
\text { deficiência auditiva hérnia de hiato; } \\
\text { cardiopatia congênita; agenesia do } \\
\text { pulmão D; convulsão }\end{array}$ & $\begin{array}{l}\text { IMC: } 27 \mathrm{a} / \mathrm{IPC}: 25 \mathrm{a} \quad \text { G1P1A0 } \\
\text { Infecção urinária no } 4^{\circ} \text { mês gestacional. } \\
\text { Parto cesáreo; gestação a termo. } \\
\mathrm{PN}=3.360 \mathrm{~g}(25<\mathrm{p}<50) \\
\mathrm{EN}=49 \mathrm{~cm}(10<\mathrm{p}<25) \\
\text { Aos } 48 \text { dias de vida, apresentou um } \\
\text { episódio convulsivo, devido } \\
\text { hipoglicemia. Uso de Gardenal por } 6 \\
\text { meses. Prótese ocular à D, aos } 3 \mathrm{a} 8 \mathrm{~m} \text {. } \\
\text { Caso isolado. }\end{array}$ & $\begin{array}{l}\text { Cariótipo: 46,XY } \\
\text { Ecocardiograma: CIA } \\
\text { Tomografia computadorizada } \\
\text { crânio-encefálica: normal } \\
\text { RX tórax: agenesia pulmão D } \\
\text { Avaliação audiológicaDA } \\
\text { sensorioneural moderada à D }\end{array}$ & $\begin{array}{l}\text { Espectro oculoauriculovertebral } \\
\text { (etiologia heterogênea) }\end{array}$ \\
\hline 46 & M & $7 \mathrm{a} 11 \mathrm{~m}$ & $\begin{array}{l}\text { Hipoplasia arco zigomático; fendas } \\
\text { palpebrais estreitas; coloboma de } \\
\text { pálpebra superiorà E; dermóide epibulbar } \\
\text { à E; micrognatia acentuada; maloclusão } \\
\text { dentária; microtia tipo III bilateral ; } \\
\text { agenesia MAE bilateral apêndicespré- } \\
\text { auriculares à D; deficiência auditiva } \\
\text { apêndice cutâneo em face à D (retirado } \\
\text { cirurgicamente); anomalia coluna cervical }\end{array}$ & $\begin{array}{l}\text { IMC:15a / IPC: } 24 \mathrm{a} \quad \text { G2P2A0 } \\
\text { Dores abdominais durante todo o período } \\
\text { gestacional. } \\
\text { Parto cesáreo; gestação a termo. } \\
\mathrm{PN}=3.500 \mathrm{~g}(\mathrm{p}=50) \\
\mathrm{EN}=45 \mathrm{~cm}(\mathrm{p}<3) \\
\text { Sem intercorrências perinatais. } \\
\text { Irmã com síndrome de Silver-Russel. } \\
\text { Caso isolado. }\end{array}$ & $\begin{array}{l}\text { Cariótipo: } 46, X Y \\
\text { Tomografia computadorizada } \\
\text { crânio-encefálica: } \\
\text { Avaliação audiológicaDA condutiva } \\
\text { moderada bilateral }\end{array}$ & $\begin{array}{l}\text { Espectro oculoauriculovertebral } \\
\text { (etiologia heterogênea) }\end{array}$ \\
\hline
\end{tabular}


Continuação TABELA 11: Dados dos indivíduos com deficiência auditiva e envolvimento de orelha externa

\begin{tabular}{|c|c|c|c|c|c|c|}
\hline Indivíduo & Sexo & Idade & Sinais clínicos & $\begin{array}{l}\text { Dados gestacionais e perinatais/ } \\
\text { antecedentes pessoais e familiais }\end{array}$ & $\begin{array}{l}\text { Exames complementares e } \\
\text { caracterização da DA }\end{array}$ & $\begin{array}{l}\text { Hipótese diagnóstica } \\
\text { (modelo de herança) }\end{array}$ \\
\hline 47 & F & $11 \mathrm{~m}$ & $\begin{array}{l}\text { Déficit pôndero-estatural; assimetria } \\
\text { facial; paralisia facial à E; dermóide } \\
\text { epibulbar olho D; microtia tipo I à D; } \\
\text { apêndice pré-auricular à D (retirado } \\
\text { cirurgicamente); microtia tipo III à E; } \\
\text { deficiência auditiva; agenesia do pulmão } \\
\text { E; anomalia de coluna vertebral; ADNPM }\end{array}$ & $\begin{array}{l}\text { IMC: } 29 \mathrm{a} / \mathrm{IPC}: 31 \mathrm{a} \quad \text { G1P1A0 } \\
\text { Sem intercorrências gestacionais. } \\
\text { Parto normal; gestação de } 8 \text { meses. } \\
\mathrm{PN}=2.500 \mathrm{~g}(\mathrm{p}=3) \\
\mathrm{EN}=44 \mathrm{~cm}(\mathrm{p}<3) \\
\text { Nasceu com dificuldades respiratórias. } \\
\text { Internada } 22 \text { dias. } \\
2 \text { primas maternas, em } 3^{\circ} \text { grau, com } \\
\text { apêndice pré-auricular unilateral. }\end{array}$ & $\begin{array}{l}\text { Cariótipo: } 46, X X \\
\text { Tomografia computadorizada osso } \\
\text { temporal: à E: agenesia do conduto } \\
\text { auditivo externo; deformidade da caixa } \\
\text { timpânica com posicionamento caudal e } \\
\text { deformidade da cadeia ossicular; } \\
\text { malformação coclear com ausência do } \\
\text { modíolo, do vestíbulo, do canal } \\
\text { semicircular superior e posterior; } \\
\text { agenesia pavilhão auricular. À D: } \\
\text { conduto auditivo externo pérvio e com } \\
\text { pequenas dimensões; velamento } \\
\text { completo da caixa timpânica; cadeia } \\
\text { ossicular com morfologia anômala em } \\
\text { sua porção superior. } \\
\text { Tomografia computadorizada tórax: } \\
\text { pulmão E não vizualizado; opacidade } \\
\text { para-vertebral na base direita. } \\
\text { RX tórax: hemivértebras torácicas, } \\
\text { evidenciando-se escoliose dextroconvexa } \\
\text { local; possível fusão parcial dos } \\
\text { primeiros arcos costais à E; opacificação } \\
\text { do hemitórax E, observando-se desvio } \\
\text { mediastinal para este lado; discreto } \\
\text { velamento retículo-nodular peri-hilar à } \\
\text { D, mais evidente na base correspondente. } \\
\text { Avaliação audiológica:DA condutiva } \\
\text { moderada à D e sensorioneural } \\
\text { profunda à E }\end{array}$ & $\begin{array}{l}\text { Espectro oculoauriculovertebral } \\
\text { (etiologia heterogênea) }\end{array}$ \\
\hline
\end{tabular}


Continuação TABELA 11: Dados dos indivíduos com deficiência auditiva e envolvimento de orelha externa

\begin{tabular}{|c|c|c|c|c|c|c|}
\hline Indivíduo & Sexo & Idade & Sinais clínicos & $\begin{array}{l}\text { Dados gestacionais e perinatais/ } \\
\text { antecedentes pessoais e familiais }\end{array}$ & $\begin{array}{l}\text { Exames complementares e } \\
\text { caracterização da DA }\end{array}$ & $\begin{array}{l}\text { Hipótese diagnóstica } \\
\text { (modelo de herança) }\end{array}$ \\
\hline $48^{*}$ & $\mathrm{~F}$ & $27 \mathrm{a}$ & $\begin{array}{l}\text { Hipoplasia do arco zigomático; fendas } \\
\text { palpebrais oblíquas para baixo; } \\
\text { micrognatia acentuada; orelhas } \\
\text { proeminentes deficiência auditiva }\end{array}$ & $\begin{array}{l}\text { IMC: 23a / IPC: ? G4P3A1 } \\
\text { Sem intercorrências gestacionais. } \\
\text { Parto normal; gestação a termo. } \\
\text { PN=? } \\
\text { EN=? } \\
\text { Filho igualmente afetado. }\end{array}$ & $\begin{array}{l}\text { Avaliação audiológica:DA } \\
\text { sensorioneural moderada à D e DA } \\
\text { condutiva leve à E }\end{array}$ & $\begin{array}{c}\text { Síndrome de Treacher-Collins } \\
\text { (HAD/HAR) }\end{array}$ \\
\hline 49 & $\mathrm{~F}$ & $10 \mathrm{~m}$ & $\begin{array}{l}\text { Estreitamento bitemporal; hipoplasia do } \\
\text { arco zigomático; fendas palpebrais } \\
\text { oblíquas para baixo; ectrópio bilateral; } \\
\text { micrognatia; glossoptose; microtia tipo } \\
\text { II bilaterak atresia MAE bilateral } \\
\text { deficiência auditiva }\end{array}$ & $\begin{array}{l}\text { IMC: } 30 \mathrm{a} / \text { IPC: } 30 \mathrm{a} \quad \text { G4P4A0 } \\
\text { Hipertensão arterial no início gestacional. } \\
\text { Ameaços de parto prematuro a partir do } 5^{\circ} \\
\text { mês. } \\
\text { Parto cesáreo; gestação de } 8 \text { meses e } 15 \\
\text { dias. } \\
\mathrm{PN}=2.750 \mathrm{~g}(\mathrm{p}=10) \\
\mathrm{EN}=45 \mathrm{~cm}(\mathrm{p}<3) \\
\text { Sem intercorrências perinatais. } \\
\text { Avô paterno, pai, irmã e vários tios } \\
\text { paternos com fendas palpebrais oblíquas } \\
\text { para baixo e discreta micrognatia. }\end{array}$ & $\begin{array}{l}\text { Avaliação audiológica:DA condutiva } \\
\text { moderada bilateral }\end{array}$ & $\begin{array}{c}\text { Síndrome de Treacher-Collins } \\
\text { (HAD/HAR) }\end{array}$ \\
\hline 50 & M & $16 \mathrm{a}$ & $\begin{array}{l}\text { Assimetria facial; hipoplasia do arco } \\
\text { zigomático; fendas palpebrais pequenas e } \\
\text { oblíquas para baixo; coloboma de } \\
\text { pálpebra inferior bilateralmente; } \\
\text { micrognatia; palato alto; microtia tipo I } \\
\text { bilaterab deficiência auditiva }\end{array}$ & $\begin{array}{l}\text { IMC: } 21 \mathrm{a} / \text { IPC: } 21 \mathrm{a} \quad \text { G3P2A1 } \\
\text { Sem intercorrências gestacionais. } \\
\text { Parto normal; gestação a termo. } \\
\mathrm{PN}=3.000 \mathrm{~g}(10<\mathrm{p}<25) \\
\mathrm{EN}=\text { ? } \\
\text { Sem intercorrências perinatais. } \\
\text { Caso isolado. }\end{array}$ & $\begin{array}{l}\text { Cariótipo: } 46, X Y \\
\text { Avaliação audiológica:DA condutiva } \\
\text { moderada à D e severa à E }\end{array}$ & $\begin{array}{c}\text { Síndrome de Treacher-Collins } \\
\text { (HAD/HAR) }\end{array}$ \\
\hline
\end{tabular}


Continuação TABELA 11: Dados dos indivíduos com deficiência auditiva e envolvimento de orelha externa

\begin{tabular}{|c|c|c|c|c|c|c|}
\hline Indivíduo & Sexo & Idade & Sinais clínicos & $\begin{array}{l}\text { Dados gestacionais e perinatais/ } \\
\text { antecedentes pessoais e familiais }\end{array}$ & $\begin{array}{l}\text { Exames complementares e } \\
\text { caracterização da DA }\end{array}$ & $\begin{array}{l}\text { Hipótese diagnóstica } \\
\text { (modelo de herança) }\end{array}$ \\
\hline 51 & $\mathrm{~F}$ & 4a $10 \mathrm{~m}$ & $\begin{array}{l}\text { Hipoplasia arco zigomático; fendas } \\
\text { palpebrais oblíquas para baixo; } \\
\text { micrognatia;microtia tipo II à D e tipo I } \\
\text { à E; atresia MAE bilateral deficiência } \\
\text { auditiva; hipoplasia do } 10 \text { raio bilateral } \\
\text { com camptodactilia à D e clinodactilia } \\
\text { ulnar à E }\end{array}$ & $\begin{array}{l}\text { IMC: } 37 \mathrm{a} / \text { IPC: } 31 \mathrm{a} \quad \text { G8P7A1 } \\
\text { Sem intercorrências gestacionais. } \\
\text { Parto normal; gestação a termo. } \\
\mathrm{PN}=2.250 \mathrm{~g}(\mathrm{p}<3) \\
\mathrm{EN}=\text { ? } \\
\text { Sem intercorrências perinatais. } \\
\text { Mãe com discreta micrognatia. }\end{array}$ & $\begin{array}{l}\text { Avaliação audiológicaDA condutiva } \\
\text { moderada bilateral }\end{array}$ & $\begin{array}{l}\text { Síndrome de Nager } \\
\text { (HAD/HAR) }\end{array}$ \\
\hline 52 & $\mathrm{~F}$ & $13 \mathrm{a} 2 \mathrm{~m}$ & $\begin{array}{l}\text { Hipoplasia arco zigomático; fendas } \\
\text { palpebrais pequenas e oblíquas para } \\
\text { baixo; coloboma de pálpebra; ponte nasal } \\
\text { alongada; micrognatia; fissura de palato; } \\
\text { glossoptose; microtia tipo I bilterał } \\
\text { atresia MAE bilaterał deficiência } \\
\text { auditiva; agenesia } 1^{\circ} \text { raio bilateral; } 2^{\circ} \\
\text { dígito alargado à E com clinodactilia } \\
\text { radial; háluces com baixa implantação; } 2^{\circ} \\
\text { e } 3^{\circ} \text { artelhos alon gados bilateralmente }\end{array}$ & $\begin{array}{l}\text { IMC: } 32 \mathrm{a} / \text { IPC: } 46 \mathrm{a} \quad \text { G4P4A0 } \\
\text { Sem intercorrências gestacionais. } \\
\text { Parto cesáreo; gestação de } 8 \text { meses e } 15 \\
\text { dias. } \\
\mathrm{PN}=2.800 \mathrm{~g}(10<\mathrm{p}<25) \\
\mathrm{EN}=48 \mathrm{~cm}(10<\mathrm{p}<25) \\
\text { Aos } 2 \mathrm{~m} \text { de idade, realizou traqueostomia, } \\
\text { permanecendo até os } 10 \mathrm{~m} \text { de idade. Neste } \\
\text { tempo, realizou glossopexia e } \\
\text { glossoplastia. } \\
\text { Aos } 3 \mathrm{~m} \text { idade, apresentou } 1 \text { episódio de } \\
\text { broncopneumonia. } \\
\text { Caso isolado. }\end{array}$ & $\begin{array}{l}\text { Cariótipo: } 46, \mathrm{XX} \\
\text { Avaliação audiológicaDA condutiva } \\
\text { moderada bilateral }\end{array}$ & $\begin{array}{l}\text { Síndrome de Nager } \\
\text { (HAD/HAR) }\end{array}$ \\
\hline
\end{tabular}


Continuação TABELA 11: Dados dos indivíduos com deficiência auditiva e envolvimento de orelha externa

\begin{tabular}{|c|c|c|c|c|c|c|}
\hline Indivíduo & Sexo & Idade & Sinais clínicos & $\begin{array}{l}\text { Dados gestacionais e perinatais/ } \\
\text { antecedentes pessoais e familiais }\end{array}$ & $\begin{array}{l}\text { Exames complementares e } \\
\text { caracterização da DA }\end{array}$ & $\begin{array}{l}\text { Hipótese diagnóstica } \\
\text { (modelo de herança) }\end{array}$ \\
\hline 53 & M & 1a $5 \mathrm{~m}$ & $\begin{array}{l}\text { Obstrução do canal lacrimal à } \mathrm{D} \text {; } \text { orelhas } \\
\text { proeminentes com implantação } \\
\text { discretamente baixa; anti-hélix } \\
\text { simplificado à D; fístula pré-auricular } \\
\text { bilateral; deficieincia auditiva; fístula } \\
\text { branquial à D; displasia ungueal mãos e } \\
\text { pés; hipoplasia ungueal do } 5^{\circ} \text { artelho } \\
\text { bilateral; } \\
\text { ADNM }\end{array}$ & $\begin{array}{l}\text { IMC: } 30 \mathrm{a} / \text { IPC: } 31 \mathrm{a} \quad \text { G1P1A0 } \\
\text { Envelhecimento precoce da placenta no } \\
8^{\circ} \text { mês gestacional. } \\
\text { Parto cesáreo; gestação de } 8 \text { meses e } \\
15 \text { dias. } \\
\mathrm{PN}=2.830 \mathrm{~g}(\mathrm{p}=10) \\
\mathrm{EN}=48 \mathrm{~cm}(3<\mathrm{p}<10) \\
\text { Sem intercorrências perinatais. } \\
\text { Caso isolado. }\end{array}$ & $\begin{array}{l}\text { Cariótipo: } 46, \mathrm{XY} \\
\text { Ultrassom abdominal total: normal } \\
\text { Avaliação audiológica:DA } \\
\text { sensorioneural profunda bilateral }\end{array}$ & $\begin{array}{l}\text { Síndrome branquio-oto-renal } \\
\text { (HAD) }\end{array}$ \\
\hline 54 & M & $9 \mathrm{a} 7 \mathrm{~m}$ & $\begin{array}{l}\text { Fendas palpebrais estreitas; estrabismo } \\
\text { convergente; obstrução canal lacrimal } \\
\text { bilateral; microtia tipo II à D ("cupped } \\
\text { shaped") e tipo I à E; fístula branquial } \\
\text { bilateral; apêndice pré-auricular à D; } \\
\text { deficiência auditiva ADNPM }\end{array}$ & $\begin{array}{l}\text { IMC: } 22 \mathrm{a} / \text { IPC: } 25 \mathrm{a} \quad \text { G3P3A0 } \\
\text { Sem intercorrências gestacionais. } \\
\text { Parto normal; gestação a termo. } \\
\mathrm{PN}=3.090 \mathrm{~g}(10<\mathrm{p}<25) \\
\mathrm{EN}=47 \mathrm{~cm}(\mathrm{p}=3) \\
\text { Sem intercorrências perinatais. } \\
\text { Caso isolado. }\end{array}$ & $\begin{array}{l}\text { Cariótipo: } 46, \mathrm{XY} \\
\text { Tomografia computadorizada osso } \\
\text { temporal: malformação de orelha externa } \\
\text { e média, bilateralmente, com sinais de } \\
\text { ostomastoidite crônica D. } \\
\text { Ultrassom aparelho urinário: normal } \\
\text { Avaliação audiológica: ;DA condutiva } \\
\text { moderada à D e severa à E }\end{array}$ & $\begin{array}{c}\text { Síndrome branquio-oto-renal } \\
\text { (HAD) }\end{array}$ \\
\hline
\end{tabular}


Continuação TABELA 11: Dados dos indivíduos com deficiência auditiva e envolvimento de orelha externa

\begin{tabular}{|c|c|c|c|c|c|c|}
\hline Indivíduo & Sexo & Idade & Sinais clínicos & $\begin{array}{l}\text { Dados gestacionais e perinatais/ } \\
\text { antecedentes pessoais e familiais }\end{array}$ & $\begin{array}{l}\text { Exames complementares e } \\
\text { caracterização da DA }\end{array}$ & $\begin{array}{l}\text { Hipótese diagnóstica } \\
\text { (modelo de herança) }\end{array}$ \\
\hline 55 & $\mathrm{~F}$ & $10 \mathrm{a}$ & $\begin{array}{l}\text { Déficit pré e pós-natal; assimetria facial; } \\
\text { micrognatia; microtia tpo II bilateral } \\
\text { com agenesia MAE; deficiência } \\
\text { auditiva; pescoço curto; cardiopatia } \\
\text { congênita; mãos pequenas; prega palmar } \\
\text { única à E; braquidactilia do } 5^{\circ} \text { dígito; } \\
\text { clinodactilia radial do } 3^{\circ}, 4^{\circ} \text { e } 5^{\circ} \text { dígitos } \\
\text { e ulnar do } 2^{\circ} \text {; displasia ungueal artelhos; } \\
\text { hipopigmentação de pele em tronco e } \\
\text { membros; ADNPM }\end{array}$ & $\begin{array}{l}\text { IMC: } 33 \mathrm{a} / \mathrm{IPC}: 30 \mathrm{a} \quad \mathrm{G} 3 \mathrm{P} 3 \mathrm{~A} 0 \\
\text { Sem intercorrências gestacionais. } \\
\text { Parto normal; gestação a termo. } \\
\mathrm{PN}=2.000 \mathrm{~g}(\mathrm{p}<3) \\
\mathrm{EN}=45 \mathrm{~cm}(\mathrm{p}<3) \\
\text { Necessitou } \mathrm{O} 2 \text { por } 2 \text { dias. } \\
\text { Caso isolado. }\end{array}$ & $\begin{array}{l}\text { Cariótipo: } 46, X X \\
\text { Ecocardiograma: CIA } \\
\text { Avaliação audiológica: DA condutiva } \\
\text { bilateral }\end{array}$ & Sem definição diagnóstica \\
\hline
\end{tabular}

$\mathrm{M}=$ masculino; $\mathrm{F}=$ feminino; $\mathrm{a} / \mathrm{m}=\mathrm{idade}$ em ano(s) e mês(es) na primeira avaliação; IMC=idade materna na concepção; IPC=idade paterna na concepç̃o; $\mathrm{G}_{-} \mathrm{P} \_\mathrm{A}=\mathrm{A}^{\circ}{ }^{\mathrm{d}}$ de gestações, partos e abortos; $\mathrm{PN}=$ peso ao nascimento; EM=estatura ao nascimento; $\mathrm{PC}=$ perímetro cefálico; $\mathrm{p}=$ percentil; $\mathrm{DA}=$ deficiência auditiva; $\mathrm{D}=$ direita; $\mathrm{E}=$ esquerda; $\mathrm{ADNPM}=$ atraso no desenvolvimento neuropsicomotor; $\mathrm{MAE}=$ meato auditivo externo; ${ }^{*}=$ consangüinidade parental; $\mathrm{HAD}=$ herança
autossômica dominante; $\mathrm{HAR}=$ herança autossômica recessiva 


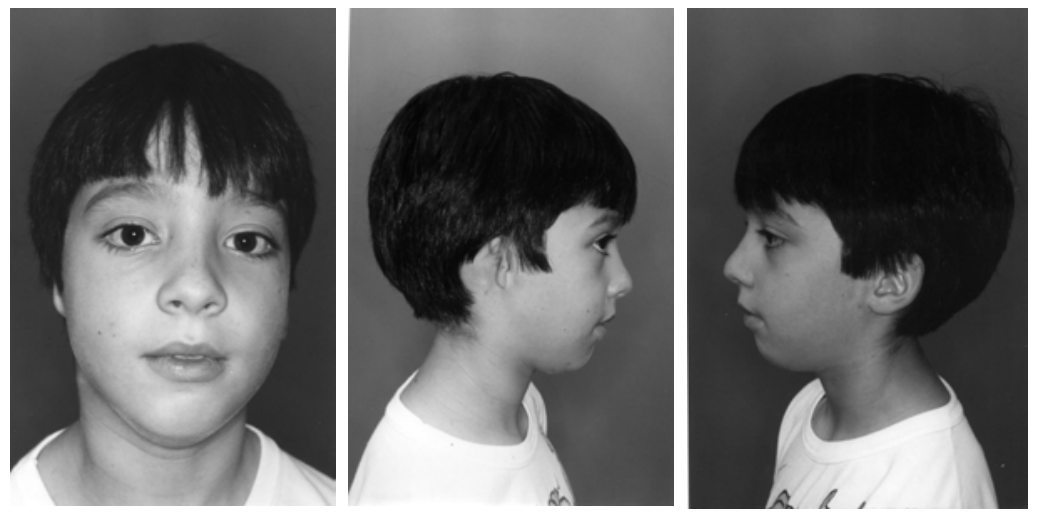

FIGURA 44: Aspectos clínicos do Caso 30
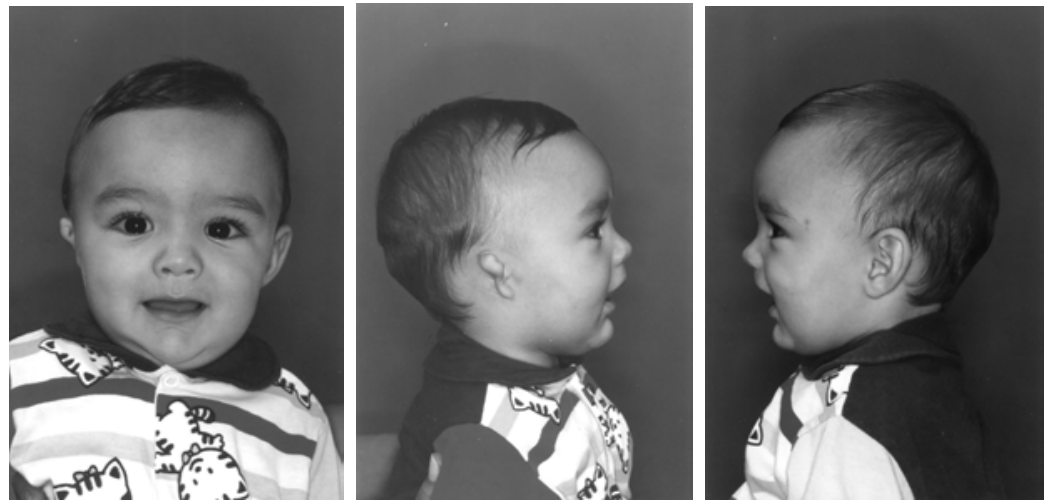

FIGURA 45: Aspectos clínicos do Caso 31
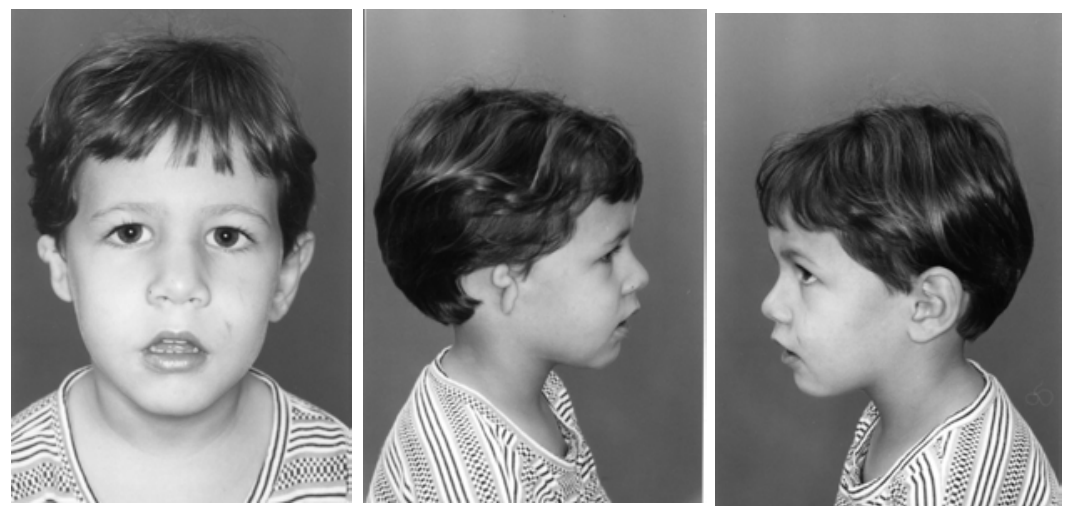

FIGURA 46: Aspectos clínicos do Caso 32 

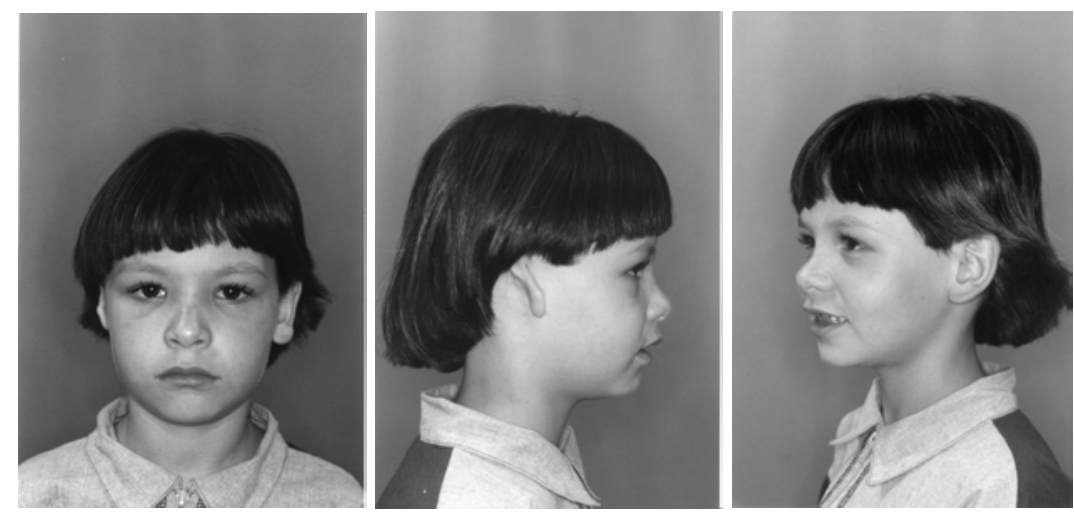

FIGURA 47: Aspectos clínicos do Caso 33

I

III

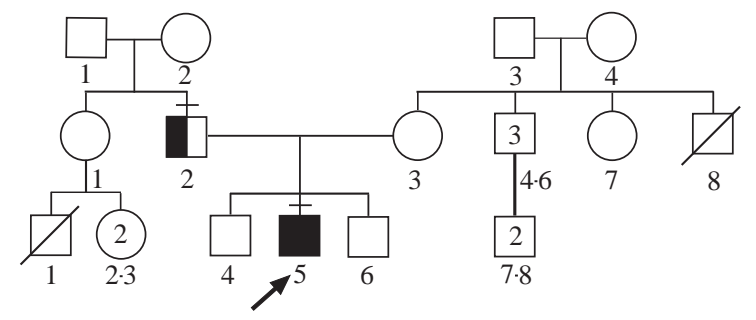

Propósito

(1 Agenesia CAE unilateral D

FIGURA 48: Heredograma da família do Caso 33
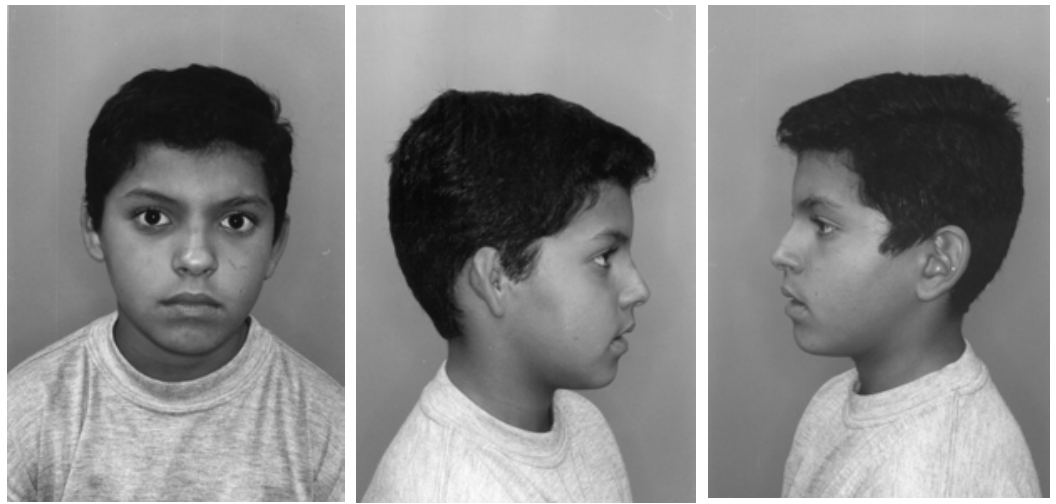

FIGURA 49: Aspectos clínicos do Caso 34 

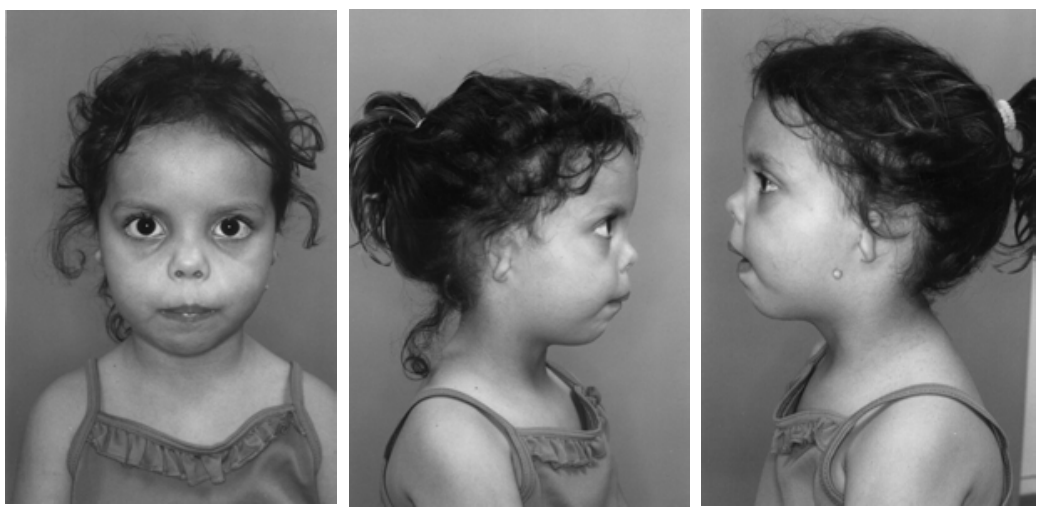

FIGURA 50: Aspectos clínicos do Caso 35
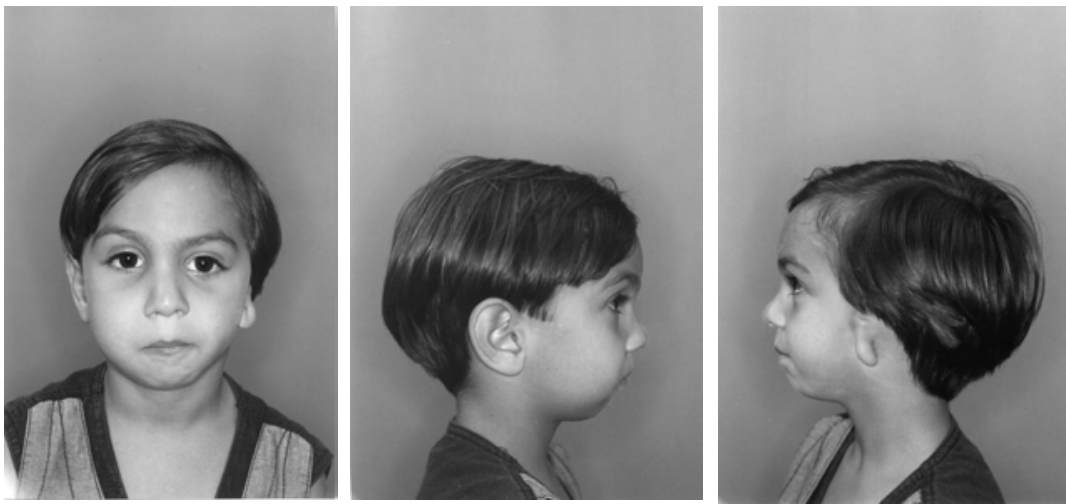

FIGURA 51: Aspectos clínicos do Caso 36
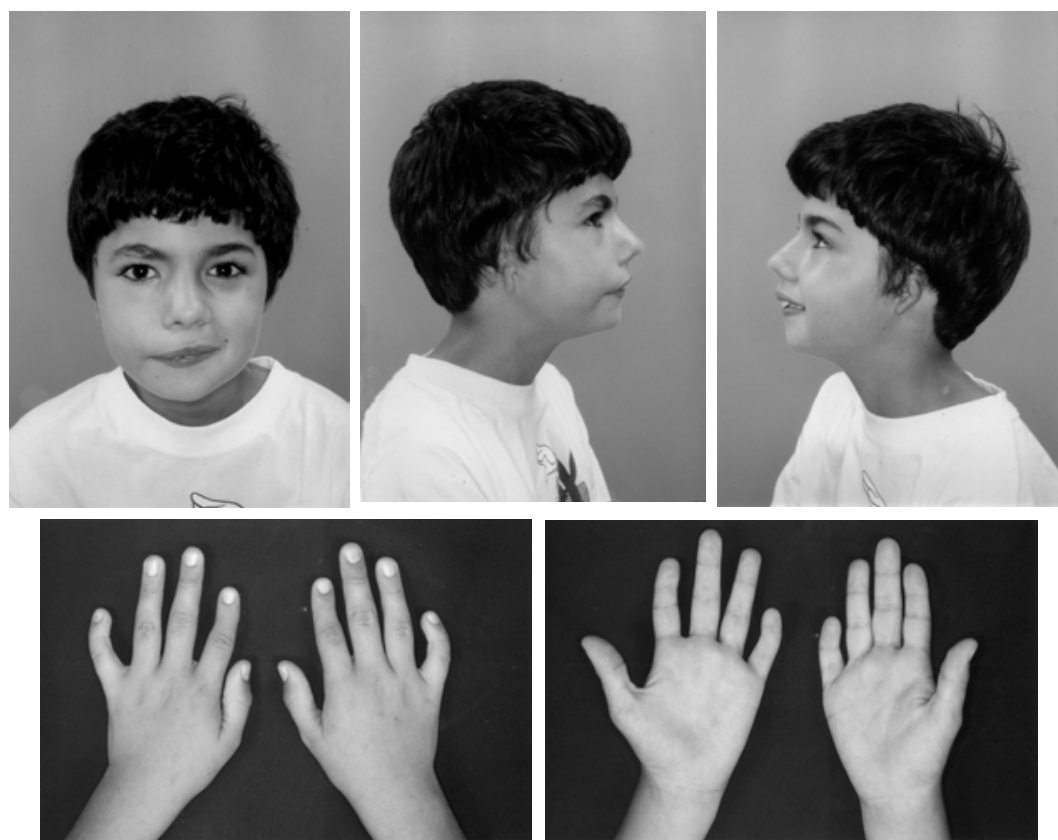

FIGURA 52: Aspectos clínicos do Caso 37 

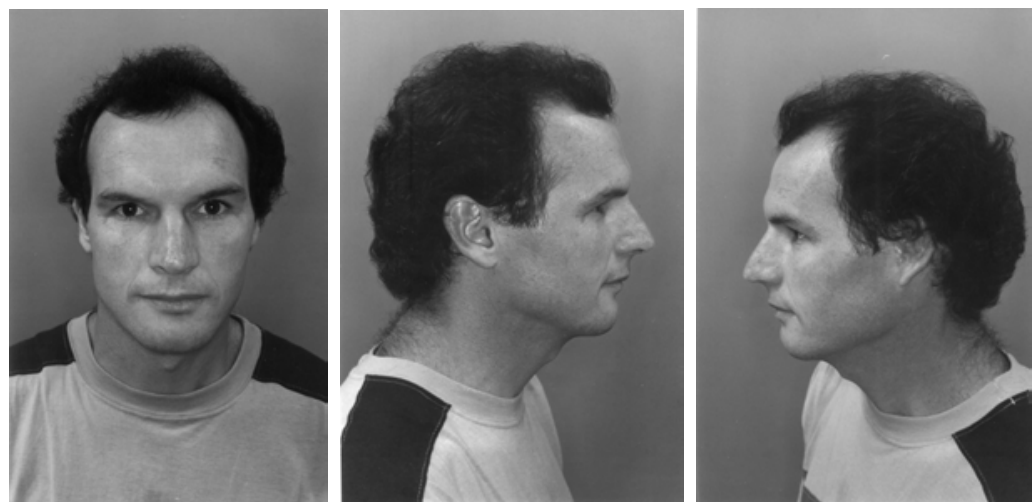

FIGURA 53: Aspectos clínicos do genitor do Caso 37

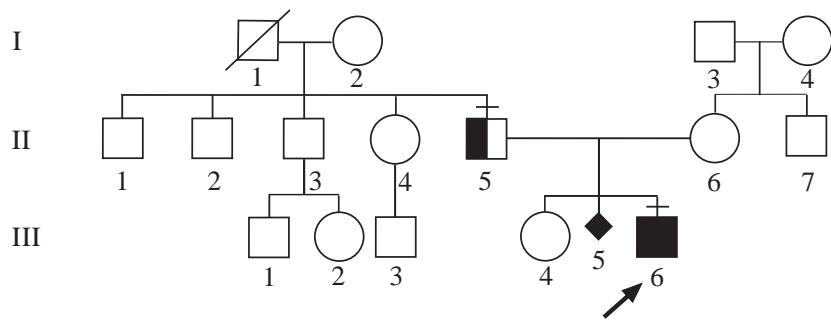

Propósito

Microtia tipo II à E; agenesia CAE à E

FIGURA 54: Heredograma da família do Caso 37 

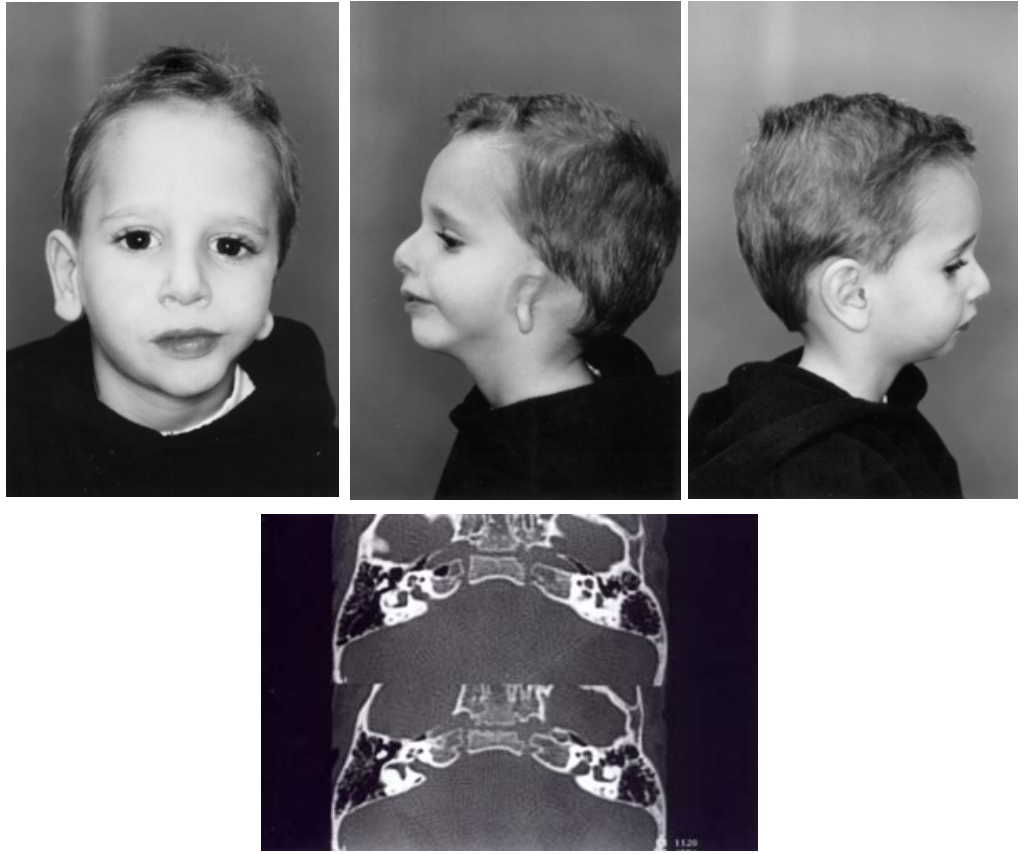

FIGURA 55: Aspectos clínicos e tomográficos do Caso 38

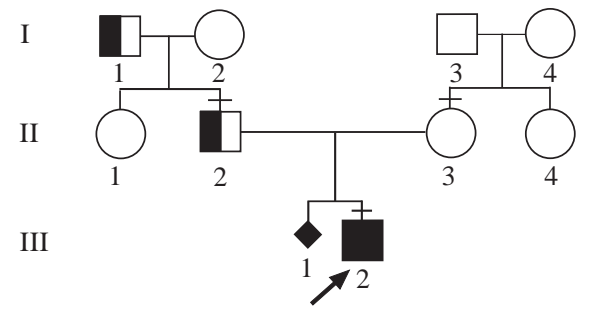

Propósito

D Apêndice pré-auricular à E

FIGURA 56: Heredograma da família do Caso 38 

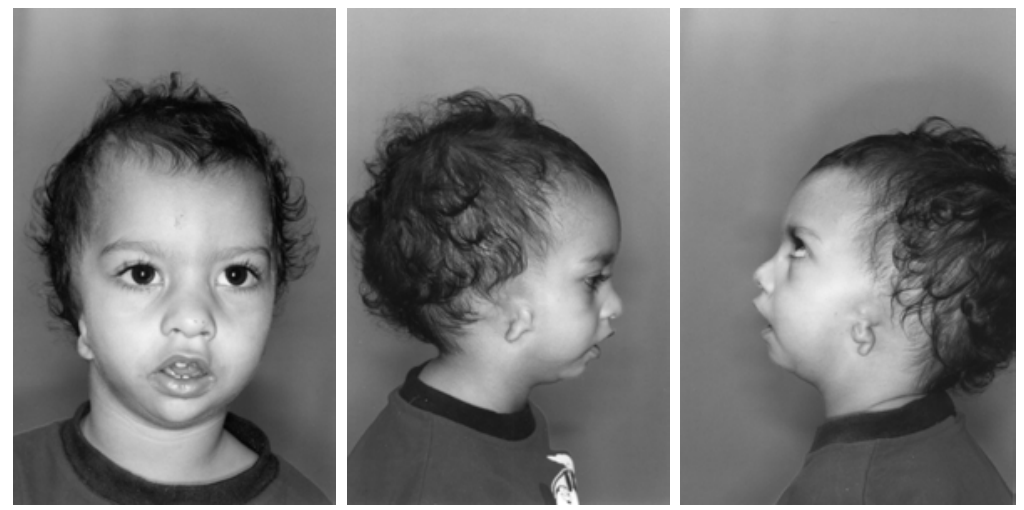

FIGURA 57: Aspectos clínicos do Caso 39
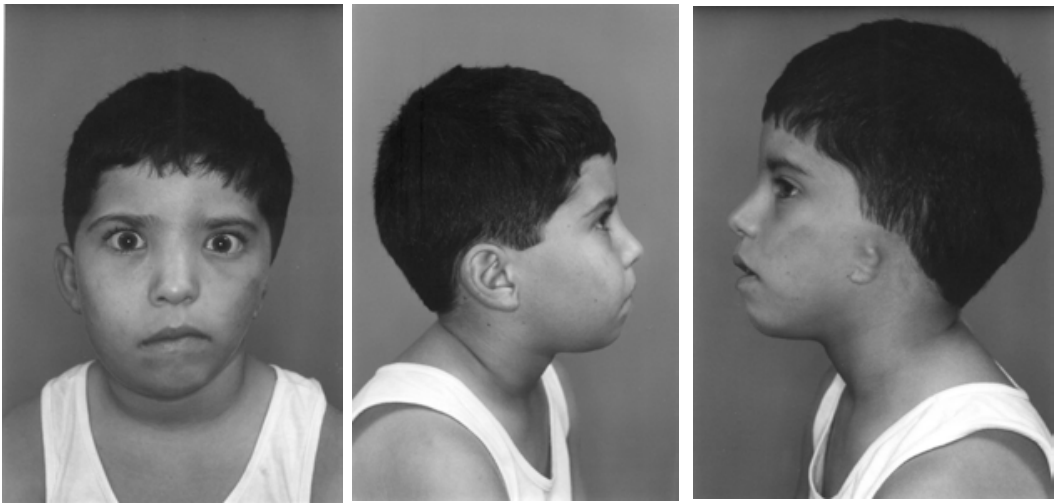

FIGURA 58: Aspectos clínicos do Caso 40
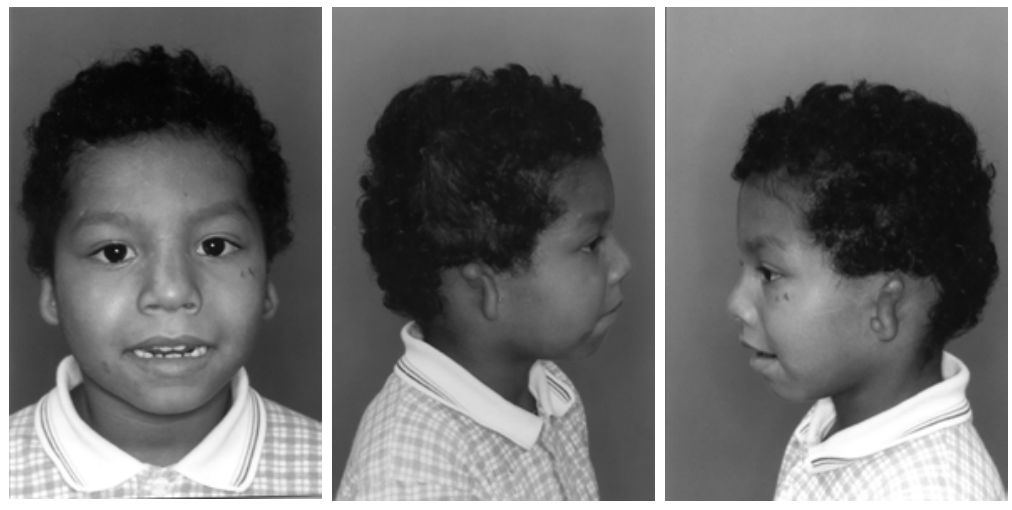

FIGURA 59: Aspectos clínicos do Caso 41 

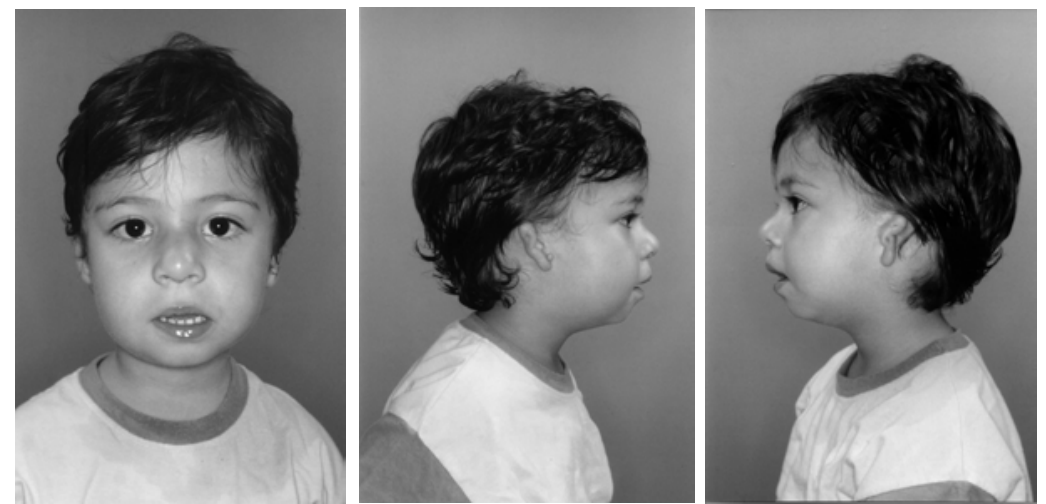

FIGURA 60: Aspectos clínicos do Caso 42
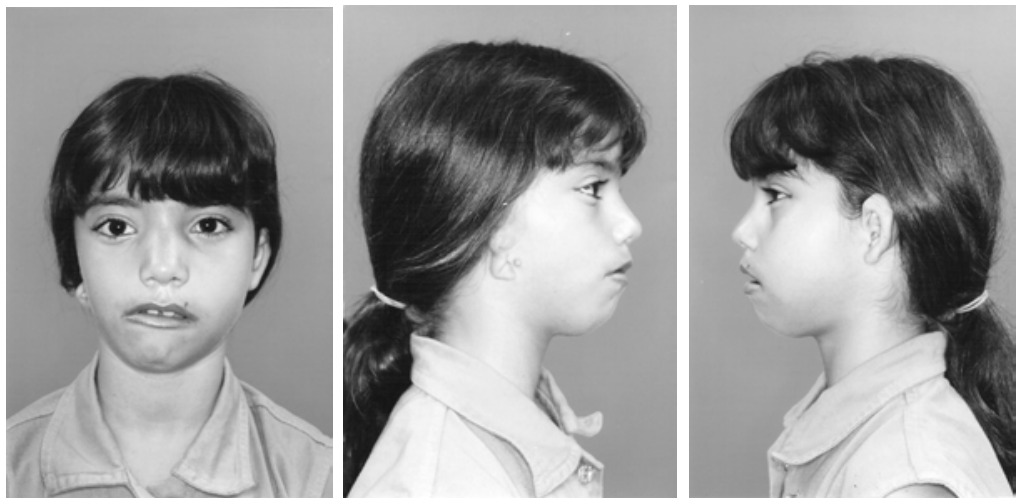

FIGURA 61: Aspectos clínicos do Caso 43

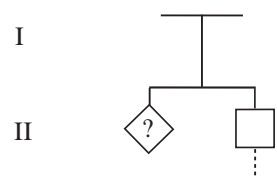

III

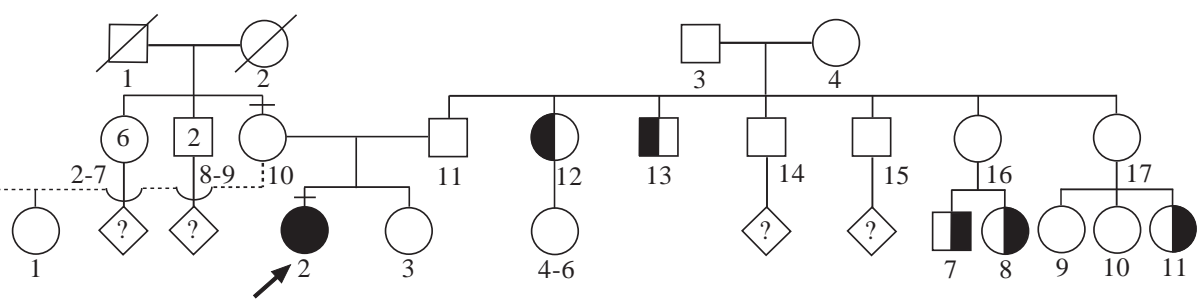

(1) Microtia unilateral

(1) Apêndice pré-auricular unilateral

FIGURA 62: Heredograma da família do Caso 43 

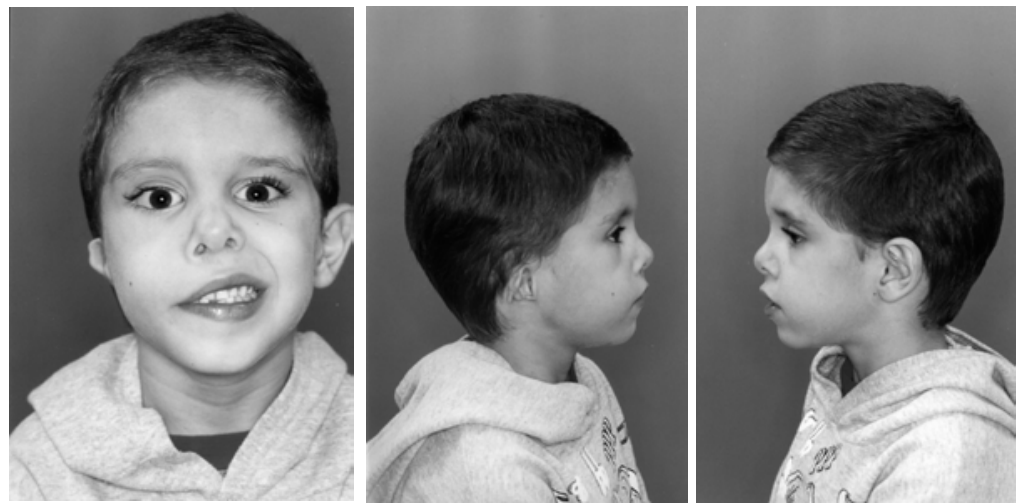

FIGURA 63: Aspectos clínicos do Caso 44
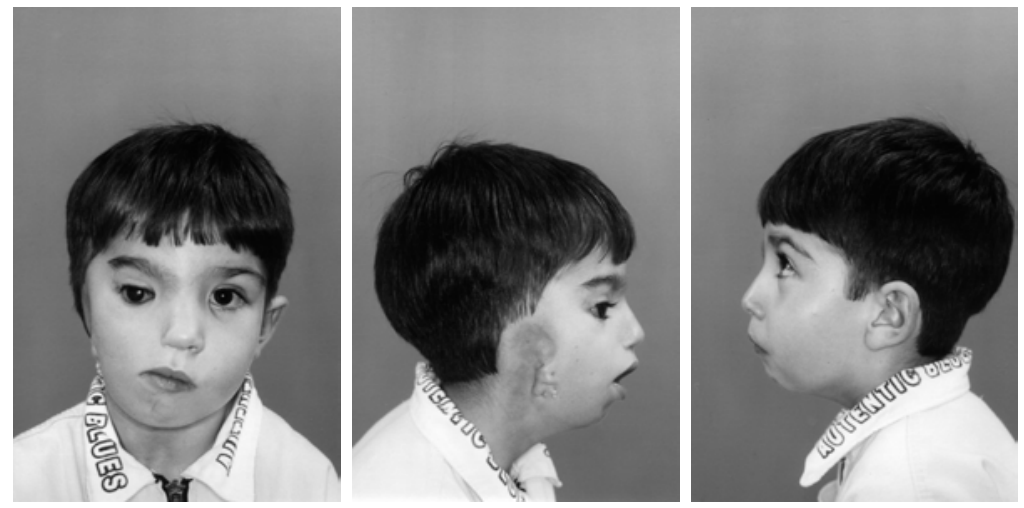

FIGURA 64: Aspectos clínicos do Caso 45
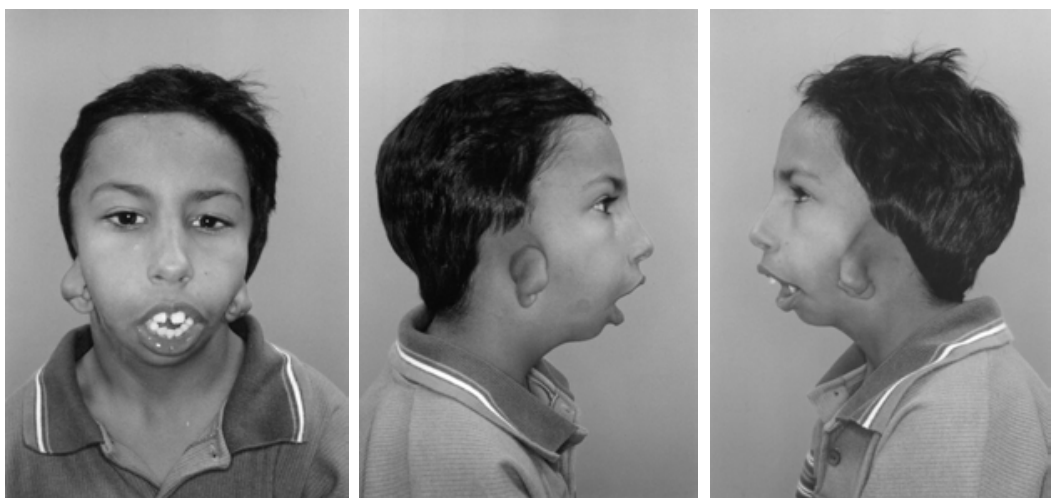

FIGURA 65: Aspectos clínicos do Caso 46 

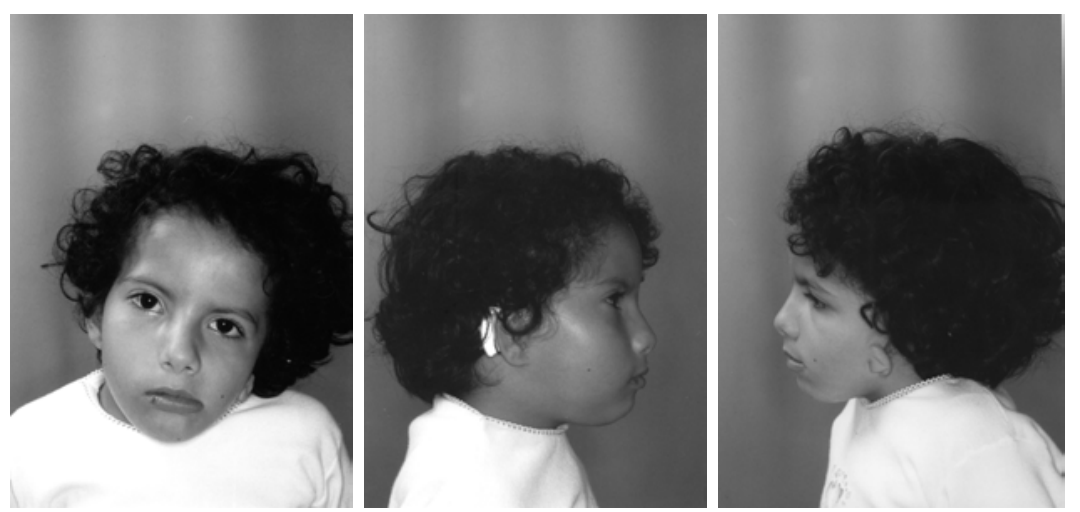

FIGURA 66: Aspectos clínicos do Caso 47 

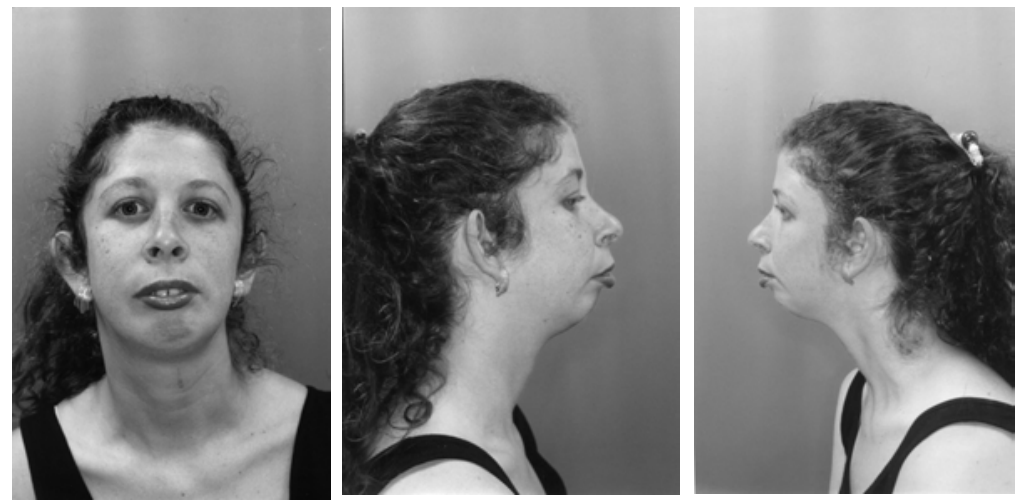

FIGURA 67: Aspectos clínicos do Caso 48

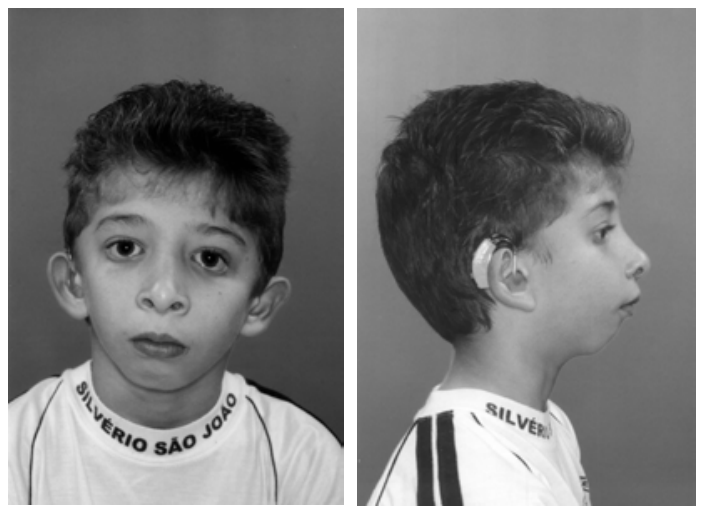

FIGURA 68: Aspectos clínicos do filho do Caso 48

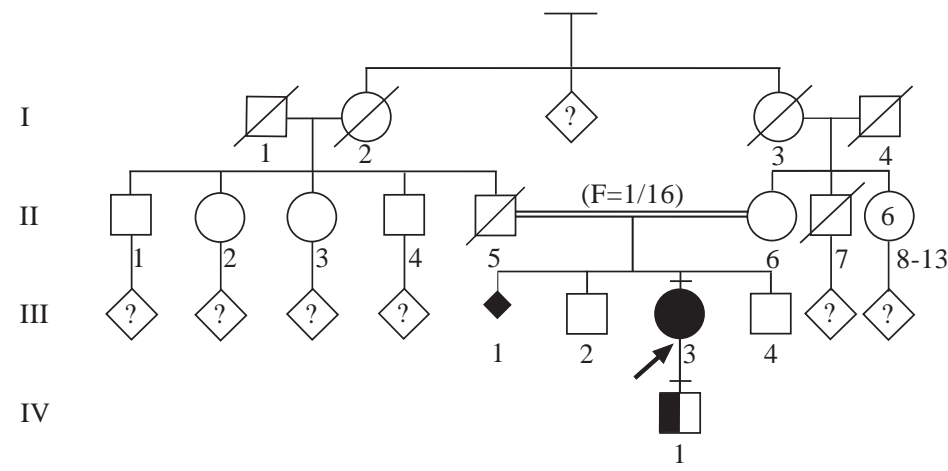

- Propósita

- Hipoplasia do arco zigomático; fendas palpebrais oblíquas para baixo; fissura de palato; micrognatia

FIGURA 69: Heredograma da família do Caso 48 

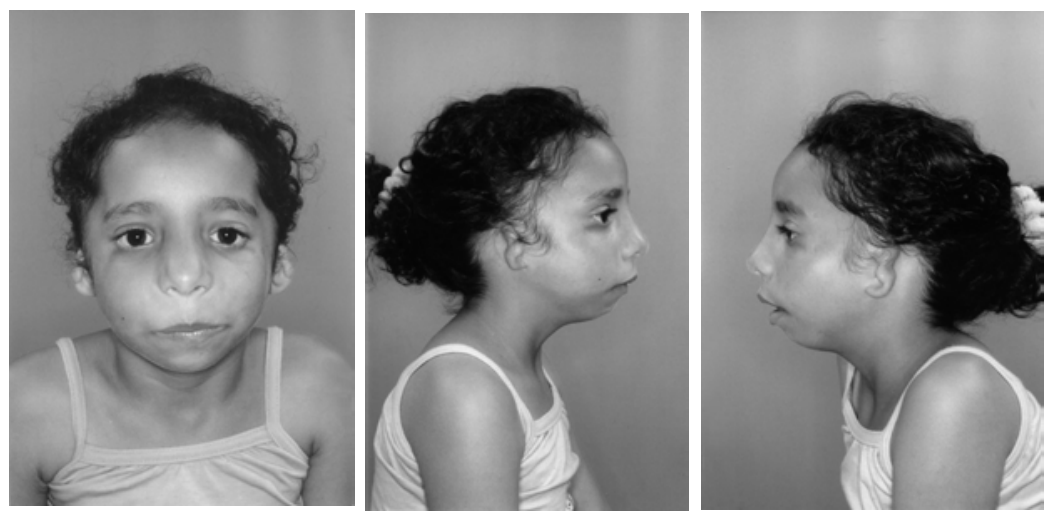

FIGURA 70: Aspectos clínicos do Caso 49

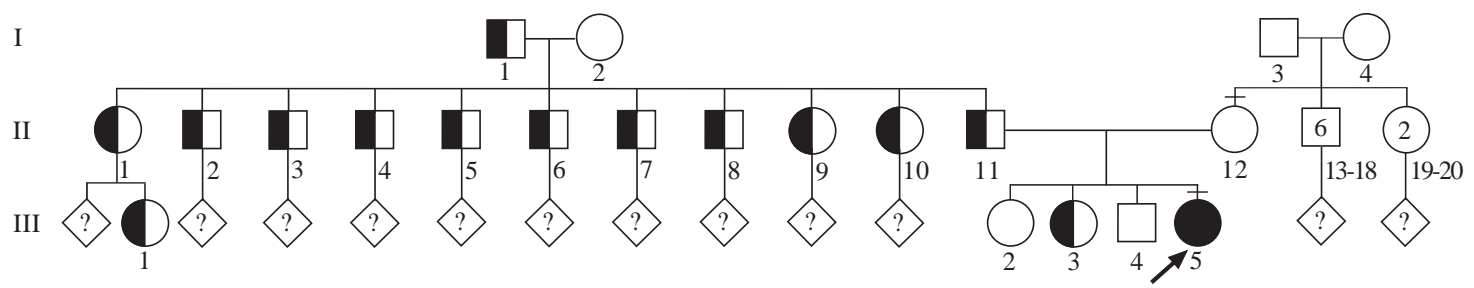

Propósita

Fendas palpebrais oblíquas para baixo; micrognatia

FIGURA 71: Heredograma da família do Caso 49
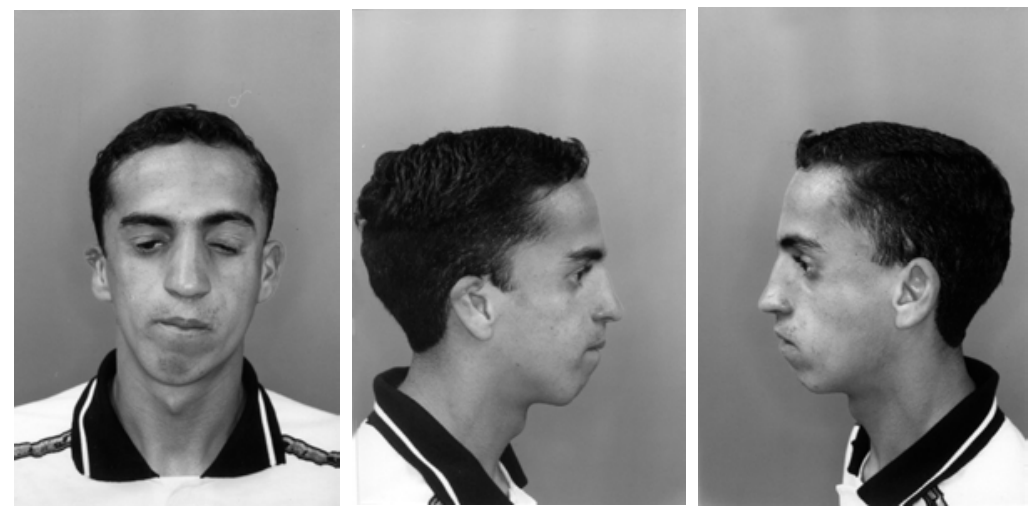

FIGURA 72: Aspectos clínicos do Caso 50 

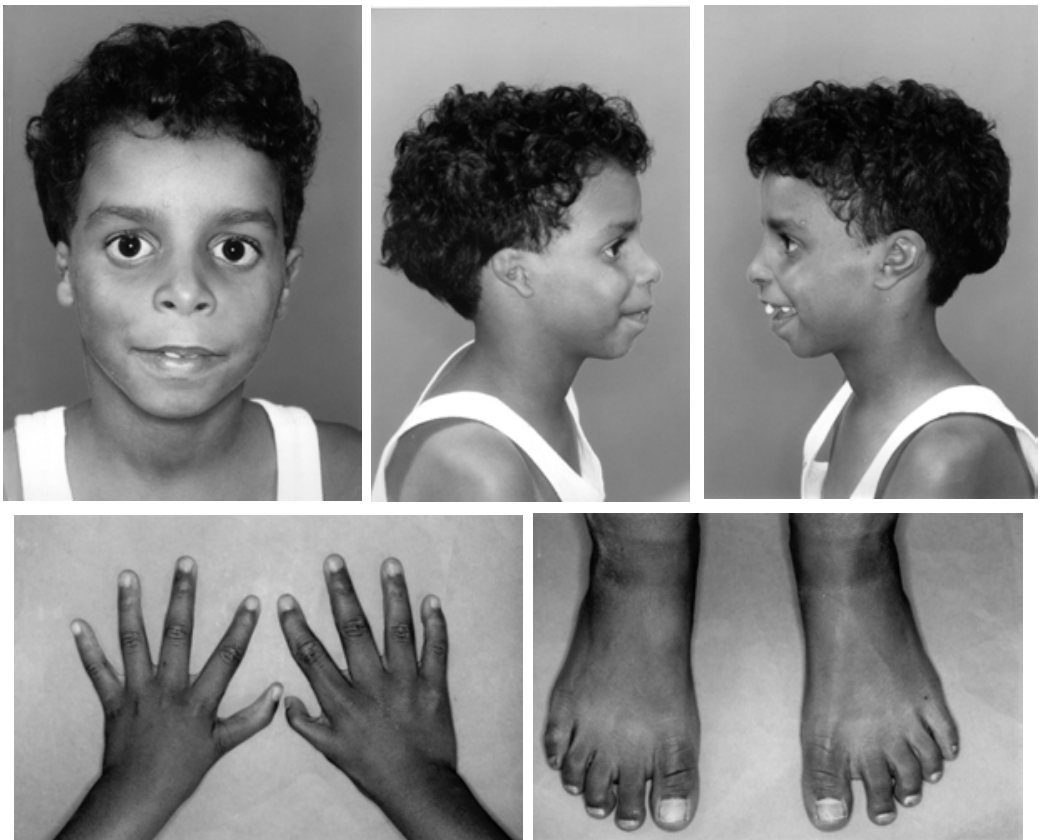

FIGURA 73: Aspectos clínicos do Caso 51
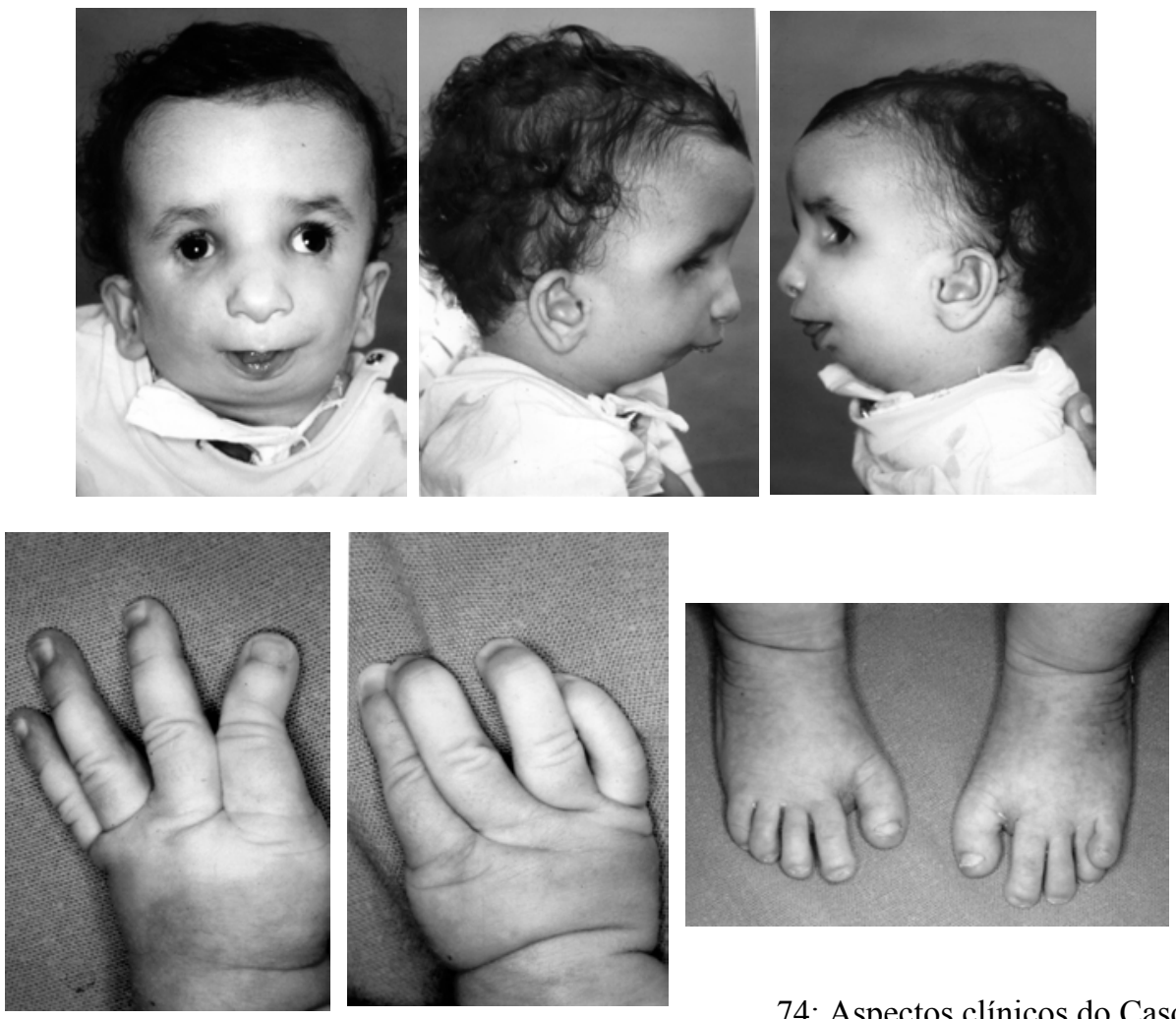

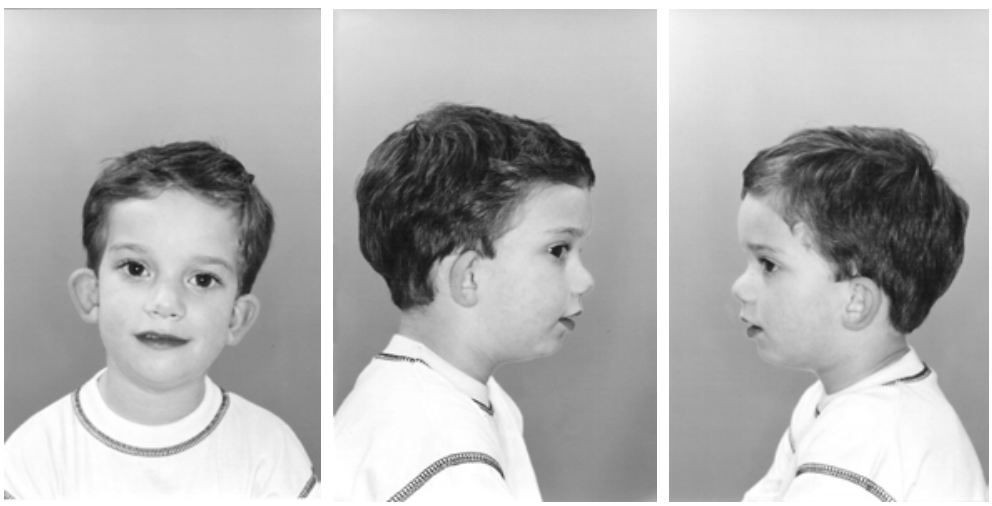

FIGURA 75: Aspectos clínicos do Caso 53
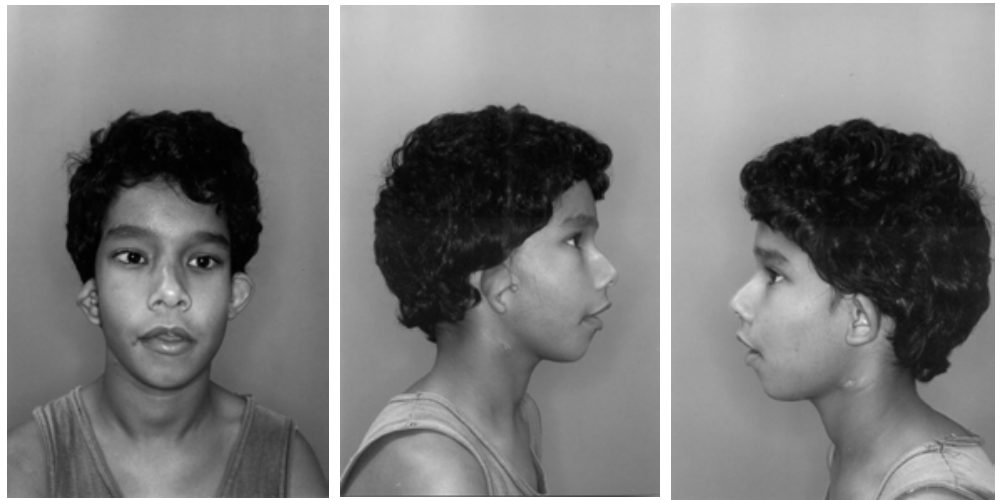

FIGURA 76: Aspectos clínicos do Caso 54 

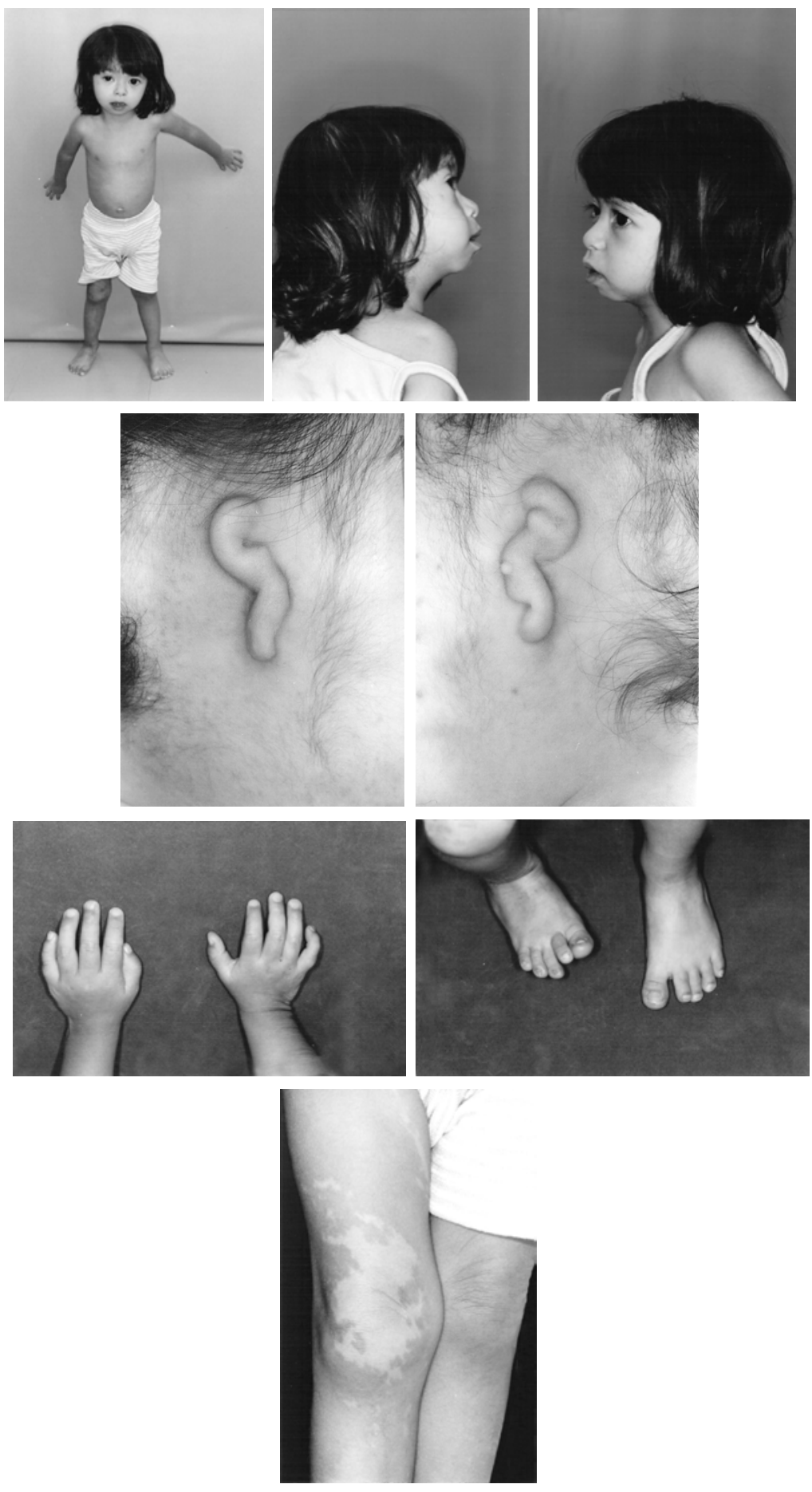

FIGURA 77: Aspectos clínicos do Caso 55 
Defeitos estruturais de orelha externa, média e interna representam uma classe significativa de anomalias congênitas, devido à alta freqüência e ao grande impacto nos indivíduos acometidos. No tocante à orelha externa, observa-se desde simples redução do tamanho da orelha até grave defeito do pavilhão auricular. Esta anomalia, sinal cardinal dos Casos 30 a 55 (Tabela 11), é resultante de alterações no desenvolvimento do primeiro e segundo arcos branquiais. Podem ocorrer isoladamente ou como parte do quadro clínico de um número significativo de síndromes (Kaye et al 1989), como por exemplo: síndrome de Nager (OMIM 154400), síndrome de TreacherCollins (OMIM 154500), síndrome branquio-oto-renal (BOR - OMIM 113650), síndrome da atresia aural, microtia e deficiência auditiva (OMIM 251800), espectro oculoauriculovertebral (EOAV - OMIM 164210), entre outras. Em alguns desses quadros, além do envolvimento dos arcos branquiais, a presença de sinais clínicos peculiares permite o pronto estabelecimento diagnóstico. Por outro lado, outras síndromes apresentam acentuada sobreposição clínica e, nem sempre, a diferenciação é possível, como no caso do EOAV e da síndrome da atresia aural, microtia e deficiência auditiva condutiva. Essa é uma condição rara e, até o momento, somente casos familiais foram descritos. Herança autossômica recessiva foi sugerida em quatro famílias (Ellwood et al 1968, Konigsmark et al 1972, Schmid et al 1985, Strisciuglio et al 1986) e, dominante, em outras seis (Guizar-Vazquez et al 1978, Zankl e Zang 1979, SanchezCorona et al 1982, Oliveira et al 1989, Orstavik et al 1990, Gupta e Patton 1995). Variabilidade clínica com manifestações de leve a grave (inter e intrafamilial) foi observada tanto na forma dominante quanto na recessiva. Outras anomalias de primeiro e segundo arcos branquiais, tais como assimetria facial, apêndice pré-auricular e macrostomia unilateral, foram citadas em algumas das famílias tanto com a forma dominante quanto recessiva. A possibilidade de esses indivíduos fazerem parte do EOAV foi comentada pelos autores (Guizar-Vazquez et al 1978, Zankl e Zang 1979, Strisciuglio et al 1986, Oliveira et al 1989). Segundo Gorlin et al (1995), considera-se síndrome da atresia aural, microtia e deficiência auditiva condutiva, apenas na presença destes três achados clínicos. Esses autores mencionam, ainda, que as alterações de orelha diferem nas formas dominante e recessiva, sendo mais grave nessa última. Os Casos 30, 31, 32, 33 e 34 (Tabela 11; Figuras 44, 45, 46, 47 e 49, respectivamente), apresentaram um padrão de alteração de orelha externa e de perda auditiva, sem outras anomalias associadas, o que confere o diagnóstico de síndrome da atresia aural, microtia 
e perda auditiva condutiva. A presença de agenesia do canal auditivo externo e de perda auditiva condutiva no genitor do Caso 33 (Figura 48; III-5), sugere transmissão autossômica dominante. Para os demais (casos isolados), mutação nova ou herança autossômica recessiva devem ser consideradas. Um outro subgrupo de indivíduos desse grupo (Casos 35, 36, 37, 38, 39 e 40 - Tabela 11; Figuras 50, 51, 52, 55, 57 e 58, respectivamente), apresentou assimetria facial em associação a atresia aural, microtia e deficiência auditiva condutiva. A presença de anomalias de primeiro e de segundo arcos branquiais, em familiares dos Casos 37 (Figura 54; II-5) e 38 (Figura 56; I-1 e II-2), sugere modelo de herança autossômica dominante. Considerando que a literatura é controversa em relação aos critérios para o EOAV e, ainda, que a síndrome da atresia aural, microtia e perda auditiva condutiva encontra-se em fase inicial de delineamento, não foi possível excluir qualquer um desses quadros para os Casos de 35 a 40. Já, os Casos 41, 42 e 43 (Tabela 11; Figuras 59, 60 e 61, respectivamente), da presente amostra, apresentaram, além da atresia aural, microtia e perda auditiva condutiva, manifestações como assimetria facial, apêndice pré-auricular e macrostomia, comuns nos indivíduos com EOAV. Apesar dos relatos de indivíduos, com este conjunto de anomalias, terem sido descritos como tendo a síndrome da atresia aural, microtia e perda auditiva condutiva (Guizar et al 1978, Zankl e Zang 1979, Strisciuglio et al 1986, Oliveira et al 1989), o processo inicial de delineamento dessa e a sobreposição clínica com o EOAV acabam dificultando a definição diagnóstica. Embora os Casos 42 e 43 (Figura 62; III-2) tenham história familial positiva (parentes distantes) para anomalia auricular e apêndice pré-auricular, não se pode afirmar se estes sinais clínicos estão relacionados com o quadro ou se representam achados casuais. Comprometimento mais grave de face, alteração ocular e envolvimento de outros sistemas, além da atresia aural, microtia e perda auditiva, foram observados nos Casos 44, 45, 46 e 47 (Tabela 11; Figuras 63, 64, 65 e 66, respectivamente), o que torna este conjunto de achados clínicos mais compatível com o diagnóstico de EOAV. Coloboma de pálpebra superior, dermóide epibulbar, microftalmia, cardiopatia congênita, agenesia pulmonar e defeito de coluna cervical, sinais observados nesses indivíduos são achados comuns no EOAV. Perda auditiva condutiva (Caso 46 e 47) e sensorioneural (Casos 44, 45 e 47) fazem parte do EOAV. Apêndices pré-auriculares em parentes distantes do Caso 47, possivelmente, representem achados fortuitos. Diante do acima exposto em relação aos Casos 30 a 47, ficou evidente a dificuldade de se definir entre síndrome da atresia aural, 
microtia e deficiência auditiva condutiva e o EOAV. Isto se deve, não somente por esses indivíduos apresentarem envolvimento dos mesmos campos de desenvolvimento, mas, também, pela acentuada similaridade clínica entre as duas condições consideradas como possibilidades diagnósticas. Fatores como: fase inicial de delineamento da síndrome da atresia aural, microtia e deficiência auditiva condutiva; acentuada variabilidade fenotípica com manifestações faciais leves até grave comprometimento craniofacial; envolvimento de outros sistemas no EOAV e acometimento unilateral em $70 \%$ a $90 \%$ dos indivíduos relatados com o EOAV, foram considerados para o estabelecimento diagnóstico. É possível que os Casos 30 a 47 representem um espectro contínuo da síndrome da atresia aural, microtia e deficiência auditiva condutiva ou do EOAV, ou, ainda, que esses quadros representem, na verdade, uma única condição. Adição de novos relatos e, principalmente, o refinamento dos critérios diagnósticos, poderão clarear esses aspectos.

O diagnóstico estabelecido para os Casos 48, 49 e 50 (Tabela 11; Figuras 67, 70 e 72, respectivamente), da presente casuística, foi síndrome de Treacher-Collins (OMIM 154500), condição clinicamente variável, tanto inter quanto intrafamilial e caracterizada por anomalias craniofaciais, geralmente bilaterais e simétricas. Achados importantes nesse quadro são hipoplasia do arco zigomático, fendas palpebrais oblíquas para baixo, coloboma de pálpebra inferior, fissura de palato, hipoplasia mandibular, anomalias auriculares e deficiência auditiva condutiva. Comprometimento facial grave, incluindo seqüência de Robin, até forma leve, com hipoplasia do arco zigomático ou fendas palpebrais oblíquas para baixo, foram descritas (Gorlin et al 2001, Marszalek et al 2002). Deficiência auditiva condutiva está presente em cerca de 50\% dos indivíduos com essa síndrome (Gorlin et al 2001, Marres 2002) e perda auditiva sensorioneural e mista são incomuns, possivelmente pela raridade de anomalias de orelha interna nesses indivíduos. Etiologicamente é heterogênea, com evidência de fatores genéticos e ambientais. Mutações no gene TCOF1 foram identificadas como responsáveis pela síndrome de Treacher-Collins (Balestrazzi et al 1983, Lungarotti et al 1987, Arn et al 1993, Richieri-Costa et al 1993, Splendore et al 2000, Teber et al 2004). Os Casos 48, 49 e 50 apresentaram sinais faciais característicos da síndrome de Treacher-Collins. Recorrência familial, sugerindo modelo de herança autossômica dominante, foi observada nos Casos 48 e 49 (Figuras 69 e 71, respectivamente). Consangüinidade parental do Caso 48 é, muito provavelmente, fortuita. Expressividade clínica variável, 
com forma leve do quadro, foi referida em indivíduos de três gerações da família do Caso 49 (Figura 71). Embora clinicamente compatíveis com o diagnóstico de síndrome de Treacher-Collins, os casos em questão foram diferenciados de outros quadros que envolvem disostose mandibulofacial, principalmente o EOAV (OMIM 164210) e a síndrome de Nager (OMIM-154400). O primeiro quadro foi descartado pela ausência de microssomia hemifacial, dermóide epibulbar e anomalias músculo-esqueléticas e, o segundo, pela ausência de anomalias de primeiro raio.

Os Casos 51 e 52 (Tabela 11; Figuras 73 e 74, respectivamente), da presente casuística, apresentaram sinais clínicos compatíveis com o diagnóstico de síndrome de Nager (OMIM-154400), condição caracterizada por disostose mandibulofacial e anomalias de membros, particularmente agenesia de rádio, sinostose rádio-ulnar e hipoplasia ou agenesia de polegares. Penetrância incompleta do gene, expressividade clínica variável e heterogeneidade genética, com formas autossômicas dominante e recessiva, têm sido observadas na síndrome de Nager (McDonald e Gorski, 1993). O gene ZFP37, mapeado no cromossomo 9p32, foi proposto como gene candidato para esta síndrome. Perda auditiva condutiva, freqüentemente congênita e moderada, ocorre em $85 \%$ dos indivíduos com essa condição e tem sido atribuída às malformações de orelha externa, de canal auditivo externo e ossiculares (Halal et al 1983, Meyerson e Nisbet 1987, Hall 1989, Gorlin et al 2001). Apesar da perda auditiva sensorioneural não estar associada à síndrome de Nager, perda auditiva mista foi referida ocasionalmente (Danziger et al 1990). Os Casos 51 e 52, da presente casuística, apresentaram achados clínicos, craniofaciais e de membros, característicos da síndrome de Nager. Grau de acometimento mais acentuado foi observado no Caso 52, que apresentou seqüência de Robin e agenesia de polegares. Em relação à história familial, mesmo considerando a expressividade clínica variável da síndrome de Nager, não se pode afirmar que a presença de discreta micrognatia, na genitora do Caso 51, represente uma forma leve da síndrome. Idade paterna avançada, no Caso 52, pode estar relacionada com mutação nova dominante. Esta relação foi previamente sugerida por alguns autores (Marden et al 1964, Lowry 1977). Apesar de clinicamente compatíveis com o diagnóstico da síndrome de Nager, os Casos 51 e 52 foram diferenciados de outras condições que envolvem disostose mandibulofacial e alterações de membros, entre elas, a síndrome de Treacher-Collins (OMIM 154500), a síndrome de GenéeWiedmann (OMIM 263750) e o espectro oculoauriculovertebral (OMIM 164210). 
Apesar da similaridade facial, a ausência de anomalias pré-axiais de membros, excluiu a síndrome de Treacher-Collins. Já, a exclusão da síndrome de Genée-Wiedemann se faz pelo envolvimento, nessa, de anomalias pós-axial em membros superiores e inferiores. O espectro oculoauriculovertebral, embora, ocasionalmente, apresente defeitos radiais, pode ser diferenciado pelo envolvimento unilateral de crânio e face.

Os Casos 53 e 54 (Tabela 11; Figuras 75 e 76, respectivamente) apresentam, em comum, anomalia da estrutura auricular, fístula branquial e deficiência auditiva, sinais estes pertencentes ao espectro clínico das síndromes autossômicas dominantes branquiogênicas, especialmente as síndromes de BOR (OMIM 113650) e de BO (OMIM 602588). As manifestações clínicas dessas síndromes variam significantemente de uma família para outra. Relatos de indivíduos com a síndrome BOR mostram larga variabilidade intra e interfamilial (Kumar et al, 2000). Deficiência auditiva, condutiva, sensorioneural ou mista, considerada como a característica mais importante desse quadro, ocorre em 93\% dos indivíduos. Anomalias renais variam de leve hipoplasia a aplasia renal bilateral (Kalatzis e Petit 1999). Ao lado das clássicas anomalias de orelha, rim e arco branquial, estenose do ducto lacrimal, paralisia facial e, ainda, alterações de outros sistemas têm sido descritas (Ruf et al 2003). Quando a expressão fenotípica é limitada às anomalias branquiais, fístula pré-auricular e perda auditiva, sem anomalia renal, o quadro tem sido referido como síndrome branquio-oto (BO - OMIM 120502). Revisão de literatura tem mostrado discussão sobre a possibilidade dessas condições serem alélicas ou clinicamente distintas (Kumar et al 1998). Mutações no gene $E Y A 1$ foram encontradas tanto em famílias com o fenótipo da síndrome BOR quanto em famílias com o da síndrome BO (Rickard et al 2000; Chang et al 2004). Estudos recentes de Chang et al (2004) em 16 famílias com o fenótipo BOR, decorrentes de mutação no gene $E Y A 1$, possibilitaram o refinamento do critério diagnóstico para a síndrome de BOR. Esses autores propuseram que esse diagnóstico seja estabelecido na presença de: pelo menos três achados maiores; ou dois achados maiores e pelo menos dois menores; ou pelo menos um achado maior e um parente de primeiro grau afetado com o quadro. Foram considerados achados maiores: anomalias branquiais, deficiência auditiva, fístula pré-auricular e anomalias renais e, achados menores: anomalias de orelha externa, média e/ou interna; apêndices pré-auriculares, assimetria facial e anomalias de palato. As manifestações clínicas dos Casos 53 e 54 se incluem no fenótipo BOR. Com base no critério diagnóstico proposto por Chang et al 
(2004) observa-se que o Caso 53 apresenta três sinais maiores (anomalias branquiais, deficiência auditiva e fístula pré-auricular) e, o Caso 54, dois sinais maiores (anomalia branquial e deficiência auditiva) e dois menores (anomalia auricular, apêndice préauricular) o que os enquadram no diagnóstico de síndrome BOR, mesmo na ausência de anomalia renal. Atraso neuropsicomotor observado nesses casos não é comum na síndrome BOR. Em relação ao diagnóstico diferencial, síndromes como a oto-faciocervical (OMIM 166780) e a branquio-oculo-facial (BOF) (OMIM 113620) foram consideradas. Ausência de anomalia de escápula e anomalias vertebrais nos Casos 53 e 54, descarta a síndrome oto-facio-cervical. Sinais clínicos como aplasia de pele e anomalias oculares, característicos da síndrome branquio-oculo-facial e não observados nos casos em questão, exclui esta possibilidade.

O Caso 55 (Tabela 11; Figura 77), outro indivíduo do grupo com deficiência auditiva e envolvimento de orelha externa, apresentou um conjunto de sinais clínicos que não se enquadraram nas síndromes que cursam com perda auditiva, descritas até o momento (Gorlin et al 1995, OMIM 2006). Considerando o fenótipo craniofacial desse indivíduo, embora acentuada sobreposição clínica com o EOAV seja observada, o padrão simétrico de envolvimento das orelhas é discordante do observado nessa condição. Outros sinais, presentes no Caso 55, como cardiopatia e atraso no desenvolvimento neuropsicomotor são citados no EOAV; porém, manchas hipocrômicas (tronco e membros) não foram, até o momento, referidas em indivíduos com este quadro. Por outro lado, várias síndromes cursam com esta anomalia de tegumento e deficiência auditiva; porém, as manifestações presentes no indivíduo em questão não preenchem os critérios de inclusão nessas condições. 


\subsubsection{Grupo 6: Indivíduos com deficiência auditiva e envolvimento de tegumento (Casos 56 a 80)}

Nesse grupo, foram incluídos 24 indivíduos com deficiência auditiva e anomalias de tegumento. Síndrome de Waardenburg foi considerada como diagnóstico de 22 indivíduos (Casos 56 a 77). Desses, 6 apresentaram sinais clínicos compatíveis com a síndrome de Waardenburg do tipo I (Casos 56 a 61), 15 com a do tipo II (Casos 62 a 76) e 1 com a do tipo III (caso 77). Quadro de piebaldismo foi o diagnóstico para os Casos 78 e 79. Todos os casos desse grupo apresentaram deficiência auditiva sensorioneural. Os dados referentes a esses indivíduos foram apresentados na Tabela 12. 
TABELA 12: Dados dos indivíduos com deficiência auditiva e envolvimento de tegumento

\begin{tabular}{|c|c|c|c|c|c|c|}
\hline Indivíduo & Sexo & Idade & Sinais clínicos & $\begin{array}{l}\text { Dados gestacionais e perinatais/ } \\
\text { antecedentes pessoais e familiais }\end{array}$ & $\begin{array}{l}\text { Exames complementares e } \\
\text { caracterização da DA }\end{array}$ & $\begin{array}{l}\text { Hipótese diagnóstica } \\
\text { (modelo de herança) }\end{array}$ \\
\hline 56 & $\mathrm{~F}$ & $11 \mathrm{a} 9 \mathrm{~m}$ & $\begin{array}{l}\text { Mecha branca de cabelos na região } \\
\text { frontal; sobrancelhase cílios parcialmente } \\
\text { brancos; sinofre; hipertelorismo ocular; } \\
\text { dystopia canthorum; hipocromia de íris; } \\
\text { nariz pequeno; base nasal larga; hipoplasia } \\
\text { alar; deficiência auditiva; hipopigmentação } \\
\text { de pele }\end{array}$ & $\begin{array}{l}\text { IMC: } 25 \mathrm{a} \text { / IPC: ? } \text { G2P2A0 } \\
\text { Sem intercorrências gestacionais. } \\
\text { Parto normal; gestação a termo. } \\
\mathrm{PN}=2.850 \mathrm{~g}(\mathrm{p}=10) \\
\mathrm{EN}=49 \mathrm{~cm}(25<\mathrm{p}<50) \\
\text { Sem intercorrências perinatais. } \\
\text { Avó materna e } 1 \text { tia materna, em } 2^{\circ} \text { grau, } \\
\text { com cabelos grisalhos precocemente e } \\
\text { heterocromia de íris; mãe e } 1 \text { prima com } \\
\text { sinofre, dystopia canthorum, hipoplasia } \\
\text { alar e hipopigmentação de pele; } 2 \text { tios e } 1 \\
\text { primo maternos com cabelos grisalhos } \\
\text { precocemente, heterocromia de íris, DA e } \\
\text { hipopigmentação de pele; } 1 \text { tio e } 1 \text { primo } \\
\text { maternos com mecha branca de cabelos, } \\
\text { hipocromia de íris e hipopigmentação de } \\
\text { pele; } 2 \text { primos maternos com heterocromia } \\
\text { de íris e hipopigmentação de pele. }\end{array}$ & $\begin{array}{l}\text { Avaliação audiológica:DA } \\
\text { sensorioneural profunda bilateral }\end{array}$ & $\begin{array}{c}\text { Síndrome de Waardenburg } \\
\text { tipo I } \\
\text { (HAD) }\end{array}$ \\
\hline 57 & M & $8 \mathrm{a} 6 \mathrm{~m}$ & $\begin{array}{l}\text { Mecha branca de cabelos na região frontal } \\
\text { (atualmente, alguns fios brancos); sinofre; } \\
\text { hipertelorismo ocular; dystopia canthorum; } \\
\text { hipocromia de íris; base nasal alta e larga; } \\
\text { hipoplasia de asa nasal; nevus na face } D \text {; } \\
\text { deficiência auditiva; hipopigmentação de } \\
\text { pele em membros superiores }\end{array}$ & $\begin{array}{l}\text { IMC: } 35 \mathrm{a} / \text { IPC: } 46 \mathrm{a} \quad \text { G1P1A0 } \\
\text { Sem intercorrências gestacionais. } \\
\text { Inseminação artificial (doador } \\
\text { desconhecido). } \\
\text { Parto cesáreo; gestação a termo. } \\
\mathrm{PN}=2.750 \mathrm{~g}(3<\mathrm{p}<10) \\
\mathrm{EN}=50 \mathrm{~cm}(\mathrm{p}=25) \\
\text { Sem intercorrências perinatais. } \\
\text { Aos } 4 \text { anos de idade, realizou correção } \\
\text { cirúrgica do hipertelorismo ocular. } \\
1 \text { tio materno, em } 2^{\circ} \text { grau, com DA. } \\
\text { Aos } 8 \mathrm{a} \text { 6m: DICI }=3.8 \mathrm{~cm}(\mathrm{p}>97) \\
\text { DICE }=9.6 \mathrm{~cm}(\mathrm{p}>97)\end{array}$ & $\begin{array}{l}\text { Avaliação audiológica:DA } \\
\text { sensorioneural moderada à D e } \\
\text { profunda à E }\end{array}$ & $\begin{array}{c}\text { Síndrome de Waardenburg } \\
\text { tipo I } \\
\text { (HAD) }\end{array}$ \\
\hline
\end{tabular}


Continuação TABELA 12: Dados dos indivíduos com deficiência auditiva e envolvimento de tegumento

\begin{tabular}{|c|c|c|c|c|c|c|}
\hline Indivíduo & Sexo & Idade & Sinais clínicos & $\begin{array}{l}\text { Dados gestacionais e perinatais/ } \\
\text { antecedentes pessoais e familiais }\end{array}$ & $\begin{array}{l}\text { Exames complementares e } \\
\text { caracterização da DA }\end{array}$ & $\begin{array}{l}\text { Hipótese diagnóstica } \\
\text { (modelo de herança) }\end{array}$ \\
\hline 58 & $\mathrm{~F}$ & 2a $10 \mathrm{~m}$ & $\begin{array}{l}\text { Fronte ampla; sinofre; hipertelorismo ocular; } \\
\text { dystopia canthorum; heterocromia de íris; } \\
\text { base e ponte nasal achatadas; hipoplasia asa } \\
\text { nasal; hipoplasia filtro;deficiência auditiva }\end{array}$ & $\begin{array}{l}\text { IMC: } 15 \mathrm{a} \text { / IPC: } 21 \mathrm{a} \text { G1P1A0 } \\
\text { Infecção do trato urinário no } 3^{\circ} \text { mês } \\
\text { gestacional. Uso de medicamento } \\
\text { intravenoso. } \\
\text { Parto normal; gestação de } 8 \text { meses. } \\
\text { PN= } 2.760 \mathrm{~g}(10<\mathrm{p}<25) \\
\mathrm{EN}=48 \mathrm{~cm}(25<\mathrm{p}<50) \\
\text { Sem intercorrências perinatais. } \\
\text { Pai com mecha branca de cabelos, mancha } \\
\text { hipocrômica de pele, sinofre e DA; } 1 \text { tio } \\
\text { paterno, em } 2^{\circ} \text { grau, com mecha branca de } \\
\text { cabelos,hipopigmentação de pele, sinofre, } \\
\text { heterocromia de íris e DA; } 1 \text { tio, } 1 \text { tia e } 1 \\
\text { prima paterna, em } 2^{\circ} \text { grau, com } \\
\text { heterocromia de íris e DA; } 1 \text { tia paterna, } \\
\text { em } 2^{\circ} \text { grau, com mecha branca de cabelos } \\
\text { e DA; } 1 \text { prima paterna, em } 3^{\circ} \text { grau e outra } \\
\text { em } 4^{\circ} \text { grau, com mecha branca de cabelos } \\
\text { e heterocromia de íris; } 1 \text { primo paterno, em } \\
3^{\circ} \text { grau, com mecha branca de cabelos e } \\
\text { hipopigmentação de pele; } 1 \text { prima paterna } \\
\text { em } 3^{\circ} \text { grau e } 2 \text { em } 4^{\circ} \text { grau, com mecha } \\
\text { branca de cabelos, sinofre e DA; } 1 \text { tataravô } \\
\text { paterno com heterocromia de íris e DA. }\end{array}$ & $\begin{array}{l}\text { Avaliação audiológica:DA } \\
\text { sensorioneural profunda bilateral }\end{array}$ & $\begin{array}{c}\text { Síndrome de Waardenburg } \\
\text { tipo I } \\
\text { (HAD) }\end{array}$ \\
\hline
\end{tabular}


Continuação TABELA 12: Dados dos indivíduos com deficiência auditiva e envolvimento de tegumento

\begin{tabular}{|c|c|c|c|c|c|c|}
\hline Indivíduo & Sexo & Idade & Sinais clínicos & $\begin{array}{l}\text { Dados gestacionais e perinatais/ } \\
\text { antecedentes pessoais e familiais }\end{array}$ & $\begin{array}{l}\text { Exames complementares e } \\
\text { caracterização da DA }\end{array}$ & $\begin{array}{l}\text { Hipótese diagnóstica } \\
\text { (modelo de herança) }\end{array}$ \\
\hline 59 & $\mathrm{~F}$ & 3a $11 \mathrm{~m}$ & $\begin{array}{l}\text { Sinofre; base nasal alta; hipertelorismo } \\
\text { ocular; dystopia canthorum; obstrução do } \\
\text { canal lacrimal bilateral; heterocromia de } \\
\text { íris; hipoplasia da asa nasal; deficiência } \\
\text { auditiva; hipopigmentaçaode pele na mão } \\
\text { D e região abdominal }\end{array}$ & $\begin{array}{l}\text { IMC: } 25 \mathrm{a} / \text { IPC: } 27 \mathrm{a} \\
\text { Sem intercorrências gestacionais } \\
\text { relevantes. } \\
\text { Parto cesáreo; gestação a termo. } \\
\mathrm{PN}=4.050 \mathrm{~g}(\mathrm{p}=90) \\
\mathrm{EN}=49 \mathrm{~cm}(\mathrm{p}=25) \\
\text { Aos } 2 \text { a de idade, teve infecção intestinal e } \\
1 \text { episódio convulsivo por febre. } \\
\text { Caso isolado. }\end{array}$ & $\begin{array}{l}\text { Cariótipo: } 46, \mathrm{XX} \\
\text { Avaliação audiológica: DA } \\
\text { sensorioneural profunda bilateral }\end{array}$ & $\begin{array}{c}\text { Síndrome de Waardenburg } \\
\text { tipo I } \\
\text { (HAD) }\end{array}$ \\
\hline 60 & $\mathrm{~F}$ & $3 \mathrm{a} 2 \mathrm{~m}$ & $\begin{array}{l}\text { Mecha branca de cabelos na região } \\
\text { frontal; sinofre; dystopia canthorum; } \\
\text { hipertelorismo ocular; heterocromia de íris; } \\
\text { ponte nasal alta; hipoplasia de asa nasal; } \\
\text { deficiência auditiva; hipopigmentação de } \\
\text { pele na mão E e membro inferior } \mathbf{E}\end{array}$ & $\begin{array}{l}\text { IMC: } 19 \mathrm{a} / \text { IPC: } 30 \mathrm{a} \text { G1P1A0 } \\
\text { Sem intercorrências gestacionais. } \\
\text { Parto normal; gestação a termo. } \\
\mathrm{PN}=3.080 \mathrm{~g}(\mathrm{p}=25) \\
\mathrm{EN}=47 \mathrm{~cm}(3<\mathrm{p}<10) \\
\text { Sem intercorrências perinatais. } \\
\text { Avô materno com cabelos grisalhos } \\
\text { precocemente e sinofre; mãe e } 1 \text { primo } \\
\text { materno com sinofre, dystopia } \\
\text { canthorume hipoplasia da asa nasal; } 2 \text { tios } \\
\text { maternos com cabelos grisalhos } \\
\text { precocemente e sinofre; } 1 \text { tia e } 1 \text { prima } \\
\text { materna com sinofre e heterocromia de } \\
\text { íris. }\end{array}$ & $\begin{array}{l}\text { Cariótipo: } 46, \mathrm{XX} \\
\text { Avaliação audiológica:DA } \\
\text { sensorioneural profunda bilateral }\end{array}$ & $\begin{array}{c}\text { Síndrome de Waardenburg } \\
\text { tipo I } \\
\text { (HAD) }\end{array}$ \\
\hline
\end{tabular}


Continuação TABELA 12: Dados dos indivíduos com deficiência auditiva e envolvimento de tegumento

\begin{tabular}{|c|c|c|c|c|c|c|}
\hline Indivíduo & Sexo & Idade & Sinais clínicos & $\begin{array}{l}\text { Dados gestacionais e perinatais/ } \\
\text { antecedentes pessoais e familiais }\end{array}$ & $\begin{array}{l}\text { Exames complementares e } \\
\text { caracterização da DA }\end{array}$ & $\begin{array}{l}\text { Hipótese diagnóstica } \\
\text { (modelo de herança) }\end{array}$ \\
\hline 61 & M & $15 \mathrm{a} 10 \mathrm{~m}$ & $\begin{array}{l}\text { Mecha branca de cabelos na região } \\
\text { frontal; sinofre; hipertelorismo ocular; } \\
\text { dystopia canthorum; hipocromia de íris à } \\
\text { E; ponte nasal alta; hipoplasia de asa nasal; } \\
\text { deficiência auditiva }\end{array}$ & $\begin{array}{l}\text { IMC: } 18 \mathrm{a} \text { / IPC: } 21 \mathrm{a} \quad \text { G2P2A0 } \\
\text { Aos } 3 \mathrm{~m} \text {, apresentou exantema, febre e } \\
\text { dores articulares, durante } 2 \text { dias. Não } \\
\text { consultou o médico; não realizou } \\
\text { sorologia. } \\
\text { Parto fórceps; gestação a termo. } \\
\mathrm{PN}=3.800 \mathrm{~g}(3<\mathrm{p}<10) \\
\mathrm{EN}=50 \mathrm{~cm}(25<\mathrm{p}<50) \\
\text { Choro demorado. Cianose. } \\
\text { Irmã com telecanto, sinofre e hipocromia } \\
\text { de pele; mãe com mecha branca de cabelos } \\
\text { na região frontal, sinofre, telecanto e } \\
\text { hipoplasia de asa nasal; } 1 \text { tio materno com } \\
\text { cabelos grisalhos precocemente, mecha } \\
\text { branca de cabelos; sinofre, telecanto e } \\
\text { hipocromia de íris; } 1 \text { primo materno com } \\
\text { hipocromia de íris; avó materna com } \\
\text { dystopia canthorum; vários outros } \\
\text { parentes maternos com sinais clínicos da } \\
\text { mesma condição. }\end{array}$ & $\begin{array}{l}\text { Avaliação audiológica:DA } \\
\text { sensorioneural profunda bilateral }\end{array}$ & $\begin{array}{c}\text { Síndrome de Waardenburg } \\
\text { tipo I } \\
\text { (HAD) }\end{array}$ \\
\hline 62 & $\mathrm{~F}$ & $8 \mathrm{a} 2 \mathrm{~m}$ & $\begin{array}{l}\text { Mecha mais clara de cabelos na região } \\
\text { frontal; aparente hipertelorismo ocular; } \\
\text { deficiência auditiva }\end{array}$ & $\begin{array}{l}\text { IMC: } 36 \mathrm{a} \text { / IPC: } 31 \mathrm{a} 2 \mathrm{P} 1 \mathrm{~A} 1 \\
\text { Sem intercorrências gestacionais. } \\
\text { Parto cesáreo; gestação a termo. } \\
\mathrm{PN}=2.750 \mathrm{~g}(3<\mathrm{p}<10) \quad \text { EN }=\text { ? } \\
\text { Sem intercorrências perinatais. } \\
\text { Bisavô materno com DA; avô materno com } \\
\text { DA; } 1 \text { tio materno, em } 2^{\circ} \text { grau, com DA; } \\
\text { avó materna com hipopigmentação de } \\
\text { pele; } 2 \text { tios maternos, em } 2^{\circ} \text { grau, com } \\
\text { cabelos brancos precocemente; mãe com } \\
\text { DA e cabelos grisalhos precocemente; } 2 \\
\text { tias maternas com DA; } 1 \text { prima materna } \\
\text { com DA. }\end{array}$ & $\begin{array}{l}\text { Cariótipo: } 46, \mathrm{XX} \\
\text { Avaliação audiológica: DA } \\
\text { sensorioneural profunda bilateral }\end{array}$ & $\begin{array}{c}\text { Síndrome de Waardenburg } \\
\text { tipo II } \\
\text { (HAD) }\end{array}$ \\
\hline
\end{tabular}


Continuação TABELA 12: Dados dos indivíduos com deficiência auditiva e envolvimento de tegumento

\begin{tabular}{|c|c|c|c|c|c|c|}
\hline Indivíduo & Sexo & Idade & Sinais clínicos & $\begin{array}{l}\text { Dados gestacionais e perinatais/ } \\
\text { antecedentes pessoais e familiais }\end{array}$ & $\begin{array}{l}\text { Exames complementares e } \\
\text { caracterização da DA }\end{array}$ & $\begin{array}{l}\text { Hipótese diagnóstica } \\
\text { (modelo de herança) }\end{array}$ \\
\hline 63 & M & $13 \mathrm{a}$ & $\begin{array}{l}\text { Hipertelorismo ocular; deficiência auditiva; } \\
\text { sindactilia do } 2^{\circ} \text { e } 3^{\circ} \text { artelhos bilateral }\end{array}$ & $\begin{array}{l}\text { IMC: 20a / IPC: } 23 \text { a G3P4A0 } \\
\text { Sem intercorrências gestacionais. } \\
\text { Parto cesáreo; gestação a termo. } \\
\text { PN=? EN=? } \\
\text { Sem intercorrências neonatais. } \\
\text { Avó materna com DA e cabelos brancos } \\
\text { precocemente; } 1 \text { tio materno, em } 2^{\circ} \text { grau, } \\
\text { com DA; mãe e } 2 \text { tios maternos com } \\
\text { cabelos brancos precocemente e sinofre; } 1 \\
\text { tia materna com DA. Irmãos gêmeos, } 1 \\
\text { com DA e outro com cabelos grisalhos } \\
\text { precocemente e } 1 \text { outro irmão também } \\
\text { com cabelos grisalhos precocemente. } \\
\text { Aos } 13 \text { a idade: DICI }=3.6 \mathrm{~cm}(\mathrm{p}=97) \\
\quad \text { DICE }=10.2 \mathrm{~cm}(\mathrm{p}>97)\end{array}$ & $\begin{array}{l}\text { Cariótipo: } 46, X Y \\
\text { Avaliação audiológica:DA } \\
\text { sensorioneural leve à D }\end{array}$ & $\begin{array}{l}\text { Sínd. de Waardenburg } \\
\text { tipo II } \\
\text { (HAD) }\end{array}$ \\
\hline 64 & M & $5 \mathrm{a} 6 \mathrm{~m}$ & Hipocromia de íris; deficiência auditiva & $\begin{array}{l}\text { IMC: 20a / IPC: } 22 \mathrm{a} \quad \text { G1P1A0 } \\
\text { Sem intercorrências gestacionais. } \\
\text { Parto normal; gestação a termo. } \\
\mathrm{PN}=2.970 \mathrm{~g}(\mathrm{p}=10) \\
\mathrm{EN}=49.5 \mathrm{~cm}(10<\mathrm{p}<25) \\
\text { Pai, } 1 \text { tio paterno, em } 2^{\circ} \text { grau, e } 1 \text { primo } \\
\text { paterno com hipocromia de íris; } 1 \text { tia e } 1 \\
\text { primo paterno com mecha branca de } \\
\text { cabelos. }\end{array}$ & $\begin{array}{l}\text { Cariótipo: } 46, \mathrm{XY} \\
\text { Avaliação audiológica:DA } \\
\text { sensorioneural severa bilateral }\end{array}$ & $\begin{array}{c}\text { Síndrome de Waardenburg } \\
\text { tipo II } \\
\text { (HAD) }\end{array}$ \\
\hline
\end{tabular}


Continuação TABELA 12: Dados dos indivíduos com deficiência auditiva e envolvimento de tegumento

\begin{tabular}{|c|c|c|c|c|c|c|}
\hline Indivíduo & Sexo & Idade & Sinais clínicos & $\begin{array}{l}\text { Dados gestacionais e perinatais/ } \\
\text { antecedentes pessoais e familiais }\end{array}$ & $\begin{array}{l}\text { Exames complementares e } \\
\text { caracterização da DA }\end{array}$ & $\begin{array}{l}\text { Hipótese diagnóstica } \\
\text { (modelo de herança) }\end{array}$ \\
\hline 65 & $\mathrm{~F}$ & & $\begin{array}{l}\text { Base nasal alta; narinas pequenas; } \\
\text { hipocromia de íris; deficiência auditiva; } \\
\text { atresia de esôfago; convulsões; ADNM leve }\end{array}$ & $\begin{array}{l}\text { IMC: } 23 \mathrm{a} / \mathrm{IPC}: 29 \mathrm{a} \quad \mathrm{G} 2 \mathrm{P} 2 \mathrm{~A} 0 \\
\text { Sem intercorrências gestacionais. } \\
\text { Parto cesáreo; gestação a termo. } \\
\mathrm{PN}=2.630 \mathrm{~g}(3<\mathrm{p}<10) \\
\mathrm{EN}=45 \mathrm{~cm}(\mathrm{p}<3) \\
\text { Aos } 15 \text { dias de vida, apresentou otite. } \\
\text { Caso isolado. }\end{array}$ & $\begin{array}{l}\text { Análise molecular: negativo para } \\
\text { mutções no gene PAX3 } \\
\text { Avaliação audiológica:DA } \\
\text { sensorioneural profunda bilateral }\end{array}$ & $\begin{array}{c}\text { Síndrome de Waardenburg } \\
\text { tipo II } \\
\text { (HAD) }\end{array}$ \\
\hline 66 & $\mathrm{~F}$ & $4 \mathrm{a} 4 \mathrm{~m}$ & $\begin{array}{l}\text { Sinofre; base e ponte nasal altos e largos; } \\
\text { hipocromia de íris bilateral, deficiência } \\
\text { auditiva }\end{array}$ & $\begin{array}{l}\text { IMC: } 19 \mathrm{a} / \text { IPC: } 25 \mathrm{a} \quad \text { G3P2A1 } \\
\text { Sem intercorrências gestacionais. } \\
\text { Parto cesáreo; gestação a termo. } \\
\mathrm{PN}=3.170 \mathrm{~g}(25<\mathrm{p}<50) \\
\mathrm{EN}=50 \mathrm{~cm}(\mathrm{p}=50) \\
\text { Avô paterno com cabelos grisalhos } \\
\text { precocemente; pai e } 2 \text { tios paternos com } \\
\text { sinofre; } 1 \text { tio paterno, em } 2^{\circ} \text { grau, com DA; } \\
\text { bisavó paterna com hipocromia de íris. }\end{array}$ & $\begin{array}{l}\text { Avaliação audiológica:DA } \\
\text { sensorioneural profunda bilateral }\end{array}$ & $\begin{array}{c}\text { Síndrome de Waardenburg } \\
\text { tipo II } \\
\text { (HAD) }\end{array}$ \\
\hline 67 & $\mathrm{~F}$ & $22 \mathrm{a}$ & $\begin{array}{l}\text { Mecha branca de cabelos na região } \\
\text { frontal; heterocromia de íris; deficiência } \\
\text { auditiva }\end{array}$ & $\begin{array}{l}\text { IMC: } 16 \mathrm{a} / \mathrm{IPC}: 24 \mathrm{a} \\
\text { Sem intercorrências gestacionais. } \\
\text { Parto normal; gestação a termo. } \\
\mathrm{PN}=2.030 \mathrm{~g}(\mathrm{p}<3) \\
\mathrm{EN}=42 \mathrm{~cm}(\mathrm{p}<3) \\
\text { Sem intercorrências perinatais. } \\
\text { Avó materna com heterocromia de íris e } \\
\text { DA; mãe com cabelos grisalhos } \\
\text { precocemente e DA; } 1 \text { tia materna e } 2 \\
\text { primas com heterocromia de íris e DA; } 5 \\
\text { irmãs com DA; } 1 \text { irmão com mecha branca } \\
\text { de cabelos e } 1 \text { irmão com heterocromia de } \\
\text { íris. }\end{array}$ & $\begin{array}{l}\text { Cariótipo: } 46, X X \\
\text { Avaliação audiológica:DA } \\
\text { sensorioneural leve à D e profunda à } \\
\text { E }\end{array}$ & $\begin{array}{c}\text { Síndrome de Waardenburg } \\
\text { tipo II } \\
\text { (HAD) }\end{array}$ \\
\hline
\end{tabular}


Continuação TABELA 12: Dados dos indivíduos com deficiência auditiva e envolvimento de tegumento

\begin{tabular}{|c|c|c|c|c|c|c|}
\hline Indivíduo & Sexo & Idade & Sinais clínicos & $\begin{array}{l}\text { Dados gestacionais e perinatais/ } \\
\text { antecedentes pessoais e familiais }\end{array}$ & $\begin{array}{l}\text { Exames complementares e } \\
\text { caracterização da DA }\end{array}$ & $\begin{array}{l}\text { Hipótese diagnóstica } \\
\text { (modelo de herança) }\end{array}$ \\
\hline $68 *$ & M & $8 \mathrm{a} 4 \mathrm{~m}$ & $\begin{array}{l}\text { Crânio grande; fronte ampla; sinofre; } \\
\text { heterocromia de íris; deficiência auditiva; } \\
\text { leve ADNM }\end{array}$ & $\begin{array}{l}\text { IMC: } 19 \mathrm{a} / \text { IPC: } 28 \mathrm{a} \quad \text { G1P1A0 } \\
\text { Sem intercorrências gestacionais } \\
\text { relevantes. } \\
\text { Parto cesáreo; gestação a termo. } \\
\mathrm{PN}=3.350 \mathrm{~g}(25<\mathrm{p}<50) \\
\mathrm{EN}=\text { ? } \\
\text { Sem intercorrências perinatais. } \\
\text { Aos } 8 \mathrm{a} 4 \mathrm{~m}: \mathrm{PC}=54.5 \mathrm{~cm}(50<\mathrm{p}<75) \\
\text { Caso isolado. }\end{array}$ & $\begin{array}{l}\text { Avaliação audiológica:DA } \\
\text { sensorioneural profunda à D e } \\
\text { moderada à E }\end{array}$ & $\begin{array}{c}\text { Síndrome de Waardenburg } \\
\text { tipo II } \\
\text { (HAD) }\end{array}$ \\
\hline 69 & $\mathrm{~F}$ & $7 \mathrm{a} 3 \mathrm{~m}$ & $\begin{array}{l}\text { Mecha mais clara de cabelos na região } \\
\text { frontal; hetrocromia de íris; deficiência } \\
\text { auditiva; ADNM leve }\end{array}$ & $\begin{array}{l}\text { IMC: } 27 \mathrm{a} / \text { IPC: } 32 \mathrm{a} \quad \text { G4P4A0 } \\
\text { Sem intercorrências gestacionais. } \\
\text { Parto cesareo; gestação a termo. } \\
\text { PN=4.500g (p }>97) \\
\text { EN=? } \\
\text { Sem intercorrências perinatais. } \\
\text { Caso isolado. }\end{array}$ & $\begin{array}{l}\text { Tomografia computadorizada crânio- } \\
\text { encefálica: normal } \\
\text { Avaliação audiológica:DA } \\
\text { sensorioneural profunda bilateral }\end{array}$ & $\begin{array}{l}\text { Síndrome de Waardenburg } \\
\text { tipo II } \\
\text { (HAD) }\end{array}$ \\
\hline 70 & M & $7 \mathrm{a} 10 \mathrm{~m}$ & $\begin{array}{l}\text { Hipertelorismoocular; heterocromiade íris; } \\
\text { base nasal larga e alta; hipoplasia alar; } \\
\text { deficiência auditiva ADNM leve }\end{array}$ & $\begin{array}{l}\text { IMC: } 28 \mathrm{a} / \mathrm{IPC}: 30 \mathrm{a} \quad \mathrm{G} 2 \mathrm{P} 2 \mathrm{~A} 0 \\
\text { Sem intercorrências gestacionais. } \\
\text { Parto cesáreo; gestação a termo. } \\
\mathrm{PN}=2.900 \mathrm{~g} \text { (p=10) EN=? } \\
\text { Sem intercorrências perinatais. } \\
\text { Pai com cabelos grisalhos precocemente; } 1 \\
\text { tia paterna, em } 2^{\circ} \text { grau, com heterocromia } \\
\text { de íris. }\end{array}$ & $\begin{array}{l}\text { Cariótipo: } 46, X Y \\
\text { Avaliação audiológica:DA } \\
\text { sensorioneural profunda bilateral }\end{array}$ & $\begin{array}{c}\text { Síndrome de Waardenburg } \\
\text { tipo II } \\
\text { (HAD) }\end{array}$ \\
\hline
\end{tabular}


Continuação TABELA 12: Dados dos indivíduos com deficiência auditiva e envolvimento de tegumento

\begin{tabular}{|c|c|c|c|c|c|c|}
\hline Indivíduo & Sexo & Idade & Sinais clínicos & $\begin{array}{l}\text { Dados gestacionais e perinatais/ } \\
\text { antecedentes pessoais e familiais }\end{array}$ & $\begin{array}{l}\text { Exames complementares e } \\
\text { caracterização da DA }\end{array}$ & $\begin{array}{l}\text { Hipótese diagnóstica } \\
\text { (modelo de herança) }\end{array}$ \\
\hline $71^{*}$ & M & $6 \mathrm{a}$ & Heterocromia de íris;deficiência auditiva & $\begin{array}{l}\text { IMC: } 17 \mathrm{a} / \text { IPC: } 23 \mathrm{a} \\
\text { Sem intercorrências gestacionais. } \\
\text { Parto normal; gestação a termo. } \\
\mathrm{PN}=3.000 \mathrm{~g}(10<\mathrm{p}<25) \\
\mathrm{EN}=52 \mathrm{~cm}(50<\mathrm{p}<75) \\
\text { Sem intercorrências neonatais. } \\
\text { Caso isolado. }\end{array}$ & $\begin{array}{l}\text { Cariótipo: } 46, \mathrm{XY} \\
\text { Avaliação oftalmológica: miopia } \\
\text { bilateral ( } 0.5 \text { di) } \\
\text { Avaliação audiológica:DA } \\
\text { sensorioneural severa bilateral }\end{array}$ & $\begin{array}{c}\text { Síndrome de Waardenburg } \\
\text { tipo II } \\
\text { (HAD) }\end{array}$ \\
\hline 72 & M & $2 \mathrm{a} 7 \mathrm{~m}$ & $\begin{array}{l}\text { Heterocromia de íris; deficiência auditiva; } \\
\text { ADNM leve }\end{array}$ & $\begin{array}{l}\text { IMC: } 22 \mathrm{a} / \mathrm{IPC}: 25 \mathrm{a} \quad \text { G2P2A0 } \\
\text { Sem intercorrências gestacionais } \\
\text { relevantes. } \\
\text { Parto normal; gestação a termo. } \\
\mathrm{PN}=3.760 \mathrm{~g}(50<\mathrm{p}<75) \\
\mathrm{EN}=52 \mathrm{~cm}(50<\mathrm{p}<75) \\
\text { Nasceu com infecção intra-uterina. } \\
\text { Internado } 4 \text { dias. } \\
\text { Caso isolado. }\end{array}$ & $\begin{array}{l}\text { Cariótipo: } 46, \mathrm{XX} \\
\text { Avaliação audiológica:DA } \\
\text { sensorioneural profunda bilateral }\end{array}$ & $\begin{array}{c}\text { Síndrome de Waardenburg } \\
\text { tipo II } \\
\text { (HAD) }\end{array}$ \\
\hline 73 & $\mathrm{~F}$ & $5 \mathrm{a} 4 \mathrm{~m}$ & $\begin{array}{l}\text { Mecha branca de cabelos na região } \\
\text { frontal; estrabismo convergente; } \\
\text { hipocromia de íris; deficiência auditiva; } \\
\text { hipopigmentaçãode pele em tronco, dorso } \\
\text { das mãos e membros inferiores; ADNM } \\
\text { leve }\end{array}$ & $\begin{array}{l}\text { IMC: } 23 \mathrm{a} / \text { IPC: } 20 \mathrm{a} \quad \mathrm{G} 2 \mathrm{P} 2 \mathrm{~A} 0 \\
\text { Sem intercorrências gestacionais } \\
\text { relevantes. } \\
\text { Parto normal; gestação a termo. } \\
\mathrm{PN}=2.840 \mathrm{~g}(\mathrm{p}=10) \\
\mathrm{EN}=48 \mathrm{~cm}(25<\mathrm{p}<50) \\
\text { Nos primeiros dias de vida, apresentou } \\
\text { impetigo. Uso de antibiótico. } \\
\text { Pai com sinofre; bisavô paterno com } \\
\text { heterocromia de íris. }\end{array}$ & $\begin{array}{l}\text { Cariótipo: } 46, \mathrm{XX} \\
\text { Avaliação oftalmológica: miopia e } \\
\text { hipermetropia } \\
\text { Avaliação audiológica:DA } \\
\text { sensorioneural profunda bilateral }\end{array}$ & $\begin{array}{c}\text { Síndrome de Waardenburg } \\
\text { tipo II } \\
\text { (HAD) }\end{array}$ \\
\hline
\end{tabular}


Continuação TABELA 12: Dados dos indivíduos com deficiência auditiva e envolvimento de tegumento

\begin{tabular}{|c|c|c|c|c|c|c|}
\hline Indivíduo & Sexo & Idade & Sinais clínicos & $\begin{array}{l}\text { Dados gestacionais e perinatais/ } \\
\text { antecedentes pessoais e familiais }\end{array}$ & $\begin{array}{l}\text { Exames complementares e } \\
\text { caracterização da DA }\end{array}$ & $\begin{array}{l}\text { Hipótese diagnóstica } \\
\text { (modelo de herança) }\end{array}$ \\
\hline 74 & $\mathrm{~F}$ & $12 \mathrm{a} 4 \mathrm{~m}$ & $\begin{array}{l}\text { Heterocromia de íris; hipermetropia; } \\
\text { hipoplasia alar; deficiência auditiva; } \\
\text { hipopigmentação de pele na região } \\
\text { abdominał clino-camptodactilia } 5^{\circ} \text { dígito } \\
\text { bilateral; leve ADNPM }\end{array}$ & $\begin{array}{l}\text { IMC: } 33 \mathrm{a} / \text { IPC: } 34 \mathrm{a} \quad \mathrm{G} 3 \mathrm{P} 3 \mathrm{~A} 0 \\
\text { Ameaço de parto prematuro aos } 5 \text { meses de } \\
\text { gestação. } \\
\text { Parto normal; gestação a termo. } \\
\mathrm{PN}=2.940 \mathrm{~g}(10<\mathrm{p}<25) \\
\mathrm{EN}=49 \mathrm{~cm}(25<\mathrm{p}<50) \\
\text { Cianose ao nascimento; icterícia. Internada } \\
10 \text { dias. } \\
\text { Cirurgia micro-otológica e adenoidectomia } \\
\text { aos } 15 \text { meses de idade. } \\
1 \text { tio materno, em } 3^{\circ} \text { grau, com DA } \\
\text { profunda. }\end{array}$ & $\begin{array}{l}\text { Avaliação audiológica:DA } \\
\text { sensorioneural profunda bilateral }\end{array}$ & $\begin{array}{c}\text { Síndrome de Waardenburg } \\
\text { tipo II } \\
\text { (HAD) }\end{array}$ \\
\hline 75 & $\mathrm{~F}$ & $7 \mathrm{a} 8 \mathrm{~m}$ & $\begin{array}{l}\text { Mecha de cabelos mais claros na região } \\
\text { parietal D; sinofre; deficiência auditiva; } \\
\text { hipopigmentação de pele em membro } \\
\text { superior e e inferior } \quad \text { D }\end{array}$ & $\begin{array}{l}\text { IMC: } 39 \mathrm{a} / \text { IPC: } 47 \mathrm{a} \quad \text { G6P6A0 } \\
\text { Sem intercorrências gestacionais. } \\
\text { Parto normal; gestação a termo. } \\
\mathrm{PN}=3.090 \mathrm{~g}(\mathrm{p}=25) \\
\mathrm{EN}=\text { ? } \\
\text { Sem intercorrências perinatais. } \\
\text { Caso isolado. }\end{array}$ & $\begin{array}{l}\text { Cariótipo: } 45, \mathrm{XX}, \text { rob(13;15)(q10;q10) } \\
\text { Tomografia computadorizada crânio- } \\
\text { encefálica: normal } \\
\text { Avaliação audiológica:DA } \\
\text { sensorioneural profunda unilateral D }\end{array}$ & $\begin{array}{l}\text { Sínd. de Waardenburg } \\
\text { tipo II } \\
\text { (HAD) }\end{array}$ \\
\hline 76 & M & 3a $1 \mathrm{~m}$ & $\begin{array}{l}\text { Mecha de cabelos mais claros na região } \\
\text { parietal D; hipocromia de íris; deficiência } \\
\text { auditiva; hipopigmentação de pele em } \\
\text { membro inferior D }\end{array}$ & $\begin{array}{l}\text { IMC: } 17 \mathrm{a} / \mathrm{IPC}: 21 \mathrm{a} \quad \text { G2P2A0 } \\
\text { Sem intercorrências gestacionais. } \\
\text { Parto normal; gestação a termo. } \\
\mathrm{PN}=2.850 \mathrm{~g}(3<\mathrm{p}<10) \\
\mathrm{EN}=48 \mathrm{~cm}(3<\mathrm{p}<10) \\
\text { Sem intercorrências perinatais. } \\
\text { Mãe com hipopigmentação de pele e de } \\
\text { cabelos na região cérvico-occipital. }\end{array}$ & $\begin{array}{l}\text { Cariótipo: } 46, \mathrm{XY} \\
\text { Análise molecular: negativo para } \\
\text { mutações no gene PAX3 e MITF } \\
\text { Avaliação audiológica:DA } \\
\text { sensorioneural profunda bilateral }\end{array}$ & $\begin{array}{c}\text { Síndrome de Waardenburg } \\
\text { tipo II } \\
\text { (HAD) }\end{array}$ \\
\hline
\end{tabular}


Continuação TABELA 12: Dados dos indivíduos com deficiência auditiva e envolvimento de tegumento

\begin{tabular}{|c|c|c|c|c|c|c|}
\hline Indivíduo & Sexo & Idade & Sinais clínicos & $\begin{array}{l}\text { Dados gestacionais e perinatais/ } \\
\text { antecedentes pessoais e familiais }\end{array}$ & $\begin{array}{l}\text { Exames complementares e } \\
\text { caracterização da DA }\end{array}$ & $\begin{array}{l}\text { Hipótese diagnóstica } \\
\text { (modelo de herança) }\end{array}$ \\
\hline 77 & M & 2a $10 \mathrm{~m}$ & $\begin{array}{l}\text { Déficit pré e pós-natal; microcefalia; mecha } \\
\text { branca de cabelos e hipopigmentação de } \\
\text { pele em região frontal; fendas palpebrais } \\
\text { oblíquas para baixo; dystopia canthorum; } \\
\text { epicanto bilateral; ćlíios longos; hipotonia } \\
\text { bucal; limitação da abertura bucal; } \\
\text { maloclusão dentária; palato em ogiva; } \\
\text { micrognatia; orelhas proeminentes com anti- } \\
\text { hélices simplificados; deficiência auditiva; } \\
\text { hipopigmentação de pele em membros } \\
\text { superiores e membro inferior E; } \\
\text { contraturas de flexão em mãos, cotovelos e } \\
\text { joelhos; pés planos; hérnia inguinal bilateral; } \\
\text { criptorquidia; hiperatividade; ADNPM }\end{array}$ & $\begin{array}{l}\text { IMC: } 24 \mathrm{a} / \text { IPC: } 22 \mathrm{a} \quad \mathrm{G} 2 \mathrm{P} 1 \mathrm{~A} 1 \\
\text { Ameaço de aborto no } 3^{\circ} \text { mês gestacional. } \\
\text { Uso de antiabortivo. } \\
\text { Parto normal; gestação de } 8 \text { meses. } \\
\mathrm{PN}=1.600 \mathrm{~g}(\mathrm{p}<3) \quad \mathrm{EN}=38 \mathrm{~cm}(\mathrm{p}<3) \\
\text { Apresentou } 3 \text { episódios de pneumonia } \\
\text { após os } 3 \text { meses de idade. } \\
\text { A partir dos } 2 \text { anos de idade, apresentou } \\
\text { crises convulsivas. Uso de Carbamazepina. } \\
\text { Caso isolado. } \\
\text { Aos } 5 \mathrm{a} 4 \mathrm{~m}: \mathrm{P}=10.200 \mathrm{~g}(\mathrm{p}<3) \\
\qquad \mathrm{A}=94 \mathrm{~cm}(\mathrm{p}<3) \\
\mathrm{PC}=43 \mathrm{~cm}(\mathrm{p}<2) ; \text { corrigido } \\
\quad \text { pela altura: } \mathrm{p}<2\end{array}$ & $\begin{array}{l}\text { Cariótipo: } 46, \mathrm{XY} \\
\text { Ressonância magnética do encéfalo: } \\
\text { polimicrogiria difusa } \\
\text { Avaliação audiológica:DA } \\
\text { sensorioneural profunda bilateral }\end{array}$ & $\begin{array}{c}\text { Síndrome de Waardenburg } \\
\text { tipo III } \\
\text { (Klein Waardenburg) }\end{array}$ \\
\hline $78^{*}$ & $\mathrm{~F}$ & $44 a$ & $\begin{array}{l}\text { Mecha branca de cabelos na região } \\
\text { frontal; hipocromia de íris; deficiência } \\
\text { auditiva; hipopigmentação de pele }\end{array}$ & $\begin{array}{l}\text { IMC: 32a / IPC: 36a G13P12A1 } \\
\text { Sem informações gestacionais. } \\
\text { Parto normal; gestação a termo. } \\
\text { PN=? EN=? } \\
\text { Bisavô, avô materno e avô paterno com } \\
\text { hipocromia de íris; pai com heterocromia } \\
\text { de íris; } 1 \text { irmão com mecha branca de } \\
\text { cabelos, DA e hipopigmentação de pele; } 1 \\
\text { prima paterna, em } 2^{\circ} \text { grau, com } \\
\text { heterocromia de íris. }\end{array}$ & $\begin{array}{l}\text { Cariótipo: } 46, \mathrm{XX} \\
\text { Avaliação audiológica: DA } \\
\text { sensorioneural profunda bilateral }\end{array}$ & $\begin{array}{l}\text { Piebaldismo } \\
\text { (HAD) }\end{array}$ \\
\hline
\end{tabular}


Continuação TABELA 12: Dados dos indivíduos com deficiência auditiva e envolvimento de tegumento

\begin{tabular}{|c|c|c|c|c|c|c|}
\hline Indivíduo & Sexo & Idade & Sinais clínicos & $\begin{array}{l}\text { Dados gestacionais e perinatais/ } \\
\text { antecedentes pessoais e familiais }\end{array}$ & $\begin{array}{l}\text { Exames complementares e } \\
\text { caracterização da DA }\end{array}$ & $\begin{array}{l}\text { Hipótese diagnóstica } \\
\text { (modelo de herança) }\end{array}$ \\
\hline 79 & $\mathrm{~F}$ & $7 \mathrm{a} 2 \mathrm{~m}$ & $\begin{array}{l}\text { Mecha branca de cabelos na região frontal } \\
\text { e occipital; hipopigmentação de } \\
\text { sobrancelhas, cílios e pele (face, tronco e } \\
\text { membros); deficiência auditiva; } \\
\text { clinodactilia radial } 5^{\circ} \text { dígito bilateral e ulnar } \\
2^{\circ} \text { dígito bilateral }\end{array}$ & $\begin{array}{l}\text { IMC: } 27 \mathrm{a} / \text { IPC: } 39 \mathrm{a} \quad \mathrm{G} 2 \mathrm{P} 2 \mathrm{~A} 0 \\
\text { Sem intercorrências gestacionais. } \\
\text { Parto cesáreo; gestação a termo. } \\
\mathrm{PN}=3.400 \mathrm{~g}(\mathrm{p}=50) \\
\mathrm{EN}=\text { ? } \\
\text { Sem intercorrências perinatais. } \\
\text { Otites de repetição até os } 4 \text { anos de idade. } \\
\text { Pai e irmã com mecha branca de cabelos } \\
\text { na região frontal; hipopigmentação de } \\
\text { sobrancelhas e pele. }\end{array}$ & $\begin{array}{l}\text { Cariótipo: } 46, \mathrm{XX} \\
\text { Análise molecular: } \\
\text { Avaliação audiológica: DA } \\
\text { sensorioneural profunda bilateral }\end{array}$ & $\begin{array}{l}\text { Piebaldismo } \\
\text { (HAD) }\end{array}$ \\
\hline
\end{tabular}

M=masculino; F=feminino; a/m=idade em ano(s) e mês(es) na primeira avaliação; IMC=idade materna na conceppção; IPC=idade paterna na concep̧̧̃õo; G_P_A_=no de gestações, partos e abortos; PN=peso ao nascimento; EN=estatura ao nascimento; PC=perímetro cefálico; $\mathrm{p}=$ =ercentil; DICI=distância intercantal interna; $\mathrm{DICE}=$ distância intercantal externa; $\mathrm{DA}=$ deficiência auditiva; $\mathrm{D}=$ =direito; $\mathrm{E}=$ =esquerdo; $\mathrm{ADNM}=$ atraso no desenvolvimento neuromotor; ${ }^{*}=$ consangüinidade parental; $\mathrm{HAD}=$ herança autossômica dominante 

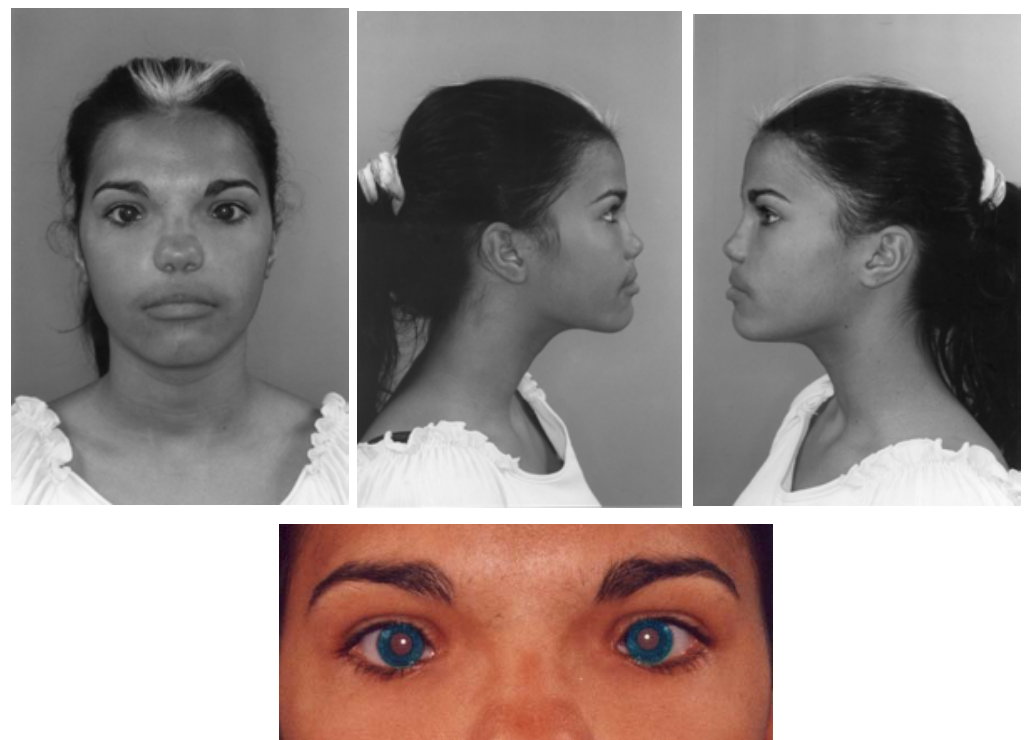

FIGURA 78: Aspectos clínicos do Caso 56

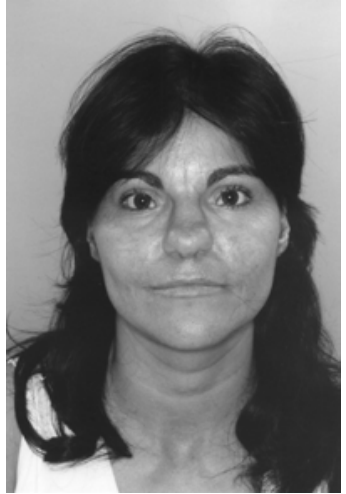

FIGURA 79: Aspectos clínicos da genitora do Caso 56

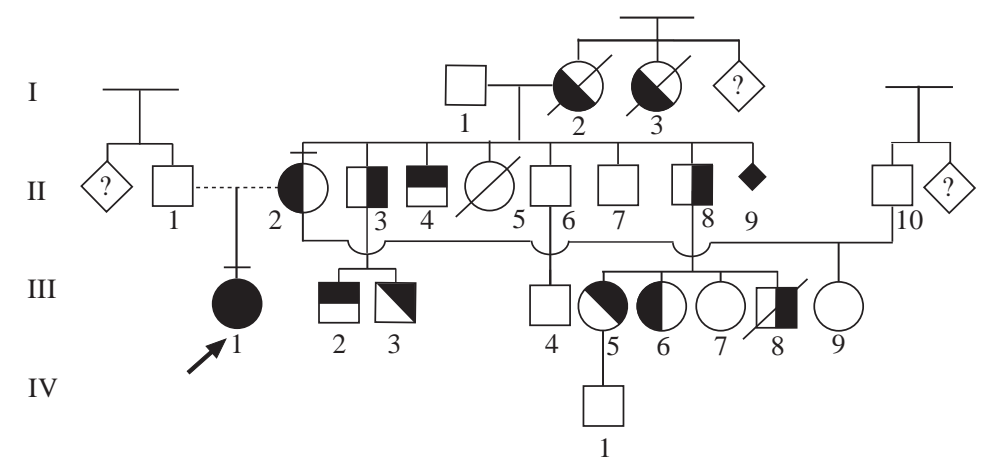

- Propósita

- Telecanto; sinofre; hipopigmentação de pele

- Cabelos grisalhos precocemente; heterocromia de íris; DA; hipopigmentação de pele

- Mecha branca de cabelos, hipocromia de íris;hipopigmentação de pele

- Cabelos grisalhos precocemente; heterocromia de íris

Heterocromia de íris; DA; hipopigmentação de pele

FIGURA 80: Heredograma da família do Caso 56 

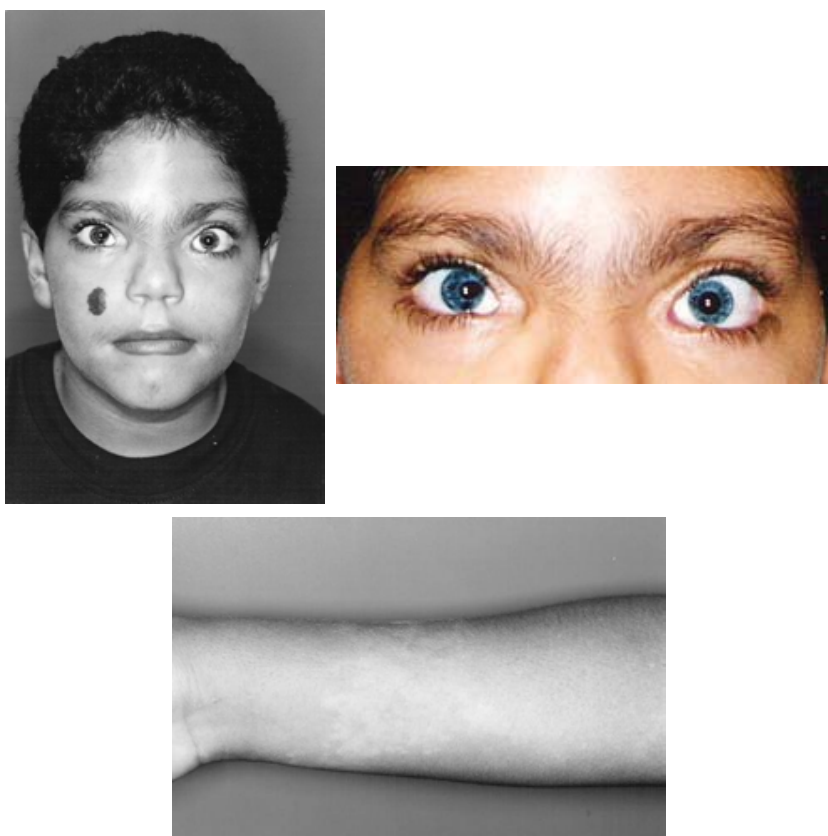

FIGURA 81: Aspectos clínicos do Caso 57 


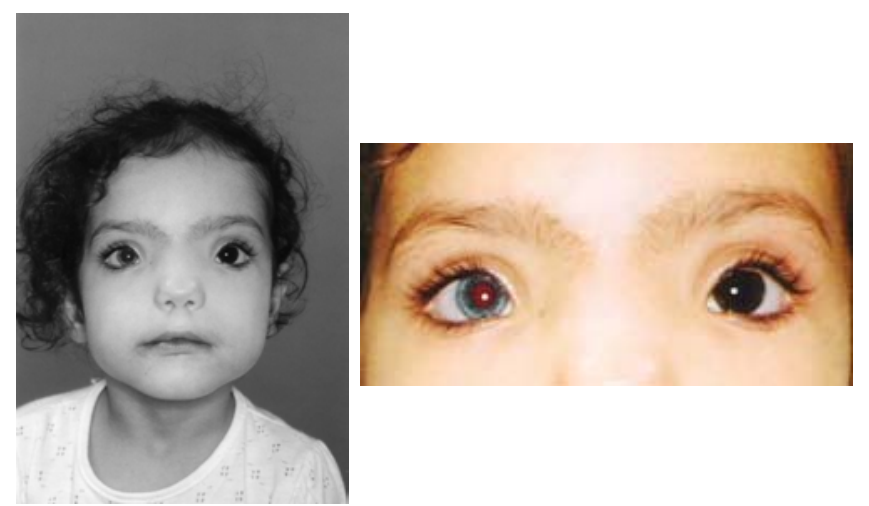

FIGURA 82: Aspectos clínicos do Caso 58

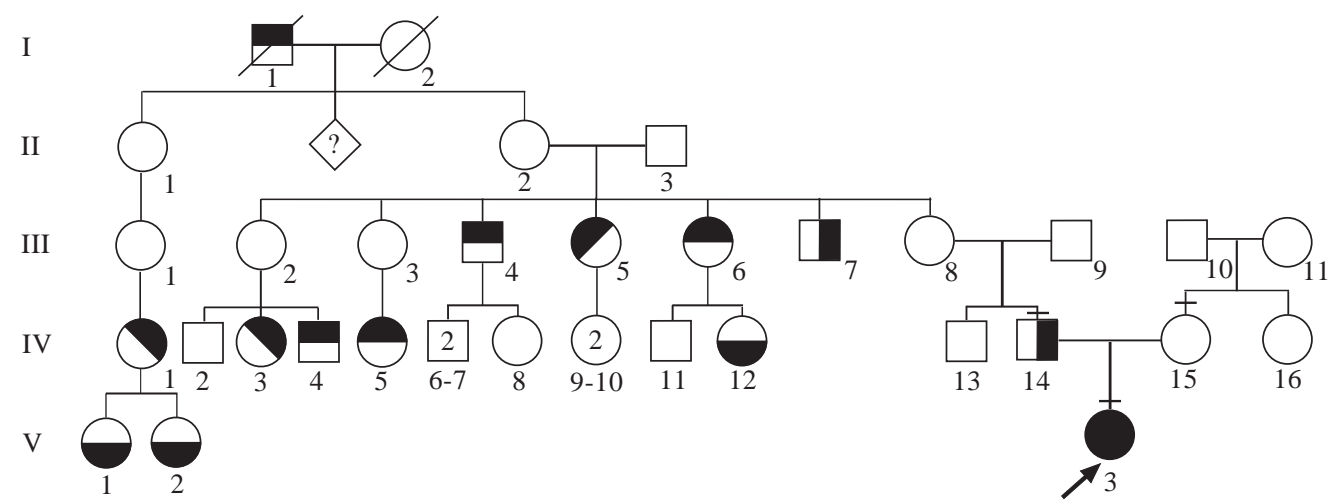

Propósita

- Mecha branca de cabelos; sinofre; hipopigmentação de pele

Mecha branca de cabelos; heterocromia de íris; DA; hipopigmentação de pele

అ Heterocromia de íris; DA

Mecha branca de cabelos; sinofre; DA

Mecha branca de cabelos; DA

- Mecha branca de cabelos, heterocromia de íris

FIGURA 83: Heredograma da família do Caso 58 

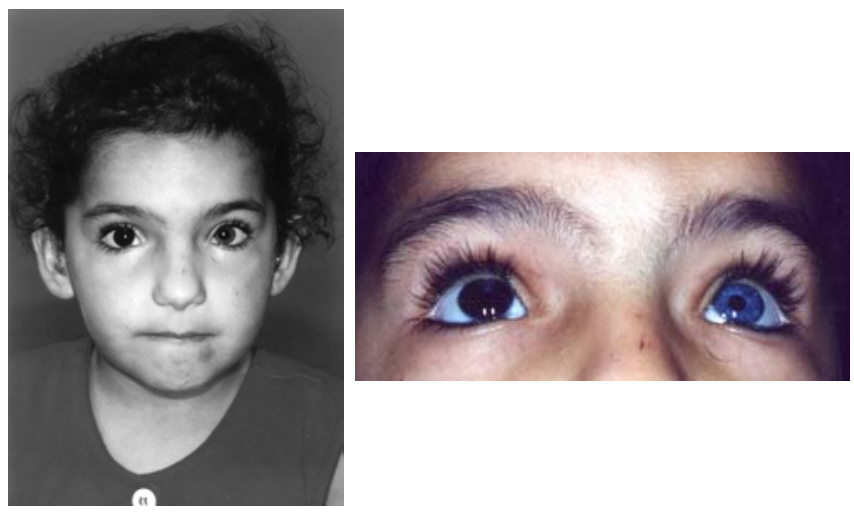

FIGURA 84: Aspectos clínicos do Caso 59

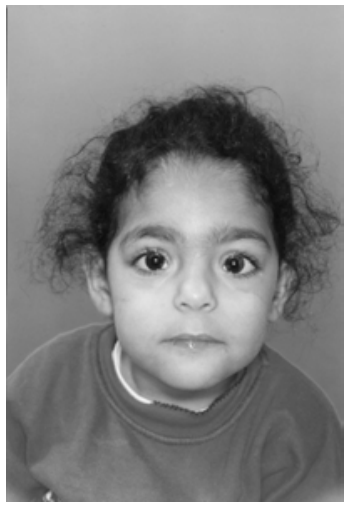

FIGURA 85: Aspectos clínicos do Caso 60

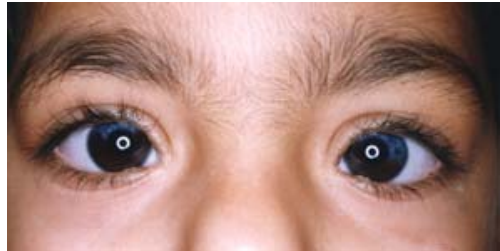

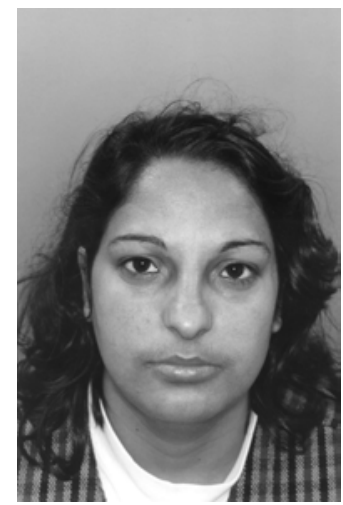

FIGURA 86: Aspectos clínicos da genitora do Caso 60

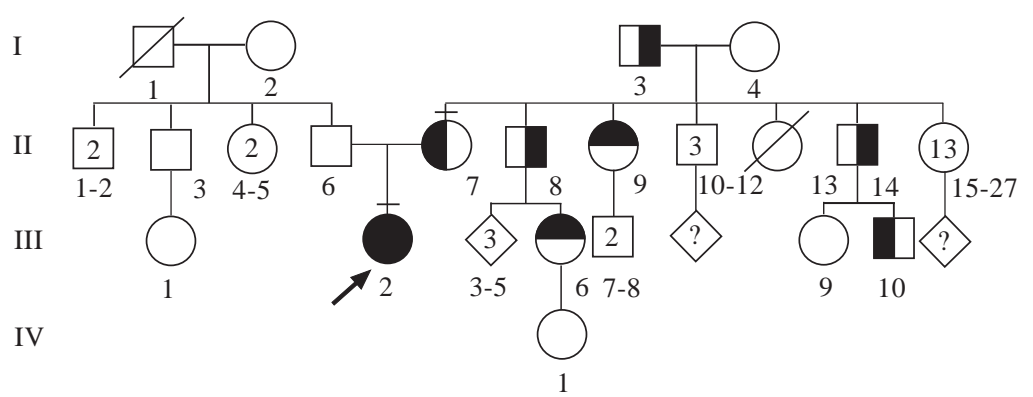

Propósita

D(1) Telecanto; sinofre; hipoplasia asa nasal

Cabelos grisalhos precocemente; sinofre

Sinofre; heterocromia de írisvy

FIGURA 87: Heredograma da família do Caso 60 


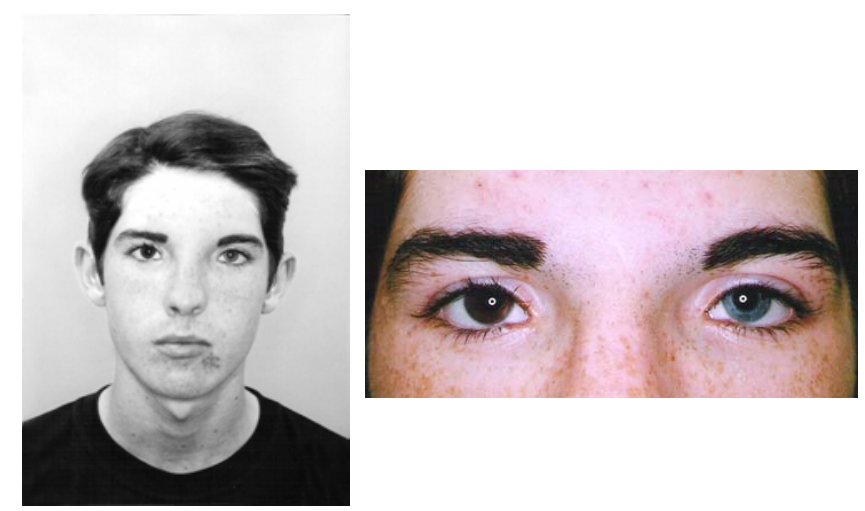

FIGURA 88: Aspectos clínicos do Caso 61

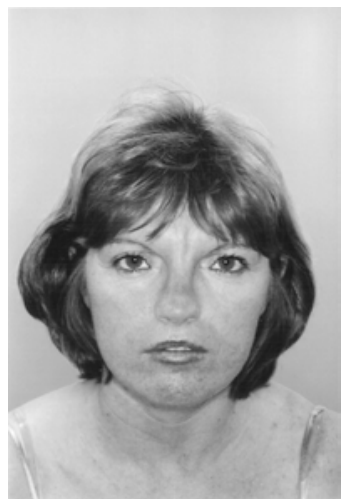

FIGURA 89: Aspectos clínicos da genitora do Caso 61

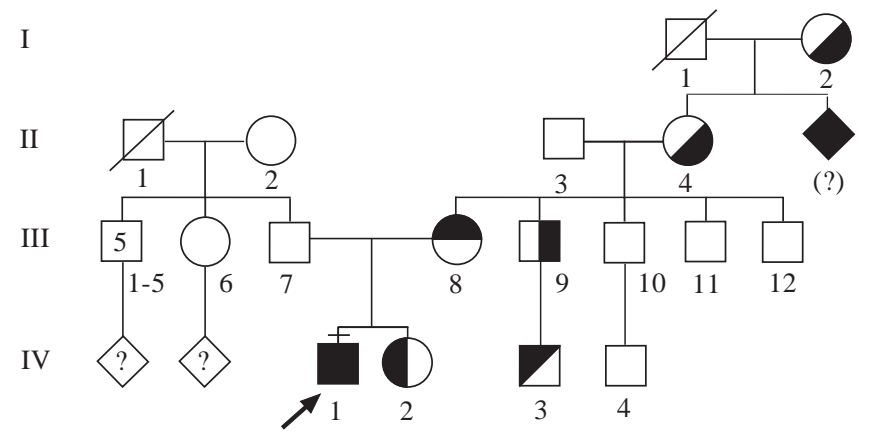

Propósito

Dinofre; telecanto; hipopigmentação de pele

Mecha branca de cabelos; sinofre; telecanto; hipoplasia asa nasal

Mecha branca de cabelos; cabelos grisalhos precocemente; sinofre; telecanto; hipocromia de íris

$\square$ Hipocromia de íris

- Telecanto

- Vários indivíduos afetados

FIGURA 90: Heredograma da família do Caso 61 


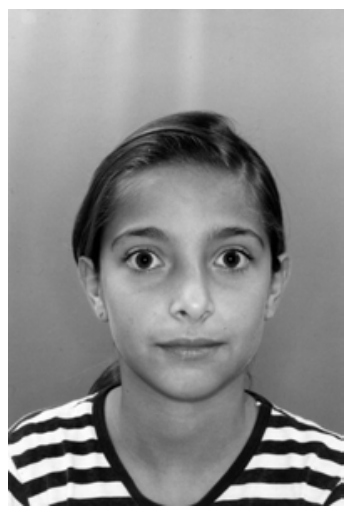

FIGURA 91: Aspectos clínicos do Caso 62

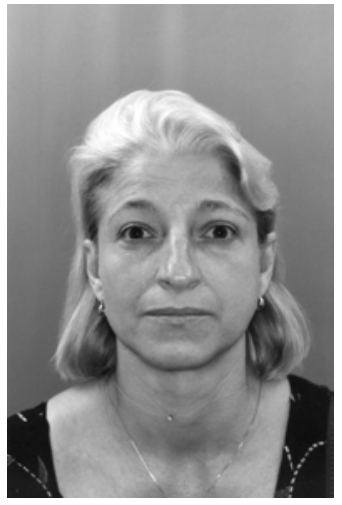

FIGURA 92: Aspectos clínicos da genitora do Caso 62

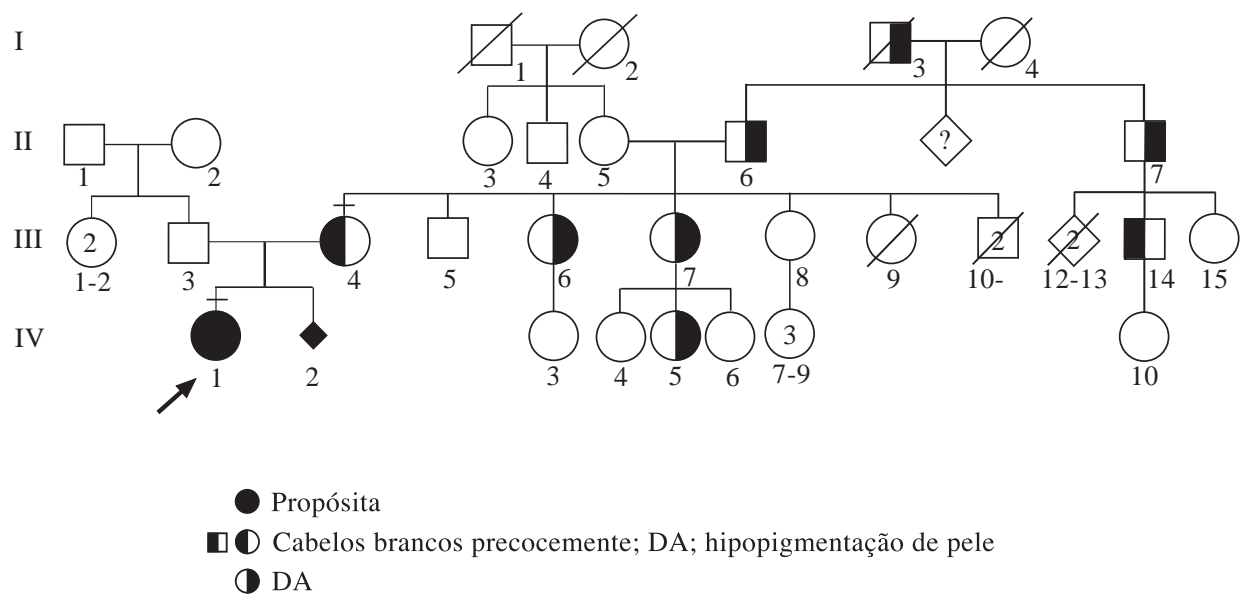

FIGURA 93: Heredograma da família do Caso 62 


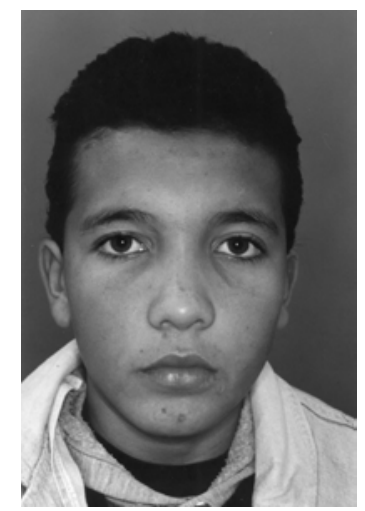

FIGURA 94: Aspectos clínicos do Caso 63

I

II

III

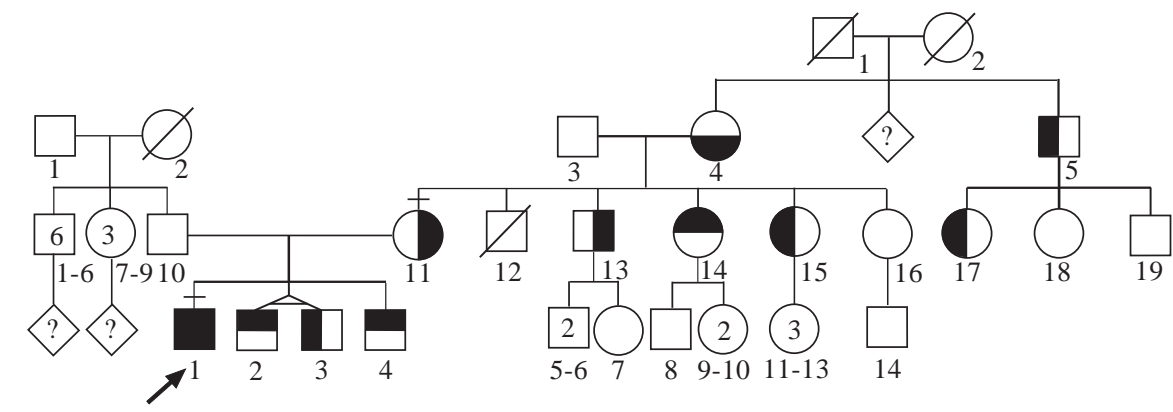

Propósito

I DA

$\odot$ Cabelos grisalhos precocemente

(1) Cabelos grisalhos precocemente; sinofre

Cabelos grisalhos precocemente; DA

FIGURA 95: Heredograma da família do Caso 63 


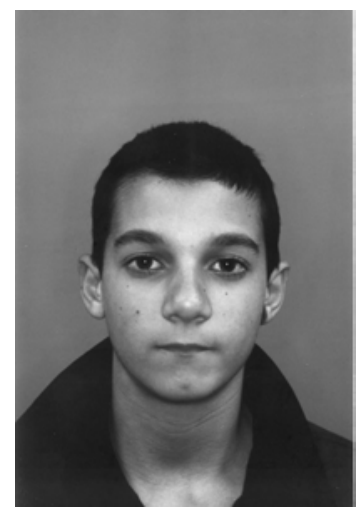

FIGURA 96: Aspectos clínicos do Caso 64

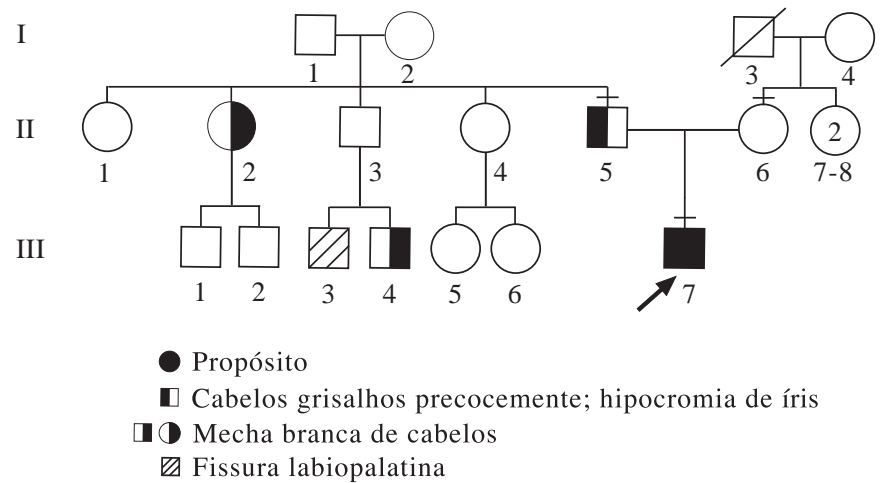

FIGURA 97: Heredograma da família do Caso 64 


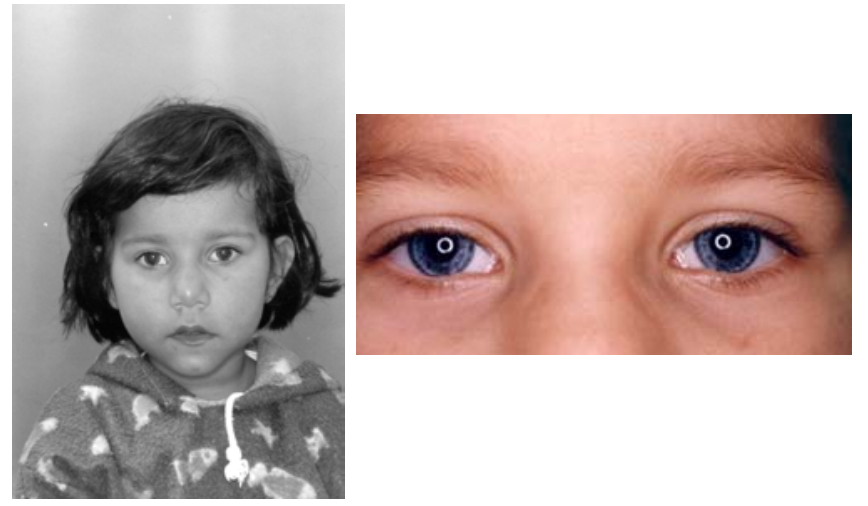

FIGURA 98: Aspectos clínicos do Caso 65

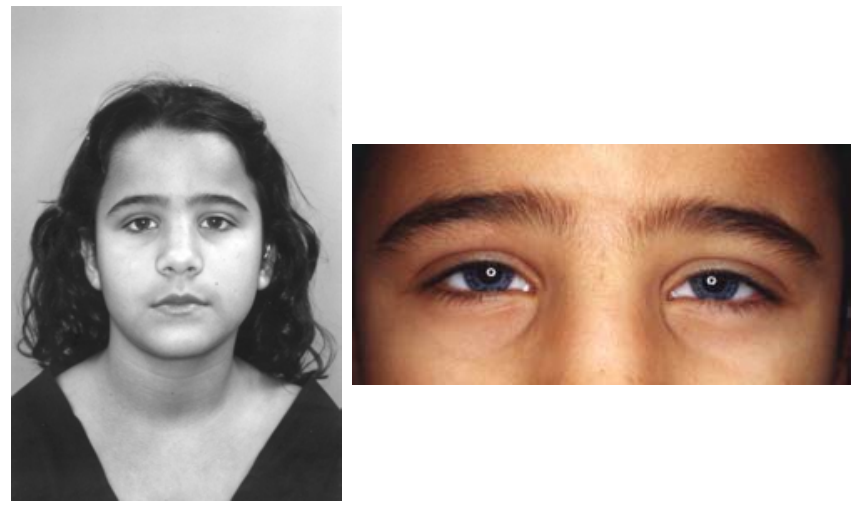

FIGURA 99: Aspectos clínicos do Caso 66

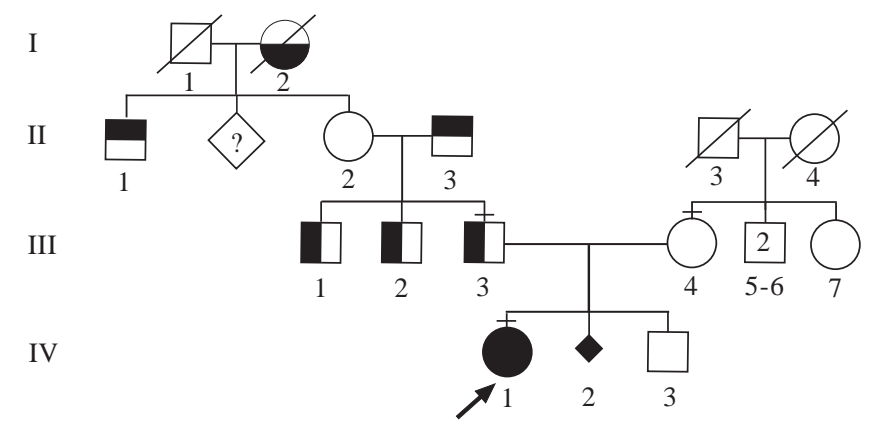

- Propósita

I Sinofre

- Cabelos grisalhos precocemente

DA

$\ominus$ Hipocromia de iris

FIGURA 100: Heredograma da família do Caso 66 

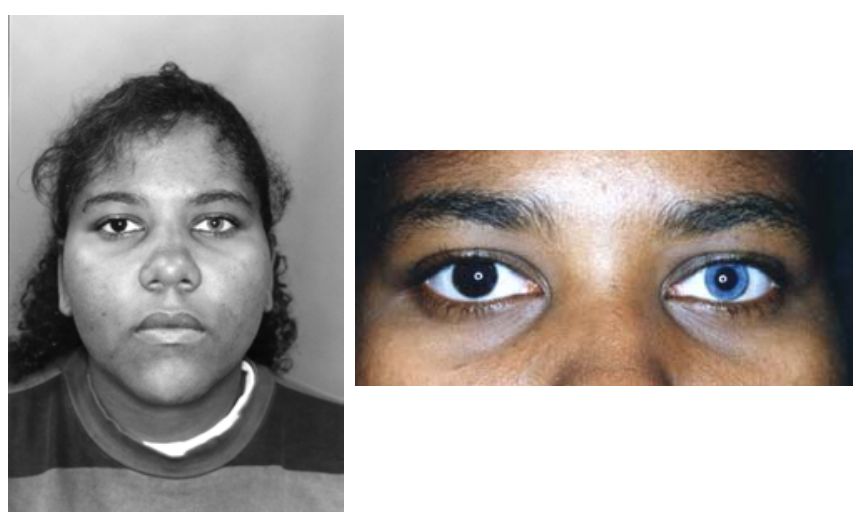

FIGURA 101: Aspectos clínicos do Caso 67

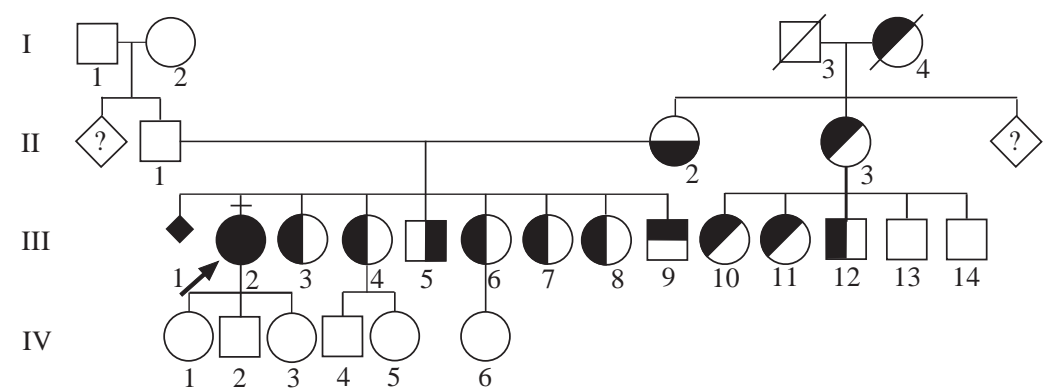

Propósita

11 DA não especificada

Mecha branca de cabelos

- Heterocromia de íris

- Cabelos grisalhos precocemente; DA sensorioneural bilateral

Heterocromia de íris; DA não especificada

FIGURA 102: Heredograma da família do Caso 67

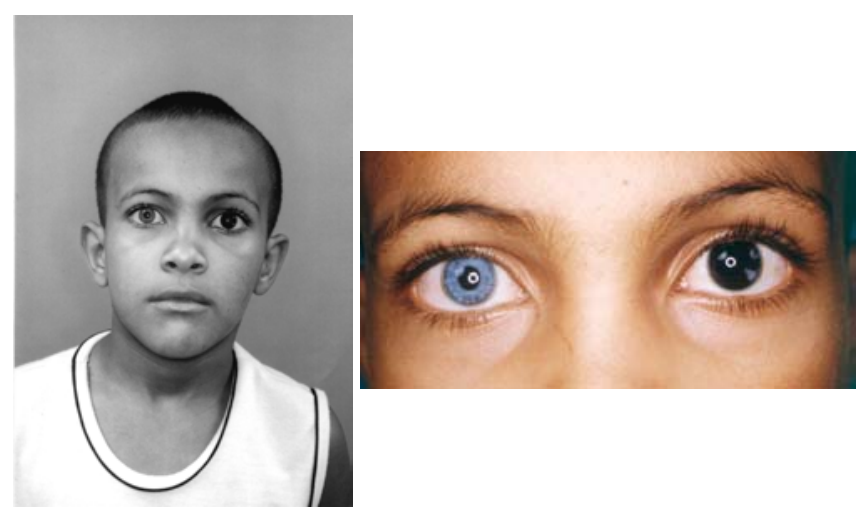

FIGURA 103: Aspectos clínicos do Caso 68 


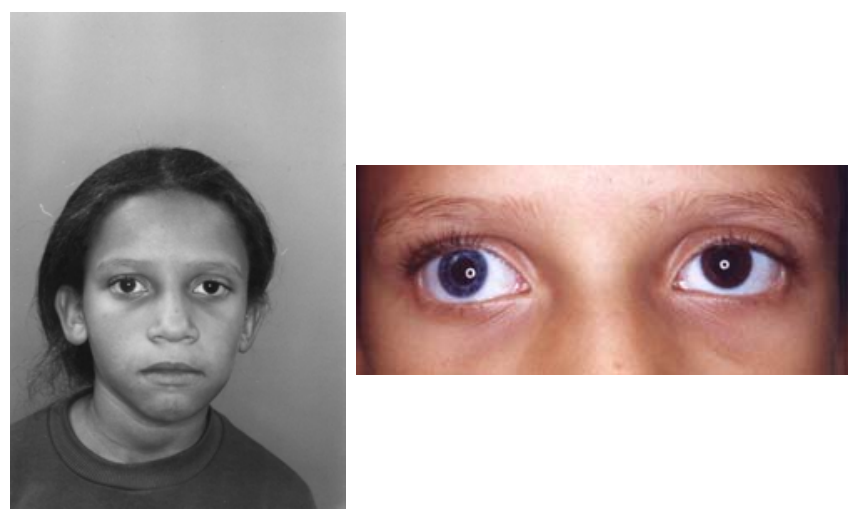

FIGURA 104: Aspectos clínicos do Caso 69
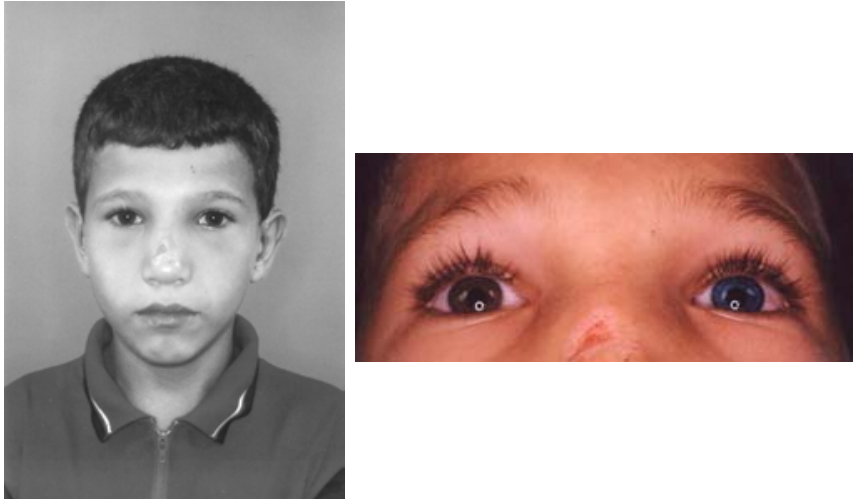

FIGURA 105: Aspectos clínicos do Caso 70

I

II

III

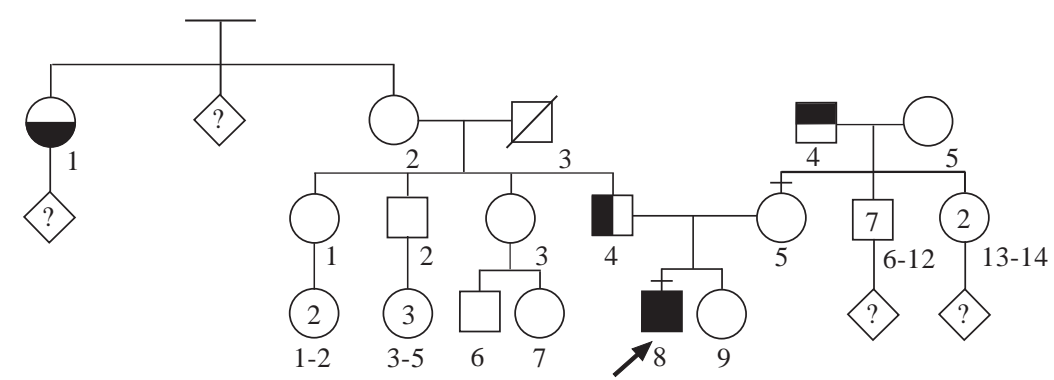

Propósito

D Cabelos grisalhos precocemente

- Hipocromia de íris

Heterocromia de íris

FIGURA 106: Heredograma da família do Caso 70 


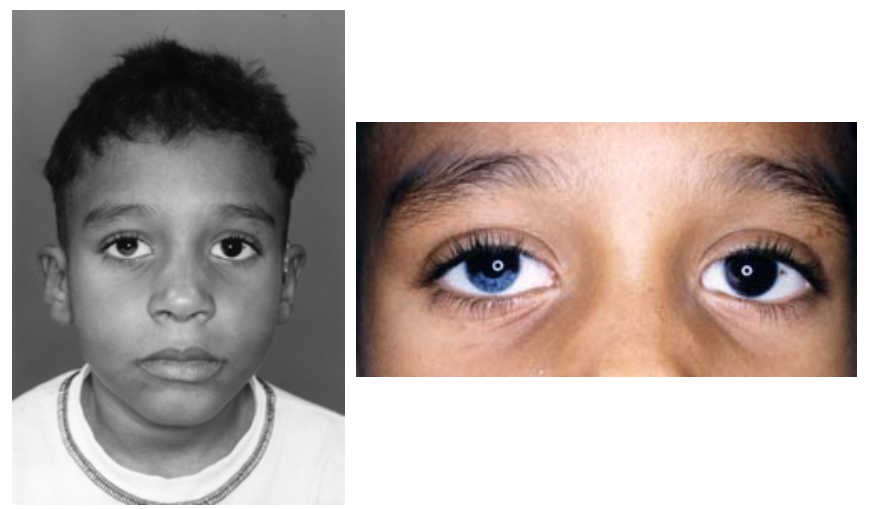

FIGURA 107: Aspectos clínicos do Caso 71

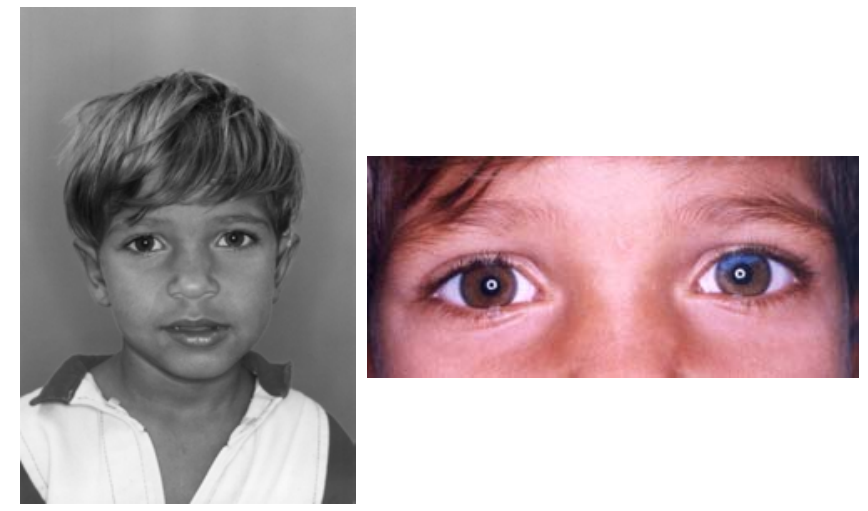

FIGURA 108: Aspectos clínicos do Caso 72 
clínicos do Caso 73

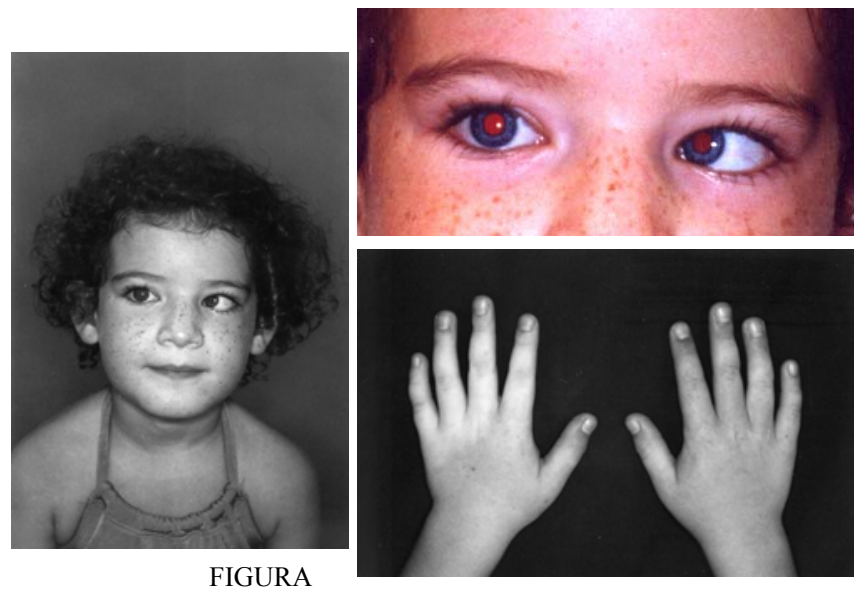

109: Aspectos

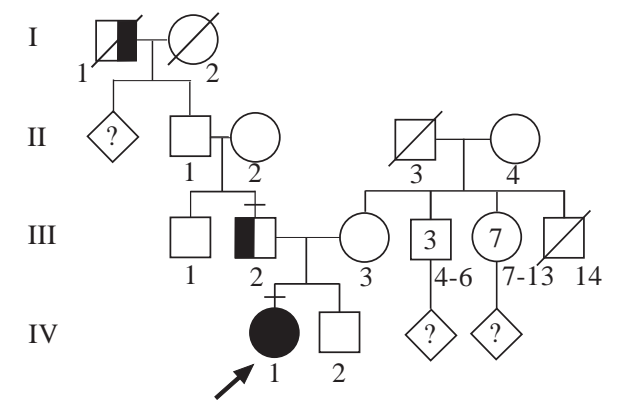

Propósita

\ Sinofre

प Heterocromia de íris

FIGURA 110: Heredograma da família do Caso 73

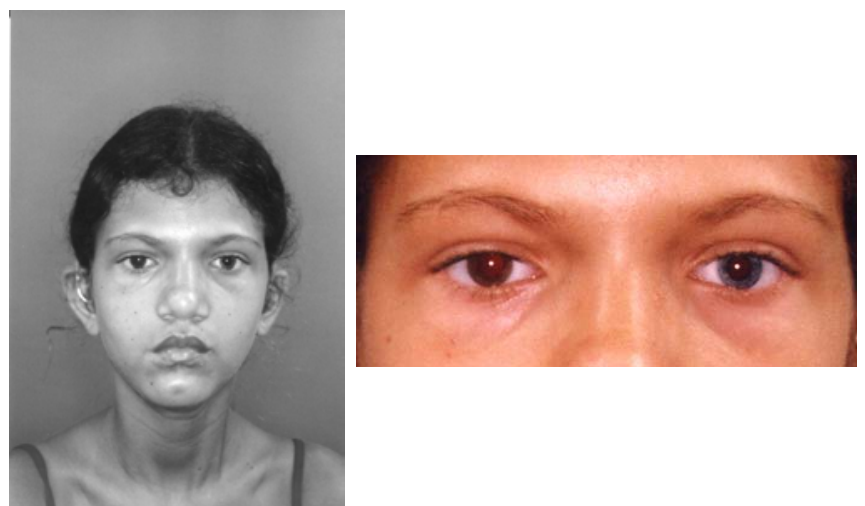

FIGURA 111: Aspectos clínicos do Caso 74 

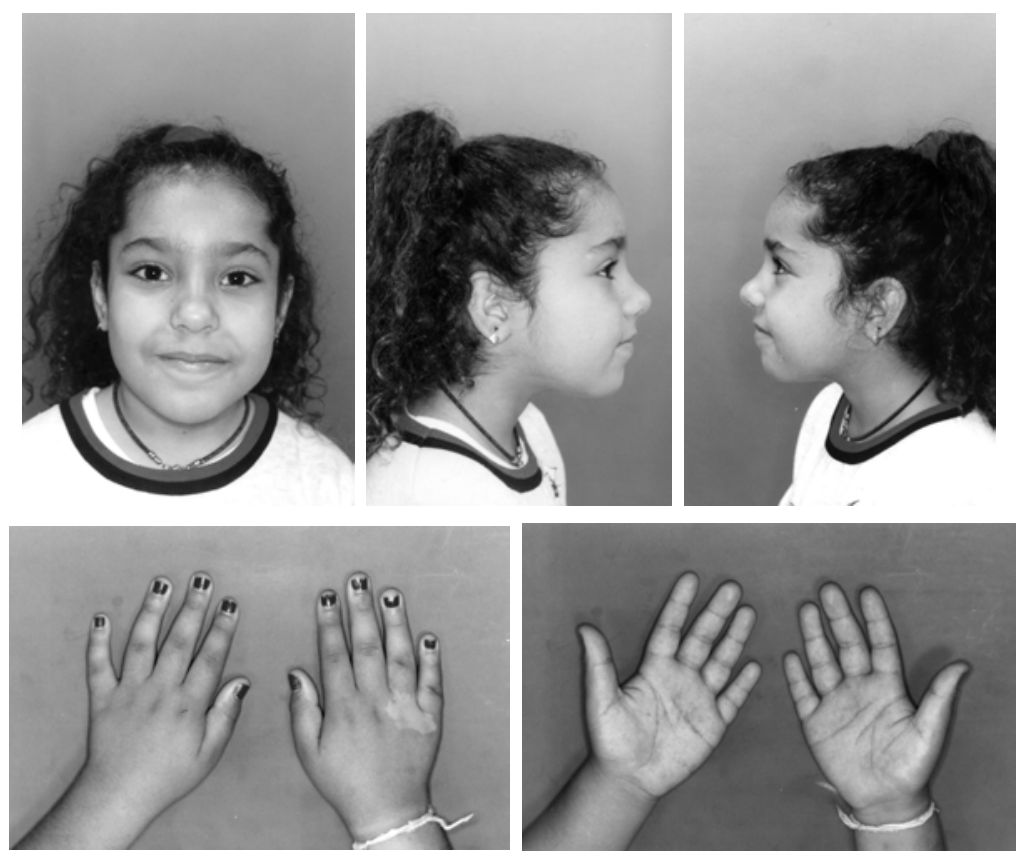

FIGURA 112: Aspectos clínicos do Caso 75
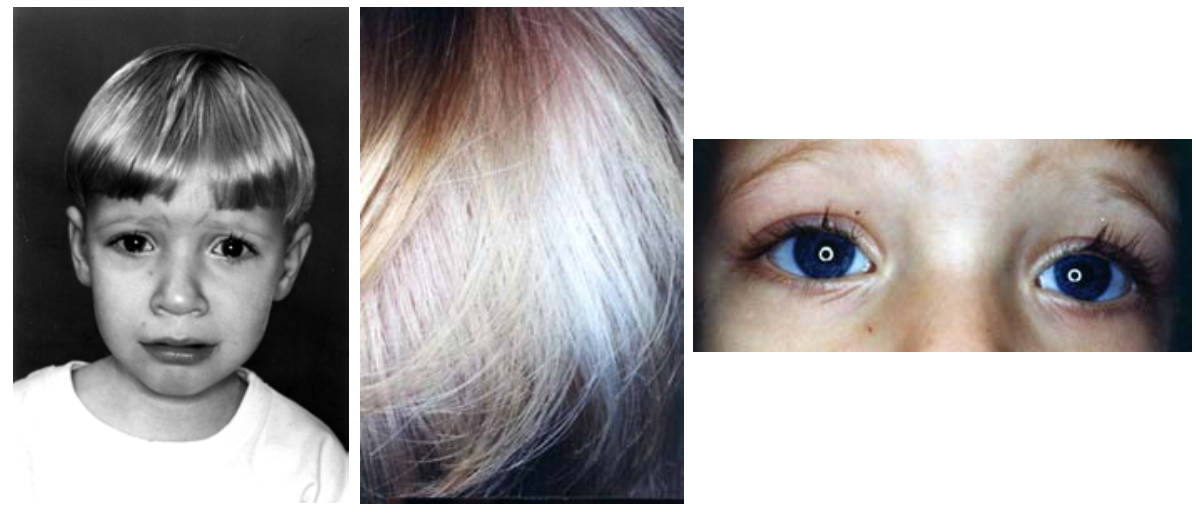

FIGURA 113: Aspectos clínicos do Caso 76 

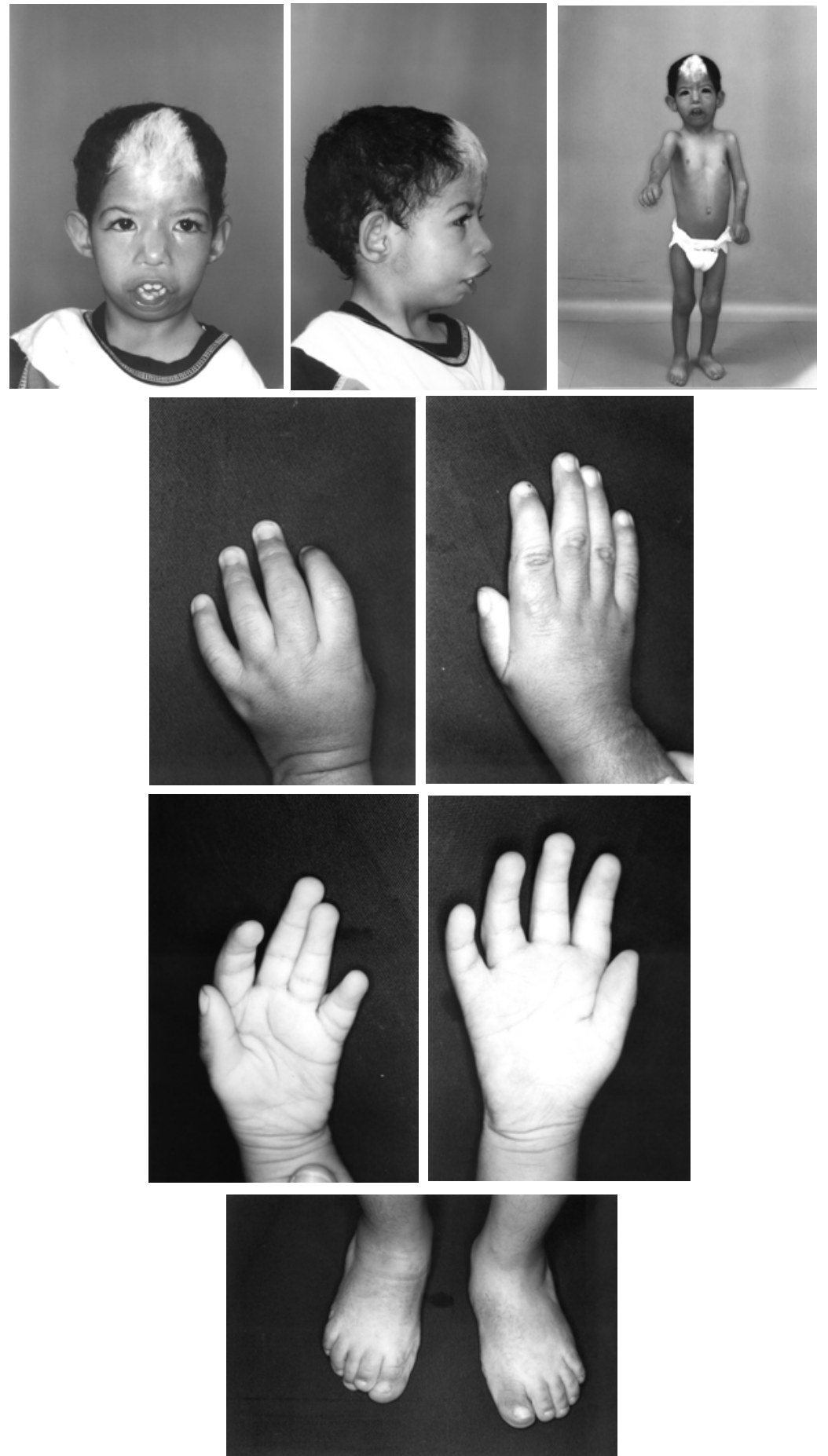

FIGURA 114: Aspectos clínicos do Caso 77 


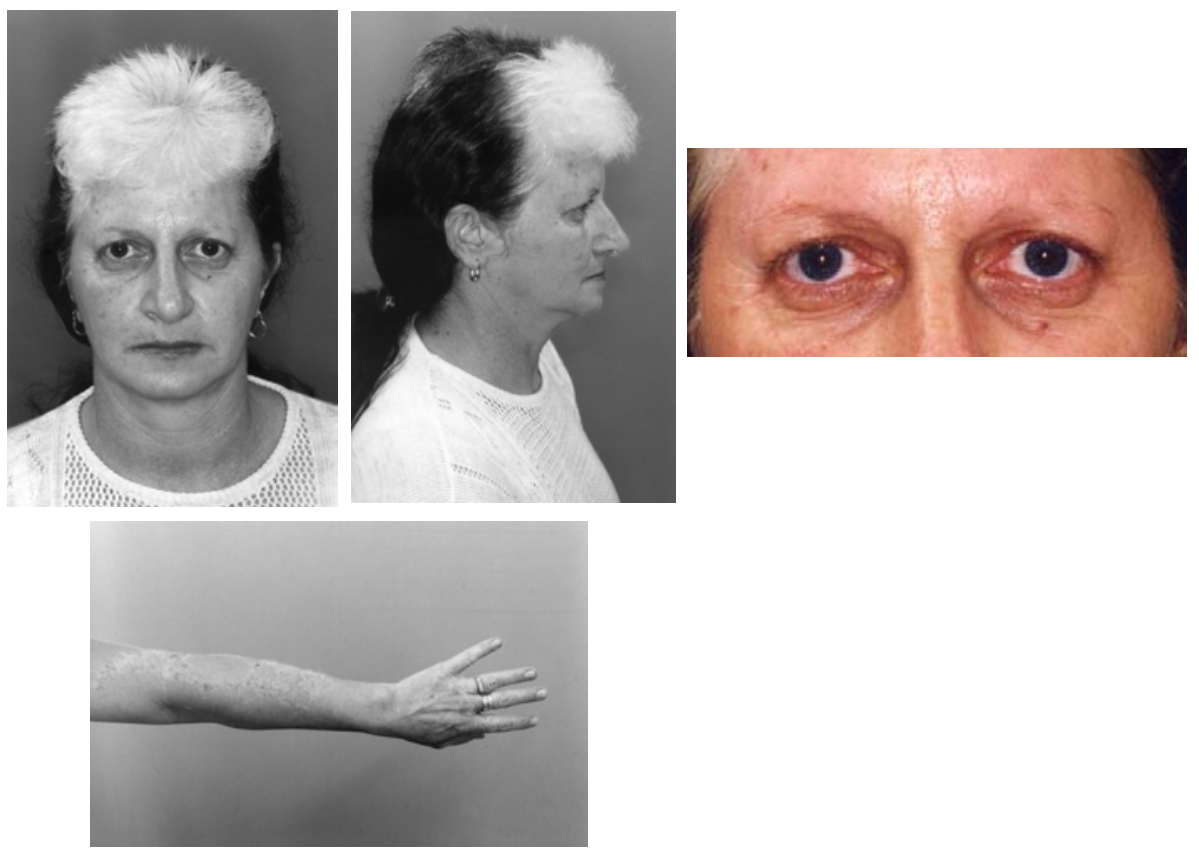

FIGURA 115: Aspectos clínicos do Caso 78

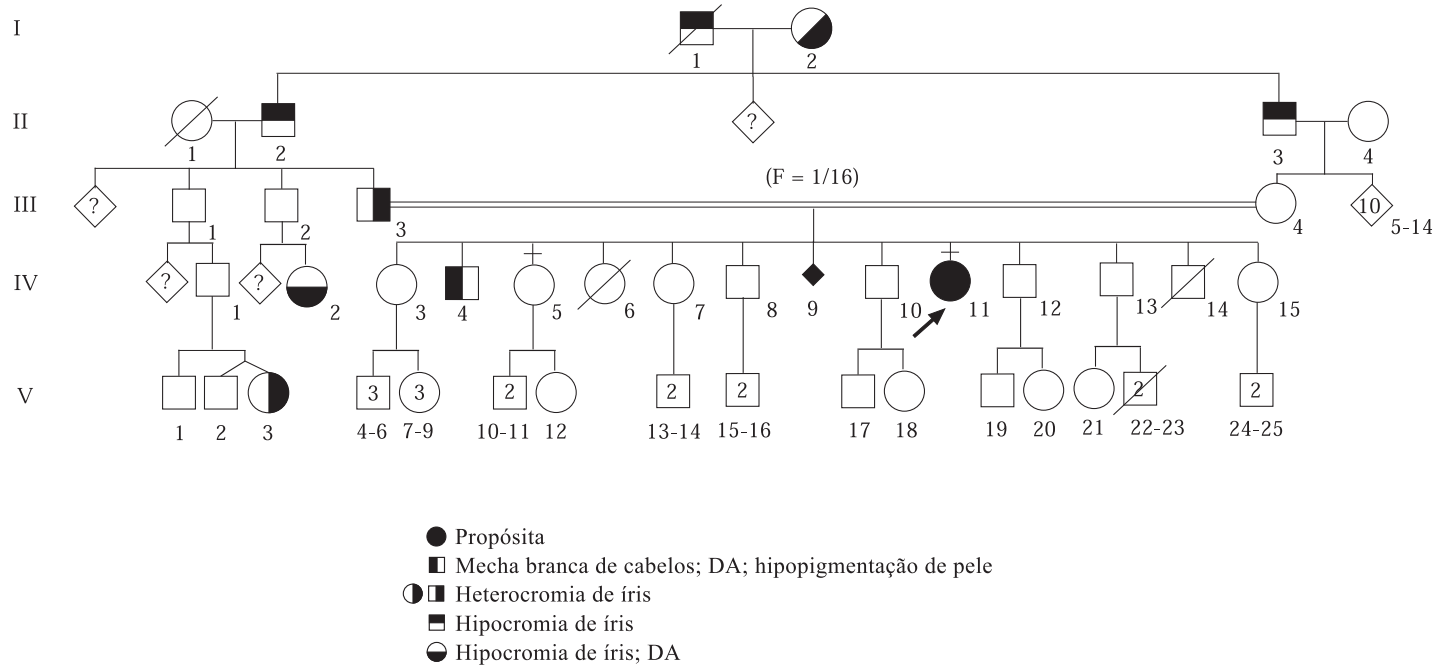

FIGURA 116: Heredograma da família do Caso 78 

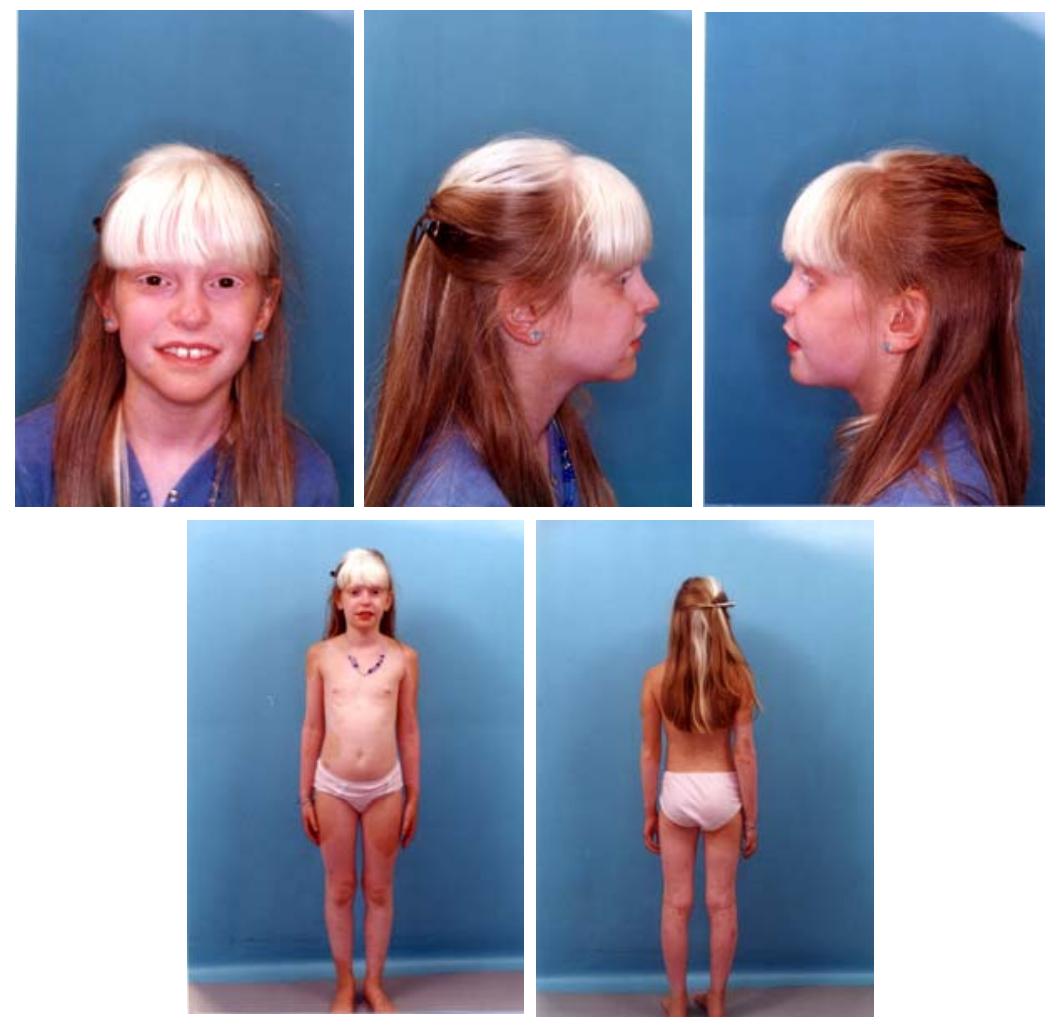

FIGURA 117: Aspectos clínicos do Caso 79

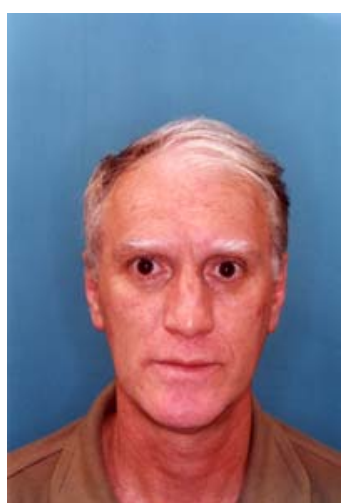

FIGURA 118: Aspectos clínicos do genitor do Caso 79

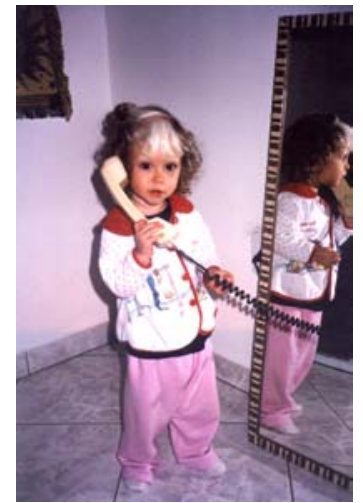

FIGURA 119: Aspectos clínicos da irmã do Caso 79 
I

II

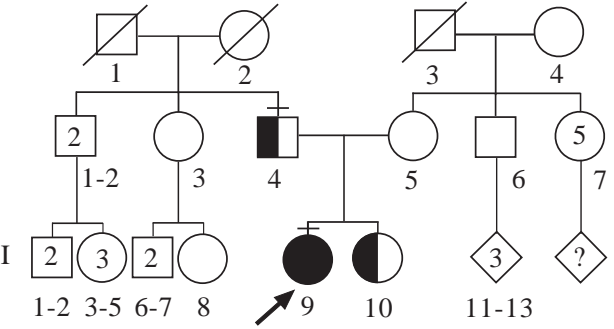

Propósita

$\square$ Mecha branca de cabelos na região frontal; hipopigmentação de pele e de sobrancelhas

FIGURA 120: Heredograma da família do Caso 79 
Associação de deficiência auditiva e alterações de tegumento, resultante de anormalidades de desenvolvimento e de migração das células da crista neural, representa uma classe de anomalias congênitas, que pode fazer parte de algumas síndromes extremamente raras e pouco relatadas na literatura, ou então, parte de outras síndromes relativamente comuns. Dentre as principais síndromes, envolvendo essa associação, encontram-se: síndrome de Waardenburg (OMIM 193500, 193510, 148820, 277580), síndrome de Tietz (OMIM 103500), piebaldismo (OMIM 172800) e piebaldismo com alterações neurológicas (OMIM 172050). A mais conhecida, é a síndrome de Waardenburg (SW), caracterizada, clinicamente, por dismorfismo facial (sinofre, dystopia canthorum, ponte nasal larga, hipoplasia de asa nasal), alterações pigmentares (heterocromia total ou parcial de íris, hipocromia de íris, hipopigmentação de pele, mecha branca de cabelos ou cabelos precocemente grisalhos) e deficiência auditiva sensorioneural congênita. Estima-se que 2\% a 5\% de todos os indivíduos com deficiência auditiva congênita apresentem SW (Gorlin et al 2001). Vários tipos são reconhecidos com base em critérios clínicos e genéticos (Dourmishev et al 1999, Karaman e Aliagaoglu 2006). O tipo I (OMIM 193500) é caracterizado pela presença de dystopia canthorum; o tipo II (OMIM 193510) pela ausência de dystopia canthorum; o tipo III (síndrome Klein-Waardenburg - OMIM 148820) pela presença de dystopia canthorum associada a anomalias músculo-esqueléticas e o tipo IV (síndrome Waardenburg-Shah - OMIM 277580), pela presença da doença de Hirschsprung. Os tipos I, II e III exibem herança autossômica dominante com alta penetrância e variável expressão clínica, tanto intra quanto interfamilial; e, o tipo IV segue o padrão de herança autossômica recessiva (Dourmishev et al 1999, Gorlin et al 2001). Trabalhos recentes têm mostrado que o tipo I e o tipo III estão associados a mutações no gene PAX3; o tipo II está relacionado às mutações no gene MITF (tipo IIa), ao locus WS2B (tipo IIb), ao locus WS2C (tipo IIc) e à deleção no gene SNAI2 (tipo IId); e o tipo IV está associado às mutações no gene EDNRB e SOX10 (Wollnik et al 2003, Tomita e Suzuki 2004, Hakami et al 2006, Karaman e Aliagaoglu 2006). A diferenciação desses quadros deve envolver outros que cursam com alterações pigmentares de pele, cabelos e olhos, principalmente, o quadro de piebaldismo (OMIM 172800) e a síndrome de Tietz (OMIM 103500). A acentuada sobreposição clínica dificulta a definição do quadro, mas o avanço da biologia molecular vem contribuindo, cada vez mais, com esta diferenciação. Na presente casuística, 23 indivíduos (Casos 56 a 80 - Tabela 12) 
apresentaram, além de deficiência auditiva sensorioneural congênita, alterações de tegumento, concordantes com o diagnóstico da síndrome de Waardenburg. Desses indivíduos, seis (Casos 56 a 61 - Figuras 78, 81, 82, 84, 85 e 88, respectivamente) apresentaram, entre outros achados clínicos do quadro, dystopia canthorum, característica sine qua non para o diagnóstico de síndrome de Waardenburg tipo I; quinze indivíduos (Casos 62 a 76 - Figuras 91 a 113) eram clinicamente compatíveis com síndrome de Waardenburg tipo II e, finalmente, um indivíduo (Caso 77 - Figura 114) apresentou dystopia canthorum, anomalias tegumentares e músculo-esqueléticas, compatível com síndrome de Waardenburg tipo III. Observou-se que, nesse grupo de indivíduos, a SW tipo II ocorreu em $71.4 \%$ dos casos e a SW tipo I, em $28.6 \%$, dados esses condizentes com os da literatura (Gorlin et al 2001). Clinicamente, os indivíduos com o tipo I (aparência facial típica) e o tipo II (ausência de dismorfismo facial) se mostraram similares aos relatados em literatura. Cabe salientar que, leve atraso no desenvolvimento neuromotor, observado em $46.7 \%$ dos indivíduos diagnosticados como tipo II, não foi relatado, até então, nessa condição. $\mathrm{Na}$ presente casuística, alteração de pigmento de pele foi observada em $66.7 \%$ dos indivíduos diagnosticados com o tipo I e, em 20.0\% daqueles com o tipo II. De acordo com Gorlin et al (2001), esta alteração é mais freqüentemente encontrada nos indivíduos com o tipo II, no qual a deficiência auditiva também é mais freqüente. Em relação à deficiência auditiva dos indivíduos com o tipo I e tipo II, da presente casuística, observou-se que perda auditiva bilateral foi observada em $100 \%$ dos indivíduos com SW tipo I e em $80.0 \%$ dos indivíduos com SW tipo II. Segundo dados de literatura, perda auditiva bilateral ocorre em $20 \%$ dos indivíduos com tipo I e em 55\% daqueles com tipo II. Essa diferença está, provavelmente, relacionada aos diferentes critérios de inclusão dos indivíduos na presente casuística e nos trabalhos de literatura (Gorlin et al 2001). Em relação à etiologia da SW, história familial negativa para essa condição, sugerindo quadro decorrente de mutação nova, foi observada em sete indivíduos $(33.3 \%)$ da presente casuística. Segundo Preus et al (1983), cerca de 25\% dos casos relatados estão relacionados à mutação nova. Consangüinidade parental, achado fortuito, foi observada nos Casos 68, 71 e 78 (Tabela 12; Figuras 103, 107 e 115, respectivamente). Análise molecular foi realizada nos Casos 65 e 76, ambos com diagnóstico clínico de SW tipo II. No Caso 65 (Figura 98), obteve-se resultado negativo para mutações no gene PAX3. Esse fato não confirma o diagnóstico clínico da SW tipo II, mas exclui a SW tipo I e III. 
Já, no Caso 76 (Figura 113), o resultado mostrou-se negativo tanto para mutações no gene $P A X 3$ quanto para mutações no gene $M I F T$, o que excluem SW tipo I, SW tipo IIa e SW tipo III. Clinicamente, esse indivíduo é muito similar àqueles com a síndrome de Tietz (OMIM 103500), síndrome alélica à SW tipo IIa. Do ponto de vista molecular, este quadro pode ser causado por mutação no gene MIFT, mutação essa não detectada no Caso 76. Possivelmente, esse indivíduo apresente um dos outros subtipos da SW tipo II. Estudo citogenético foi realizado em 12 dos 21 indivíduos com SW e mostrou-se alterado apenas no Caso 75 (Figura 112), onde se detectou translocação robertsoniana entre os cromossomos 13 e 15 . Como indivíduos com translocação robertsoniana são fenotipicamente normais (Nussbaum et al 2002), as manifestações clínicas, presentes no Caso 75 e, compatíveis com SW tipo II, não estão relacionadas com o achado citogenético. Importante, nesse caso, orientações ao indivíduo em questão, pois, embora não haja alteração fenotípica relacionada a esse tipo de translocação, há risco de gametas não balanceados e, portanto, de prole não balanceada. Cabe, ainda, comentar que infecção exantemática não especificada, ocorrida no terceiro mês gestacional, pode ou não, ter exercido alguma influência na etiologia da deficiência auditiva do Caso 61 (Figura 87).

O Caso 77 (Tabela 12; Figura 114), da presente amostra, apresentou achados clínicos compatíveis com a SW tipo III ou síndrome de Klein-Waardenburg, forma mais rara e caracterizada, clinicamente, pela presença de anomalias músculoesqueléticas associada a dismorfismo facial típico da SW tipo I. As anomalias músculoesqueléticas podem variar em grau e, geralmente, cursam com hipoplasia músculoesqueléticas; comprometimento de flexão de cotovelos, pulsos e mãos; fusão de ossos carpais e sindactilia cutânea de dígitos. Perda auditiva sensorioneural congênita uni ou bilateral, tem sido observada na maioria dos indivíduos com a SW tipo III (Gorlin et al 2001). Outros achados clínicos como microcefalia, fissura de palato e atraso mental, podem estar presentes nessa condição (Sheffer e Zlotogora 1992). Até o momento, poucos casos foram relatados (maioria esporádica) e modelo de herança autossômica dominante, com expressividade variável, tem sido observado (Senrui 1984, Sheffer e Zlotogora 1992, Tekin et al 2001). Estudos recentes têm mostrado que a SW tipo III ocorre quando o indivíduo é homozigoto para a mutação no gene $P A X 3$ (Wollnik et al 2003). Em relação ao Caso 77, da presente casuística, o fenótipo facial, as manifestações músculo-esqueléticas e, ainda, o tipo de deficiência auditiva são 
característicos e similares aos dos indivíduos previamente relatados com a síndrome de Klein-Waardemburg. Já, microcefalia, maloclusão dentária e palato alto, outros achados clínicos do Caso 77, são incomuns nessa condição (Klein 1983, Sheffer e Zlotogora 1992). Em relação ao diagnóstico diferencial, considerou-se, principalmente a síndrome craniofacial-surdez-mão (OMIM 122880), excluída por não cursar com hipopigmentação de cabelos e, o quadro de piebaldismo com alterações neurológicas (OMIM 172850), por não cursar com anomalias músculo-esqueléticas.

Alguns indivíduos, pertencentes a esse grupo (Caso 78 e 79 - Tabela 12; Figuras 115 e 117, respectivamente), apresentaram envolvimento tegumentar mais acentuado do que o observado naqueles com diagnóstico de síndrome de Waardenburg. $\mathrm{Na}$ presença de comprometimento mais acentuado, envolvendo hipopigmentação de pele e de cabelos, o quadro de piebaldismo (OMIM 172800) deve ser considerado como diagnóstico. Esse é um quadro raro, com modelo de herança autossômica dominante, cuja característica peculiar é a presença de hiperpigmentação das bordas das áreas despigmentadas. Heterocromia de íris ocorre em alguns desses indivíduos e deficiência auditiva congênita, quando presente, é sensorioneural (Spritz e Beighton 1998). Mutações no gene KIT, localizado no 4q12 e deleção do gene SNAI2 foram relacionados a essa condição (Sanchez-Martin et al 2003, Deng et al 2005). Na presente casuística, os Casos 78 (Figura 116; IV-11) e 79 (Figura 120; III-9) apresentaram despigmentação de pele (região frontal, queixo, tronco e membros), de cabelos (região frontal) e de sobrancelhas típicos do quadro de piebaldismo. Ambos os casos apresentaram deficiência auditiva sensorioneural profunda. Consangüinidade parental, presente no Caso 78, é fortuita e, herança autossômica dominante foi evidenciada pela recorrência familial que mostrou afetados em cinco gerações (Figura 116). A expressividade clínica do quadro, nesses afetados, foi variável. Deficiência auditiva foi referida apenas nos indivíduos IV-2 e IV-4 (Figura 116), que apresentaram, ainda, hipocromia de íris e despigmentação de pele e cabelo. Hipocromia de íris, presente no Caso 78 e nos indivíduos II-2 e IV-2 (Figura 116) não é achado comum do piebaldismo. Recorrência familial, com afetados em duas gerações, foi, também, observada no Caso 79 (Figura 120). Clinicamente, despigmentação de pele (região frontal, queixo e membros), de cabelos e de sobrancelhas, típica do quadro de piebaldismo, foi observada no genitor (Figura 120; II-4) e em uma irmã (Figura 120; III-10). Ambos tinham audição normal. Importante salientar que, apesar da sobreposição clínica entre os quadros que cursam 
com despigmentação de tegumento, alguns achados como: dismorfismo facial, alterações músculo-esqueléticas, áreas extensas de despigmentação, envolvimento neurológico, sinalizam para determinado diagnóstico. Em relação ao piebaldismo, quando na presença de deficiência auditiva, a diferenciação clínica com a SW tipo II torna-se difícil. 


\subsubsection{Grupo 7: Miscelânea (indivíduos com deficiência auditiva e anomalias diversas) (Casos 80 a 82)}

Fizeram parte desse grupo, indivíduos com deficiência auditiva associada a múltiplas anomalias, os quais não se enquadraram nos grupos anteriores. Dos 3 indivíduos, o Caso 80 apresentou sinais clínicos compatíveis com a síndrome CoffinLowry; o Caso 81 com a síndrome velocardiofacial (síndrome da deleção 22q11.2) e, o Caso 82 apresentou achados clínicos que direcionaram para a síndrome de Heimler. Entre os indivíduos desse grupo, 2 apresentaram deficiência auditiva sensorioneural e 1, deficiência auditiva condutiva. Na Tabela 13, encontram-se os dados referentes a esse grupo. 
TABELA 13: Dados dos indivíduos com deficiência auditiva e anomalias diversas (miscelânea)

\begin{tabular}{|c|c|c|c|c|c|c|}
\hline Indivíduo & Sexo & Idade & Sinais clínicos & $\begin{array}{l}\text { Dados gestacionais e perinatais/ } \\
\text { antecedentes pessoais e familiais }\end{array}$ & $\begin{array}{l}\text { Exames complementares e } \\
\text { caracterização da DA }\end{array}$ & $\begin{array}{l}\text { Hipótese diagnóstica } \\
\text { (modelo de herança) }\end{array}$ \\
\hline 80 & M & 3a $1 \mathrm{~m}$ & $\begin{array}{l}\text { Fronte ampla; sutura metópica proeminente; } \\
\text { hemangioma plano em região frontal, ponte } \\
\text { nasal e filtro; hipertelorismo ocular; epicanto } \\
\text { bilateral; fendas palpebrais oblíquas para } \\
\text { baixo; base e ponte nasal largas; boca grande } \\
\text { e triangular; maloclusão dentária; queixo } \\
\text { pequeno; deficiência auditiva; dígitos } \\
\text { curtos, largos, hiperextensíveis e com } \\
\text { falanges distais afiladas; unhas convexas; pé } \\
\text { torto congênito bilateral; hipospadia; } \\
\text { hipotonia generalizada quando bebê; } \\
\text { hiperatividade; ADNPM }\end{array}$ & $\begin{array}{l}\text { IMC: 26a / IPC: 30a G1P1A0 } \\
\text { Realizou ultrassonografia no início } \\
\text { gestacional. Transnucência nucal: } 3.2 \text {. } \\
\text { Realização de amniocentese: normal. } \\
\text { Parto cesáreo; gestação a termo. } \\
\text { PN= 2.670g (p=3) EN= } 47 \mathrm{~cm}(\mathrm{p}=3) \\
\text { Aos } 5 \text { meses de idade, apresentou hepatite } \\
\text { A. } \\
\text { Aos } 7 \text { meses, realizou cirurgia para } \\
\text { correção da hipospadia. } \\
\text { Aos 3a 1m: DICI= 3.3cm (p }>97) \\
\quad \text { DICE= } 8.9 \mathrm{~cm}(\mathrm{p}>97) \\
\text { Mãe com base nasal baixa e alargada, } \\
\text { dígitos largos, curtos e hiperextensíveis; } \\
\text { falanges distais afiladas; unhas convexas. }\end{array}$ & $\begin{array}{l}\text { Cariótipo: } 46, \mathrm{XY} \\
\text { Biópsia muscular: atrofia de fibras tipo } \\
\text { II } \\
\text { Exame histopatológico: normal } \\
\text { TORCH: negativo } \\
\text { Ecografia transfontanela: normal } \\
\text { Ressonância magnética encéfalo: } \\
\text { normal } \\
\text { Cariótipo da mãe: normal } \\
\text { Avaliação audiológica: DA } \\
\text { sensorioneural profunda bilateral }\end{array}$ & $\begin{array}{l}\text { Síndrome Coffin-Lowry } \\
\text { (HL-X dominante) }\end{array}$ \\
\hline
\end{tabular}


Continuação TABELA 13: Dados dos indivíduos com deficiência auditiva e anomalias diversas (miscelânea)

\begin{tabular}{|c|c|c|c|c|c|c|}
\hline Indivíduo & Sexo & Idade & Sinais clínicos & $\begin{array}{l}\text { Dados gestacionais e perinatais/ } \\
\text { antecedentes pessoais e familiais }\end{array}$ & $\begin{array}{l}\text { Exames complementares e } \\
\text { caracterização da DA }\end{array}$ & $\begin{array}{l}\text { Hipótese diagnóstica } \\
\text { (modelo de herança) }\end{array}$ \\
\hline 81 & M & $8 \mathrm{a} 3 \mathrm{~m}$ & $\begin{array}{l}\text { Baixa estatura; hipoplasia malar; fendas } \\
\text { palpebrais estreitas; estrabismo convergente; } \\
\text { ponte nasal alongada; hipoplasia asa nasal; } \\
\text { filtro longo; fissura de palato submucosa; } \\
\text { apêndices pré-auriculares à D; deficiência } \\
\text { auditiva; cardiopatia congênita; polidactilia } \\
\text { pós-axial bilateral; sindactilia cutânea parcial } \\
\text { entre os dígitos } 3-4 \text { à D; pregas vestigiais } \\
\text { interdigitais bilateral; pés pequenos; } \\
\text { sindactilia entre os artelhos 1-2 e agenesiado } \\
\text { raio } 3 \text { hálux alargadoà E com fissura plantar } \\
\text { entre um aparente artelho } 4 \text { alargado; } \\
\text { clinodactilia do artelho } 5 \text { bilateral, atraso na } \\
\text { aquisição de fala; dificuldades de } \\
\text { aprendizagem; hiperatividade; ADNPM }\end{array}$ & $\begin{array}{l}\text { IMC: } 26 \mathrm{a} / \mathrm{IPC}: 30 \mathrm{a} \quad \mathrm{G} 1 \mathrm{P} 1 \mathrm{~A} 0 \\
\text { Sem intercorrências gestacionais } \\
\text { relevantes. } \\
\text { Parto cesáreo; gestação } 7 \text { meses. } \\
\mathrm{PN}=1.950 \mathrm{~g}(\mathrm{p}<3) \\
\mathrm{EN}=42 \mathrm{~cm}(\mathrm{p}<3) \\
\text { Internado } 10 \text { dias - dificuldades } \\
\text { alimentares. Aos } 16 \text { meses, realizou } \\
\text { cirurgia cardíaca e aos } 6 \text { anos de idade, } \\
\text { realizou adenoidectomia. }\end{array}$ & $\begin{array}{l}\text { Cariótipo: } 46, \mathrm{XX} \\
\text { Tomografia computadorizada, } \\
\text { ressonância magnética encéfalo e } \\
\text { uretrocistografia: normais } \\
\text { Ecografia renal: bexiga pequena } \\
\text { Erros inatos metabolismo: negativo } \\
\text { Ecocardiograma: CIV; estenose } \\
\text { infundibular do ventrículo D } \\
\text { Avaliação oftalmológica: estrabismo } \\
\text { convergente, hipermetropia e } \\
\text { astigmatismo } \\
\text { RX pés: sindactilia 1-2 e 3-4 artelhos } \\
\text { bilateral (parece haver fusão óssea } \\
\text { distal) } \\
\text { Estudo molecular: análise por PCR } \\
\text { através de } 5 \text { marcadores polimórficos } \\
\text { da região 22q11.2 (D22S1638, } \\
\text { D22S1648, D22S944, D22S1623, } \\
\text { D22S1709) mostrou deleção de pelo } \\
\text { menos 1 dos marcadores estudados } \\
\text { Avaliação audiológica:DA condutiva } \\
\text { leve à D }\end{array}$ & $\begin{array}{l}\text { Síndrome velocardiofacial } \\
\text { (Síndrome deleção 22q11.2) } \\
\text { (HAD) }\end{array}$ \\
\hline $82 *$ & M & $8 \mathrm{a} 2 \mathrm{~m}$ & $\begin{array}{l}\text { Narinas antevertidas; lábio inferior grosso; } \\
\text { deficiência auditiva; amelogênese; pele } \\
\text { seca; ictiose mãos e pés }\end{array}$ & $\begin{array}{l}\text { IMC: } 20 \mathrm{a} / \text { IPC: } 24 \mathrm{a} \quad \text { G3P2A1 } \\
\text { Infecção urinária no } 7^{\circ} \text { mês gestacional. } \\
\text { Parto normal; gestação a termo. } \\
\mathrm{PN}=3.025 \mathrm{~g}(10<\mathrm{p}<25) \\
\mathrm{EN}=48 \mathrm{~cm}(3<\mathrm{p}<10) \\
\text { Sem intercorrências perinatais. } \\
\text { Pai e mãe com pele seca. }\end{array}$ & $\begin{array}{l}\text { Cariótipo: } 46, \mathrm{XY} \\
\text { Ultrassom renal: normal } \\
\text { Avaliação audiológica:DA } \\
\text { sensorioneural profunda bilateral }\end{array}$ & $\begin{array}{l}\text { Síndrome de Heimler? } \\
\text { (HAR) }\end{array}$ \\
\hline
\end{tabular}



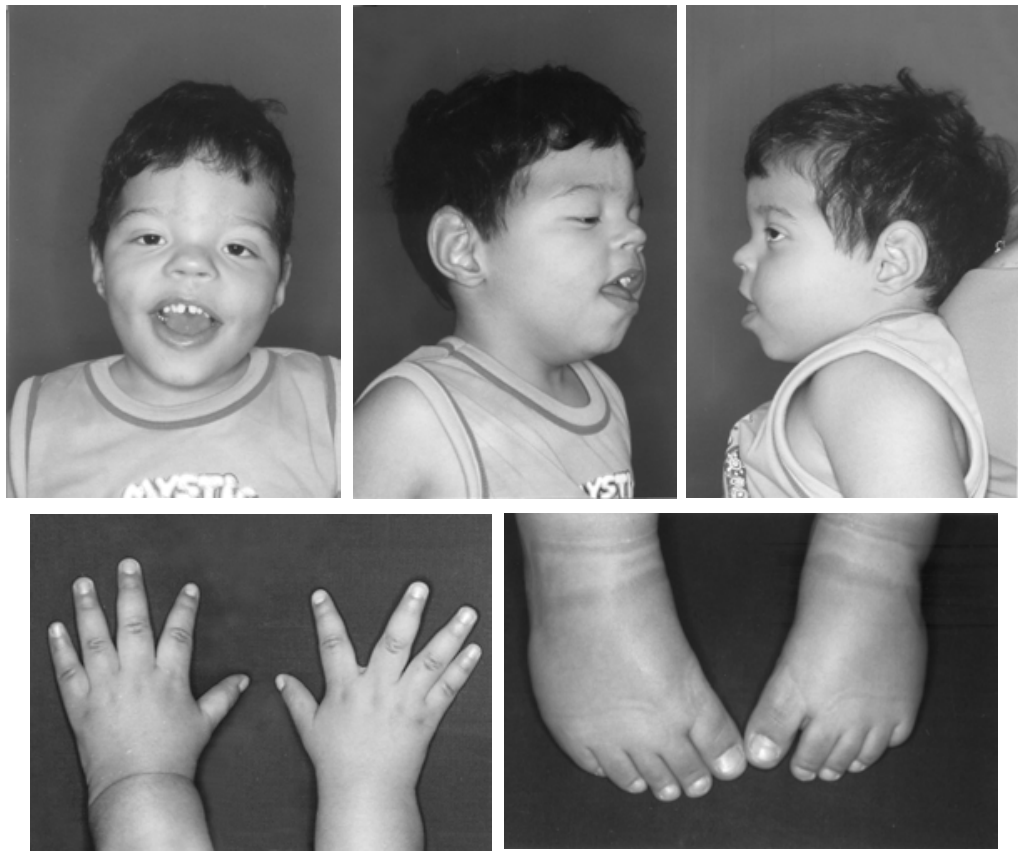

FIGURA 121: Aspectos clínicos do Caso 80
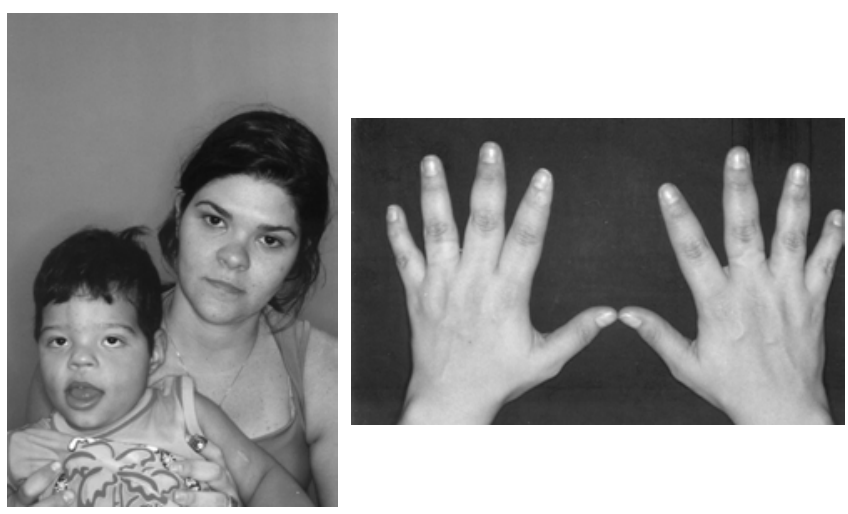

FIGURA 122: Aspectos clínicos da genitora do Caso 80

I

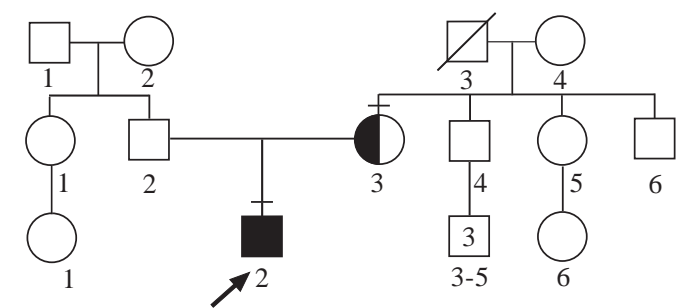

- Propósito

D Base nasal baixa e alargada; dígitos largos, curtos e hiperextensíveis; falanges distais afiladas; unhas convexas

FIGURA 123: Heredograma da família do Caso 80 

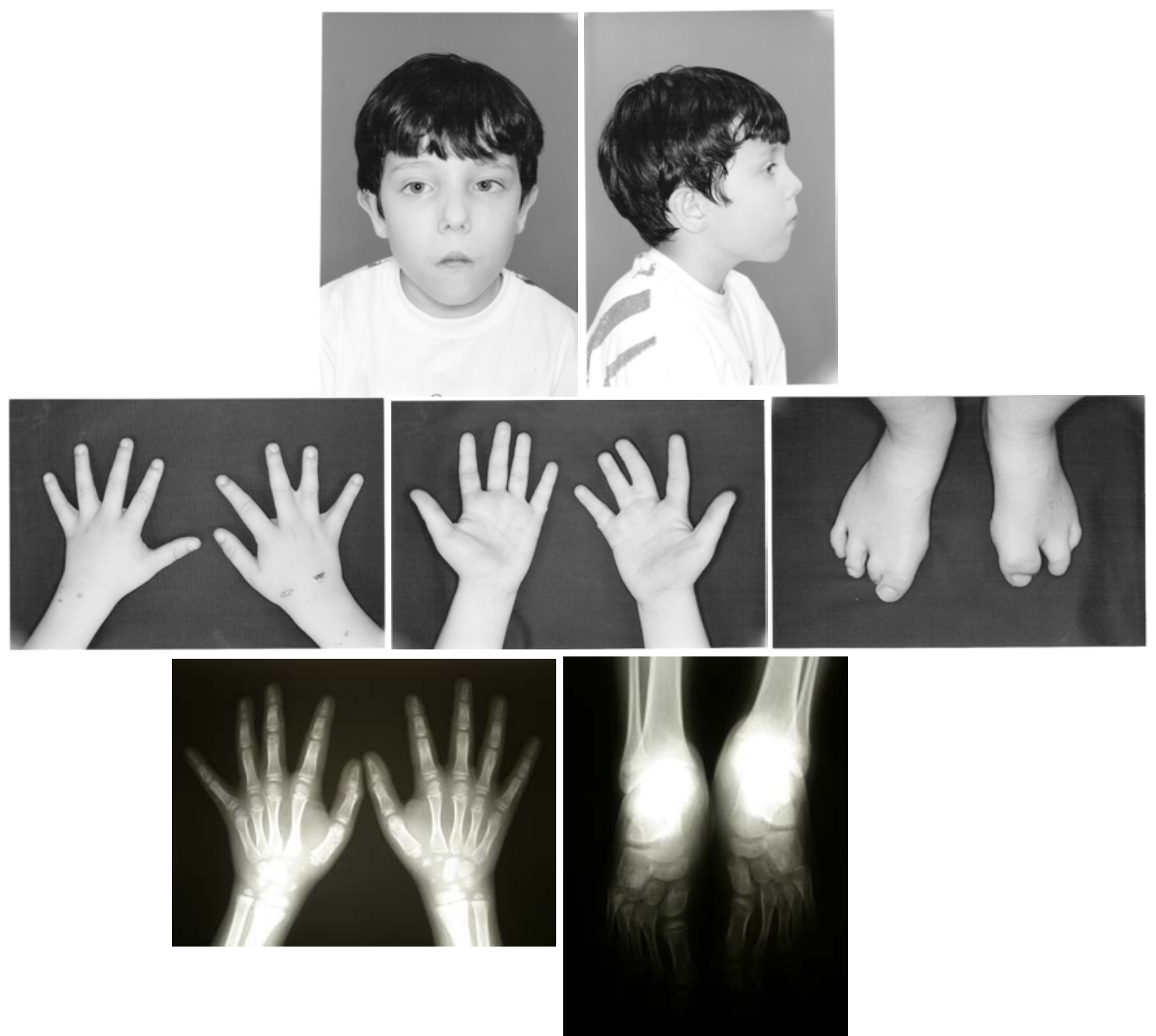

FIGURA 124: Aspectos clínicos e radiológicos do Caso 81 


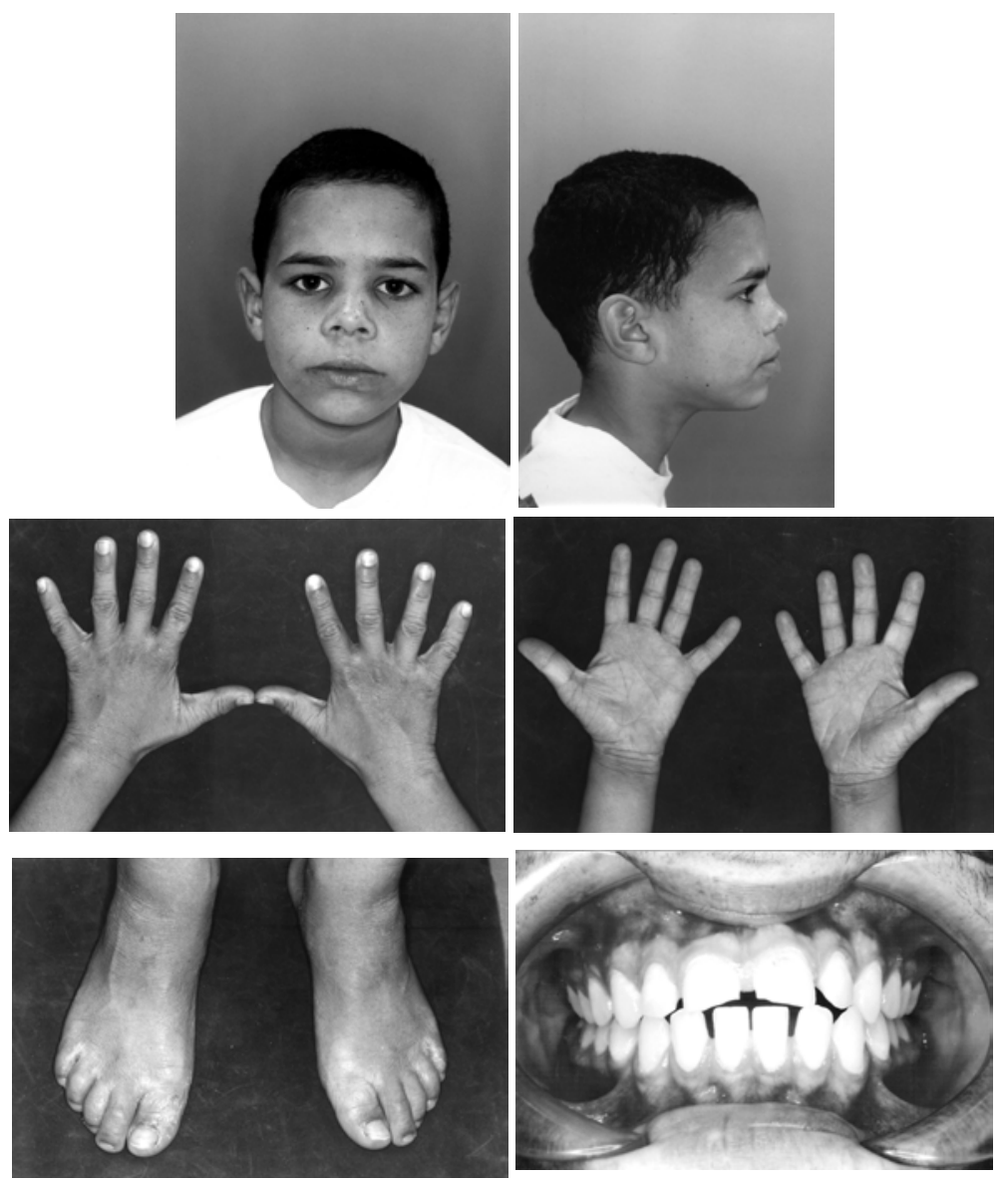

FIGURA 125: Aspectos clínicos do Caso 82 
Os dados referentes aos Casos 80 a 82 constam na Tabela 13.

O Caso 80 (Figuras 121 e 123; III-2), indivíduo do sexo masculino, apresentou fácies grosseiro incluindo frontal amplo, fendas palpebrais oblíquas para baixo, hipertelorismo ocular, boca grande e lábios grossos, característico da síndrome Coffin-Lowry (OMIM 303600). Essa é uma condição rara, ligada ao $\mathrm{X}$ dominante, na qual homens afetados apresentam atraso mental mais grave com dismorfismo característico, principalmente acometendo face e mãos. O fenótipo facial se acentua durante a infância e fase adulta e, as mãos são típicas e se mostram alargadas, com dígitos hiperextensíveis, curtos e grossos e com falanges distais afiladas. Cerca de $80 \%$ dos indivíduos com síndrome de Coffin-Lowry é esporádica e, mais de 75 diferentes mutações patogênicas, no gene $R S K 2$, foram identificadas em indivíduos com esse quadro (Hanauer e Young 2006). O Caso 80, além da aparência facial típica da síndrome de Coffin-Lowry, apresentou, ainda, padrão de mãos característico dessa condição. $\mathrm{O}$ atraso mental desse indivíduo era grave, assim como o observado nos indivíduos, do sexo masculino, com esse quadro. Perda auditiva sensorioneural, outro achado clínico, nem sempre é considerada parte do espectro da síndrome (Higashi e Matsuki 1994, Rosanowski et al 1998). Segundo Hunter (2002), a estimativa sobre a freqüência da perda auditiva é subestimada pela não avaliação sistemática dos indivíduos com o quadro, e este achado não seria uma ocorrência casual. A genitora do Caso 80 (Figura 123; II-3) apresentou base nasal baixa e alargada; dígitos largos, hiperextensíveis e afilados nas extremidades (Figura 122), manifestações essas, compatíveis com a forma leve da síndrome de Coffin-Lowry, observada nas mulheres afetadas.

O Caso 81 (Figura 124), da presente casuística, apresentou, dentre as principais manifestações clínicas, dismorfismo facial, fissura de palato submucosa, deficiência auditiva, cardiopatia congênita, atraso de aquisição de fala, dificuldades de aprendizagem e anomalia de membros. Considerando a sobreposição clínica, do quadro em questão, com a síndrome da deleção do 22q11.2, esta região foi analisada por PCR, através de marcadores polimórficos (D221638, D22S1648, D22S944, D22S1623, D22S1709), revelando deleção de, pelo menos, um marcador dessa região. Análise molecular dos genitores não mostrou deleção nessa região. A síndrome de deleção 22q11.2 é uma das desordens genéticas mais comuns em humanos, com prevalência estimada de, aproximadamente, 1:4.000 nativivos (Óskarsdóttir et al 2004). Características clínicas clássicas incluem defeito cardíaco congênito, insuficiência 
velofaringeana ou fissura de palato, anomalias faciais, dificuldades de aprendizagem, hipocalcemia neonatal e deficiência de células T (McDonald-McGinn et al 1999). A síndrome de deleção 22q11.2 abrange a síndrome velocardiofacial (OMIM 192430), a síndrome DiGeorge (OMIM 188400) e a síndrome da face e anomalia conotruncal (síndrome de Takao - OMIM 217095), todas decorrentes de deleções intersticiais no cromossomo 22q11.2 (Thomas e Graham 1997). Previamente, essas três síndromes foram consideradas condições distintas, mas, atualmente, acredita-se que elas representem variabilidade de expressão do mesmo defeito genético (Swillen et al 2000). $\mathrm{Na}$ maioria dos casos, a deleção intersticial no 22q11.2 ocorre de novo, mas pode ser herdada em $10 \%$ a $25 \%$ dos casos. Acentuada variabilidade na expressão clínica, tanto inter quanto intrafamilial, é característica dessa condição (Leana-Cox et al 1996, Ravnan et al 1996). Apesar dessa variabilidade, não há evidência de correlação fenótipo-genótipo (Lindsay 2001, Fernández et al 2005). Em relação ao Caso 81, o achado molecular o incluiu na síndrome deleção 22q11.2. A aparência facial e manifestações clínicas foram compatíveis com as dos indivíduos previamente relatados como tendo a síndrome velocardiofacial. Alterações de extremidades, presentes no Caso 81, são incomuns nessa condição. Poucos relatos mencionam anomalias esqueléticas em indivíduos com síndrome de deleção do 22q11.2 e, referem-se, principalmente, às anomalias de mãos (Wilson et al 1993, Cormier-Daire et al 1995, Shalev et al 1996, Prasad et al 1997, Kasprzak et al 1998). Anomalias esqueléticas envolvendo membros superiores e inferiores, costelas e/ou vértebras foram detectadas em 34\% dos 108 indivíduos avaliados por Ming et al (1997). Acometimento de mãos (polidactilia e sindactilia cutânea) e de pés (agenesia de raio 3, sindactilias) estavam presentes no Caso 81. Cabe, ainda, comentar que esse indivíduo apresentava deficiência auditiva condutiva. Este achado é observado em cerca de $45 \%$ a $75 \%$ dos indivíduos descritos com a síndrome velocardiofacial (Digilio et al 1999, Ford et al 2000). Segundo esses autores, esse tipo de perda é, muito provavelmente, decorrente de freqüentes otites médias serosas e da fissura de palato, freqüentes nessa população. Já, perda auditiva sensorioneural, segundo Gorlin et al (2001), ocorre em 8\% desses indivíduos.

O Caso 82 (Figura 125) apresentou deficiência auditiva sensorioneural, ictiose e amelogênese (na dentição permanente). Consangüinidade parental estava presente nesse indivíduo. Levantamento de literatura e busca em banco de dados (Gorlin et al 1995, OMIM 2006) mostrou concordância de achados clínicos com a síndrome de 
Heimler (OMIM 234580), condição rara e determinada por gene autossômico recessivo. Até o momento, quatro casos (três familiais e um isolado) foram relatados na literatura (Fox et al 1989, Heimler et al 1991, Tischkowitz et al 1999, Pollak et al 2003). Embora alterações ungueais (linhas de Beau, leuconíquia) sejam citadas na maioria dos casos relatados e estejam ausentes no Caso 82, as demais manifestações clínicas e a presença de consangüinidade parental, direcionam para o diagnóstico de síndrome de Heimler. Por tratar-se de condição em fase inicial de delineamento, a adição de novos casos contribuirá com o conhecimento do fenótipo. 


\subsection{Categoria II: síndromes de etiologia ambiental (Casos 83 a 87)}

Nesse grupo foram incluídos 5 indivíduos com deficiência auditiva e múltiplas anomalias, de etiologia ambiental. Síndrome da rubéola congênita foi considerada como fator etiológico para o Caso 83; síndrome alcoólica fetal para o Caso 84; embriopatia diabética para o caso 85 e, múltiplas malformações de etiologia ambiental para os Casos 86 e 87. Nesse grupo, observou-se 2 casos com deficiência auditiva sensorioneural, 1 caso com deficiência auditiva condutiva, 1 caso com deficiência auditiva mista e outro com perda auditiva condutiva e sensorioneural. Dados referentes a esse grupo foram apresentados na Tabela 14 . 
TABELA 14: Dados dos indivíduos com síndrome de etiologia ambiental

\begin{tabular}{|c|c|c|c|c|c|c|}
\hline Indivíduo & Sexo & Idade & Sinais clínicos & $\begin{array}{l}\text { Dados gestacionais e perinatais/ } \\
\text { antecedentes pessoais e familiais }\end{array}$ & $\begin{array}{l}\text { Exames complementares e } \\
\text { caracterização da DA }\end{array}$ & Hipótese diagnóstica \\
\hline 83 & $\mathrm{~F}$ & $3 \mathrm{~m}$ & $\begin{array}{l}\text { Microcefalia; catarata congênita à } \mathrm{D} \text {; } \\
\text { microftalmia à } \mathrm{D} ; \text { deficiência auditiva; } \\
\text { cardiopatia congênita; ADNPM }\end{array}$ & $\begin{array}{l}\text { IMC: } 23 \mathrm{a} \text { / IPC: } 39 \mathrm{a} \quad \text { G5P4A1 } \\
\text { Rubéola no } 1^{\circ} \text { mês gestacional.No } 5^{\circ} \\
\text { mês, diagnosticou-se oligoidrâmnio. } \\
\text { Parto cesáreo; gestação } 38 \text { semanas. } \\
\text { PN=2.300g (p=3) } \\
\mathrm{EN}=\text { ? } \\
\text { Nasceu cianótica.Permaneceu } 6 \text { dias } \\
\text { internada. } \\
\text { Realizou cirurgia cardíaca aos } 45 \text { dias de } \\
\text { vida e de catarata, aos } 2 \text { meses. } \\
\text { Aos } 5 \mathrm{a} 3 \mathrm{~m} \text { idade: } \mathrm{PC}=46.5 \mathrm{~cm}(\mathrm{p}<2)\end{array}$ & $\begin{array}{l}\text { Cariótipo: } 46, X X \\
\text { Tomografia computadorizada crânio- } \\
\text { encefálica: pequena lacuna na } \\
\text { profundidade do hemisfério } \\
\text { cerebral D, de aspecto sequelar; } \\
\text { discreto alargamento dos espaços } \\
\text { liquóricos em torno dos lobos frontais } \\
\text { e temporais. } \\
\text { Avaliação cardiológica: PCA; } \\
\text { coarctação da aorta } \\
\text { Avaliação oftalmológica: alta } \\
\text { hipermetropia bilateral; microftalmia e } \\
\text { catarata congênita à D } \\
\text { Avaliação audiológica:DA } \\
\text { sensorioneural profunda bilateral }\end{array}$ & $\begin{array}{l}\text { Síndrome da } \\
\text { rubéola congênita }\end{array}$ \\
\hline 84 & M & $10 \mathrm{a} 5 \mathrm{~m}$ & $\begin{array}{l}\text { Baixa estatura; microcefalia; hipoplasia } \\
\text { malar; fendas palpebrais estreitas; filtro } \\
\text { longo; fissura de palato; orelhas } \\
\text { proeminentes; atresia do canal auditivo } \\
\text { externo à D; deficiência auditiva; } \\
\text { braquidactilia e hipoplasia ungueal do } 5^{\circ} \\
\text { dígito bilateral (mais acentuada à E); } \\
\text { hipoplasia ungueal do } 3^{\circ}, 4^{\circ} \text { e } 5^{\circ} \text { artelhos } \\
\text { bilateral; hipospadia; dificuldades escolares; } \\
\text { ADNPM }\end{array}$ & 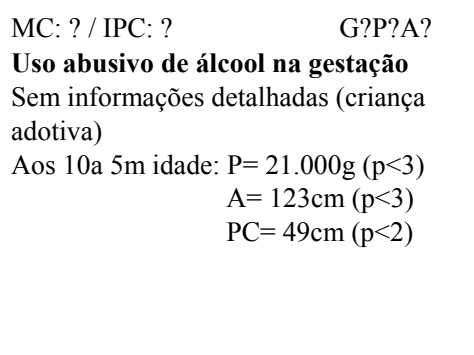 & $\begin{array}{l}\text { Cariótipo: } 46, X Y \\
\text { Avaliação audiológica:DA condutiva } \\
\text { moderada bilateral }\end{array}$ & $\begin{array}{l}\text { Síndrome } \\
\text { alcoólica fetal }\end{array}$ \\
\hline
\end{tabular}


Continuação TABELA 14: Dados dos indivíduos com síndrome de etiologia ambiental

\begin{tabular}{|c|c|c|c|c|c|c|}
\hline Indivíduo & Sexo & Idade & Sinais clínicos & $\begin{array}{l}\text { Dados gestacionais e perinatais/ } \\
\text { antecedentes pessoais e familiais }\end{array}$ & $\begin{array}{l}\text { Exames complementares e } \\
\text { caracterização da DA }\end{array}$ & Hipótese diagnóstica \\
\hline 85 & M & $5 \mathrm{a} 4 \mathrm{~m}$ & $\begin{array}{l}\text { Baixa estatura; déficit ponderal; microcefalia; } \\
\text { assimetria facial; hipoplasia malar; paralisia } \\
\text { hemifacial D; base nasal larga; fendas } \\
\text { palpebrais estreitas; epicanto bilateral; } \\
\text { discreto estrabismo divergente; micrognatia; } \\
\text { orelhas proeminentes; atresia CAE bilateral; } \\
\text { deficiência auditiva pregas cutâneas } \\
\text { interdigitais bilateral; pregas palmares } \\
\text { anômalasbilateral; camptodactilia3 }{ }^{\circ} \text { dígito à } \\
\text { D; hipoplasia polegar D com desvio radial; } \\
\text { hipoplasia tenar e hipotenar bilateral; hérnia } \\
\text { inguinal bilateral; hipoplasia de sacro; } \\
\text { agenesia de cóccix. }\end{array}$ & $\begin{array}{l}\text {; IMC: } 28 \mathrm{a} \text { / IPC: } 35 \mathrm{a} \quad \text { G4P2A2 } \\
\text { Mãe diabética, insulino-dependente } \\
\text { Parto cesáreo; gestação } 38 \text { semanas. } \\
\mathrm{PN}=3.200 \mathrm{~g}(\mathrm{p}=50) \\
\mathrm{EN}=51 \mathrm{~cm}(50<\mathrm{p}<75) \\
\text { Nasceu com hipoglicemia. Internado } 7 \\
\text { dias. } \\
\text { Herniorrafia aos } 2 \text { anos de idade. } \\
\text { Aos } 8 \mathrm{a} 11 \mathrm{~m} \text { idade: } \mathrm{P}=19.100 \mathrm{~g}(\mathrm{p}<3) \\
\qquad \mathrm{A}=117 \mathrm{~cm}(\mathrm{p}<3)\end{array}$ & $\begin{array}{l}\text { Cariótipo: } 46, X Y \\
\text { Tomografia computadorizada crânio- } \\
\text { encefálica, ressonância nuclear } \\
\text { magnética, ultrassom renal, ultrassom } \\
\text { abdômen total: normais. } \\
\text { RX tórax, antebraços e mão E: } \\
\text { normais. } \\
\text { RX mão D: deformidade anatômica da } \\
\text { articulação interfalangeana média do } \\
3^{\circ} \text { dígito. } \\
\text { Cistometria miccional: bexiga } \\
\text { neurogênica de pequena capacidade e } \\
\text { hiperreflexa. } \\
\text { RX uretrocistografia: hipoplasia do } \\
\text { sacro com agenesia do cóccix. } \\
\text { Avaliação audiológicaDA condutiva } \\
\text { moderada à D e DA sensorioneural } \\
\text { profunda à E }\end{array}$ & Embriopatia diabética \\
\hline
\end{tabular}


Continuação TABELA 14: Dados dos indivíduos com síndrome de etiologia ambiental

\begin{tabular}{|c|c|c|c|c|c|c|}
\hline Indivíduo & Sexo & Idade & Sinais clínicos & $\begin{array}{l}\text { Dados gestacionais e perinatais/ } \\
\text { antecedentes pessoais e familiais }\end{array}$ & $\begin{array}{l}\text { Exames complementares e } \\
\text { caracterização da DA }\end{array}$ & Hipótese diagnóstica \\
\hline 86 & M & $9 a$ & $\begin{array}{l}\text { Déficit ponderal; microcefalia; discreta } \\
\text { assimetria de face; fácies triangular; nariz } \\
\text { alongado; atresia de coanas; ectropio; filtro } \\
\text { curto; boca grande; hipotonia bucal; } \\
\text { retrognatia; orelhas proeminentes, } \\
\text { posteriorizadas e com baixa implantação; } \\
\text { anti-hélices anômalos; lóbulos hipoplásicos; } \\
\text { deficiência auditiva; refluxo gastro- } \\
\text { esofágico; ADNPM }\end{array}$ & $\begin{array}{l}\text { IMC: } 28 \mathrm{a} \text { / IPC: } 31 \mathrm{a} \text { G4P4A0 } \\
\text { Durante toda a gestação, mãe teve contato } \\
\text { direto com agrotóxicos. No } 1^{\circ} \text { trimestre, } \\
\text { apresentou quadro de irritação de pele, que } \\
\text { evoluiu com formação de lesões no nariz, } \\
\text { lábios e dorso das mãos. Outros sintomas } \\
\text { apresentados pela mãe, no decorrer da } \\
\text { gestação, foram tontura e falta de ar.. } \\
\text { Parto normal ; gestação de } 7 \text { meses } \\
\text { PN=2.200g (p=10) } \\
\text { EN=? } \\
\text { Não chorou ao nascimento. Desenvolveu } \\
\text { quadro de insuficiência respiratória grave. } \\
\text { Internado durante } 3 \text { meses quando foi } \\
\text { comprovada intoxicação por clorado. } \\
\text { Realizou cirurgia gastro-esofágica aos } 5 \mathrm{a} \\
\text { de idade. } \\
\text { Aos } 10 \mathrm{a} 10 \mathrm{~m} \text { idade: } \mathrm{P}=22.000 \mathrm{~g}(\mathrm{p}<3) \\
\qquad \mathrm{PC}=47 \mathrm{~cm}(\mathrm{p}<2)\end{array}$ & $\begin{array}{l}\text { Cariótipo: } 46, X Y \\
\text { Ecocardiograma: normal } \\
\text { Avaliação oftalmológica: normal } \\
\text { Ultrassonografia renal: normal } \\
\text { TORCH: negativo } \\
\text { EED e deglutograma: incoordenação } \\
\text { crico-faríngea } \\
\text { com acentuado refluxo; } \\
\text { compressão do arco duodenal } \\
\text { Avaliação audiológica:DA mista } \\
\text { moderada bilateral }\end{array}$ & $\begin{array}{l}\text { Múltiplas malformações de } \\
\text { etiologia ambiental }\end{array}$ \\
\hline
\end{tabular}


Continuação TABELA 14: Dados dos indivíduos com síndrome de etiologia ambiental

\begin{tabular}{|c|c|c|c|c|c|c|}
\hline Indivíduo & Sexo & Idade & Sinais clínicos & $\begin{array}{l}\text { Dados gestacionais e perinatais/ } \\
\text { antecedentes pessoais e familiais }\end{array}$ & $\begin{array}{l}\text { Exames complementares e } \\
\text { caracterização da DA }\end{array}$ & Hipótese diagnóstica \\
\hline 87 & M & $7 \mathrm{a} 2 \mathrm{~m}$ & $\begin{array}{l}\text { Micro-braquicefalia; sobrancelhas anômalas; } \\
\text { olhos pequenos; orelhas proeminentes; anti- } \\
\text { hélices simplificados; deficiência auditiva; } \\
\text { hipertelorismo mamário; politelia à D; } \\
\text { oligodactilia de mãos com agenesia ungueal; } \\
\text { agenesia total de artelhos; pele seca; RNM }\end{array}$ & $\begin{array}{l}\text { IMC: } 29 \mathrm{a} / \text { IPC: } 30 \mathrm{a} \quad \text { G4P4A0 } \\
\text { Hipertensão arterial a partir do } 2^{\circ} \text { mês } \\
\text { gestacional (uso de hipotensor); perda de } \\
\text { líquido amniótico. } \\
\text { Parto cesáreo; gestação de } 27 \text { semanas } \\
\text { PN= 800g (p<3) } \\
\text { EN=? } \\
\text { Permanência em incubadora por } \mathbf{5 6} \text { dias. } \\
\text { Aos } 11 \text { a } 7 \mathrm{~m}: \mathrm{PC}=49.5 \mathrm{~cm}(p<2)\end{array}$ & $\begin{array}{l}\text { Cariótipo: 46,XY } \\
\text { Avaliação radiológica: } \\
\text { Mãos - ossos do carpo atípicos, } \\
\text { bilateralmente. Presença de } 3 \\
\text { metacarpianos anormalmente } \\
\text { modelados, bilateralmente, e agenesia } \\
\text { dos metacarpeanos } 4 \text { e } 5 \text {, } \\
\text { bilateralmente. Complemento } \\
\text { trifalângico à D correspondente ao } \\
\text { dedo } 3 \text { bilateralmente e, à E um } \\
\text { complemento às custas da falange } \\
\text { proximal, correspondente ao } \\
\text { metacarpeano } 2 \text {. } \\
\text { Pés - Fusão bilateral do calcâneo e } \\
\text { astrágano; agenesia das estruturas } \\
\text { distais a partir do metatarso. } \\
\text { Tomografia computadorizada crânio- } \\
\text { encefálica: normal } \\
\text { Ecografia renal: normal } \\
\text { Avaliação audiológica: DA } \\
\text { sensorioneural profunda bilateral }\end{array}$ & $\begin{array}{l}\text { Múltiplas malformações de } \\
\text { etiologia ambiental }\end{array}$ \\
\hline
\end{tabular}



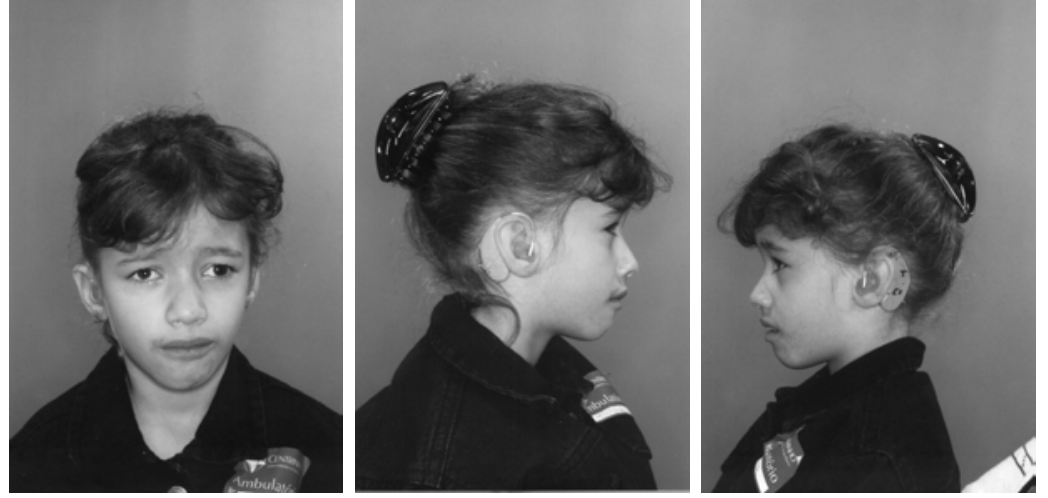

FIGURA 126: Aspectos clínicos do Caso 83

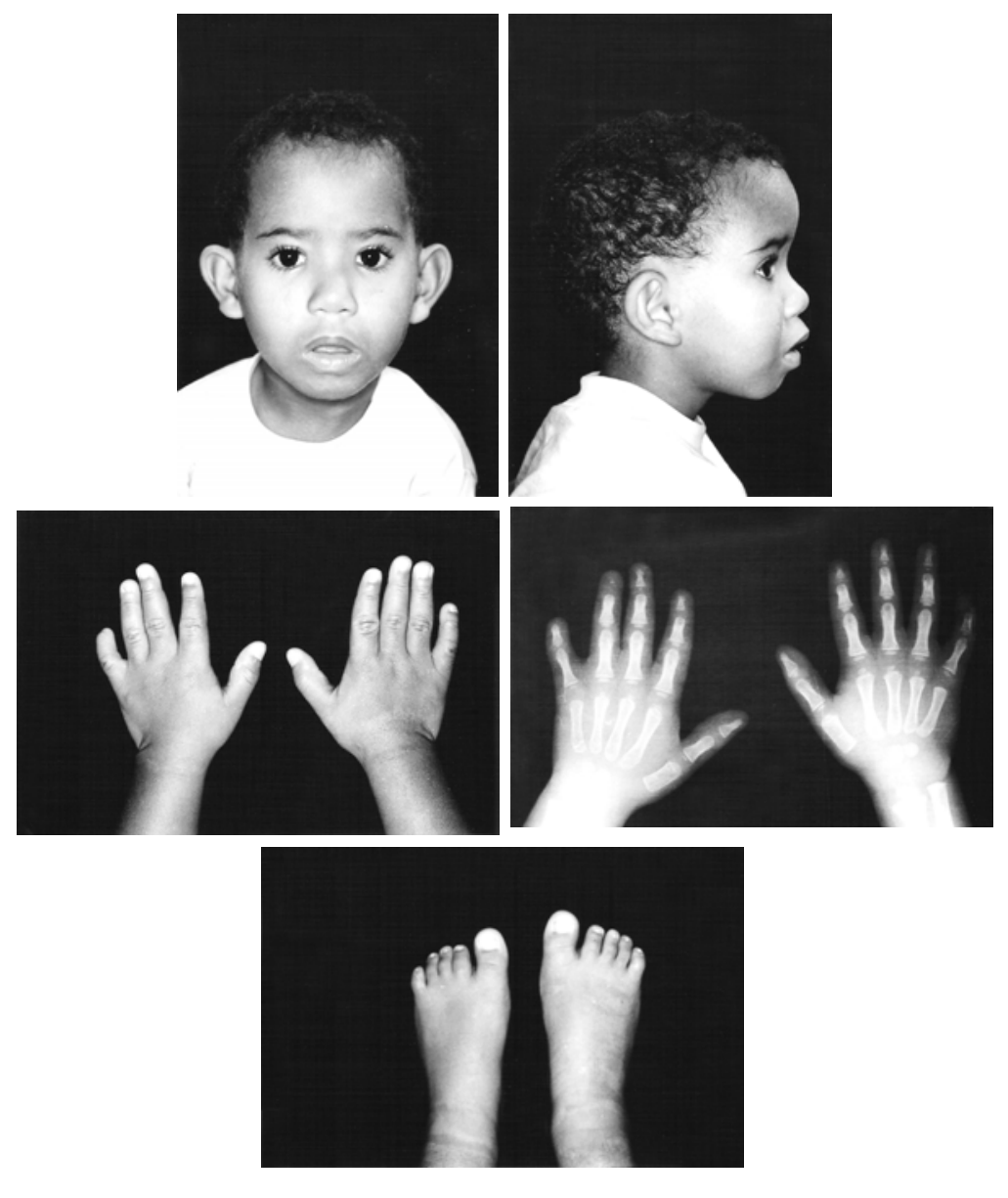

FIGURA 127: Aspectos clínicos do Caso 84 

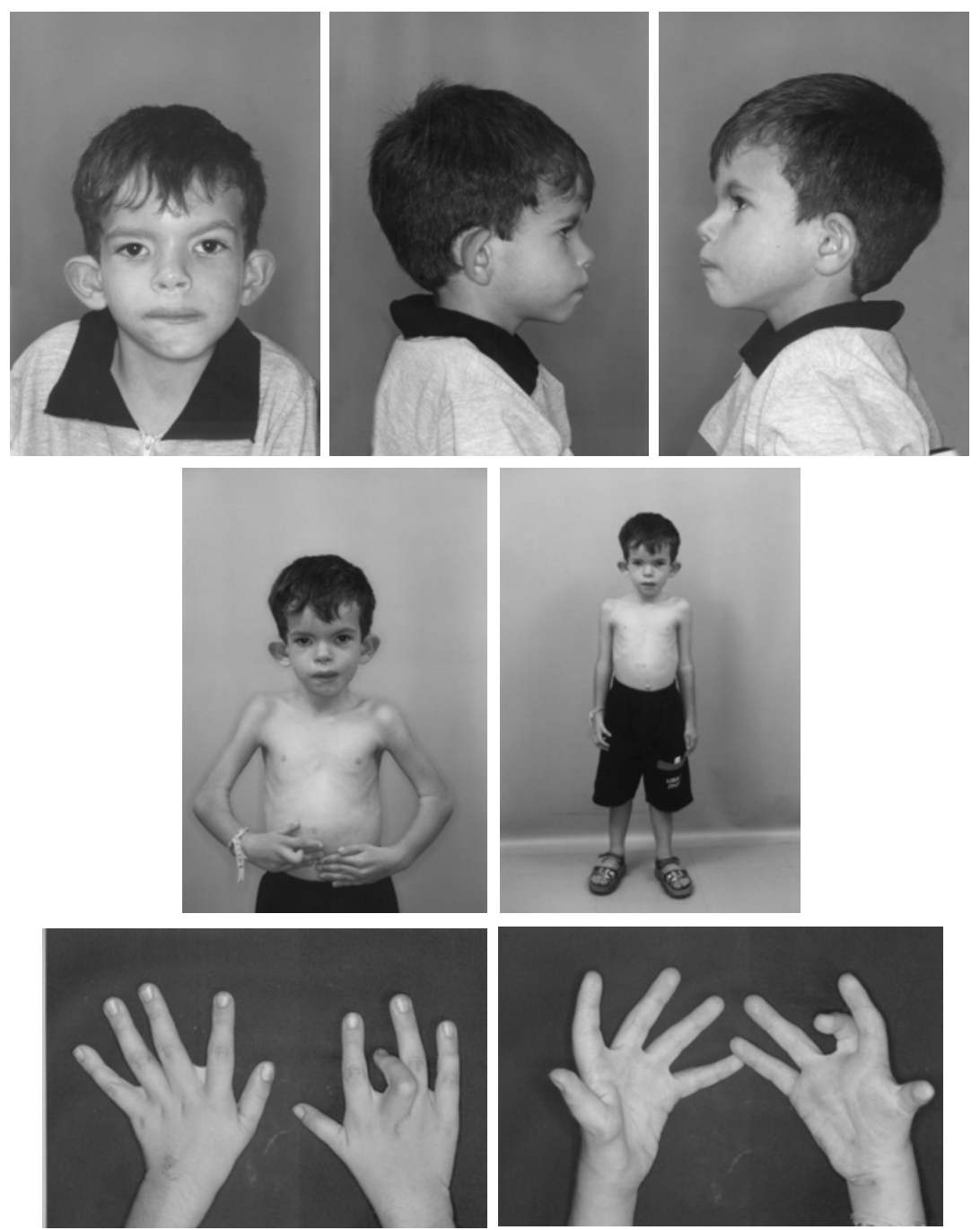

FIGURA 128: Achados clínicos do Caso 85 

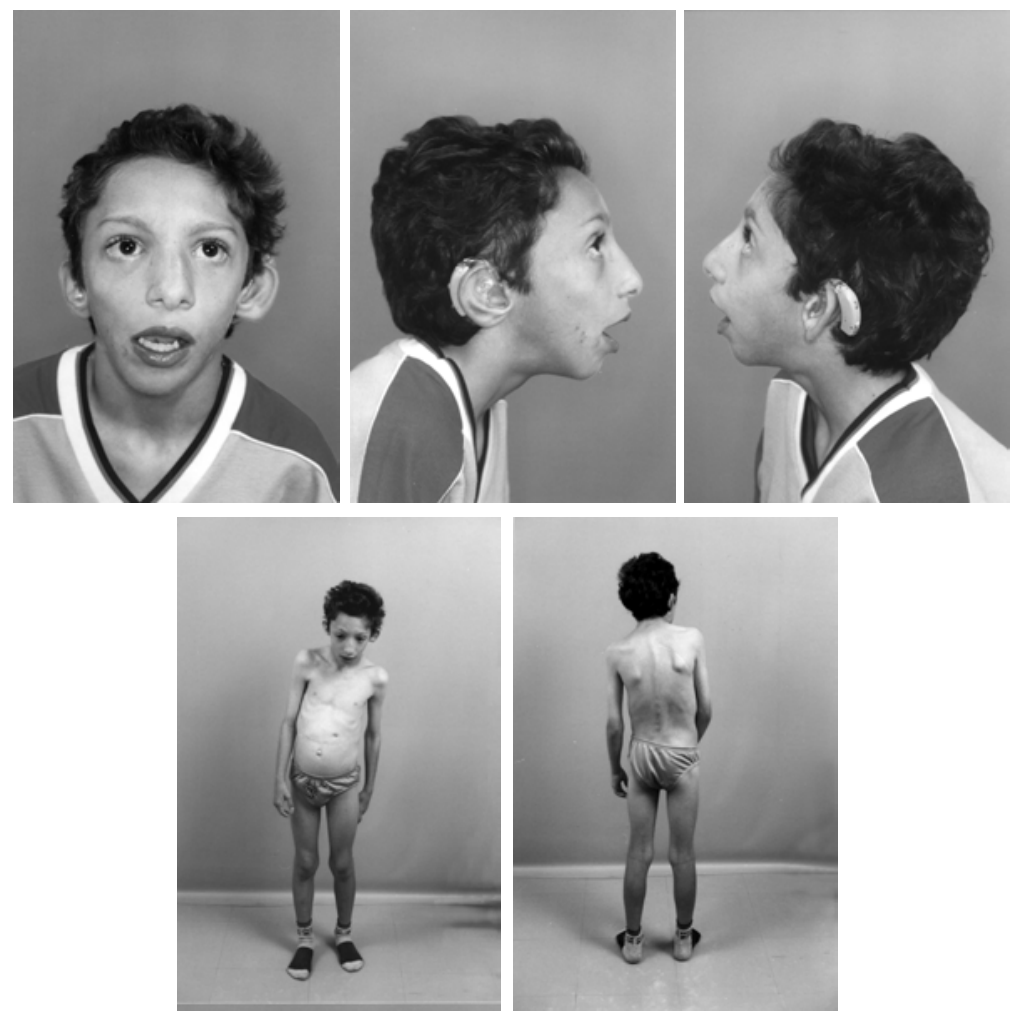

FIGURA 129: Achados clínicos do Caso 86 

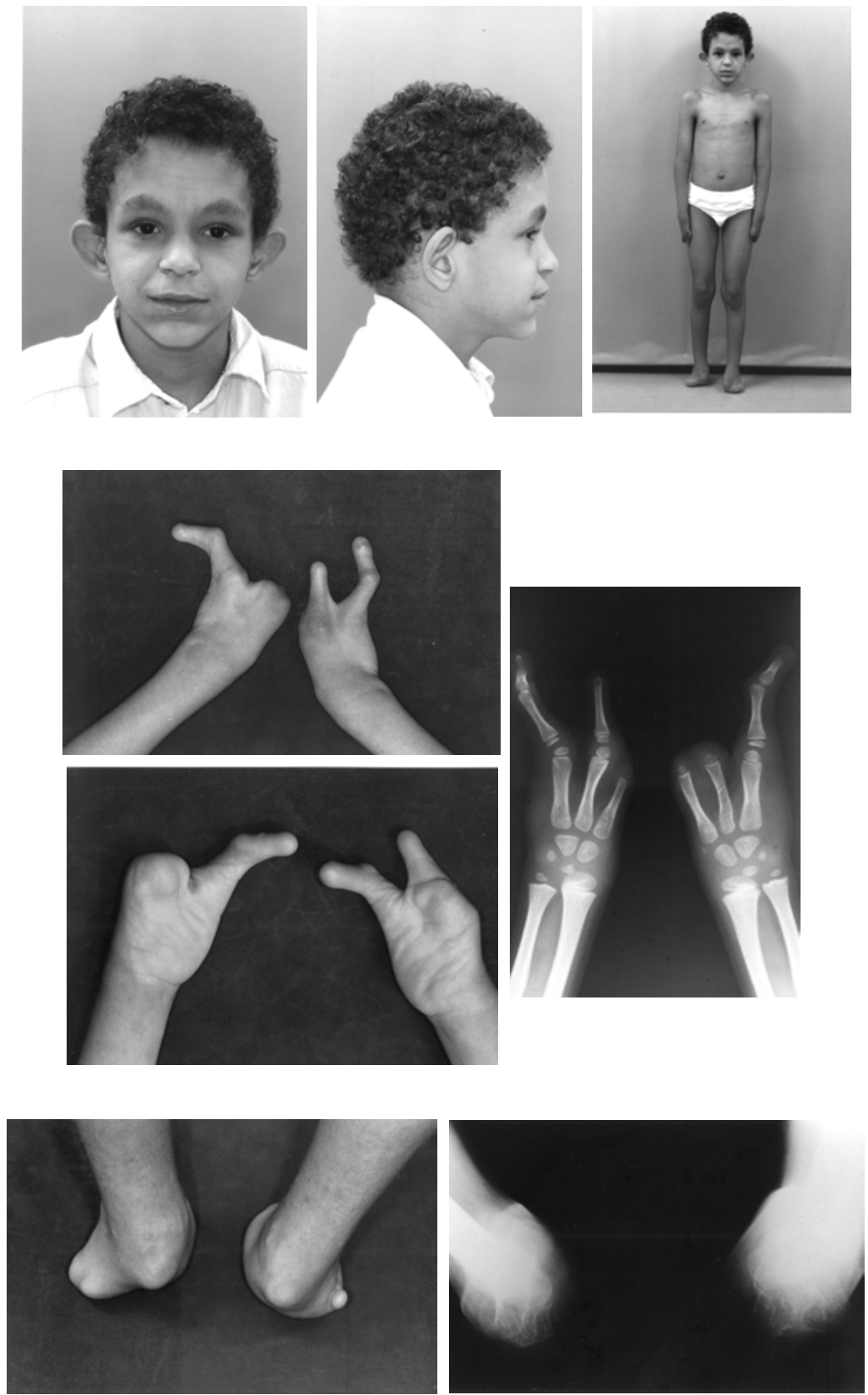

FIGURA 130: Achados clínicos e radiológicos do Caso 87 
Diversos são os fatores ambientais que podem estar associados às anomalias congênitas. Estes fatores variam desde infecções maternas, teratógenos químicos, agentes físicos e mecânicos, até fatores nutricionais. De forma geral, os fatores ambientais são, particularmente, nocivos no primeiro trimestre da gestação. A exposição ao mesmo teratógeno, em diferentes momentos da gestação, pode produzir diferentes anomalias de diferentes graus de acometimento e, a susceptibilidade a esse agente depende do genótipo do concepto (Cohen Jr 1997). Na presente casuística, os Casos 83, 84, 85, 86 e 87 (Tabela 14) apresentaram comprometimento fenotípico associado à deficiência auditiva decorrentes da influência de fatores ambientais (rubéola, álcool, diabetes materno, agrotóxico, meningite).

$\mathrm{O}$ vírus da rubéola foi o primeiro a ser reconhecido como teratogênico e, a doença pode se apresentar sob a forma congênita ou adquirida. Em relação à forma congênita, a infecção por esse vírus ocorre por via transplacentária, podendo acometer $80 \%$ dos recém-nascidos, quando contraída durante as primeiras doze semanas de gestação, $54 \%$ na décima terceira a décima quarta semanas e $25 \%$ no final do segundo trimestre gestacional, sendo mais raro o acometimento após a vigésima semana (Miller et al 1982). As conseqüências dessa infecção congênita variam desde aborto espontâneo ou ocorrência de natimorto, até malformações múltiplas. A tríade clássica da síndrome da rubéola congênita caracteriza-se por anomalias cardíacas, catarata e deficiência auditiva sensorioneural. Outras alterações incluem atraso de crescimento pré e pósnatal, microftalmia, retinopatia, glaucoma, pneumopatia intersticial, hepatoesplenomegalia, trombocitopenia com púrpura, adenopatia, radiopacificações ósseas, encefalite, e atraso mental (Elango 1993). Formas menos comprometidas do quadro podem ocorrer somente com manifestação da deficiência auditiva ou de pequenas alterações cardíacas ou, ainda, de atraso mental leve (Chakravarti e Jain 2006). A gravidade do quadro está relacionada com a época da infecção materna; quanto mais precoce, maior número de órgãos serão comprometidos, levando a danos graves e, muitas vezes, incompatíveis com o desenvolvimento adequado desses indivíduos (Elango 1993). O Caso 83 (Tabela 14; Figura 126), da presente casuística, apresentou microcefalia, catarata, microftalmia, deficiência auditiva sensorioneural, persistência do canal arterial (PCA), coarctação da aorta e atraso no desenvolvimento neuropsicomotor. Antecedente gestacional de infecção por rubéola, no primeiro mês 
gestacional, foi clinicamente confirmado. A deficiência auditiva sensorioneural, um dos sinais cardinais da síndrome da rubéola congênita, acomete mais de $80 \%$ dos indivíduos com esse quadro (Grellet et al 1995). É possível que os casos de deficiência auditiva, por rubéola congênita, tenham uma base genética, já que há um aumento na incidência de perda auditiva sensorioneural, por essa causa, em famílias com uma predisposição genética à deficiência auditiva sensorioneural. A hipótese é que a predisposição à deficiência auditiva seja aumentada na presença de ambos os fatores etiológicos (Bluestone e Stool 1990).

Exposição ao álcool, no período pré-natal, pode resultar em efeitos adversos ao embrião/feto podendo levar a abortos, indivíduos natimortos ou, ainda, indivíduos com síndrome alcoólica fetal. A gravidade das manifestações depende de vários fatores, tais como, o tempo de exposição, o consumo pela genitora, o genótipo do indivíduo e outros fatores que possam exercer influência no desenvolvimento do feto (Strömland e PinazoDurán 2002). O álcool é, reconhecidamente, o maior responsável pelo atraso de crescimento e mental em crianças. Seus efeitos sobre o feto variam desde leve com achados dismorfológicos discretos até quadro com grave comprometimento, conhecido como síndrome alcoólica fetal. Essa é caracterizada, principalmente, pelo padrão de anomalias menores de face (hipoplasia malar, fendas palpebrais estreitas, epicanto, filtro longo), atraso de crescimento pré e pós-natal e comprometimento neurológico (hiperatividade, dificuldades de aprendizagem, distúrbio de linguagem, atraso mental). Outras manifestações clínicas como baixa estatura, hirsutismo, anomalias oculares, fissura de palato, deficiência auditiva, alterações esqueléticas, hipospadia, entre outras, foram observadas em indivíduos com essa condição (Gorlin et al 2001). Padrão facial característico, microcefalia, deficiência auditiva condutiva, atraso global do desenvolvimento, entre outros achados fenotípicos, e, ainda, antecedente gestacional de álcool, conferem ao Caso 84 (Tabela 14; Figura 127), da presente casuística, o diagnóstico da síndrome fetal alcoólica. Deficiência auditiva condutiva, observada nesse caso, é comum nos indivíduos com essa síndrome. A alta incidência desse tipo de perda auditiva (77\%), nos indivíduos com esse quadro, está relacionada à alta prevalência de otite média nessa população (Church e Gerkin 1988, Church et al 1997). Church e Abel (1998) comentam que, pelo menos outros três tipos de desordens auditivas resultam da exposição ao álcool: atraso na maturação do sistema auditivo, perda auditiva 
sensorioneural e perda auditiva central. A sobreposição clínica entre a síndrome alcoólica fetal e a síndrome Coffin-Siris (OMIM 135900) é acentuada; porém, os antecedentes gestacionais de exposição ao álcool são relevantes na diferenciação.

A associação de diabetes materno (pré-gestacional) com anomalias congênitas é bem conhecida. A incidência dessas anomalias varia de $3 \%$ a $9 \%$, duas a três vezes mais freqüente que a observada na população geral (Martinez-Frias 1994, Herrera et al 2005). Esse risco aumentado, para mães diabéticas, pode resultar em abortos espontâneos ou em indivíduos com múltiplas anomalias (Grix Jr 1982). Os filhos de mães insulino-dependentes têm um risco ainda maior para malformações, especialmente para anomalias maiores e acometimento de vários órgãos e sistemas (Fuhrmann et al 1983, Becerra et al 1990). São comprometidos, com maior freqüência, os sistemas cardiovascular, nervoso central, geniturinário e esquelético. Estudos também mostram que filhos de mães com diabetes gestacional, especialmente aquelas com hiperglicemia, tem incidência mais alta de anomalias congênitas (Schaefer et al 2002). As anomalias decorrentes de diabetes materno são extremamente heterogêneas e sua patogênese não está, ainda, totalmente esclarecida (Herrera et al 2005). Em estudo epidemiológico realizado por Becerra et al (1990), verificou-se que, aparentemente, não existe um padrão particular de anomalias congênitas associadas ao diabetes gestacional ou materno, exceção feita à regressão caudal. Trabalho realizado mostrou que a regressão caudal (agenesia de sacro, malformações do trato geniturinário, malformações vertebrais e de membros inferiores) foi muito mais freqüente em filhos de mães diabéticas, do que na população geral (Mills 1982). Regressão caudal (hipoplasia de sacro e agenesia de cóccix) foi observada no Caso 85 (Tabela 14; Figura 128), da presente casuística. Esse indivíduo, filho de mãe diabética insulino-dependente apresentou, ainda, assimetria facial com paralisia hemifacial à direita, atresia de canal auditivo externo bilateral, deficiência auditiva condutiva à direita e sensorioneural à esquerda, hipoplasia de raio 1 e camptodactilia de dígitos. Além da regressão caudal, outras alterações esqueléticas, menos freqüentes, são observadas na embriopatia diabética, podendo envolver costelas, membros superiores e inferiores. Hipoplasia de raio 1 e camptodactilia, presente no Caso 85, foram previamente relatados por vários autores (Grix 1982, Ribeiro et al 1997). O diabetes materno tem, ainda, sido considerado como fator de risco para perda auditiva (Kountakis et al 2002). Anomalias 
de orelha, relacionadas ou não ao espectro oculoauriculovertebral têm sido associado ao diabetes materno e, nessas situações, a perda auditiva é freqüente (Grix Jr. 1982, Ribeiro et al 1997, Wang et al 2002). O Caso 85, da presente casuística, tinha atresia do canal auditivo externo e perda auditiva condutiva e sensorioneural. Embora alguns achados clínicos desse caso como: assimetria facial, paralisia hemifacial, anomalias de orelhas e perda auditiva, pertençam ao espectro oculoauriculovertebral, seu padrão facial difere do daqueles com essa condição. Cabe salientar que espectro oculoauriculovertebral e anomalias de raio 1, associado ao diabetes materno, foi referido por Ewart-Toland et al (2000).

Os agrotóxicos, comumente utilizados na agricultura, são, basicamente, divididos entre organofosfatos, ésteres de carbamato e compostos clorados. Muitos deles apresentaram potencial teratogênico em animais de laboratório, induzindo várias anormalidades estruturais, tais como anomalias cerebrais e esqueléticas. Vários estudos, em humanos, apontam para o fato de que a exposição ocupacional a esses agentes pode aumentar o risco de abortos espontâneos, defeitos de tubo neural, anomalias do sistema nervoso central, fissuras orofaciais, malformações cardiovasculares, urogenitais, músculo-esqueléticas, tegumentares (Nurminen et al 1995, Garry et al 1996, Kristensen et al 1997, Shaw et al 1999, Hanke e Hausman 2000). É de consenso que, na ausência de sinais de toxicidade materna, a exposição a agrotóxicos não cause danos para o embrião/feto. Antecedente gestacional de exposição materna a organoclorados e fungicidas (Captan e Benlate) com manifestações clínicas (quadro de irritação de pele com prurido e lesões em nariz, lábios e dorso das mãos), no primeiro trimestre e, ainda, evidências laboratoriais de intoxicação por organoclorados foram contundentes no Caso 86 (Tabela 14; Figura 129), da presente casuística. Prematuridade, atraso de crescimento e de desenvolvimento e quadro de dismorfia (microcefalia, fácies triangular, nariz alongado, atresia de coanas, filtro curto, boca grande, retrognatia, refluxo gastroesofágico, orelhas proeminentes com anti-hélices anômalos, hipoplasia de lóbulos), além de deficiência auditiva mista, foram observados no caso em questão. Embora, na literatura pertinente, não haja evidência epidemiológica que correlacionem um determinado tipo de agrotóxico com um padrão específico de malformações, muito provavelmente, as alterações observadas no Caso 86, sejam seqüelas diretas da exposição ao pesticida. $\mathrm{O}$ fato de ter ocorrido sinais evidentes de toxicidade materna e 
de toxicidade neonatal, comprovadas laboratorialmente, reforça esta possibilidade. A deficiência auditiva, neste caso, pode, não somente ser decorrente da ação do agrotóxico, mas também, das intercorrências neonatais e pós-natais, relacionadas aos fatores de risco: prematuridade, hipóxia, internação prolongada, uso de medicamentos ototóxicos, entre outros.

Anomalias craniofaciais, alterações atípicas de extremidades e deficiência auditiva foram manifestações clínicas observadas no Caso 87 (Tabela 14; Figura 130), da presente casuística. História gestacional de hipertensão arterial com uso de anti-hipertensivos e antecedente de prematuridade e baixo peso foram relevantes no caso em questão. Segundo informações, um dos medicamentos utilizados pela genitora, foi propanolol. Outros anti-hipertensivos foram utilizados, durante as várias internações ocorridas a partir do segundo mês de gestação, porém, não especificados. Consulta ao Sistema Nacional de Informações sobre Agentes Teratogênicos (SIAT) mostrou que o uso de propanolol não está associado a anomalias congênitas. Por outro lado, embora não haja informação suficiente sobre os diferentes anti-hipertensivos usados pela genitora do Caso 87, não se pode afirmar que estes não tiverem efeito teratogênico sobre o feto. Estudos têm mostrado que tratamento materno com anti-hipertensivos está associado, entre outras anomalias, com defeitos de redução de membros (Hurst et al 1995), achado este observado no Caso 87. Segundo esses mesmos autores, as anomalias são decorrentes de hipotensão materna, levando a uma redução do fluxo sangüíneo uteroplacentário e conseqüente hipotensão fetal e hipóxia (etiologia vascular). Outros antecedentes gestacionais relevantes, no presente caso, foram a prematuridade e o baixo peso. Esses podem justificar tanto a deficiência auditiva quanto o atraso no desenvolvimento neuromotor. Ao se considerar deficiência auditiva e defeitos de redução de membros, várias síndromes genéticas conhecidas cursam com essa associação. Dentre as principais, encontram-se: síndrome EEC (OMIM 129900), síndrome de Goltz-Gorlin (OMIM 305600), síndrome de Hanhart (OMIM 103300) e síndrome de Moebius (OMIM 157900). O padrão de anomalias de membros, nesses quadros, embora variável, difere do observado no Caso 87. Por outro lado, esse indivíduo apresenta perda auditiva sensorioneural e, com exceção da síndrome de GoltzGorlin, que pode apresentar componente sensorioneural, nas demais, a perda auditiva é condutiva. Considerando, ainda, a presença dos outros achados clínicos nesse indivíduo, 
tais como microcefalia, sobrancelhas anômalas, hipertelorismo mamário, mamilo extranumerário e, também, a inexistência de síndromes genéticas conhecidas que contemple esse conjunto de alterações, é possível que, o quadro como um todo, seja decorrente do efeito teratogênico de anti-hipertensivos. 


\subsection{Categoria III: síndromes de etiologia gênica e antecedente de fatores ambientais (Casos 88 a 93)}

Síndromes gênicas distintas foram observadas nos 6 indivíduos desse grupo. Os diagnósticos estabelecidos foram: síndrome Pitt-Rogers-Danks para o Caso 88; síndrome de Filippi para o Caso 89; síndrome Aarskog-Scott para o Caso 90; síndrome Silver-Russell para o Caso 91 e, síndrome Lujan-Fryns para o Caso 92. Para o Caso 93 duas possibilidades diagnósticas foram aventadas: síndrome de da-Silva e síndrome Chudley-McCullough. Antecedentes de fatores de risco para deficiência auditiva foram identificados em todos os indivíduos desse grupo. Deficiência auditiva do tipo sensorioneural foi observada em 4 indivíduos e do tipo mista, em 1. Para o Caso 88 , os resultados de exames audiológicos não permitiram conclusão sobre o tipo da deficiência auditiva. Os dados referentes a esse grupo foram apresentados na Tabela 15. 
TABELA 15: Dados dos indivíduos com síndrome de etiologia gênica e antecedente de fatores ambientais

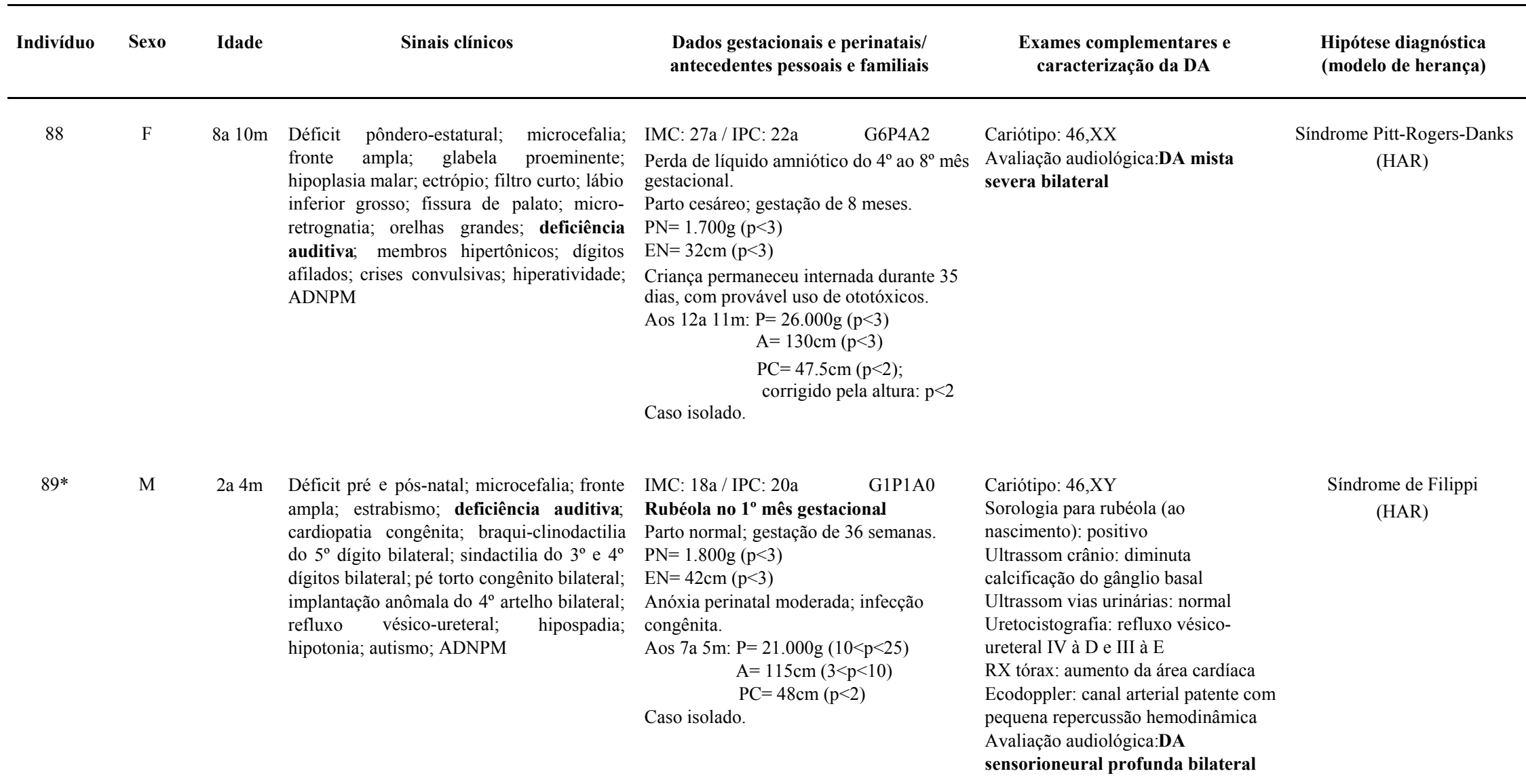


Continuação TABELA 15: Dados dos indivíduos com síndrome de etiologia gênica e antecedente de fatores ambientais

\begin{tabular}{|c|c|c|c|c|c|c|}
\hline Indivíduo & Sexo & Idade & Sinais clínicos & $\begin{array}{l}\text { Dados gestacionais e perinatais/ } \\
\text { antecedentes pessoais e familiais }\end{array}$ & $\begin{array}{l}\text { Exames complementares e } \\
\text { caracterização da DA }\end{array}$ & $\begin{array}{l}\text { Hipótese diagnóstica } \\
\text { (modelo de herança) }\end{array}$ \\
\hline 90 & M & $15 \mathrm{a}$ & $\begin{array}{l}\text { Braquicefalia;implantação em "V de cabelos } \\
\text { na região frontal; sobrancelhas grossas; } \\
\text { sinofre; ptose palpebral bilateral; } \\
\text { hipertelorismo ocular; narinas antevertidas; } \\
\text { orelhas posteriorizadas; deficiência } \\
\text { auditiva; pescoço largo; braquidactilia de } \\
\text { mãos; hiperextensibilidade de dígitos; pés } \\
\text { pequenos; pé torto congênito bilateral; } \\
\text { escroto em cachecol }\end{array}$ & $\begin{array}{l}\text { IMC: } 26 \mathrm{a} / \mathrm{IPC}: 25 \mathrm{a} \quad \mathrm{G} 5 \mathrm{P} 5 \mathrm{~A} 0 \\
\text { Exantema, no } 3^{\circ} \text { mês gestacional. } \\
\text { Sorologia positiva para rubéola } \\
\text { Parto normal; gestação a termo. } \\
\mathrm{PN}=2.600 \mathrm{~g}(\mathrm{p}=3) \\
\mathrm{EN}=\text { ? } \\
\text { Sem intercorrências perinatais. } \\
\text { Aos 16a idade: } \mathrm{A}=160 \mathrm{~cm}(3<\mathrm{p}<10) \\
\qquad \mathrm{DICI}=3.8 \mathrm{~cm}(\mathrm{p}>97) \\
\quad \text { DICE }=10.3 \mathrm{~cm}(\mathrm{p}>97) \\
\text { Avô materno com hiperextensibilidade de } \\
\text { dígitos e pé torto congênito bilateral; mãe } \\
\text { com braquidactilia de mãos e pé torto } \\
\text { congênito bilateral; } 1 \text { tia materna com } \\
\text { hiperextensibilidade de dígitos; pé torto } \\
\text { congênito bilateral. }\end{array}$ & $\begin{array}{l}\text { Cariótipo: } 46, X Y \\
\text { Avaliação radiológica: } \\
\text { braquimetacarpia } \\
\text { Avaliação urológica: escroto em } \\
\text { cachecol } \\
\text { Avaliaçcão audiológica:DA } \\
\text { sensorioneural profunda bilateral }\end{array}$ & $\begin{array}{l}\text { Síndrome Aarskog-Scott } \\
\text { (HL-X recessiva) }\end{array}$ \\
\hline 91 & M & $6 \mathrm{a} 9 \mathrm{~m}$ & $\begin{array}{l}\text { Baixa estatura; fronte larga e alta; fácies } \\
\text { triangular; discreta assimetria de face; } \\
\text { sinofre; miopia bilateral; dentição tardia; } \\
\text { deficiência auditiva; manchas café-com- } \\
\text { leite na região do tórax; nevus na face, no } 2^{\circ} \\
\text { dígito D e dorso; ADNM leve }\end{array}$ & $\begin{array}{l}\text { IMC: } 24 \mathrm{a} \text { / IPC: } 30 \mathrm{a} \quad \text { G4P4A0 } \\
\text { Engravidou na vigência de uso de DIU. } \\
\text { Rompimento da bolsa no } 4^{\circ} \text { mês } \\
\text { gestacional; descolamento de placenta. } \\
\text { Parto cesáreo; } \text { gestação de } 5 \text { meses e } 1 \\
\text { semana. } \\
\text { PN= 800g } \\
\text { EN=30cm } \\
\text { Internado durante } 4 \text { meses e } 1 \text { semana. } \\
\text { Nasceu com displasia pulmonar. Até os } 2 \\
\text { anos de idade, apresentou } \\
\text { broncopneumonias de repetição. } \\
\text { Aos } 8 \mathrm{a} 8 \mathrm{~m}: \mathrm{P}=19.100 \mathrm{~g}(\mathrm{p}<3) \\
\qquad \mathrm{A}=110 \mathrm{~cm}(\mathrm{p}<3) \\
\qquad \mathrm{CC}=48.5 \mathrm{~cm}(\mathrm{p}<2) ; \text { corrigido } \\
\text { pela altura: } 2<\mathrm{p}<50\end{array}$ & $\begin{array}{l}\text { Cariótipo: } 46, \mathrm{XY} \\
\text { HGH, T4 livre, T4 total, TSH, } \\
\text { cratinina, fosf. Alcalino, cálcio, } \\
\text { fósforo, ferro: normais } \\
\text { Aos } 7 \mathrm{a} 7 \mathrm{~m} \text { : idade óssea compatível } \\
\text { com } 4 \mathrm{a} \\
\text { Avaliação audiológica:DA mista } \\
\text { moderada bilateral }\end{array}$ & $\begin{array}{l}\text { Síndrome Silver-Russel } \\
\text { (HAD) }\end{array}$ \\
\hline
\end{tabular}


Continuação TABELA 15: Dados dos indivíduos com síndrome de etiologia gênica e antecedente de fatores ambientais

\begin{tabular}{|c|c|c|c|c|c|c|}
\hline Indivíduo & Sexo & Idade & Sinais clínicos & $\begin{array}{l}\text { Dados gestacionais e perinatais/ } \\
\text { antecedentes pessoais e familiais }\end{array}$ & $\begin{array}{l}\text { Exames complementares e } \\
\text { caracterização da DA }\end{array}$ & $\begin{array}{l}\text { Hipótese diagnóstica } \\
\text { (modelo de herança) }\end{array}$ \\
\hline 92 & $\mathrm{~F}$ & $14 \mathrm{a} 4 \mathrm{~m}$ & $\begin{array}{l}\text { Alta estatura; fácies longo; fronte ampla e } \\
\text { alta; hipoplasia malar; micrognatia; } \\
\text { hipotonia labial; deficiência auditiva; } \\
\text { pescoço longo; mãos e dedos longos; habitus } \\
\text { marfanóide; hiperextensibilidade articular; } \\
\text { distúrbio de comportamento (apatia, } \\
\text { timidez); distúrbio de aprendizagem; } \\
\text { ADNPM. }\end{array}$ & $\begin{array}{l}\text { IMC: } 25 \mathrm{a} \text { / IPC: } 27 \mathrm{a} \quad \text { G1P1A0 } \\
\text { Perda de líquido amniótico no } 6^{\circ} \text { mês } \\
\text { gestacional. } \\
\text { Parto fórceps; gestação de } 31 \text { semanas. } \\
\text { PN= 900g (p<3) } \\
\text { EN=? } \\
\text { Apresentação pélvica.Anóxia neonatal } \\
\text { Recebeu hemotransfusão.Internada } 45 \\
\text { dias. } \\
\text { Aos } 17 \text { a 9m idade: } \mathrm{A}=178 \mathrm{~cm}(\mathrm{p}>97) \\
\text { Mãe com mecha branca de cabelos na } \\
\text { região parietal E, hipoplasia malar e } \\
\text { micrognatia e apatia; } 2 \text { primos maternos } \\
\text { com fácies longo, distúrbio de } \\
\text { aprendizagem e de linguagem. }\end{array}$ & $\begin{array}{l}\text { Cariótipo: } 46, \mathrm{XX} \\
\text { Avaliação audiológica:DA } \\
\text { sensorioneural moderada bilateral }\end{array}$ & $\begin{array}{l}\text { Síndrome Lujan-Fryns } \\
\text { (HL-X dominante) }\end{array}$ \\
\hline 93 & M & $4 \mathrm{a} 7 \mathrm{~m}$ & $\begin{array}{l}\text { Déficit pôndero-estatural; microcefalia; } \\
\text { fácies longo; deficiência auditiva; pé torto } \\
\text { congênito bilateral; hipotonia generalizada; } \\
\text { ADNPM }\end{array}$ & $\begin{array}{l}\text { IMC: } 20 \mathrm{a} \text { / IPC: } 22 \mathrm{a} \quad \text { G4P3A1 } \\
\text { Sem intercorrências gestacionais. } \\
\text { Parto normal; gestação a termo. } \\
\mathrm{PN}=2.410 \mathrm{~g}(\mathrm{p}<3) \\
\mathrm{EN}=\text { ? } \\
\text { Circular de cordão; traumatismo de } \\
\text { parto; crise convulsiva com suspeita de } \\
\text { hemorragia intra-craniana; quadro } \\
\text { infeccioso com uso de aminoglicosídeos } \\
\text { por } 10 \text { dias. } \\
\text { Aos } 10 \mathrm{a} 2 \mathrm{~m} \text { idade: } \mathrm{P}=24.900 \mathrm{~g}(3<\mathrm{p}<10) \\
\qquad \mathrm{A}=128 \mathrm{~cm}(3<\mathrm{p}<10) \\
\qquad \mathrm{PC}=48.5 \mathrm{~cm}(\mathrm{p}<2)\end{array}$ & $\begin{array}{l}\text { Cariótipo: } 46, \mathrm{XY} \\
\text { Tomografia computadorizada crânio- } \\
\text { encefálica: disgenesia de corpo caloso } \\
\text { Avaliação audiológica:DA } \\
\text { sensorioneural profunda bilateral }\end{array}$ & $\begin{array}{c}\text { Síndrome da-Silva ? } \\
\text { (HAR) } \\
\text { Síndrome } \\
\text { Chudley-McCullough? } \\
\text { (HAR) }\end{array}$ \\
\hline
\end{tabular}



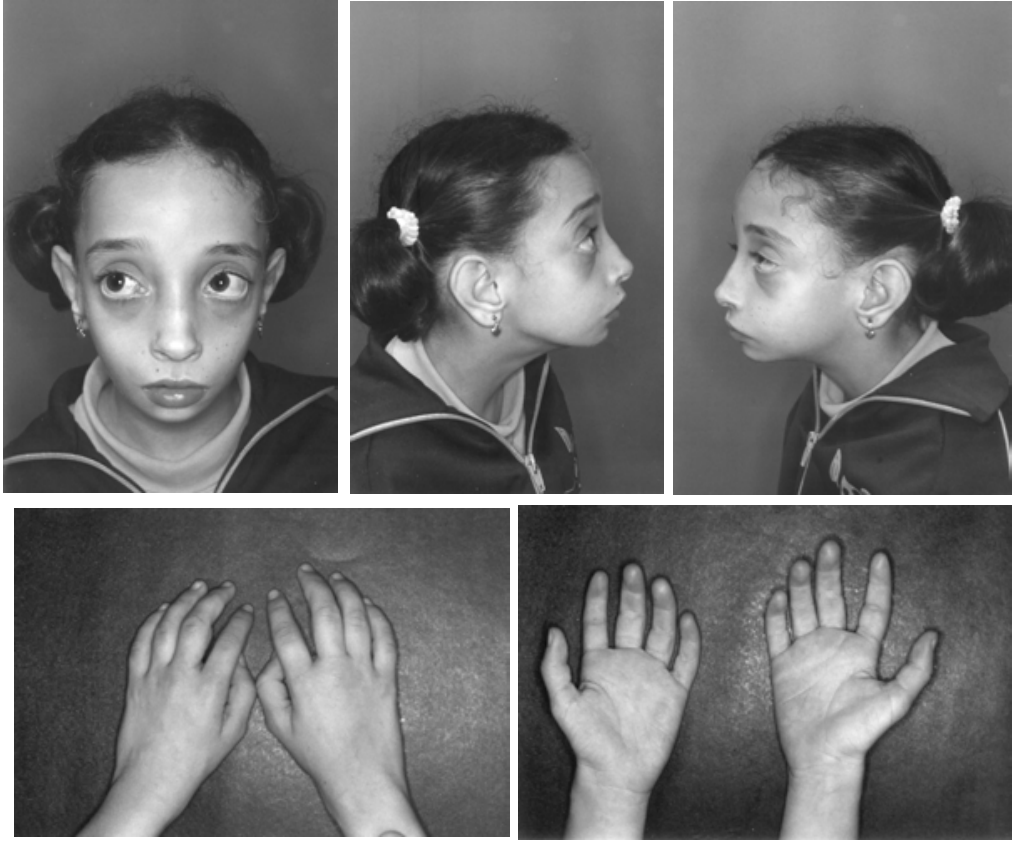

FIGURA 131: Aspectos clínicos e radiológicos do Caso 88

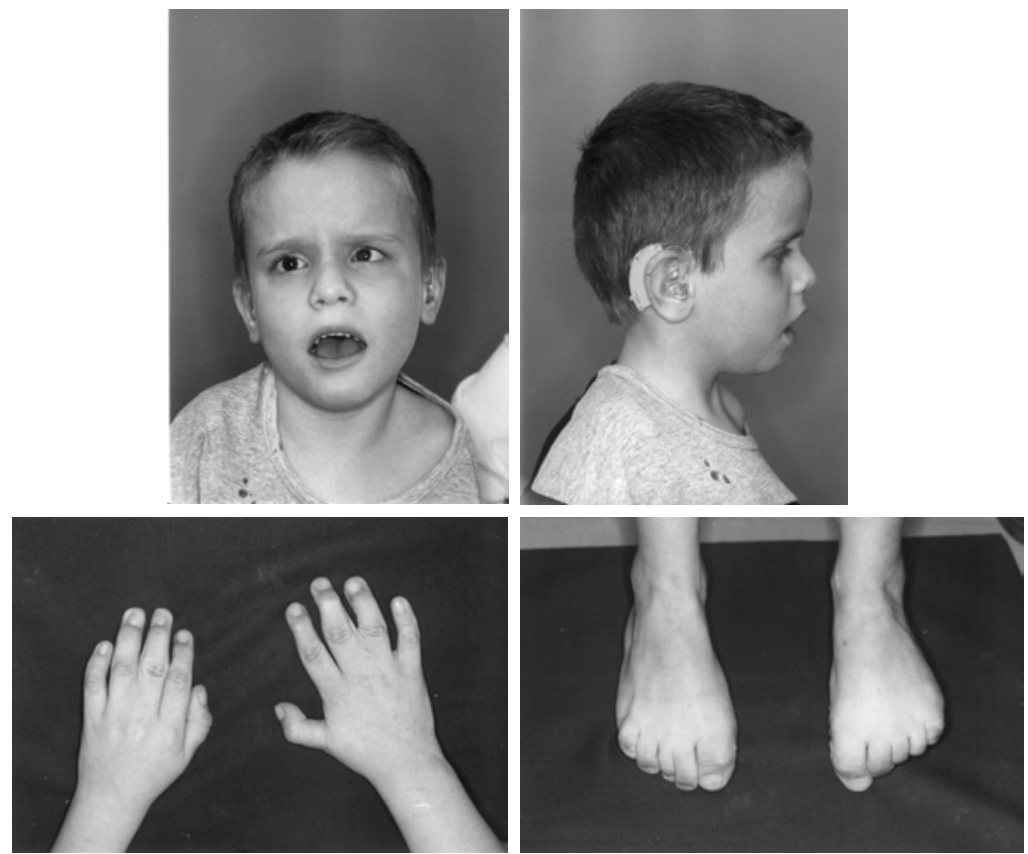

FIGURA 132: Aspectos clínicos do Caso 89 

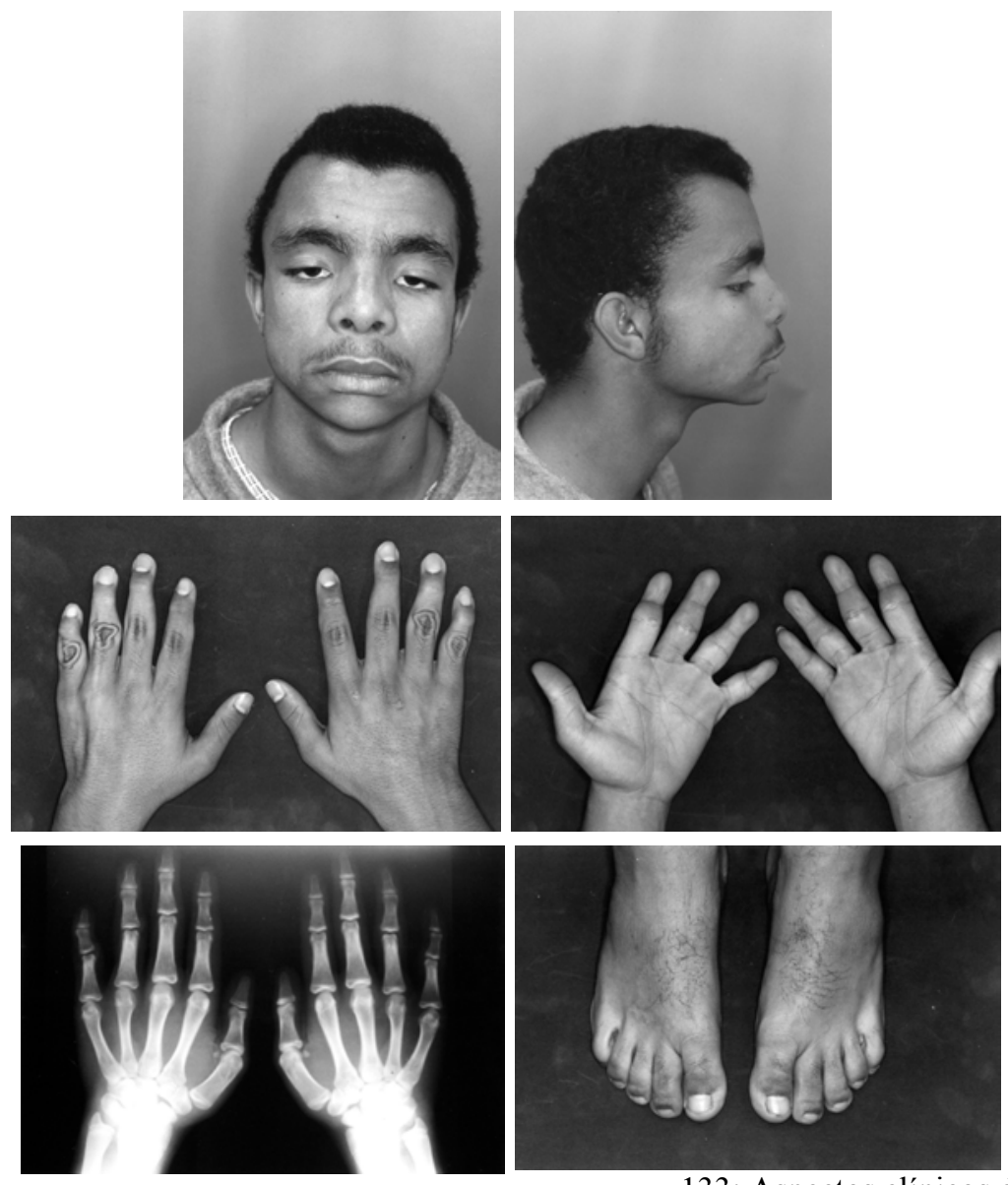

FIGURA

133: Aspectos clínicos do Caso 90

I

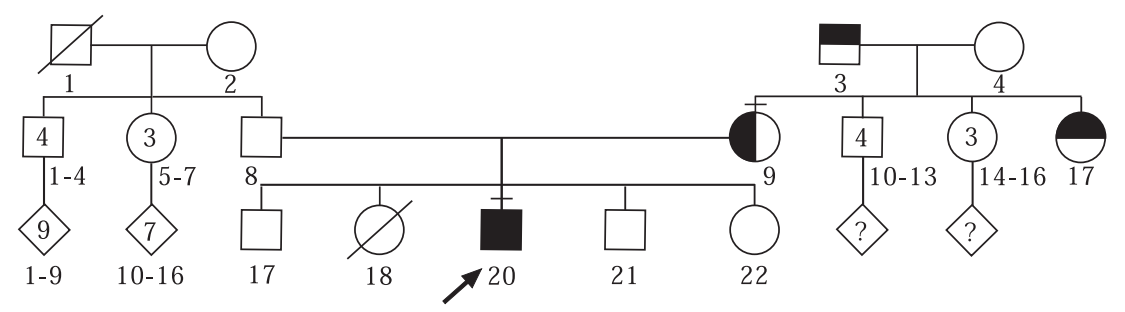

- Propósito

Braquidactilia mãos; pé torto congênito bilateral

๑ Camptodactilia mãos; pé torto congênito bilateral

FIGURA 134: Heredograma da família do Caso 90 

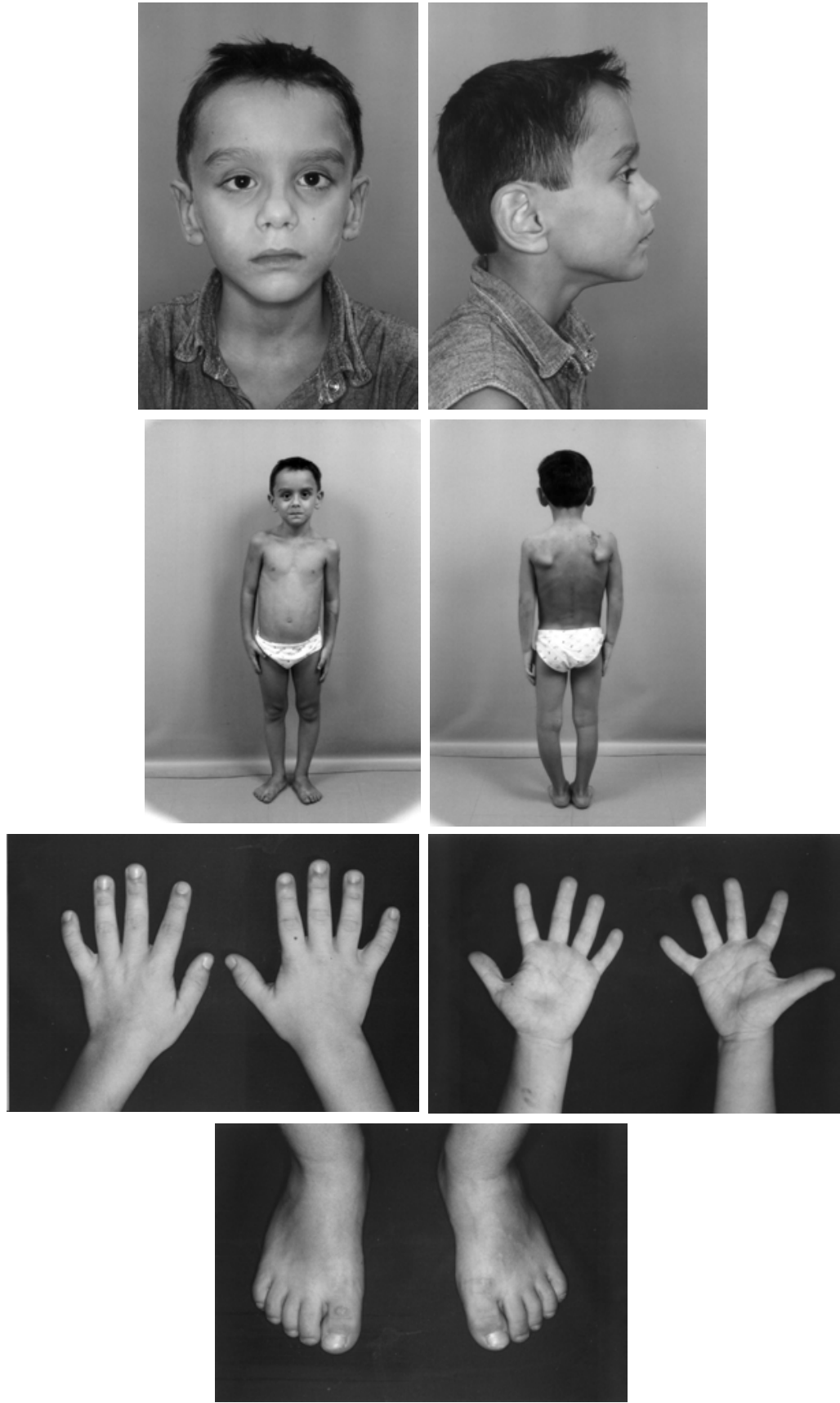

FIGURA 135: Aspectos clínicos do Caso 91 

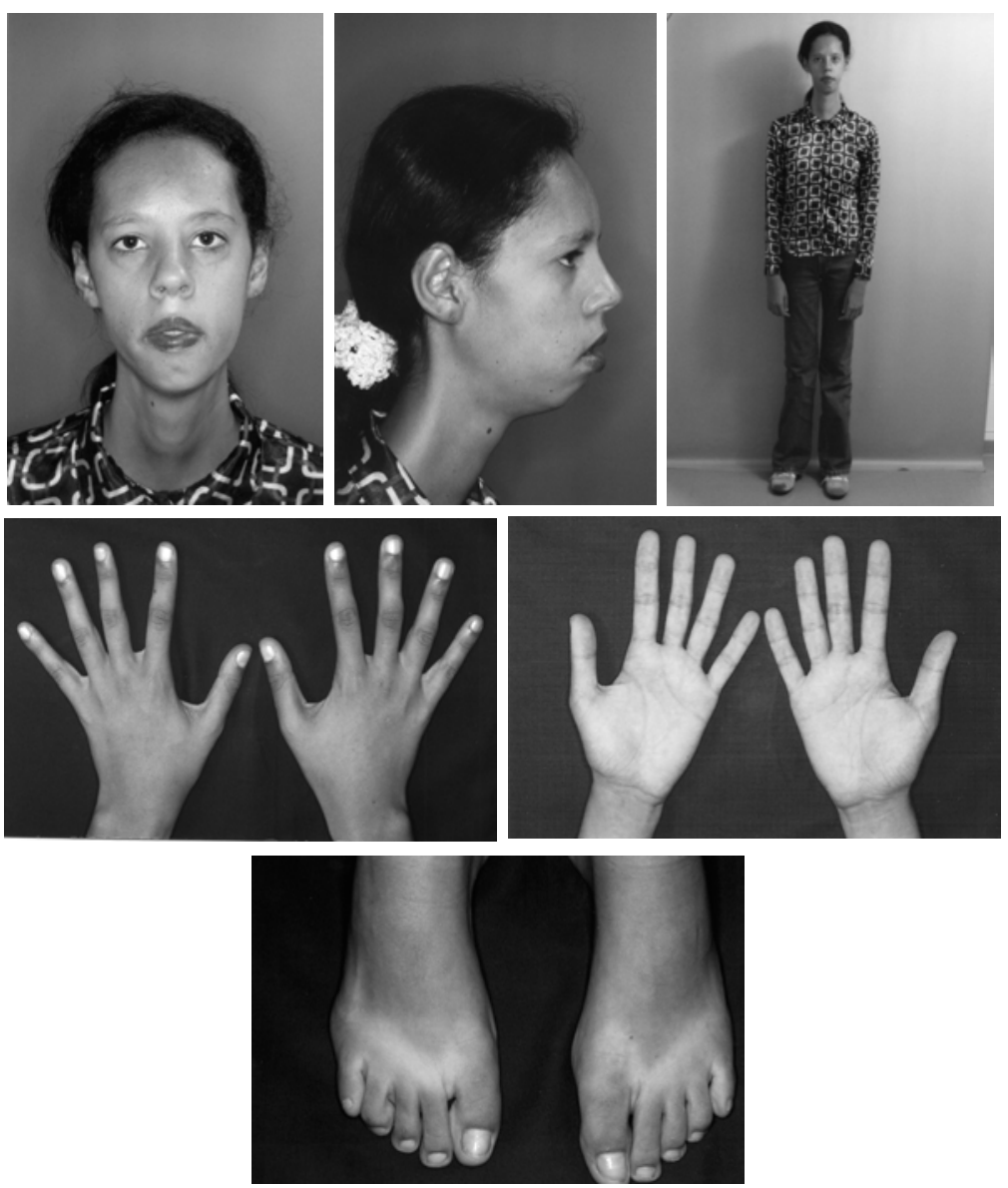

FIGURA 136: Aspectos clínicos do Caso 92
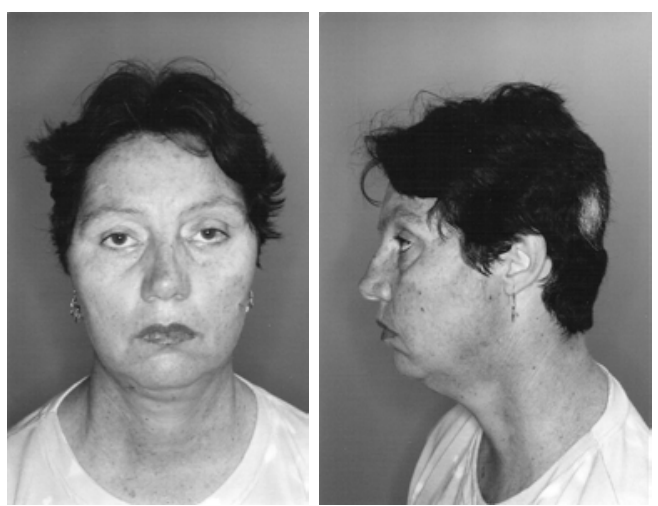

FIGURA 137: Aspectos clínicos da genitora do Caso 92 


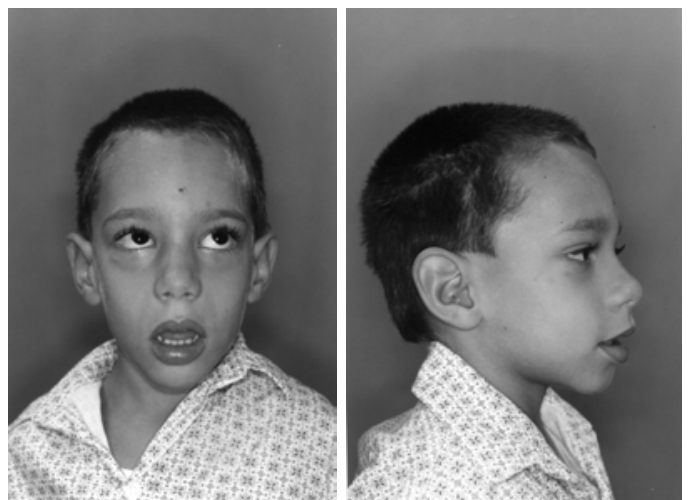

FIGURA 138: Aspectos clínicos do Caso 93 
Embora diversos fatores ambientais possam estar associados às anomalias congênitas, por manifestarem efeitos deletérios, especialmente no período peri e pós-natal, nem sempre são os responsáveis pelo quadro, como um todo, presente no indivíduo. Os fatores de risco para perda auditiva, como estabelecido pelo "Joint Committee on Infant Hearing" (1994, 2000), tais como infecções congênitas, prematuridade, baixo peso, anóxia neonatal, hiperbilirrubinemia, uso de ototóxicos e presença de malformações de cabeça e pescoço têm sido intensamente estudados, produzindo dados conflitantes em relação às condições clínicas e aos tratamentos utilizados nas unidades de terapia intensivas (Eavey et al 1996, Kountakis et al 2002, de Hoog et al 2003). Entretanto, até o momento, não está bem esclarecida a etiopatogenia da deficiência auditiva nesses indivíduos, pois são poucos os estudos histológicos na literatura, no sentido de esclarecê-la (Sassada et al 2005). Estudo realizado por Amatuzzi et al (2005), mostrou que a heterogeneidade das lesões histopatológicas observadas, sugerem a participação de mais de um fator etiológico para a perda auditiva, em recém-nascidos de alto risco. Na presente casuística, os Casos 88 a 93 (Tabela 15) apresentaram síndromes de etiologia genética, conhecida ou não, associada à deficiência auditiva. Os diagnósticos estabelecidos nesse grupo, tais como: síndrome Pitt-Rogers-Danks, síndrome de Aarskog-Scott, síndrome de Filippi, síndrome SilverRussell e síndrome Lujan-Fryns, não cursam com perda auditiva. Por outro lado, todos os indivíduos desse grupo apresentaram fatores de risco para perda auditiva (infecção materna exantemática não especificada, rubéola gestacional, prematuridade, baixo peso, medicamentos ototóxicos).

O Caso 88 (Tabela 15; Figura 131) apresentou fácies típico, perda auditiva mista e atraso neuropsicomotor importante. O estudo citogenético, através de bandamento $\mathrm{G}$, foi normal. Considerando a aparência facial desse indivíduo, duas possibilidades diagnósticas foram consideradas: síndrome Wolf-Hirschhorn (OMIM 194190) e síndrome Pitt-Rogers-Danks (OMIM 262350). Há evidências de que esses quadros são estreitamente relacionados e decorrentes de deleções envolvendo a região do 4 p16.3, nem sempre detectada citogeneticamente. A similaridade no tamanho das regiões críticas, entre as síndromes Pitt-Rogers-Danks e Wolf-Hirschhorn, em combinação com a similaridade fenotípica, sugere que representem o espectro clínico da mesma condição (Wright et al 1998). A tríade atraso de crescimento pré e pós-natal, microcefalia e atraso mental (mais grave na síndrome Wolf-Hirschhorn) são achados clínicos comuns nas 
duas condições. Por outro lado, anomalias oculares; fissura labiopalatina; defeito cardíaco; anomalias esqueléticas, geniturinárias e de sistema nervoso central, são manifestações clínicas observadas nos indivíduos com síndrome Wolf-Hirschhorn. De forma geral, o fenótipo mais acentuado tem sido relacionado à síndrome WolfHirschhorn e, expressões mais leves, à síndrome Pitt-Rogers-Danks. Para explicar a grande variabilidade fenotípica nesse quadro, pesquisadores têm estudado a correlação entre o tamanho da deleção $4 p$ e a gravidade das manifestações clínicas. Pequenas deleções tendem a estarem associadas com fenótipo mais leve no que se refere à gravidade do atraso mental e à presença de malformações maiores (Zollino et al 2003, Titomanlio et al 2004). Em relação ao Caso 88, o fenótipo, de forma geral é leve e, portanto, mais compatível com a síndrome Pitt-Rogers-Danks. Das malformações maiores relacionadas a deleções maiores do $4 p$ (Wieczorek et al 2000), somente fissura de palato foi observada nesse indivíduo. Atraso mental no Caso 88, embora acentuado, pode ter sido agravado pela presença da deficiência auditiva. Perda auditiva não é parte do espectro fenotípico da síndrome de Pitt-Rogers-Danks. É possível que, para o caso em questão, antecedentes de prematuridade, baixo peso, período prolongado de internação, fatores esses considerados de risco para perda auditiva, tenha exercido influência na etiologia da deficiência auditiva.

Os Casos 89 e 90 (Tabela 15), da presente casuística, apresentaram antecedente gestacional de infecção materna exantemática no primeiro trimestre gestacional. O Caso 89 (Figura 132) apresentou fenótipo compatível com a síndrome de Filippi (OMIM 272440), condição clinicamente variável e caracterizada por alterações craniodigitais. Recorrência na irmandade e consangüinidade parental, observados em indivíduos com essa condição, têm sugerido modelo de herança autossômica recessiva (Filippi 1985, Meinecke 1993, Heron et al 1995). Sinais clínicos importantes nesse quadro são: atraso de crescimento pré e pós-natal, microcefalia, sindactilia cutânea de dígitos e artelhos e atraso mental. Outros sinais menos comuns, como alteração ocular, cardiopatia, fissura de palato, anomalias esqueléticas, polidactilia e alteração dentária têm sido observados em indivíduos com síndrome de Filippi (Woods et al 1992, Toriello e Higgins 1995, Heron et al 1995, Williams et al 1999, Franceschini et al 2002, Sharif e Donnai 2004). Manifestações clínicas como refluxo vésico-ureteral, hipospadia e autismo, observadas no Caso 89, não foram, previamente, descritas em indivíduos com essa condição, podendo representar achados adicionais. Embora clinicamente compatível com o 
diagnóstico de síndrome de Filippi, o caso em questão foi diferenciado, principalmente, da síndrome craniodigital de Scott com atraso mental (OMIM 312860), descartada pela ausência de microcefalia e pelo padrão facial. Já, o Caso 90 (Figuras 133 e 134; III-20) apresentou, dentre as principais manifestações clínicas, implantação em "V" de cabelos na região frontal, ptose palpebral bilateral, hipertelorismo ocular, narinas antevertidas, orelhas posteriorizadas, braquidactilia de mãos, hiperextensibilidade articular de dígitos e escroto em cachecol. Esses achados clínicos são compatíveis com a síndrome Aarskog-Scott (OMIM 305400), condição de herança ligada ao X recessiva e causada por mutações no gene FGD1. Manifestações clínicas mais leves (braquidactilia de mãos, hiperextensibilidade articular de dígitos e pé torto congênito) foram observadas em sua genitora (Figura 134; II-9), tia materna (Figura 134; II-17) e avô materno (Figura 134; I-9) (não avaliado urologicamente). A sobreposição clínica entre a síndrome Aarskog-Scott e a síndrome Aarskog-like (OMIM 227330) é acentuada e de difícil diferenciação. Considerando a literatura pertinente, até o momento, deficiência auditiva não foi referida como parte integrante do quadro clínico da síndrome de Filippi e da síndrome Aarskog-Scott. Diante do exposto, é plausível que a deficiência auditiva sensorioneural, presente nos Casos 89 e 90, tenha sido de fato, decorrente da infecção materna. O quadro infeccioso materno, no Caso 89, foi sorologicamente diagnosticado como rubéola e, no Caso 90, embora não especificado, o quadro foi sugestivo de rubéola. Perda auditiva pode ser manifestação única em indivíduos com história positiva para rubéola gestacional (Chakravarti e Jain 2006). Cabe, ainda, comentar que, tanto a hipospadia quanto o autismo, presentes no Caso 89, foram relacionados à rubéola congênita (Chess 1977, Avellan 1977, Libbey et al 2005).

Outros fatores de risco, para deficiência auditiva, tais como, prematuridade, baixo peso, anóxia neonatal e uso de medicamentos ototóxicos têm sido alvo de vários trabalhos importantes, no sentido de comprovar a alteração da função auditiva em decorrência da exposição a esses fatores. Os Casos 91, 92 e 93 (Tabela 15), da presente casuística, apresentaram, além de múltiplas anomalias congênitas, antecedentes de prematuridade e baixo peso ao nascimento, com complicações neonatais e longo período de internação. Os achados clínicos do Caso 91 (Figura 135) foram compatíveis com o diagnóstico de síndrome Silver-Russell (OMIM 180860), condição caracterizada, principalmente, por déficit de crescimento intrauterino; fácies triangular, pequeno e com bossa frontal e, assimetria de membros. A causa da síndrome Silver-Russel é, ainda, desconhecida e a 
maioria dos casos é esporádica. Nenhuma base mendeliana ou cromossômica, para essa condição, tem sido claramente estabelecida e o diagnóstico é, ainda, baseado em características dismórficas típicas e crescimento assimétrico (Price et al 1999). Heterogeneidade genética, com formas autossômica dominante e recessiva e alterações cromossômicas (deleção, translocação ou mosaicismo) têm sido relatadas em indivíduos com síndrome Silver-Russell (Duncan et al 1990, Midro et al 1993, Eggerding et al 1994, Wollmann et al 1995, Al-Fifi et al 1996, Dupont et al 2002, Monk et al 2002, Ounap et al 2004). É muito provável que um ou mais genes sejam responsáveis pelo fenótipo dessa síndrome (Falkert et al 2005). Todos os sinais clínicos presentes no Caso 91, exceto a deficiência auditiva, foram previamente relatados em indivíduos com a síndrome Silver-Russell. O fato de a perda auditiva não pertencer ao quadro clínico dessa síndrome, leva a considerar que, muito provavelmente, os antecedentes perinatais e neonatais estejam diretamente relacionados com a etiologia da perda auditiva. Baixo peso ao nascer, sinal cardinal da síndrome, possivelmente, não influenciou na perda auditiva do indivíduo em questão.

Já, o Caso 92 (Figura 136), da presente casuística, apresentou, com exceção da deficiência auditiva, fenótipo consistente com o diagnóstico da síndrome Lujan-Fryns (OMIM 309520). Essa é uma condição rara, ligada ao X dominante, com alta penetrância e maior expressividade no sexo masculino. É clinicamente caracterizada por aparência craniofacial típica (fácies longo e estreito, hipoplasia malar, micrognatia), habitus marfanóide, hipotonia, hiperextensibilidade articular, voz hipernasal e leve a moderado atraso mental. Outras manifestações clínicas, tais como, fissura de palato submucosa, incompetência velofaringeana, cardiopatia e distúrbios comportamentais são observados em indivíduos com essa síndrome (Wittine et al 1999, Stathopulu et al 2003, Alonso et al 2006). Problemas de comportamento representam um bom critério clínico para o diagnóstico da síndrome, uma vez que, estão presentes em cerca de $80 \%$ dos casos (Purandare e Markar 2005). O Caso 92, indivíduo do sexo feminino, apresentou fácies e habitus marfanóide típicos da síndrome Lujan-Fryns. Atraso mental e distúrbio de comportamento, esse último, relevante nesse quadro, estavam presentes no Caso 92. Já, deficiência auditiva, outro achado clínico nesse caso, não foi previamente relatado em indivíduos com a síndrome Lujan-Fryns. Considerando que essa condição encontra-se em fase inicial de delineamento e, ainda, a escassez de relatos, não se pode afirmar se este sinal pertence, ou não, ao espectro fenotípico da 
condição. Importante salientar que, para o caso em questão, a presença de antecedentes neonatais e perinatais relevantes (prematuridade, baixo peso, anóxia neonatal) possam estar relacionados com a etiologia da perda auditiva. Hipoplasia malar, micrognatia e, ainda, apatia observadas na genitora do Caso 92, pode representar forma leve do quadro. A síndrome Lujan-Fryns apresenta acentuada sobreposição clínica com a síndrome velocardiofacial (OMIM 192430), porém, presença de habitus marfanóide descarta essa possibilidade.

Medidas terapêuticas, potencialmente ototóxicas, podem promover deficiência auditiva irreversível em recém-nascidos com intercorrências graves, internados nas unidades de tratamento intensivo. Pequenas dosagens de aminoglicosídeos podem determinar ação tóxica, havendo variação individual quanto à susceptibilidade. Posteriormente à penetração de um metabólito do aminoglicosídeo na célula ciliada auditiva, as lesões podem evoluir até a destruição celular e conseqüente perda auditiva (Yoon et al 2003). O Caso 93 (Figura 138), da presente casuística, apresentou antecedente de traumatismo de parto e quadro infeccioso, no período perinatal, com uso de medicamentos ototóxicos (garamicina e amicacina), até o décimo quarto dia de vida. Quadro clínico com microcefalia, agenesia de corpo caloso, pé torto congênito, hipotonia, convulsões, atraso no desenvolvimento neuropsicomotor e deficiência auditiva sensorioneural, foi observado nesse indivíduo, quando de sua avaliação aos 4 anos e 7 meses de idade. Para esse caso, duas hipóteses diagnósticas foram consideradas. A primeira, síndrome da-Silva tem, como sinais cardinais, agenesia de corpo caloso, microcefalia e atraso mental (da Silva 1988, Naritomi et al 1994). Trata-se de quadro grave e determinado por gene autossômico recessivo. Perda auditiva não foi relatada em indivíduos com essa condição e, por outro lado, em todos os casos previamente descritos, o atraso mental era acentuado e o prognóstico, ruim. O Caso 93, da presente casuística, embora apresente atraso mental, este é leve. Considerando que o delineamento da síndrome da-Silva encontra-se em fase inicial e que, o seu espectro fenotípico possa ser mais amplo do que se conhece, esta possibilidade diagnóstica não pôde ser excluída para o Caso 93. Cabe salientar que antecedente de aminoglicosídeo, para o caso em questão, pode justificar a perda auditiva sensorioneural. Outra possibilidade diagnóstica considerada para o Caso 93 foi a síndrome ChudleyMcCullough (OMIM 604213), condição rara, determinada por gene autossômico recessivo e, clinicamente, caracterizada por agenesia de corpo caloso, hidrocefalia (pela 
obstrução do forâmen de Monro) e deficiência auditiva sensorioneural profunda (Ostergaard et al 2004, Matteucci et al 2006). Embora hidrocefalia tenha sido observada nos 11 casos descritos até então, o fato de a agenesia de corpo caloso, e não a obstrução do forâmen de Monro, representar o defeito básico de desenvolvimento, leva a considerar a síndrome Chudley-McCullough como diagnóstico provável para o Caso 93. Em se tratando desse quadro, o uso de aminoglicosídeo no período neonatal poderia, ou não, ter influenciado na etiologia da perda auditiva. Finalmente, é possível, ainda, que o Caso 93 apresente um quadro genético não definido e que a deficiência auditiva tenha sido decorrente de fator ambiental. 


\section{CONSIDERAÇÕES}

FINAIS 


\section{CONSIDERAÇÕES FINAIS}

A arte da dismorfologia é, simplesmente, a mais detalhada avaliação da história e da clínica de um indivíduo potencialmente dismórfico (Hall, 1993). Isso, além de requerer precisa observação e coleta de todas as características físicas, seguidas pela interpretação, categorização e diagnóstico, requer um entendimento da morfogênese combinada com uma apreciação da forma. A dismorfologia, palavra criada para descrever o estudo de malformações humanas significa, literalmente, o estudo da forma anormal, enfatizando anormalidades estruturais do desenvolvimento. É, principalmente, uma especialidade visual, considerada como base do conhecimento que, por meio de dois processos, a interpretação e a categorização do observado, pode se chegar ao diagnóstico final. Por outro lado, há situações em que a identificação precisa de cada síndrome malformativa requer um conhecimento especializado que, em geral, depende de um conjunto de profissionais de uma equipe multidisciplinar.

As dismorfias apresentam incidência relativamente alta e, por nem sempre acarretar a morte dos afetados, torna-se grave problema pessoal, familiar e social (Freire-Maia, 1976). Cerca de $30 \%$ a $50 \%$ dos pacientes avaliados por um dismorfologista podem não ter diagnóstico de uma síndrome específica (Hall, 1993). O acompanhamento regular desses indivíduos, com síndromes desconhecidas ou com múltiplas anomalias congênitas, é importante, pois tempo e novos dados fornecem, no mínimo, $10 \%$ de chance de se fazer um diagnóstico específico. Por outro lado, o acompanhamento regular de indivíduos com diagnóstico estabelecido, mostra, por vezes, a necessidade de revisão desse. A importância do seguimento ficou evidente na presente casuística, onde vários indivíduos, por diferentes motivos, continuam sem diagnóstico estabelecido. Considerando o universo das deficiências auditivas sindrômicas, várias são as razões, não somente para um diagnóstico incompleto, mas, também, para uma revisão diagnóstica. A perda auditiva, em muitas síndromes, se apresenta como achado leve ou inconstante e, em outras, como achado constante e cardinal (Nance 2003). As alterações de outros sistemas, que acompanham a deficiência auditiva, podem ser sutis ou óbvias e podem, ainda, ser congênitas ou de início tardio. Um exemplo que ilustra esse ponto é a síndrome de Usher. A perda auditiva, nesse quadro, pode ser congênita, enquanto que a retinose pigmentar pode não ser notada 
precocemente. Assim, crianças com esse quadro são, freqüentemente, diagnosticadas como tendo deficiência auditiva não sindrômica. Outro exemplo é a síndrome de Perrault, condição que cursa com deficiência auditiva e disgenesia gonadal em meninas. Meninos afetados podem ter como único achado, a perda auditiva e, nesse caso, erroneamente considerados como tendo deficiência auditiva não sindrômica. Esses exemplos mostram a importância do seguimento e da investigação criteriosa. Sendo, ainda, a deficiência auditiva uma alteração fisiológica e não dismorfológica, cabe ressaltar a relevância de se investigar, criteriosamente, possível acometimento de outros sistemas que, no conjunto, poderá estar sinalizando a presença de quadro sindrômico.

Considerando a presente casuística, a heterogeneidade da deficiência auditiva, associada a outras anomalias, dá uma idéia geral da complexidade do estudo sindromológico das diversas condições envolvidas. Nesse contexto, destacou-se o grupo de indivíduos com síndrome da atresia aural, microtia e deficiência auditiva condutiva ou com espectro oculoauriculovertebral, onde nem sempre foi possível, pela acentuada sobreposição clínica, uma definição entre os dois quadros. Em outras situações, não foi possível se estabelecer um diagnóstico e, nesses casos, o seguimento da evolução fenotípica, a realização de novos exames complementares e as avaliações audiológicas periódicas podem auxiliar no processo de delineamento sindrômico. Por outro lado, o papel da genética molecular tem sido importante para o esclarecimento de condições fenotipicamente distintas, decorrentes de mutações alélicas, como as síndromes de Marshall e de Stickler tipo 2, a SW tipo I e tipo III; ou para o esclarecimento de fenótipos idênticos, causados por mutações em genes diferentes.

A revolução causada pela biologia molecular tem originado enorme impacto no estudo da audição e das suas doenças, contribuindo cada vez mais com a identificação de novos genes responsáveis pela deficiência auditiva não sindrômica. Por outro lado, alguns genes identificados, que causam a forma isolada de perda auditiva, são também responsáveis por formas sindrômicas de deficiência auditiva (Cryns e van Camp 2004). Assim, a ampliação do conhecimento dos fundamentos genéticos e moleculares do sistema auditivo normal pode, não somente, se estender ao conhecimento das formas não sindrômicas de deficiência auditiva como, também, das formas sindrômicas. Esses avanços proporcionarão, sem dúvida, um diagnóstico mais acurado, intervenção precoce, melhores resultados e adequado aconselhamento genético. 


\section{CONCLUSÕES}




\section{CONCLUSÕES}

Do presente estudo de 93 indivíduos com deficiência auditiva e comprometimento de outras estruturas anatômicas/sistemas fisiológicos, pôde-se concluir que:

- a casuística se compôs de síndromes etiologicamente heterogêneas, com maior freqüência de etiologia genética;

- para os Casos 1, 2 e 3, da Categoria I, que cursam com alterações cromossômicas, é possível que o quadro clínico não tenha relação com o achado citogenético e, que a presença de fatores de risco tenha implicação na etiologia da deficiência auditiva;

- o tipo de deficiência auditiva, em todos os indivíduos da Categoria I, que apresentaram síndromes gênicas, foi condizente com o quadro diagnosticado. Fator de risco para deficiência auditiva, no Caso 61, pode ter exercido influência na etiologia dessa;

- na Categoria II, os Casos 83, 84 e 85 apresentaram síndromes clássicas de etiologia ambiental e que cursam com diferentes tipos de deficiência auditiva. Os Casos 86 e 87 apresentaram quadro clínico, possivelmente decorrente do efeito do teratógeno envolvido, sem representar síndrome conhecida;

- fatores de risco para deficiência auditiva, muito provavelmente, tiveram implicação direta na etiologia da perda auditiva dos indivíduos da Categoria III, com diagnóstico de síndromes gênicas conhecidas que não cursam com deficiência auditiva;

- exceção feita ao diabetes, rubéola, álcool, anti-hipertensivos e agrotóxicos, os demais antecedentes gestacionais não foram relevantes como fatores causais;

- o Caso 55, possivelmente, representa uma síndrome nova de padrão único, de etiologia desconhecida e que cursa com anomalias de primeiro e segundo arcos branquiais associada a hipopigmentação de pele;

- o aconselhamento genético estará na dependência da fase em que se encontra o processo de delineamento das diferentes condições estabelecidas. Assim: 
- para os indivíduos com síndromes de etiologia conhecida o aconselhamento deve ser realizado de acordo com o risco de recorrência existente para cada modelo de herança;

- para o Caso 5, com monossomia do X, o risco de recorrência pode ser considerado desprezível;

- para os indivíduos com síndromes gênicas raras (Casos 27 e 28) o aconselhamento genético deve ser cauteloso até que o modelo de herança esteja bem estabelecido;

- para os indivíduos com síndromes de genealogia, cuja herança pode ser dominante ou recessiva: o aconselhamento genético deve ser cauteloso em relação aos casos isolados. É o caso dos indivíduos 30, 31, 32 e 34 com síndrome da atresia aural, microtia e deficiência auditiva condutiva; do Caso 50 com síndrome de Treacher-Collins e, dos Casos 51 e 52 com síndrome de Nager.

- para os indivíduos com síndromes de etiologia heterogênea: risco de recorrência é baixo, da ordem de 3\%. É o caso do indivíduo 29 com síndrome de CHARGE e, dos indivíduos 44 a 47 com espectro oculoauriculovertebral;

- para os casos isolados, com sobreposição clínica de quadros etiologicamente diferentes (síndrome de atresia aural, microtia e deficiência auditiva condutiva e espectro oculoauriculovertebral) o risco de recorrência é da ordem de 3\%. É o caso dos indivíduos 35, 36, 39, 40 e 41;

- para o aconselhamento genético do Caso 85, com embriopatia diabética, o risco é de 2 a 3 vezes maior para anomalias congênitas, do que o observado em filhos de mães não diabéticas. 
REFERÊNCIAS BIBLIOGRÁFICAS 


\section{REFERÊNCIAS BIBLIOGRÁFICAS}

Aase JM. Diagnostic dysmorphology. New York and London: Plenum Medical Book Company; 1990.

Ahmad NN, Ala-Kokko L, Knowlton RG, Jimenez SA, Weaver EJ, Maguire JI et al. Stop codon in the procollagen II gene (COL2A1) in a family with the Stickler syndrome (arthro-ophthalmopathy). Proc Natl Acad Sci U S A 1991; 88:6624-7.

Ahmed ZM, Riazuddin S, Riazuddin S, Wilcox ER. The molecular genetics of Usher syndrome. Clin Genet 2003; 63: 431-444.

Al-Fifi S, Teebi AS, Shevell M. Autosomal dominant Russell-Silver syndrome. Am $J$ Med Genet 1996; 61:96-7.

Alonso P, Pintos G, Almazan F, Hernández L, Loran E, Menchon JM et al. Eating disorder in a patient with phenotypical features of Lujan-Fryns syndrome. Clin Dysmorphol 2006; 15:181-4.

Amatuzzi MG, Northrop C, Bento RF, Eavey RD. Bases histológicas da perda auditiva em recém-nascidos de alto risco. Arq Otorrinolaringol 2005; 9:213-9.

Amor DJ, Delatycki MB, Gardner RJ, Storey E. New variant of familial cerebellar ataxia with hypergonadotropic hypogonadism and sensorineural deafness. Am J Med Genet 2001; 99:29-33.

Annunen S, Korkko J, Czarny M, Warman ML, Brunner HG, Kaariainen $\mathrm{H}$ et al. Splicing mutations of 54-bp exons in the COL11A1 gene cause Marshall syndrome, but other mutations cause overlapping Marshall/Stickler phenotypes. Am J Hum Genet 1999; 65: 974-83. 
Anton E, Blanco J, Egozcue J, Vidal F. Risk assessment and segregation analysis in a pericentric inversion inv6p23q25 carrier using FISH on decondensed sperm nuclei. Cytogenet Genome Res 2002; 97:149-54.

Aramaki M, Udaka T, Kosaki R, Makita Y, Okamoto N, Yoshihashi H et al. Phenotypic spectrum of CHARGE syndrome with CHD7 mutations. J Pediatr 2006; 148:410-4.

Arn PH, Mankinen C, Jabs EW. Mild mandibulofacial dysostosis in a child with a deletion of 3p. Am J Med Genet 1993; 46:534-6.

Avellan L. On aetiological factors in hypospadias. Scand J Plast Reconstr Surg 1977; $11: 115-23$.

Aymé S, Philip N. Fine-Lubinsky syndrome: a fourth patient with brachycephaly, deafness, cataract, microstomia and mental retardation. Clin Dysmorph 1996; 5: 55-60.

Bahuau M, Laurendeau I, Pelet A, Assouline B, Lamireau T, Taine L et al. Tandem duplication within the neurofibromatosis type 1 gene (NF1) and reciprocal $\mathrm{t}(15 ; 16)(\mathrm{q} 26.3 ; \mathrm{q} 12.1)$ translocation in familial association of NF1 with intestinal neuronal dysplasia type B (IND B). J Med Genet 2000; 37:146-50.

Balestrazzi P, Baeteman MA, Mattei MG, Mattei JF. Franceschetti syndrome in a child with a de novo balanced translocation $(5 ; 13)(\mathrm{q} 11 ; \mathrm{p} 11)$ and significant decrease of hexosaminidase B. Hum Genet 1983; 64:305-8.

Barrow LL, van Bokhoven H, Daack-Hirsch S, Andersen T, van Beersum SE, Gorlin R et al. Analysis of the p63 gene in classical EEC syndrome, related syndromes, and nonsyndromic orofacial clefts. J Med Genet 2002; 39:559-66.

Becerra JE, Khoury MJ, Cordero JF, Erickson JD. Diabetes mellitus during pregnancy and the risks for specific birth defects: a population-based case-control study. Pediatrics 1990; 85:1-9. 
Beckman A, Conway GS, Cadge B. Audiological features of Turner's syndrome in adults. Int J Audiol 2004; 43:533-44.

Bento RF. Surdez sensorioneural profunda. Diagn Tratam 1996; 2:12-13.

Bluestone CD, Stool SE. Pediatric Otolaringology, $2^{\text {nd }}$ ed. Philadelphia: WB Saunders Company; 1990.

Chakravarti A, Jain M. Rubella prevalence and its transmission in children. Indian $J$ Pathol Microbiol 2006; 49:54-6.

Chang EH, Menezes M, Meyer NC, Cucci RA, Vervoort VS, Schwartz CE et al. Branchio-oto-renal syndrome: the mutation spectrum in EYA1 and its phenotypic consequences. Hum Mutat 2004; 23:582-9.

Chen CP, Tzen CY, Chang TY, Lin CJ, Wang W, Lee CC et al. Prenatal diagnosis of de novo mosaic distal $18 \mathrm{q}$ deletion associated with congenital anomalies. Ultrasound Obstet Gynecol 2003; 21:202-4.

Chess S. Follow-up report on autism in congenital rubella. J Autism Child Schizophr 1977; 7:69-81.

Chun K, Teebi AS, Jung JH, Kennedy S, Laframboise R, Meschino WS et al. Genetic analysis of patients with the Saethre-Chotzen phenotype. Am J Med Genet 2002; 110 : 136-43.

Church MW, Abel EL. Fetal alcohol syndrome. Hearing, speech, language, and vestibular disorders. Obstet Gynecol Clin North Am 1998; 25:85-97.

Church MW, Eldis F, Blakley BW, Bawle EV. Hearing, language, speech, vestibular, and dentofacial disorders in fetal alcohol syndrome. Alcohol Clin Exp Res 1997; 21:227-37. 
Church MW, Gerkin KP. Hearing disorders in children with fetal alcohol syndrome: findings from case reports. Pediatrics 1988; 82:147-54.

Cohen MM Jr, Gorlin RJ. Epidemiology, etiology and genetic patterns. In: Gorlin RJ, Toriello HV, Cohen MM Jr, editors. Hereditary hearing loss and its syndromes. Oxford: Oxford University Press; 1995. p. 9-21.

Cohen MM Jr. The child with multiple birth defects. 2.ed. New York: Oxford University Press; 1997.

Cohen MM Jr. The process of syndrome delineation and the heterogeneity of hearing loss. Ann N Y Acad Sci 1991; 630:133-42.

Cormier_Daire V, Iserin L, Theophile D, Sidi D, Vervel C, Padovani JP et al. Upper limb malformations in DiGeorge syndrome. Am J Med Genet 1995; 56:39-41.

Cryns K, Van Camp G. Deafness genes and their diagnostic applications. Audiol Neuro otol 2004; 9:2-22.

da Silva EO. Callosal defect, microcephaly, severe mental retardation, and other anomalies in three sibs. Am J Med Genet 1988; 29:837-43.

Dabir TA, Morrison PJ. Trisomy 10p with clinical features of facio-auriculo-vertebral spectrum: a case report. Clin Dysmorphol 2006;15:25-7.

Danziger I, Brodsky L, Perry R, Nusbaum S, Bernat J, Robinson L. Nager's acrofacial dysostosis. Case report and review of the literature. Int $J$ Pediatr Otorhinolaryngol 1990; 20:225-40.

Davenport SLH, Omenn GS. The heterogeneity of Usher syndrome. (Abstract) Vth Int Conf on Birth Defect, Montreal, 8/1977. 
de Hoog M, van Zanten BA, Hop WC, Overbosch E, Weisglas-Kuperus N, van den Anker JN. Newborn hearing screening: tobramycin and vancomycin are not risk factors for hearing loss. $J$ Pediatr 2003; 142:41-6.

de Ravel TJ, Legius E, Brems H, Van Hoestenberghe R, Gillis PH, Fryns JP.

Hemifacial microsomia in two patients further supporting chromosomal mosaicism as a causative factor. Clin Dysmorphol 2001; 10:263-7.

Deng WP, Huang YS, Lu C, Lan W, Zhu GX, Lin OD et al. A novel KIT gene mutation from a family with piebaldism in the southern part of China. Zhonghua Yi Xue Yi Chuan Xue Za Zhi 2005; 22:668-70.

Dias O, Andrea M. Childhood deafness in Portugal - Aetiological factors and diagnosis of hearing loss. Int J Pediatr Otorhinol 1990; 18:247-55.

Digilio MC, Pacifico C, Tieri L, Marino B, Giannotti A, Dallapiccola B. Audiological findings in patients with microdeletion 22q11 (di George/velocardiofacial syndrome). Br J Audiol 1999; 33:329-33.

Dourmishev AL, Dourmishev LA, Schwartz RA, Janniger CK. Waardenburg syndrome. Int J Dermatol 1999; 38:656-63.

Duckett DP, Roberts SH. A new pericentric inversion of chromosome 6 in na abnormal infant. Ann Génét 1980; 23:117-118.

Duncan PA, Hall JG, Shapiro LR, Vibert BK. Three-generation dominant transmission of the Silver-Russell syndrome. Am J Med Genet 1990; 35:245-50.

Dupont J-M, Cuisset L, Cartigny M, Le Tessier D, Vasseur C, Rabineau D et al. Familial reciprocal translocation $\mathrm{t}(7 ; 16)$ associated with maternal uniparental disomy 7 in a Silver-Russell patient. Am J Med Genet 2002; 111:405-8. 
Eavey RD, Pinto LE, Thornton AR, Herrmann BS, do Carmo Bertero M, Saenz A. Early hearing testing of still critically ill neonates. Arch Otolaryngol Head Neck Surg 1996; 122:289-93.

Eggerding FA, Schonberg SA, Chehab FF, Norton ME, Cox VA, Epstein CJ. Uniparental isodisomy for paternal $7 \mathrm{p}$ and maternal $7 \mathrm{q}$ in a child with growth retardation. Am J Hum Genet 1994; 55:253-65.

El Ghouzzi V, Legeai-Mallet L, Benoist-Lasselin C, Lajeunie E, Renier D, Munnich A et al. Mutations in the basic domain and the loop-helix II junction of TWIST abolish DNA binding in Saethre-Chotzen syndrome. FEBS Lett. 2001; 492:112-8.

Elango S, Reddy TN, Shriwas SR. Ocular abnormalities in children from a Malaysian school for the deaf. Ann Trop Paediatr 1994;14:149-52.

Elango S. Actiology of deafness in children from a school for the deaf in Malaysia. Int $J$ Pediatr Otorhinolaryngol 1993; 27:21-7.

Ellwood LC, Winter ST, Dar H. Familial microtia with meatal atresia in two sibships. $J$ Med Genet 1968; 5:289-91.

Elsheikh M, Dunger DB, Conway GS, Wass JA. Turner's syndrome in adulthood. Endocr Rev 2002; 23:120-40.

Emanuel BS, Budarf ML, Sellinger B, Goldmuntz E, Driscoll DA. Detection of microdeletions of 22q11.2 with fluorescence in situ hybridization (FISH): diagnosis of DiGeorge syndrome (DGS), velo-cardio-facial (VCF) syndrome, CHARGE association and conotruncal cardiac malformations. (Abstract) Am J Hum Genet 1992; 51 (suppl.): A3 only.

Ensink RJ, Marres HA, Brunner HG, Cremers CW. Hearing loss in the Saethre-Chotzen syndrome. J Laryngol Otol 1996; 110:952-7. 
Ewart-Toland A, Yankowitz J, Winder A, Imagire R, Cox VA, Aylsworth AS et al. Oculoauriculovertebral abnormalities in children of diabetic mothers. Am J Med Genet 2000; 90:303-9.

Falkert A, Dittmann K, Seelbach-Gobel B. Silver-Russell syndrome as a cause for early intrauterine growth restriction. Prenat Diagn 2005; 25:497-501.

Feingold M, Bossert WH. apud Normal standards. In: Smith DW. Recognizable of human malformation. Genetic, embriologic and clinical aspects. 2 ed. W.B. Saunders Company. Philadelphia. London. Toronto, 1976. p. 451-472.

Fernandez L, Lapunzina P, Lopez Pajares I, Rodriguez Criado G, Garcia-Guereta L, Perez $\mathrm{J}$ et al. Higher frequency of uncommon 1.5-2 Mb deletions found in familial cases of 22q11.2 deletion syndrome. Am J Med Genet 2005; 136A:71-5.

Filippi G. Unusual facial appearance, microcephaly, growth and mental retardation, and syndactyly: a new syndrome? Am J Med Genet 1985; 22:821-4.

Fine BA, Lubinsky M. Craniofacial and CNS anomalies with body asymmetry, severe retardation, and other malformations. J Clin Dysmorph 1983; 1:6-9.

Fiumara, A.; Sorge, G.; Toscano, A.; Parano, E.; Pavone, L.; Opitz, J. M. : Perrault syndrome: evidence for progressive nervous system involvement. Am J Med Genet 2004; 128A: 246-249.

Ford LC, Sulprizio SL, Rasgon BM. Otolaryngological manifestations of velocardiofacial syndrome: a retrospective review of 35 patients. Laryngoscope 2000; 110:362-7.

Fox JE, Heimler A, Hershey JE, Crespi P. Sensorineural hearing loss, enamel hypoplasia, and nail defects: a new syndrome? (Abstract) Am J Hum Genet 1989; 45 (suppl.): A45 only. 
Franceschini P, Licata D, Guala A, Di Cara G, Franceschini D. Filippi syndrome: a specific MCA/MR complex within the spectrum of so called "craniodigital syndromes". Report of an additional patient with a peculiar MPP and review of the literature. Genet Counsel 2002; 13:343-52.

Fraser GR. The causes of profound deafness in childhood. Baltimore: Johns Hopkins University Press; 1976.

Freire-Maia N. Genetic loads in man. Hum Hered 1976; 26:95-104.

Friedman TB, Schultz JM, Ben-Yosef T, Pryor SP, Lagziel A, Fisher RA, Wilcox ER, Riazuddin S, Ahmed ZM, Belyantseva IA, Griffith AJ. Recent advances in the understanding of syndromic forms of hearing loss. Ear \& Hearing 2003; 24:289-302.

Friedman JM, Hanson JW, Graham CB, Smith DW. Saethre-Chotzen syndrome: a broad and variable pattern of skeletal malformation. J Pediatr 1977; 91:929-33.

Fuhrmann K, Reiher H, Semmler K, Fischer F, Fischer M, Glockner E. Prevention of congenital malformations in infants of insulin-dependent diabetic mothers. Diabetes Care 1983; 6:219-23.

Garry VF, Schreinemachers D, Harkins ME, Griffith J. Pesticide Appliers, biocides and birth defects in rural Minnesota. Environ Health Perspect 1996; 104:394-9.

Gernet H. Hereditaere Opticusatrophie in Kombination mit Taubheit. Dtsch Ophthal Ges 1964; 65: 545-547.

Gorlin RJ, Cohen MM Jr, Hennekam RCM, editors. Syndromes of the head and neck, $4^{\text {th }}$ ed. New York: Oxford University Press; 2001.

Gorlin RJ, Toriello HV, Cohen Junior MM, editors. Hereditary hearing loss and its syndromes, $1^{\text {st }}$ ed. New York: Oxford University Press; 1995. 
Gorlin RJ. Genetic hearing loss - a brief history. In: Gorlin RJ, Toriello HV, Cohen Junior MM, editors. Hereditary hearing loss and its syndromes, $1^{\text {st }}$ ed. New York: Oxford University Press; 1995 p. 3-4.

Gottschalk ME, Cocker SB, Fox LA. Neurologic anomalies of Perrault syndrome. Am J Med Genet 1996; 65:274-6.

Grellet M, Granzotti JA, Rocha KW, Motonaga SM. Surdez na rubéola congênita: aspectos audiológicos, oftalmológicos e cardíacos. Rev Bras Otorrinolaringol 1995; 164-70.

Griffith AJ, Sprunger LK, Sirko-Osadsa DA, Tiller GE, Meisler MH, Warman ML. Marshall syndrome associated with a splicing defect at the COL11A1 locus. Am J Hum Genet 1998; 62:816-23.

Grix A Jr. Malformations in infants of diabetic mothers. Am J Med Genet 1982; 13:1317.

Guala A, Germinetti V, Sebastiani F, Silengo MC. A syndrome of progressive sensorineural deafness and cataract inherited as an autosomal dominant trait. Clin Genet $1992 ; 41: 293-5$.

Guizar-Vazquez J, Arredondo-Vega F, Rostenberg I, Manzano C, Armendares S. Microtia and meatal atresia in mother and son. Clin Genet 1978; 14: 80-2.

Gupta A, Patton MA. Familial microtia with meatal atresia and conductive deafness in five generations. Am J Med Genet 1995; 59:238-41.

Hakami RM, Hou L, Baxter LL, Loftus SK, Southard-Smith EM, Incao A et al.Genetic evidence does not support direct regulation of EDNRB by SOX10 in migratory neural crest and the melanocyte lineage. Mech Dev 2006; 123:124-34. 
Halal F, Herrmann J, Pallister PD, Opitz JM, Desgranges MF, Grenier G. Differential diagnosis of Nager acrofacial dysostosis syndrome: report of four patients with Nager syndrome and discussion of other related syndromes. Am J Med Genet 1983; 14:209-24.

Hall BD. Nager acrofacial dysostosis: autosomal dominant inheritance in mild to moderately affected mother and lethally affected phocomelic son. Am J Med Genet $1989 ; 33: 394-7$.

Hall BD. The state of the art of dysmorphology. Am J Dis Child 1993; 147:1184-9.

Hanauer A, Young ID. Coffin-Lowry syndrome: clinical and molecular features. $J$ Med Genet 2002; 39:705-13.

Hanke W, Hausman K. Reproduction disorders in women occupationally exposed to pesticides. Med $\operatorname{Pr} 2000 ;$ 51:257-68.

Hathout EH, Elmendorf E, Bartley J. Hemifacial microsomia and abnormal chromosome 22. Am J Med Genet 1998; 76:71-3.

Heimler A, Fox JE, Hershey JE, Crespi P. Sensorineural hearing loss, enamel hypoplasia, and nail abnormalities in sibs. Am J Med Genet 1991; 39:192-5.

Heron D, Billette de Villemeur T, Munnich A, Lyonnet S. Filippi syndrome: a new case with skeletal abnormalities. J Med Genet 1995; 32:659-61.

Herrera JN, Huidobro MG, Ovalle LC. Malformaciones congénitas en hijos de madres con diabetes gestacional. Rev Méd Chile 2005; 133:547-54.

Higashi K, Matsuki C. Coffin-Lowry syndrome with sensorineural deafness and labyrinthine anomaly. J Laryngol Otol 1994; 108:147-8. 
Hone SW, Smith RJH. Genetics of hearing loss impairment. Semin Neonatol 2001; 6:531-541.

Hunter AGW. Coffin-Lowry syndrome: a 20-year follow-up and review of long-term outcomes. Am J Med Genet 2002; 111:345-55.

Hurst JA, Houlston RS, Roberts A, Gould SJ, Tingey WG. Transverse limb deficiency, facial clefting and hypoxic renal damage: an association with treatment of maternal hypertension? Clin Dysmorphol 1995; 4:359-63.

Instructions for contributors: Pedigree symbols. Am J Med Genet 2000; 90:90-3.

Jayarajan V, Swan IR, Patton MA. Hearing impairment in 18q deletion syndrome. J Laryngol Otol 2000; 114:963-6.

Joint Committee on Infant Hearing. Joint Committee on Infant Hearing 1994 position statement. ASHA 1994; 36:38-41.

Joint Committee on Infant Hearing. Joint Committee on Infant Hearing 2000 position statement.Pediatrics 2000; 106:798-817.

Kaiser P. Pericentric inversions. Problems and significance for clinical genetics. Hum Genet. 1984; 68:1-47.

Kalatzis V, Petit C. Branchio-otic syndromes imbroglio. Am J Med Genet 1999; 82:4401.

Karaman A, Aliagaoglu C. Waardenburg syndrome type 1. Dermatol Online J 2006; $12: 21$.

Kasprzak L, Der Kaloustian VM, Elliot AM, Shevell M, Lejtenyi C, Eydoux P. Deletion of 22q11 in two brothers with different phenotype. Am J Med Genet 1998; 75:288-91. 
Kawashima H, Tsuji N. Syndrome of microcephaly, deafness/malformed ears, mental retardation and peculiar facies in a mother and son. Clin Genet 1987; 31:303-307.

Kaye CI, Rollnick BR, Hauck WW, Martin AO, Richtsmeier JT, Nagatoshi K. Microtia and associated anomalies: statistical analysis. Am J Med Genet 1989; 34:574-8.

Kerketta L, Rao VB, Madkaiker M, Ghosh K, Mohanty D, Jijina F. Biphenotypic expression in a case of acute leukemia with pericentric inv(6)(p12q24). Cancer Genet Cytogenet 2005;159:187-9.

Klein D. Historical background and evidence for dominant inheritance of the KleinWaardenburg syndrome (type III). Am J Med Genet 1983; 14:231-9.

Kohlhase J, Heinrich M, Liebers M, Frohlich Archangelo L, Reardon W, Kispert A. Cloning and expression analysis of SALL4, the murine homologue of the gene mutated in Okihiro syndrome. Cytogenet Genome Res 2002; 98:274-7.

Kohlhase J, Wischermann A, Reichenbach H, Froster U, Engel W. Mutations in the SALL1 putative transcription factor gene cause Townes-Brocks syndrome. Nat Genet 1998; 18:81-3.

Kokitsu-Nakata NM, Guion-Almeida ML, Richieri-Costa A. Clinical genetic study of 144 patients with nonsyndromic hearing loss. Am J Audiol 2004; 13:99-103.

Konigsmark BM, Gorlin RJ. Genetic and metabolic deafness. W.B. Saunders, Philadelphia; 1976.

Konigsmark BW, Nager GT, Haskins HL. Recessive microtia, meatal atresia, and hearing loss. Report of a sibship. Arch Otolaryngol 1972; 96:105-9.

Kountakis SE, Skoulas I, Phillips D, Chang CY. Risk factors for hearing loss in neonates: a prospective study. Am J Otolaryngol 2002; 23:133-7. 
Kress W, Schropp C, Lieb G, Petersen B, Busse-Ratzka M, Kunz J et al. SaethreChotzen syndrome caused by TWIST 1 gene mutations: functional differentiation from Muenke coronal synostosis syndrome. Eur J Hum Genet 2006; 14:39-48.

Kress W, Schropp C, Lieb G, Petersen B, Busse-Ratzka M, Kunz J. Saethre-Chotzen syndrome caused by TWIST1 gene mutations: functional differentiation from Muenke coronal synostosis syndrome. Europ J Hum Genet 2006; 14:39-48.

Kristensen P, Irgens LM, Andersen A, Snelligen Bye A, Sundheim L. Birth defects among offspring of Norwegian farmers, 1967-1991. Epidemiology 1997; 8:537-44.

Kubota T, Wakui K, Nakamura T, Ohashi H, Watanabe Y, Yoshino M et al. The proportion of cells with functional $\mathrm{X}$ disomy is associated with the severity of mental retardation in mosaic ring X Turner syndrome females. Cytogenet Genome Res 2002; 99:276-84.

Kumar S, Deffenbacher K, marres HA, Cremers CW, Kimberling WJ. Genomewide search and genetic localization of a second gene associated with autosomal dominant branchio-oto-renal syndrome: clinical and genetic implications. Am J Hum Genet 2000; 66:1715-20.

Kumar S, Marres HAM, Cremers CWRJ, Kimberling WJ. Autosomal-dominant branchio-otic (BO) syndrome is not allelic to the branchio-oto-renal (BOR) gene at 8q13. Am J Med Genet 1998; 76:395-401.

Lalani SR, Safiullah AM, Fernbach SD, Harutyunyan KG, Thaller C, Peterson LE et al. Spectrum of CHD7 mutations in 110 individuals with CHARGE syndrome and genotype-phenotype correlation. Am J Hum Genet 2006; 78:303-14.

Larsen WJ. Human embryology. New York: Churchil Livingstone; 1993. 
LDDB, London dysmorphology data base [CD-ROM]. Baraitser M, Winter RM. Oxford University Press. Londres: Oxford Medical Data Base; 1996.

Leana-Cox J, Pangkanon S, Eanet KR, Curtin MS, Wulfsberg EA. Familial DiGeorge/velocardiofacial syndrome with deletions of chromosome area 22q11.2: report of five families with a review of the literature. Am J Med Genet 1996; 65:309-16.

Lee S, Seto M, Sie K, Cunningham M. A child with Saethre-Chotzen syndrome, sensorineural hearing loss, and a TWIST mutation. Cleft Palate Craniofac J 2002; 39:110-4.

Li C, Kosmorsky G, Zhang K, Katz BJ, Ge J, Traboulsi EI. Optic atrophy and sensorineural hearing loss in a family caused by an R445H OPA1 mutation. Am J Med Genet 2005; 138A: 208-11.

Libbey JE, Sweeten TL, McMahon WM, Fujinami RS. Autistic disorder and viral infections. J Neurovirol 2005; 11:1-10.

Liberfarb RM, Levy HP, Peter SR, Wilkin DJ, Davis J, Balog JZ et al. The Stickler syndrome: genotype/phenotype correlation in 10 families with Stickler syndrome resulting from 7 mutations in the type II collagen gene locus COL2A1. Genet Med $2003 ; 5: 21-27$.

Lindsay EA, Baldini A. Recovery from arterial growth delay reduces penetrance of cardiovascular defects in mice deleted for the DiGeorge syndrome region. Hum Molec Genet 2001; 10:997-1002.

Linssen WH, Van den Bent MJ, Brunner HG, Poels PJ. Deafness, sensory neuropathy, and ovarian dysgenesis: a new syndrome or a broader spectrum of Perrault syndrome? Am J Med Genet 1994; 51:81-2. 
Lopes VLGS. A malformação frontonasal: aspectos patogênicos, etiológicos, clínicos e diagnóstico diferencial [dissertação]. Campinas: Universidade Estadual de Campinas; 1995.

Lowry RB. The Nager syndrome (acrofacial dysostosis): evidence for autosomal dominant inheritance. Birth Defects Orig Art Ser XIII(3C) 1977; 195-220.

Lubianca Neto JF, Pereira AC. O que há de novo no campo da genética molecular da surdez: descoberta de genes para surdez. Rev Bras Otorrinolaringol 1999; 65: 106-13.

Lungarotti MS, Marinelli D, Mariani T, Calabro A. Multiple congenital anomalies associated with apparently normal maternal intake of vitamin A: a phenocopy of the isotretinoin syndrome? Am J Med Genet 1987; 27:245-8.

Marden PM, Smith DW, McDonald MJ. Congenital anomalies in the newborn infant, including minor variations: a study of 4,412 babies by surface examination for anomalies and buccal smear for sex chromatin. J Pediat 1964; 64:357-71.

Markie D, Huson S, Maher E, Davies A, Tomlinson I, Bodmer WE. A pericentric inversion of chromosome six in a patient with Peutz-Jeghers' syndrome and the use of FISH to localise the breakpoints on a genetic map. Hum Genet 1996; 98:125-8.

Marres HA. Hearing loss in the Treacher-Collins syndrome. Adv Otorhinolaryngol 2002; 61:209-15.

Marszalek B, Wojcicki P, Kobus K, Trzeciak WH. Clinical features, treatment and genetic background of Treacher Collins syndrome. J Appl Genet 2002; 43:223-33.

Martin S, Richards AJ, Yates JR, Scott JD, Pope M, Snead MP. Stickler syndrome: further mutations in COL11A1 and evidence for additional locus heterogeneity. Eur $J$ Hum Genet 1999; 7:807-14. 
Martinez-Frias ML. Epidemiological analysis of outcomes of pregnancy in diabetic mothers: identification of the most characteristic and most frequent congenital anomalies. Am J Med Genet 1994; 51:108-13.

Matteucci F, Tarantino E, Bianchi MC, Cingolani C, Fattori B, Nacci A et al. Sensorineural deafness, hydrocephalus and structural brain abnormalities in two sisters: the Chudley-McCullough syndrome. Am J Med Genet A 2006; 140:1183-8.

McDonald MT, Gorski JL. Nager acrofacial dysostosis. J Med Genet 1993; 30:779-82.

McDonald-McGinn DM, Kirschner R, Gldmuntz E, Sullivan K, Eicher P, Gerdes M et al. The Philadelphia story: the 22q11.2 deletion: report on 250 patients. Genet Couns $1999 ; 10: 11-24$.

Mckusick VA. Mendelian inheritance in man, v. 1. 10th Edn, Baltimore, London: The John Hopkins University Press; 1992.

Meinecke P. Short stature, microcephaly, characteristic face, syndactyly and mental retardation: the Filippi syndrome: report on a second family. Genet Counseling 1993; 4: 147-51.

Meurman Y. Congenital microtia and meatal atresia: observations and aspects of treatment. Arch Otolaryngol 1957; 66:443-63.

Meyerson MD, Nisbet JB. Nager syndrome: an update of speech and hearing characteristics. Cleft Palate J 1987; 24:142-51.

Midro AT, Debek K, Sawicka A, Marcinkiewicz D, Rogowska M. Second observation of Silver-Russel syndrome in a carrier of a reciprocal translocation with one breakpoint at site 17q25. (Letter) Clin Genet 1993; 44:53-5. 
Miller E, Cradock-Watson JE, Pollock TM. Consequences of confirmed maternal rubella at successive stages of pregnancy. Lancet 1982; 2:781-4.

Mills JL. Malformations in infants of diabetic mothers. Teratology 1982; 25:385-94.

Ming JE, McDonald-McGinn DM, Megerian TE, Driscoll DA, Elias ER, Russell BM et al. Skeletal anomalies and deformities in patients with deletions of $22 \mathrm{q} 11$. Am J Med Genet 1997; 72:210-5.

Moeschler J, Clarren SK. Familial occurrence of hemifacial microsomia with radial limb defects. Am J Med Genet 1982; 12:371-5.

Monk D, Bentley L, Hitchins M, Myler RA, Clayton-Smith J, Ismail S et al. Chromosome $7 \mathrm{p}$ disruptions in Silver Russell syndrome: delineating an imprinted candidate gene region. Hum Genet 2002; 111:376-87.

Nakane T, Mizobe N, Hayashibe H, Nakazawa S. A variant of Fine-Lubinsky syndrome: a Japanese boy with profound deafness, cataracts, mental retardation, and brachycephaly without craniosynostosis. Clin Dysmorphol 2002; 11:195-8.

Nance WE. The genetics of deafness. Ment Retard Dev Disabil Res Rev 2003; 9:109-19.

Naritomi K, Tohma T, Goya Y, Shiroma N, Hirayama K. Delineation of the da-Silva syndrome. Am J Med Genet 1994; 49:313-6.

Nellhaus G. apud Normal Standards. In: Smith DW. Recognizable patterns of human malformation. Genetic, embriologic and clinical aspects. 2 ed. W.B. Saunders Company. Philadelphia. London. Toronto. 1976. p. 451-472.

Niemann-Seyde SC, Eber SW, Zoll B. Saethre-Chotzen syndrome (ACS III) in four generations. Clin Genet 1991; 40:271-6. 
Nishi Y, Hamamoto K, Kajiyama M, Kawamura I.The Perrault syndrome: clinical report and review. Am J Med Genet 1988; 31:623-9.

Nishimura G, Haga N, Kitoh H, Tanaka Y, Sonoda T, Kitamura M et al. The phenotypic spectrum of COL2A1 mutations. Hum Mutat 2005; 26:36-43.

North KN, Wu BL, Cao BN, Whiteman DAH, Korf BR. CHARGE association in a child with de novo inverted duplication (14)(q22-q24.3). Am J Med Genet 1995; 57:610-614.

Northern JL, Downs MP. Audição em crianças. 3 ed. São Paulo: Manole; 1989. p. 2553.

Nuijten I, Admiraal R, Van Buggenhout G, Cremers C, Frijns JP, Smeets D et al. Congenital aural atresia in $18 \mathrm{q}$ deletion or de Grouchy syndrome. Otol Neurotol 2003; 24:900-6.

Nurminen T, Rantala K, Kurppa K, Holmberg PC. Agricultural work during pregnancy and selected structural malformations in Finland. Epidemiology 1995; 6:23-30.

Nussbaum RL, McInnes RR, Willard HF. Thompson \& Thompson - Genética médica. Rio de Janeiro: Editora Guanabara Koogan S.A.; 2002.

Oliveira CA, Pinheiro LC, Gomes MR. External and middle ear malformations: autosomal dominant genetic transmission. Ann Otol Rhinol Laryngol 1989; 98:772-6.

Online Mendelian Inheritance in Man, OMIM (TM). McKusick-Nathans Institute for Genetic Medicine, Johns Hopkins University (Baltimore, MD) and National Center for Biotechnology Information, National Library of Medicine (Bethesda, MD), 2000. World Wide Web URL: http://www.ncbi.nlm.nih.gov/omim/ 
Orstavik KH, Medbo S, Mair IWS. Right-sided microtia and conductive hearing loss with variable expressivity in three generations. Clin Genet 1990; 38:117-20.

Orye E, Craen M. Partial long-arm deletion of chromosome 8 (pter $\rightarrow \mathrm{q} 13:: \mathrm{q} 22 \rightarrow \mathrm{qter})$ without Langer-Giedion syndrome. Ann Génét 1983; 26:44-6.

Oskarsdottir S, Vujic M, Fasth A. Incidence and prevalence of the 22q11 deletion syndrome: a population-based study in Western Sweden. Arch Dis Child 2004; 89:14851.

Ostberg JE, Conway GS. Adulthood in women with Turner syndrome. Horm Res 2003; 59:211-21.

Ostergaard E, Pedersen VF, Skriver EB, Brondum-Nielsen K. Brothers with ChudleyMcCullough syndrome: sensorineural deafness, agenesis of the corpus callosum, and other structural brain abnormalities. Am J Med Genet A 2004; 124:74-8.

Ounap K, Reimand T, Magi ML, Bartsch O. Two sisters with Silver-Russell phenotype. Am J Med Genet A. 2004; 131:301-6.

Pallister PD, Opitz JM. The Perrault syndrome: autosomal recessive ovarian dysgenesis with facultative, non-sex-limited sensorineural deafness. Am J Med Genet 1979; 4:23946.

Parving A. Aetiological diagnosis in hearing-impaired children - clinical value application of a modern examination programme. Int J Pediatr Otorhinol 1984; 7:2938.

Parving A. Congenital hearing disability - epidemiology and identification: a comparison between two health authority districts. Int J Pediatr Otorhinol 1993; 27: 29-46. 
Passos-Bueno MR, Wilcox WR, Jabs EW, Sertie AL, Alonso LG, Kitoh H. Clinical spectrum of fibroblast growth factor receptor mutations. Hum Mutat 1999;14:115-25.

Payne M, Yang Z, Katz BJ, Warner JEA, Weight CJ, Zhao Y et al. Dominant optic atrophy, sensorineural hearing loss, ptosis, and ophthalmoplegia: a syndrome caused by a missense mutation in OPA1. Am J Ophthal 2004; 138: 749-55.

Paznekas WA, Cunningham ML, Howard TD, Korf BR, Lipson MH, Grix AW et al. Genetic heterogeneity of Saethre-Chotzen syndrome, due to TWIST and FGFR mutations. Am J Hum Genet 1998; 62:1370-80.

Pettenati MJ, Rao PN, Phelan MC, Grass F, Rao KW, Cosper P et al. Paracentric inversions in humans: a review of 446 paracentric inversions with presentation of 120 new cases. Am J Med Genet 1995; 55:171-87.

Pollak C, Floy M, Say B. Sensorineural hearing loss and enamel hypoplasia with subtle nail findings: another family with Heimler's syndrome. Clin Dysmorph 2003; 12: 55-8.

POSSUM: Pictures of Standard Syndromes and Undiagnosed Malformations. Melbourne: Murdock Institute for Researched into Birth Defects, 1998.

Poulson AV, Hooymans JM, Richards AJ, Bearcroft P, Murthy R, Baguley DM et al. Clinical features of type 2 Stickler syndrome. J Med Genet 2004; 41:107.

Prasad C, Quackenbush EJ, Whiteman D, Korf B. Limb anomalies in DiGeorge and CHARGE syndromes. Am J Med Genet 1997; 68:179-81.

Preus M, Cooper AR, O'Leary E. Sensorineural hearing loss, small facial features, submucous cleft palate, and myoclonic seizures. J Clin Dysmorph 1984; 2:30-1.

Preus M, Linstrom C, Polomeno RC, Milot J. Waardenburg syndrome-penetrance of major signs. Am J Med Genet 1983; 15:383-8. 
Price SM, Stanhope R, Garrett C, Preece MA, Trembath RC. The spectrum of SilverRussell syndrome: a clinical and molecular genetic study and new diagnostic criteria. $J$ Med Genet 1999; 36: 837-42.

Purandare KN, Markar TN. Psychiatric symptomatology of Lujan_fryns syndrome: an X-linked syndrome displaying Marfanoid symptoms with autistic features, hyperactivity, shyness and schizophreniform symptoms. Psychiatric Genetics 2005; $15: 229-31$.

Purandare KN, Markar TN. Psychiatric symptomatology of Lujan-Fryns syndrome: an X-linked syndrome displaying Marfanoid symptoms with autistic features, hyperactivity, shyness and schizophreniform symptoms. Psychiatr Genet 2005; 15:22931.

Ravnan JB, Chen E, Golabi M, Lebo RV. Chromosome 22q11.2 microdeletions in velocardiofacial syndrome patients with widely variable manifestations. Am $\mathrm{J} \mathrm{Med}$ Genet 1996; 66:250-6.

Reardon W, Wilkes D, Rutland P, Pulleyn LJ, Malcolm S, Dean JC et al. Craniosynostosis associated with FGFR3 pro250arg mutation results in a range of clinical presentations including unisutural sporadic craniosynostosis. J Med Genet 1997; 34:632-6.

Regenbogen L, Godel V. Ocular deficiencies in deaf children. J Pediatr Ophthalmol Strabismus 1985; 22:231-3.

Ribeiro EM, Sugayama SMM, Utagawa CY, Kim CA, Leone CR, Gonzales CH. Malformações congênitas em filhos de mães diabéticas: relato de casos. Pediatria 1997; 19:65-75.

Rice DP, Aberg T, Chan Y, Tang Z, Kettunen PJ, Pakarinen L et al. Integration of FGF and TWIST in calvarial bone and suture development. Development 2000; 127:1845-55. 
Richieri-Costa A, Bortolozo MA, Lauris RC, Guion-Almeida ML, Marques D, Moreti D. Mandibulofacial dysostosis: report on two Brazilian families suggesting autosomal recessive inheritance. Am J Med Genet 1993; 46:659-64.

Rickard S, Boxer M, Trompeter R, Bitner-Glindzicz M. Importance of clinical evaluation and molecular testing in the branchio-oto-renal (BOR) syndrome and overlapping phenotypes. (Letter) J Med Genet 2000; 37:623-7.

Rodini ES, Richieri-Costa A. EEC syndrome: report on 20 new patients, clinical and genetic considerations. Am J Med Genet 1990; 37:42-53.

Roelfsema NM, Cobben JM. The EEC syndrome: a literature study. Clin Dysmorphol $1996 ; 5: 115-27$.

Rosanowski F, Hoppe U, Proschel U, Eysholdt U. Late-onset sensorineural hearing loss in Coffin-Lowry syndrome. ORL J Otorhinolaryngol Relat Spec 1998; 60:224-6.

Roush J, Davenport ML, Carlson-Smith C. Early-onset sensorineural hearing loss in a child with Turner syndrome. J Am Acad Audiol 2000; 11:446-53.

Ruf RG, Berkman J, Wolf MT, Nurnberg P, Gattas M, Ruf EM et al. A gene locus for branchio-otic syndrome maps to chromosome 14q21.3-q24.3. J Med Genet 2003; 40:515-9.

Sanchez-Corona J, Garcia-Cruz D, Ruenes R, Cantu JM. A distinct dominant form of microtia and conductive hearing loss. Birth Defects Orig Artic Ser 1982; 18:211-6.

Sanchez-Martin M, Perez-Losada J, Rodriguez-Garcia A, Gonzalez-Sanchez B, Korf BR, Kuster W et al. Deletion of the SLUG (SNAI2) gene results in human piebaldism. Am J Med Genet 2003; 122A:125-32. 
Sassada MMY, Ceccon MEJ, Navarro JM, Vaz FAC. Deficiência auditiva em recémnascidos internados em unidade de terapia intensiva neonatal. Pediatria 2005; 27:16371.

Schaub RL, Hale DE, Rose SR, Leach RJ, Cody JD. The spectrum of thyroid abnormalities in individuals with 18q deletions. J Clin Endocrinol Metab 2005; 90:2259-63.

Schmid M, Schroder M, Langenbeck U. Familial microtia, meatal atresia, and conductive deafness in three siblings. Am J Med Genet 1985; 22:327-32.

Senrui H. Congenital clasped thumb combined with Waardenburg syndrome in three generations of one family: an undescribed congenital anomalies complex. $J$ Pediatr Orthop 1984; 4:472-6.

Shalev SA, Dar H, Barel H, Borochowitz Z. Upper limb malformations in chromosome 22q11 deletions. Am J Med Genet 1996; 62:302.

Sharif S, Donnai D. Filippi syndrome: two cases with ectodermal features, expanding the phenotype. Clin Dysmorph 2004; 13:221-6.

Shaw GM, Wasserman CR, O'malley CD, Nelson V, Jackson RJ. Maternal pesticide exposure from multiple sources and selected congenital anomalies. Epidemiology 1999; 10:60-6.

Sheffer R, Zlotogora J. Autosomal dominant inheritance of Klein-Waardenburg syndrome. Am J Med Genet 1992; 42:320-2.

Shimizu S, Mori N, Kishi M, Sugata H, Tsuda A, Kubota N. A novel mutation in the OPA1 gene in a Japanese patient with optic atrophy. Am J Ophthal 2003; 135: 256-7. 
Snead MP, Yates JR. Clinical and Molecular genetics of Stickler syndrome. J Med Genet 1999; 36:353-9.

Sood R, Bader PI, Speer MC, Edwards YH, Eddings EM, Blair RT et al. Cloning and characterization of an inversion breakpoint at 6q23.3 suggests a role for Map7 in sacral dysgenesis. Cytogenet Genome Res 2004;106:61-7.

Souza LCA. Diagnóstico precoce da surdez infantil e estratégias terapêuticas. $J$ Pediatr 1995; 71:96-100.

Splendore A, Silva EO, Alonso LG, Richieri-Costa A, Alonso N, Rosa A et al. High mutation detection rate in TCOF1 among Treacher Collins syndrome patients reveals clustering of mutations and 16 novel pathogenic changes. Hum Mutat 2000; 16:315-22.

Spranger J, Benirschke K, Hall JG, Lenz W, Lowry RB, Opitz JM, Pinsky L, Schwarzacher HG, Smith DW. Errors of morphogenesis: concepts and terms. J Pediatr 1982; 100:160-5.

Spritz RA, Beighton P. Piebaldism with deafness: molecular evidence for an expanded syndrome. Am J Med Genet 1998; 75:101-3.

Stathopulu E, Mackie Ogilvie C, Flinter FA. Terminal deletion of chromosome $5 p$ in a patient with phenotypical features of Lujan-Fryns syndrome. Am J Med Genet 2003; 119A:363-6.

Stickler GB, Belau PG, Farrell FJ, Jones JD, Pugh DG, Steinberg AG et al. Hereditary progressive arthro-ophthalmopathy. Mayo Clin Proc 1965; 40: 433-55.

Stickler GB, Hughes W, Houchin P. Clinical features of hereditary progressive arthroophthalmopathy (Stickler syndrome): a survey. Genet Med 2001; 3:192-6. 
Strisciuglio P, Ballabio A, Parenti G. Microtia with meatal atresia and conductive deafness: mild and severe manifestations within the same sibship. J Med Genet 1986; 23:459-60.

Stromland K, Pinazo-Durán MD. Ophthalmic involvement in the fetal alcohol syndrome: clinical and animal model studies. Alcohol Alcohol 2002; 37:2-8.

Suthers GK, Earley AE, Huson SM. A distinctive syndrome of brachycephaly, deafness, cataracts and mental retardation. Clin Dysmorph 1993; 2:342-5.

Swillen A, Vogels A, Devriendt K, Fryns JP. Chromosome 22q11 deletion syndrome: update and review of the clinical features, cognitive-behavioral spectrum, and psychiatric complications. Am J Med Genet 2000; 97:128-35.

Tanner JM; Whitehouse RH apud Normal standards. Smith, DW. Recognizable patterns of human malformation. Genetic, embriologic and clinical aspects. 2 ed. W.B. Saunders Company. Philadelphia. London. Toronto. 1976. p. 451-72.

Teber OA, Gillessen-Kaesbach G, Fischer S, Bohringer S, Albrecht B, Albert A et al. Genotyping in 46 patients with tentative diagnosis of Treacher Collins syndrome revealed unexpected phenotypic variation. Europ J Hum Genet 2004; 12:879-90.

Tekin M, Bodurtha JN, Nance WE, Pandya A. Waardenburg syndrome type 3 (KleinWaardenburg syndrome) segregating with a heterozygous deletion in the paired box domain of PAX3: a simple variant or a true syndrome? Clin Genet 2001; 60:301-4.

Tellier AL, Cormier-Daire V, Abadie V, Amiel J, Sigaudy S, Bonnet D et al. CHARGE syndrome: report of 47 cases and review. Am J Med Genet 1998; 76:402-409.

Terhal P, Rosler B, Kohlhase J. A family with features overlapping Okihiro syndrome, hemifacial microsomia and isolated Duane anomaly caused by a novel SALL4 mutation.Am J Med Genet 2006; 140:222-6. 
Thomas JA, Graham JM Jr. Chromosomes 22q11 deletion syndrome: an update and review for the primary pediatrician. Clin Pediatr (Phila) 1997; 36:253-66.

Tischkowitz M, Clenaghan C, Davies S. Amelogenesis imperfecta, sensorineural hearing loss, and Beau's lines: a second case report of Heimler's syndrome. J Med Genet 1999; 36: 941-3.

Titomanlio L, Romano A, Conti A, Genesio R, Salerno M, de Brasi D et al. Mild WolfHirschhorn phenotype and partial GH deficiency in a patient with a $4 p$ terminal deletion. Am J Med Genet 2004; 127:197-200.

Tomita Y, Suzuki T. Genetics of pigmentary disorders. Am J Med Genet C Semin Med Genet 2004;131C:75-81.

Toriello HV, Higgins JV, Abrahamson J, Waterman DF, Moore WD. X-linked syndrome of branchial arch and other defects. Am J Med Genet 1985; 21:137-42.

Toriello HV, Higgins JV. Craniodigital syndromes: report of a child with Filippi syndrome and discussion of differential diagnosis. Am J Med Genet 1995; 55:200-4.

Van Camp G, Smith R. Hereditary hearing loss homepage. [online] 2006 July 16. Disponível: URL: http://webhost.ua.ac.be/hhh/

Van Rijin PM, Cremers CW. Causes of childhood deafness at a Dutch school for hearing - impaired. Ann Otol Rhinol Laryngol 1991; 100:903-8.

Vendramini S. Avaliação genética-clínica e audiológica de indivíduos com anomalias de $1^{\circ}$ e $2^{\circ}$ arcos branquiais associadas à anomalia radial [dissertação]. Bauru: Universidade de São Paulo; 2006. 
Versacci P, Digilio MC, Sauer U, Dallapiccola B, Marino B. Absent pulmonary valve with intact ventricular septum and patent ductus arteriosus: a specific cardiac phenotype associated with deletion 18q syndrome. Am J Med Genet 2005; 138:185-6.

Vikkula M, Mariman EC, Lui VC, Zhidkova NI, Tiller GE, Goldring MB et al. Autosomal dominant and recessive osteochondrodysplasias associated with the COL11A2 locus. Cell 1995; 80:431-7.

Wang R, Martinez-Frias ML, Graham JM Jr. Infants of diabetic mothers are at increased risk for the oculo-auriculo-vertebral sequence: A case-based and case-control approach. J Pediatr 2002; 141:611-7.

Warkany J. Syndromes. Am J Dis Child 1971; 121(5):365-70.

Wenstrom KD, Muilenburg AC, Patil SR, Hanson JW. Unique phenotype associated with a pericentric inversion of chromosome 6 in three generations. Am J Med Genet. 1991; 39:102-5.

Wieczorek D, Krause M, Majewski F, Albrecht B, Horn D, Riess O et al. Effect of the size of the deletion and clinical manifestation in Wolf-Hirschhorn syndrome: analysis of 13 patients with a de novo deletion. Eur J Hum Genet 2000; 8:519-26.

Wildervanck LS. Perceptive deafness associated with split-hand and -foot, a new syndrome? Acta Genet Stat Med 1963; 13:161-9.

Williams MS, Williams JL, Wargowski DS, Pauli RM, Pletcher BA. Filippi syndrome: report of three additional cases. Am J Med Genet 1999; 87:128-33.

Wilson DI, Burn J, Scambler P, Goodship J. DiGeorge syndrome, part of CATCH 22. J Med Genet 1993; 30:852-6. 
Wittine LM, Josephson KD, Williams MS. Aortic root dilation in apparent Lujan-Fryns syndrome. Am J Med Genet 1999; 86:405-9.

Wollmann HA, Kirchner T, Enders H, Preece MA, Ranke MB. Growth and symptoms in Silver-Russell syndrome: review on the basis of 386 patients. Eur J Pediatr 1995; 154:958-68.

Wollnik B, Tukel T, Uyguner O, Ghanbari A, Kayserili H, Emiroglu $\mathrm{M}$ et al. Homozygous and heterozygous inheritance of PAX3 mutations causes different types of Waardenburg syndrome. Am J Med Genet 2003; 122:42-5.

Woods CG, Crouchman M, Huson SM. Three sibs with phalangeal anomalies, microcephaly, severe mental retardation, and neurological abnormalities. J Med Genet $1992 ; 29: 500-2$.

World Health Organization. Prevention of blindness and deafness. [online][consultado 07 jul 2006] Disponível: URL: http://www.who.int/pbd/deafness/hearing_impairment_grades/en/index.html

Wright TJ, Clemens M, Quarrell O, Altherr MR. Wolf-Hirschhorn and Pitt-RogersDanks syndromes caused by overlapping 4p deletions. Am J Med Genet 1998; 75:34550 .

Yoon PJ, Price M, Gallagher K, Fleisher BE, Messner AH. The need for long-term audiologic follow-up of neonatal intensive care unit (NICU) graduates. Int J Pediatr Otorhinolaryngol 2003; 67:353-7.

Zankl M, Zang KD. Inheritance of microtia and aural atresia in a family with five affected members. Clin Genet 1979; 16: 331-4. 
Zechi-Ceide RM. Estudo genético-clínico e molecular em portadores de síndrome de Stickler. Análise do gene COL2A1 [tese]. Botucatu: Universidade Estadual Paulista "Júlio de Mesquita Filho"; 2005.

Zollino M, Lecce R, Fischetto R, Murdolo M, Faravelli F, Selicorni A et al. Mapping the Wolf-Hirschhorn syndrome phenotype outside the currently accepted WHS critical region and defining a new critical region, WHSCR-2. Am J Hum Genet 2003; 72:590-7. 
GLOSSÁRIO 


\section{GLOSSÁRIO}

Aconselhamento genético: é o processo de comunicação que visa, especialmente, orientar casais sobre a ocorrência ou risco de recorrência de uma doença genética em descendentes, e fornecer-lhes informações pertinentes, expostas de forma simples, sincera e direta.

Agenesia: ausência de uma parte do corpo, devido à ausência do primórdio embrionário.

Amelogênese imperfeita: variedade de alterações genéticas que afetam a formação do esmalte dentário e não estão associadas a efeitos sistêmicos.

Amenorréia: ausência de menstruação.

Anomalia congênita: anormalidade estrutural presente ao nascimento (malformações primárias, secundárias e deformações)

Apêndice: qualquer anexo, geralmente de importância secundária.

Aplasia: ausência de uma parte do corpo devido às falhas de desenvolvimento do primórdio embrionário. Conceitualmente, as agenesias são malformações primárias e, as aplasias, malformações secundárias.

Associação: ocorrência não casual, em dois ou mais indivíduos, de múltiplas anomalias, não reconhecidas como defeito politópico de campo, seqüência ou síndrome.

Atresia: imperfuração ou oclusão de uma abertura ou canal normal.

Atrofia: diminuição do volume da massa de um tecido ou órgão normalmente desenvolvido, decorrente da diminuição do tamanho celular e/ou do número de células.

Autossomo: qualquer cromossomo nuclear que não seja os cromossomos sexuais; 22 pares no cariótipo humano. Uma doença causada pela mutação em um gene autossômico, ou par de genes, apresenta herança autossômica.

Braquicefalia: sinostose bilateral da sutura coronal que causa um achatamento da região posterior do crânio.

Braquidactilia: dígitos ou artelhos curtos.

Campos de desenvolvimento: representam unidades do embrião nas quais o desenvolvimento de estruturas complexas é determinada e controlada de uma maneira espacialmente coordenada, temporalmente sincrônica e hierarquicamente epimórfica.

Camptodactilia: estado em que um ou mais dígitos se apresentam, constantemente, fletidos em uma ou em ambas as articulações falângicas.

Cariótipo: a constituição cromossômica de um indivíduo.

Caso isolado: um indivíduo que é o único membro de sua família afetado por um distúrbio genético, seja por acaso ou por uma nova mutação.

Clinodactilia: defeito congênito que consiste no encurvamento anormal lateral dos dígitos ou artelhos.

Coloboma: qualquer falha congênita, patológica ou cirúrgica, especialmente nos olhos (pálpebras, íris, corpo ciliar, coróide, nervo óptico).

Congênito: presente ao nascimento, mas não, necessariamente, genético. 
Consangüíneos: relacionados, por descendência, de um ancestral comum.

Craniosinostose: oclusão prematura das suturas de ossos cranianos, observada, geralmente, ao nascer ou pouco depois , ou devido à hipocalcemia idiopática. A conformação da cabeça e a ausência ou presença de sintomas dependem das estruturas atingidas.

Criptorquidia: defeito do desenvolvimento no qual os testículos ficam retidos no interior do abdômen ou do canal inguinal, deixando de descer para a bolsa escrotal.

Cromossomo: uma das estruturas filamentares do núcleo da célula. Consiste em cromatina e carrega a informação genética (DNA).

Defeito de redução: termo amplo, que se refere a todas as anomalias de membros em que haja agenesia ou hipoplasia de qualquer segmento.

Deficiência: comprometimento de determinada função.

Deformação: forma ou posição anormal de uma parte do corpo causada por forças mecânicas. Estas forças podem ser extrínsecas (compressão uterina) ou intrínsecas (mobilidade fetal diminuída por defeito do sistema nervoso) ao feto. As deformações podem resultar também de causas malformativas ou funcionais e surgem, mais freqüentemente, durante a vida fetal tardia.

Deleção: a perda de uma seqüência de DNA de um cromossomo. O DNA deletado pode ser de qualquer tamanho, desde uma só base, até uma grande parte do cromossomo.

Deletéria: prejudicial, lesivo.

Disacusia: distúrbio na audição, expresso em qualidade e não em intensidade sonora. O aumento da intensidade da fonte sonora não garante o perfeito entendimento do significado das palavras.

Disgenesia gonadal: gônadas constituídas somente por estroma do tipo ovariano e tecido fibroso, quase sempre sem capacidade de produção de hormônios e gametas, determinando ausência de desenvolvimento puberal, amenorréia primária e esterilidade. Algumas pacientes apresentam função ovariana residual e desenvolvimento puberal espontâneo, podendo menstruar e até mesmo serem férteis.

Dismorfia: deformidade; forma anormal.

Displasia: defeito na histogênese, processo que ocorre nos estágios tardios da morfogênese e que se estende pela vida fetal e pós-fetal; desenvolvimento ou crescimento anormal, especialmente de células.

Disrupção: defeito morfológico de um órgão, parte de um órgão ou ampla região do corpo, resultante de um desarranjo ou interferência no processo de desenvolvimento de um primórdio originalmente normal. Fatores extrínsecos como infecções, teratógenos ou trauma podem interferir no desenvolvimento de um primórdio inicialmente normal.

Dystopia canthorum ou telecanto: aumento da distância intercantal ocular interna, acompanhado pelo distanciamento dos pontos lacrimais inferiores, com preservação das medidas da distância interpupilar e intercantal ocular externa.

Dominante: uma característica é dominante, se for fenotipicamente expressa nos heterozigotos.

Ectrodactilia: ausência parcial de dígitos ou artelhos.

Ectrópio: eversão da pálpebra inferior.

Epicanto: prega cutânea medial e inferior da pálpebra superior que encobre o canto interno e a carúncula; característica normal em certos grupos asiáticos. 
Epidemiologia: ciência que estuda o processo saúde-doença na comunidade, analisando a distribuição e os fatores determinantes das enfermidades e dos agravos à saúde coletiva, sugerindo medidas específicas de prevenção, de controle ou de erradicação.

Esporádica: em genética médica, uma doença causada por uma nova mutação.

Expressividade: a extensão na qual se expressa um defeito genético. Se houver uma expressividade variável, a característica poderá variar em expressão, de branda a grave, mas nunca será completamente não-expressa nas pessoas que tiverem o genótipo correspondente.

Familial: qualquer característica que seja mais comum nos parentes de uma pessoa afetada, do que na população em geral, seja a causa genética, ambiental ou ambas.

Fenótipo: as características bioquímicas, fisiológicas e morfológicas observadas de um indivíduo, determinadas por seu genótipo e o ambiente o qual se expressa.

FISH (hibridização in situ com fluorescência): mapeamento de um gene por hibridização molecular de uma seqüência de DNA clonado, marcada por radioatividade ou fluorescência, em uma dispersão cromossômica ou núcleo celular em uma lâmina.

Gene: uma unidade hereditária; em termos moleculares, uma seqüência de DNA que é necessária para a produção de um produto funcional.

Gene candidato: aquele cujo produto tem propriedades bioquímicas ou outras que sugiram que ele possa ser comprovado como sendo o gene procurado como responsável por certa doença.

Genótipo: a constituição genética de uma pessoa, distinta pelo fenótipo; mais especificamente, os alelos presentes em um locus.

Glossoptose: posteriorização da língua.

Hemangioma: tumor hamartomatoso composto de vasos sangüíneos ou linfáticos.

Heredograma (pedigree): em genética médica, uma história familiar em condição hereditária; um diagrama de uma história familiar, indicando os membros familiares, seu parentesco com o probando e sua condição com relação a uma determinada condição hereditária.

Heterocromia: condição na qual, as duas íris são de cor diferente ou, uma porção de uma íris é de cor diferente do restante.

Heterogeneidade clínica: ocorrência de fenótipos clinicamente diferentes, por mutações no mesmo gene.

Heterogeneidade genética: produção do mesmo fenótipo, ou de fenótipos similares, por mecanismos genéticos diferentes.

Hiperplasia: hiperdesenvolvimento de um órgão ou tecido, devido ao aumento do número de células.

Hipertelorismo: aumento da distância entre dois órgãos ou partes do corpo.

Hipoacusia: redução na sensitividade da audição, sem qualquer alteração da qualidade da mesma. O aumento da intensidade da fonte sonora possibilita uma audição bastante adequada.

Hipocromia: deficiência ou falta de cor.

Hipoplasia: hipodesenvolvimento de um órgão ou tecido, devido à diminuição do número de células.

Hipospadia: anomalia congênita do pênis e da uretra, a qual se abre na superfície ventral do pênis no períneo. 
Hipotonia: diminuição da tonicidade muscular.

Hipotrofia: diminuição do tamanho de células, tecidos ou órgãos.

Hipertrofia: aumento do tamanho de células, tecidos ou órgãos.

Hirsutismo: desenvolvimento de pilosidade excessiva.

Inversão: rearranjo cromossômico, no qual um segmento de um cromossomo é revertido de ponta a ponta. Se o centrômero estiver incluído na inversão, ela é pericêntrica; caso não, é paracêntrica.

Luxação: deslocamento, especialmente de articulações.

Macrocefalia: estado caracterizado por cabeça grande, cujo perímetro cefálico é maior do que dois desvios padrão acima da média, para a idade e o sexo.

Malar: referente à bochecha ou ao zigoma.

Malformação primária (malformação propriamente dita): defeito morfológico de um órgão, parte de um órgão ou região ampla do corpo, resultante de um processo de desenvolvimento intrinsicamente anormal do desenvolvimento embrionário.

Malformação secundária (disrupção): defeito morfológico de um órgão, parte de um órgão ou região ampla do corpo, resultante de um colapso ou de uma interferência sobre um processo de desenvolvimento originalmente normal.

Menarca: primeiro fluxo menstrual.

Microcefalia: estado caracterizado por cabeça pequena, cujo perímetro cefálico é menor do que dois desvios padrão abaixo da média, para a idade e o sexo.

Microftalmia: estado em que o globo ocular é anormalmente pequeno.

Micrognatia: tamanho anormalmente pequeno do maxilar inferior.

Microtia: consiste desde uma orelha pequena até uma orelha rudimentar.

Monossomia: constituição cromossômica, na qual um membro de um par cromossômico está ausente.

Mosaico: um indivíduo ou tecido com, pelo menos, duas linhagens celulares que diferem em genótipo ou cariótipo, derivadas de um único zigoto.

Mutação: qualquer alteração herdável permanente na seqüência do DNA genômico.

Nevo (nevus): qualquer lesão que contém melanócitos.

Nistagmo: movimento oscilatório dos globos oculares.

Oligodactilia (ou hipodactilia): ausência total de algum (alguns) dos dígitos ou artelhos.

PCR (reação em cadeia da polimerase): técnica de genética molecular pela qual uma seqüência curta de DNA ou RNA é muito amplificada por meio de dois primers oligonucleotídicos flanqueadores, usados em ciclos repetidos de ampliação dos primers e síntese de DNA pela DNA polimerase.

Penetrância: a fração de indivíduos com um genótipo conhecido, como causador de uma doença, que têm alguns sinais ou sintomas dessa doença.

Politelia: presença de mamilos supranumerários. 
Propósito (ou probando): o membro afetado da família, por meio do qual, a família é avaliada.

Ptose palpebral: anomalia que consiste na queda das pálpebras superiores, devido à inversão ausente ou incompleta dos músculos elevadores das pálpebras.

Rearranjo: quebra cromossômica, seguida de reconstituição em uma combinação anormal.

Recessiva: uma característica que é expressa apenas em homozigotos ou hemizigotos.

Retinose pigmentar: processo hereditário, que atinge todas as camadas da retina, resultando em atrofia lentamente progressiva de seus elementos nervosos, aglutinação do pigmento e, mais tarde, atenuação das arteríolas retinianas e atrofia cérea dos discos ópticos. Ocorre comprometimento da visão noturna, constrição dos campos visuais e eventual cegueira.

Risco de recorrência: a probabilidade de que um distúrbio genético, presente em um ou mais membros de uma família, recorra em outro membro da mesma geração ou de uma geração subseqüente.

Seqüência: padrão de múltiplas anomalias derivadas de uma única anomalia. Um defeito primário ou uma disrupção ou um fator mecânico pode originar uma cascata de alterações secundárias na morfogênese subseqüente.

Sindactilia: fusão cutânea e/ou óssea de dígitos ou artelhos.

Síndrome: padrão de múltiplas anomalias patogeneticamente relacionadas que não representam seqüência ou associação. O padrão de anomalias em uma síndrome pode se originar de vários campos de desenvolvimento.

Sinofre: presença anormal de pêlos entre as sobrancelhas.

Teratógeno: um agente que produz malformações ou aumenta sua incidência.

Translocação: transferência de segmento de um cromossomo para outro.

Translocação robertsoniana: translocação entre dois cromossomos acrocêntricos, por fusão no centrômero ou perto dele, com perda dos braços curtos.

Trigonocefalia: sinostose prematura da sutura metópica, resultando em fronte triangular.

Ungueal: referente às unhas. 


\section{ANEXO 1 - Termo de consentimento livre e esclarecido}

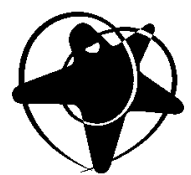

HOSPITAL dE REABILITACÃO DE ANOMALIAS CRANIOFACIAIS UNIVERSIDADE DE SAO PAULO

GENÉTICA CLÍNICA

\section{TERMO DE CONSENTIMENTO LIVRE E ESCLARECIDO}

\section{CARTA DE INFORMAÇÃO}

Este estudo denominado "Síndromes Genéticas e Ambientais em Distúrbios da Audição", tem como objetivo realizar avaliação genética-clínica de pacientes portadores de deficiência auditiva associada a outras anomalias, atendidas no Centro de Atendimento aos Distúrbios da Audição, Linguagem e Visão (CEDALVI) do HRAC-USP-Bauru, com o intuito de se realizar o diagnóstico de prováveis síndromes e prover meios para a realização do aconselhamento genético adequado. Para isto, será realizada avaliação física, preenchimento de protocolo específico, realização de exames subsidiários que se fizerem necessários (cariótipo, raios-X, tomografia de crânio e/ou osso temporal e outros) e de documentação fotográfica.

As atividades propostas não promovem riscos para o indivíduo avaliado e qualquer dúvida quanto aos procedimentos ou assuntos relacionados ao estudo serão esclarecidos.

Ressaltamos que a participação do indivíduo no estudo é inteiramente voluntária. A não aceitação em participar do mesmo, sem expor as razões, assim como, a desistência de sua participação, não o prejudicará.

Sua identidade será mantida em sigilo. As fotografias e informações obtidas no estudo poderão ser divulgadas em publicações e/ou eventos científicos.

\section{TERMO DE CONCORDÂNCIA}

$\mathrm{Eu}$ do $R G n^{\circ}$ $n^{o}$ menor , residente à Rua (Av.)

portador CEDALVI/HRAC-USP com o $\mathrm{n}^{\circ}$ Estado de , (responsável* pelo $(\mathrm{a})$ , matriculado (a) no "Síndromes Genéticas e Ambientais em Distúrbios da Audição", realizada por Nancy Mizue Kokitsu Nakata - CRB 04849-01, sob orientação da Profa. Dra. Maria Leine Guion de Almeida - CRM 30.253.

Declaro ter sido esclarecido (a) quanto ao objetivo da referida pesquisa e estou de acordo com os termos deste estudo. Autorizo, por meio deste, a realização das avaliações acima citadas e a divulgação científica dos resultados e documentação fotográfica, mantendo sempre a identidade do paciente em sigilo.

de

Bauru, de

Assinatura do Paciente (ou Responsável)*

* em caso de menor de idade ( $<21$ anos) 
ANEXO 2 - Ofício de aprovação pelo Comitê de Ética em Pesquisa 


\author{
ANEXO 3 - Protocolo de pesquisa \\ PROTOCOLO \\ SÍNDROMES GENÉTICAS E AMBIENTAIS EM DISTÚRBIOS DA COMUNIÇÃO
}

Data:

\title{
1. DADOS PESSOAIS
}

Nome:

Data de nascimento:

Naturalidade:

Escolaridade:

Pai:

Idade na concepção:

Profissão:

Mãe:

Idade na concepção:

Profissão:

Procedência:

\section{HISTÓRICO FAMILIAL}

Recorrência:

Consanguinidade:
RG:

Sexo: $\square \mathrm{M} \quad \square \mathrm{F}$

Naturalidade:

Naturalidade:

Heredograma

Gemelaridade: 


\section{DADOS GESTACIONAIS E PERINATAIS}

$\mathrm{G} \_\mathrm{P} \_\mathrm{A}$

\begin{tabular}{|c|c|c|}
\hline Aborto: & $\square \mathrm{N}$ & $\square \mathrm{AE}$ \\
\hline Intercorrê & $\square \mathrm{N}$ & $\square \mathrm{S}$ \\
\hline
\end{tabular}

Infecções materna:

$\square \mathrm{S}$

$\square \mathrm{CMV}$

$\square$ Lues

Oligoidrâmnio: $\square \mathrm{S}$

Diabetes:

$\square \mathrm{S}$

insulino-dependente:

$\square \mathrm{S}$

$\square \mathrm{N}$

$\square \mathrm{N}$

Uso de:

$\square$ Ácido retinóico

$\square$ Talidomida

\section{$\square \mathrm{N}$}

$\square$ Rubéola $\quad \square$ Toxoplasmose

$\square$ Herpes $\quad \square$ Outras:

$\square$ Anticonvulsivantes (especificar):

$\square$ Outros:

Parto: $\square$ Normal

$\square$ Cesáreo

$\square$ Fórceps

PN:

EN:

PCN:

Condições de nascimento:

Outras intercorrências perinatais:

\section{ANTECEDENTES PESSOAIS}

Sustentou pescoço:

Sentou sem apoio:

Engatinhou:

Andou sem apoio:

Primeiras palavras:

Formação sentenças: 
Escolaridade:

Uso de medicamentos: $\quad \square \mathrm{S} \quad \square \mathrm{N}$

Ototóxicos: $\quad \square \mathrm{S} \quad \square \mathrm{N}$

Quais ? Com que freqüência ? Com que idade ? Período ?

Infecções de ouvido:

$\square \mathrm{S}$

$\square \mathrm{N}$

Com que frequência?

Doenças:

$\begin{array}{ll}\square \text { Meningite } & \square \mathrm{S} \\ \square \text { Caxumba } & \square \text { Sarampo } \\ \square \text { Outras } & \square \text { Infecções de vias aéreas superiores }\end{array}$

Observações:

\section{AVALIAÇÃO CLÍNICA-GENÉTICA}

Idade:

$\begin{array}{lll}\text { P: } & \text { E/A: }\end{array}$

Outras medidas pertinentes:

5.1 Anomalias craniofaciais (especificar o lado)

Assimetria facial: $\square \mathrm{S} \quad \square \mathrm{N}$

Assimetria crânio: $\square \mathrm{S}$

Ramo e/ou côndilo mandibular hipoplásico: $\square \mathrm{S} \quad \square \mathrm{N}$

Ramo e/ou côndilo mandibular ausente: $\square \mathrm{S} \quad \square \mathrm{N}$

Hidrocefalia: $\square \mathrm{S} \quad \square \mathrm{N}$

Microcefalia: $\square \mathrm{S} \quad \square \mathrm{N}$

Encefalocele: $\square \mathrm{S} \quad \square$ occipital $\quad \square$ frontal

$\square \mathrm{N}$

Outras:

5.1.1 Anomalias oculares (especificar o lado)

$\begin{array}{lll}\square \text { Dermóide epibulbar } & \square \text { Coloboma palpebral } & \square \text { Anoftalmia } \\ \square \text { Microftalmia } & \square \text { Fenda palpebral estreita } & \square \text { Coloboma de retina }\end{array}$

$\square$ Outras: 


\subsubsection{Boca}

$\begin{array}{ll}\square \text { FL(P) } & \square \text { IVF } \\ \square \text { FP } & \square \text { Hipernasalidade } \\ \square \text { F mediana } & \square \text { Outros }\end{array}$

5.1.3 Anomalias auriculares (especificar o lado)

$\square$ Microtia - grau:

$\square$ Apêndices pré-auriculares

Fístula pré-auricular

$\square$ Apêndice entre tragus/boca

$\square$ DA

$\square$ Atresia de CAE

$\square$ Agenesia de CAE

$\square$ Hipoplasia de ossículos OM

$\square$ Agenesia de ossículos OM

Realizou tomografia de osso temporal $\square \mathrm{S} \quad \square$ Normal $\quad \square$ Alterada

$\square \mathrm{N}$

Outras:

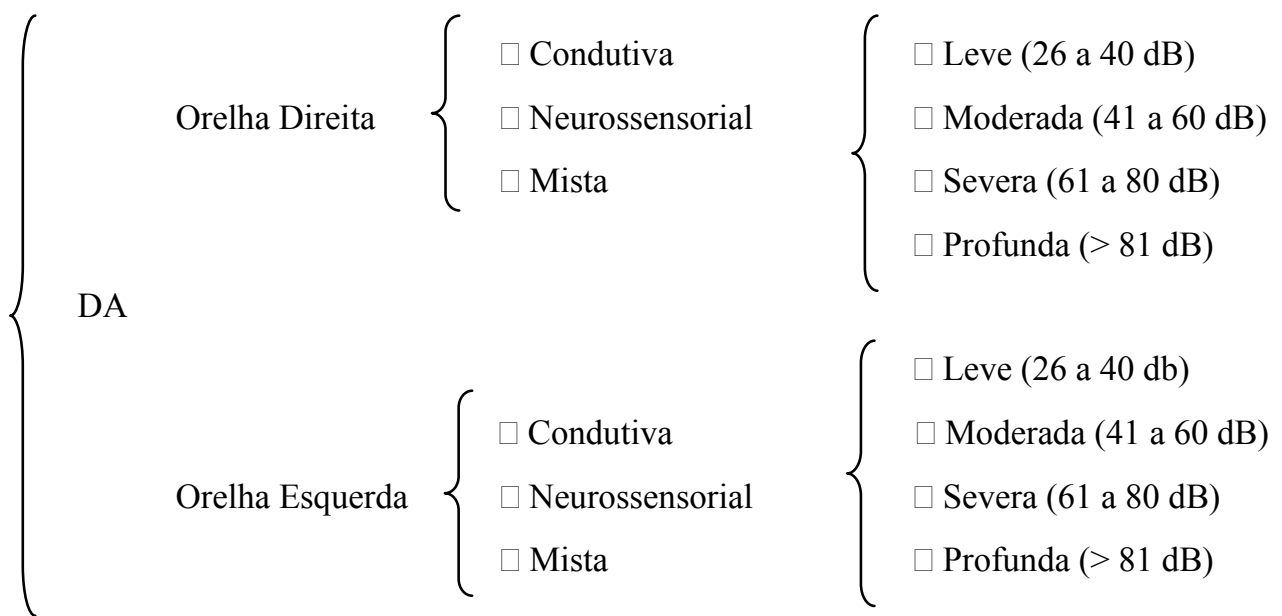

\subsection{Anomalias cardiovasculares}

$\square \mathrm{S} \quad \square \mathrm{N}$

$\square$ defeito de septo ventricular

$\square$ estenose pulmonar

$\square$ Outras:

\subsection{Anomalias pulmonares}

$\square \mathrm{S}$ $\square \mathrm{N}$

$\square$ agenesia de pulmão $\square$ hipoplasia de pulmão

Outras: 
5.4 Anomalias renais

$\square \mathrm{S} \quad \square \mathrm{N}$

$\square$ agenesia de rim

$\square$ Outras:

5.5 Anomalias esqueléticas (especificar)

$\square$ anomalia de costelas (agenesia/fusão/duplicação)

$\square$ defeito de redução

$\square$ fusão vértebras

$\square$ hemivértebra

$\square$ espinha bífida

$\square$ vértebras hipoplásicas

$\square$ escoliose

$\square$ pé torto

$\square$ hipoplasia de rádio e/ou polegar

$\checkmark$ agenesia de rádio e/ou polegar

$\square$ Outras:

$\square$ raio X coluna sem alterações

5.6 Outras anomalias (especificar)

6. RESUMO DOS SINAIS CLÍNICOS

\section{EXAMES SUBSIDIÁRIOS:}

Hipótese Diagnóstica:

\section{Conduta:}

\section{Retorno:}

